UNIVERSIDADE DE SÃO PAULO

FACULDADE DE DIREITO

ALVARO THEODOR HERMAN SALEM CAGGIANO

Tratamento das nulidades no processo administrativo

São Paulo

2013 


\section{Tratamento das nulidades no processo administrativo}

Dissertação de mestrado apresentada ao Departamento de Direito do Estado, para obtenção do título de Mestre em Direito.

Área de concentração: Direito do Estado - Direito Administrativo

Orientador: Professor Doutor Edmir Netto de Araújo 


\section{Serviço de Biblioteca e Documentação}

\section{Faculdade de Direito da Universidade de São Paulo}

\section{Caggiano, Alvaro Theodor Herman Salem.}

C133t Tratamento das nulidades no processo administrativo / Alvaro Theodor Herman Salem Caggiano. - - São Paulo: USP / Faculdade de Direito, 2013.

$194 \mathrm{f}$.

Orientador: Prof. Dr. Edmir Netto de Araújo. Dissertação (Mestrado), Universidade de São Paulo, USP, Programa de Pós-Graduação em Direito, 2013.

1. Processo Administrativo. 2. Nulidade. 3. Ato Administrativo. 4. Administração Pública (Princípios). I. Araújo, Edmir Netto de. II. Universidade de São Paulo, Faculdade de Direito, Programa de Pós-Graduação em Direito. III. Título. 
FOLHA DE APROVAÇÃO

Alvaro Theodor Herman Salem Caggiano

TRATAMENTO DAS NULIDADES NO PROCESSO ADMINISTRATIVO

Dissertação apresentada à Faculdade de Direito da Universidade de São Paulo para obtenção do título de Mestre em Direito.

Área de Concentração: Direito do estado - Direito Administrativo

Aprovado em:

Banca Examinadora

Prof. Dr. Edmir Netto de Araújo

Instituição:

Assinatura:

Prof. Dr.

Instituição: Assinatura:

Prof. Dr.

Instituição: Assinatura:

Prof. Dr.

Instituição: Assinatura:

Prof. Dr.

Instituição: Assinatura: 
“Fé inabalável é a única força que pode encarar a razão de igual para igual em qualquer época da humanidade."

Evangelho Segundo o Espiritismo - Allan Kardec 


\section{RESUMO}

CAGGIANO, Alvaro Theodor Herman Salem. Tratamento das nulidades no processo administrativo. 2013. 194 f. Dissertação (Mestrado) - Faculdade de Direito, Universidade de São Paulo, São Paulo, 2013.

Estreia, na Constituição Federal de 1988, de forma expressa, a incidência dos princípios da ampla defesa e do "due process" no processo administrativo, consagrando, pois, a presença efetiva do modelo Estado de Direito a emoldurar e balizar a atividade desenvolvida pelo Poder Público. Considerando, destarte, que o Estado atua não apenas por intermédio de atos administrativos isolados, mas também por via de processos, cada dia mais complexos, demandando um particular debruçar por parte dos analistas, pareceu-nos oportuno o estudo da incidência da teoria das nulidades em sede de processos administrativos. A perspectiva deste estudo, sem abandonar a teoria da invalidez dos atos administrativos, busca o aprofundamento no domínio da ocorrência de fatores que possam conduzir à nulidade e invalidade do processo administrativo - tanto geral, como disciplinar - perquirindo as condições necessárias para assegurar aos processos trâmites regulares, afastando os vícios e mantendo-os sempre no campo da legalidade. A perspectiva do trabalho, destarte, busca recolocar tema tão polêmico em debate e, sob a lente da investigação científica, apresentar, de modo sistematizado, as doutrinas, as teses desenvolvidas e a jurisprudência construída de modo a assegurar a evolução do tratamento jurídico oferecido ao processo administrativo para o efetivo atingimento de suas finalidades públicas. Ao administrado, de outro lado, a pesquisa se revela de interesse, porquanto põe à luz, evidenciando, os princípios pelos quais a Administração deve se pautar para que determinado ato seja válido e eficaz. Cuida-se de preservar a supremacia do interesse público, em prol dos objetivos fundamentais do standard do Estado Democrático de Direito, dentre eles, uma sociedade livre, justa e solidária.

Palavras-chave: Nulidades no processo administrativo. A aplicação dos princípios da boa fé e do devido processo legal nos processos administrativos brasileiros. A teoria da invalidação dos atos administrativos no Brasil. Os princípios que devem guiar a Administração Pública no Brasil. 


\begin{abstract}
CAGGIANO, Alvaro Theodor Herman Salem. The legal treatment of the nullities in administrative procedures. 2013. 194 f. Master Degree Report - Faculty of Law, University of São Paulo, 2013.

For the first time, the 1988 Brazilian Federal Constitution expressly provides for the application of the principles of fair hearing and due process of law to administrative procedures, thereby enshrining the tangible presence of the rule of law approach, whose purpose is to frame and limit the activities performed by the Government. Therefore, considering that the Government does not operate only through isolated administrative acts, but also through increasingly complex processes that require particular examination by analysts, it seems fitting to study the application of the theory of nullities in administrative procedures. Although it does not depart from the theory of invalidity of administrative acts, the focus of this study is to inquire into facts that may result in the nullity and invalidity of administrative procedures - both of a general and disciplinary nature - and establish the necessary conditions to ensure the regular course of procedure, thereby avoiding errors and preserving its legal integrity. Thus, this paper aims to rekindle the discussion on this controversial subject and, based on a scientific analysis, presents a systematized portrayal of the relevant doctrines, theses and case law that were produced with a view to the development of the legal framework that underpins administrative procedure and the fulfillment of its public mission. On the other hand, this research is of interest also to private individuals, as it brings to light the principles the Public Administration must observe for any given act to be considered valid and effective. Particular care is taken to preserve the paramount importance of public interest as a fundamental objective that determines the standards of a state founded on the rule of law, including a free, equal and fair society.
\end{abstract}

Key-words: Nullities in administrative procedures. The application of the principles of fair hearing and due process of law to brazilian administrative procedures. The theory of invalidity of administrative acts in Brazil. The principles that must guide the Public Administration in Brazil. 


\section{SUMÁRIO}

INTRODUÇÃO ........................................................................................... 10

CAPÍTULO I - DOS PRINCÍPIOS E REGRAS DE REGÊNCIA DO PROCESSO ADMINISTRATIVO ............................................................... 12

1.1 CONSIDERAÇÕES PRELIMINARES - A EVOLUÇÃO DA TEORIA DO PROCESSO NO DIREITO ADMINISTRATIVO _....................................................... 12

1.1.1 A emergência do Direito Administrativo ........................................................... 12

1.1.2 O fenômeno processual - A trajetória e a relevância em sede de Direito Administrativo ............................................................................................................................ 17

1.1.3 O processo administrativo na sua evolução em cenário brasileiro ....................... 21

1.2 O ESTADO DE DIREITO E SEUS COMANDOS ................................................... 23

1.3 PRINCÍPIOS E REGRAS ....................................................................................... 31

1.4 PRINCÍPIOS NO DIREITO ADMINISTRATIVO ............................................... 35

1.4.1 Princípios Informativos ................................................................................... 35

1.4.1.1 Princípio da supremacia do interesse público ......................................................... 35

1.4.1.2 Princípio da legalidade .................................................................................................. 37

1.4.2 Princípios Gerais ............................................................................................................. 41

1.4.2.1 Princípio da indisponibilidade do interesse público................................................. 41

1.4.2.2 Princípio do poder-dever ....................................................................................... 42

1.4.2.3Princípio da igualdade - isonomia ..................................................................................... 42

1.4.2.4 Princípio da impessoalidade......................................................................................... 43

1.4.2.5 Princípio da moralidade administrativa .................................................................. 44

1.4.2.6 Princípio da publicidade ................................................................................................. 45

1.4.2.7 Princípio da eficiência ......................................................................................... 47

1.4.2.8 Princípio da razoabilidade e proporcionalidade........................................................ 48

1.4.2.9 Princípio da responsabilidade do Estado........................................................... 50

1.4.2.10 Presunção de legitimidade, imperatividade e autoexecutoriedade ......................... 51

1.4.2.11 Princípio do controle jurisdicional ........................................................................ 52

1.4.2.12 Princípio da autotutela ............................................................................................. 53

1.4.2.13 Princípio da discricionariedade ............................................................................... 53

1.5 OS PRINCÍPIOS QUE REGEM O PROCESSO ADMINISTRATIVO ............... 55 
1.5.1 Princípio do Contraditório

1.5.2 Princípio da Ampla Defesa ......................................................................... 59

1.5.3 Princípio da Duração Razoável do processo ....................................................... 61

1.5.4 Princípio da Oficialidade ......................................................................................................... 63

1.5.5 Princípio da Verdade Material............................................................................. 65

1.5.6 Princípio do Informalismo ou Obediência às Formas e Procedimentos................ 69

1.6 O PROCESSO ADMINISTRATIVO SOB GARANTIA DO DUE PROCESS OF

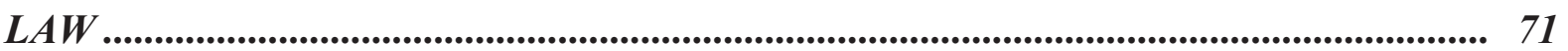

1.7 DA LEGISLAÇÃO DE REGÊNCIA DO PROCESSO ADMINISTRATIVO - AS TRÊS ESFERAS GOVERNAMENTAIS _......................................................... 82

1.7.1 A elaboração do anteprojeto de lei do processo administrativo federal - $O$ trabalho de criação da lei de regência ............................................................................................. 83

1.7.2 A Lei federal $n^{0}$ 9.784, de 29 de janeiro de 1999 - Lineamentos......................... 84

1.7.3 O Tratamento legal do processo administrativo no Estado de São Paulo - Lei

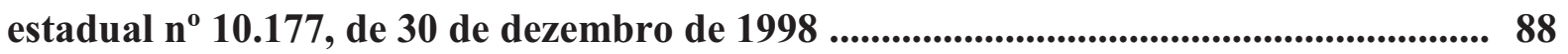

1.7.4 O Tratamento legal do processo administrativo no Município de São Paulo - Lei municipal $n^{0} 14.141$, de 27 de março de 2006 ................................................................ 91

1.8 DO PROCESSO ADMINISTRATIVO DISCIPLINAR - TRATAMENTO LEGAL

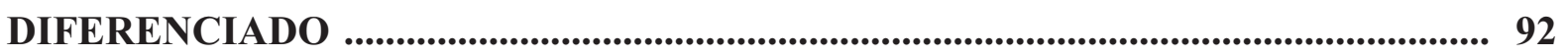

1.8.1 Regime jurídico-legal no âmbito da União, do Estado de São Paulo e do Município de São Paulo

CAPÍTULO II - DAS NULIDADES NO PROCESSO ADMINISTRATIVO.. 104 2.1 CONSIDERAÇÕES PRELIMINARES - O DEVER DE RECOMPOR A LEGALIDADE 104

2.2 O DESENVOLVIMENTO DA TEORIA DOS VÍCIOS NO DIREITO ADMINISTRATIVO. 109

2.3 NOÇÕES ATUAIS SOBRE A TEORIA DOS VÍCIOS NO DIREITO ADMINISTRATIVO ........................................................................................................ 122

2.4 TRATAMENTO DOS VÍCIOS NO PROCESSO ADMINISTRATIVO................. 128

2.5 DOS TIPOS DE VÍCIOS NO PROCESSO ADMINISTRATIVO ............................. 134

2.5.1 Ato administrativo processual inexistente .............................................................. 134

2.5.2 Ato administrativo processual irregular .......................................................... 139 
2.5.3 Ato administrativo processual anulável 141

2.5.4 Ato administrativo processual nulo 145

$\begin{array}{llllll}2.6 & \text { A NULIDADE } & \text { NO PROCESSO ADMINISTRATIVO } & \text { - } & \text { ATO }\end{array}$ ADMINISTRATIVO PROCESSUAL NULO E SUAS INCIDÊNCIAS

2.6.1 Nulidade relativa ao sujeito 147

2.6.2 Nulidade relativa à forma 153

2.6.3 Nulidade relativa ao objeto, motivo e finalidade 160

$\begin{array}{lllllll}2.7 & \text { EFEITOS DA DECLARAÇÃO DE NULIDADE NO PROCESSO }\end{array}$

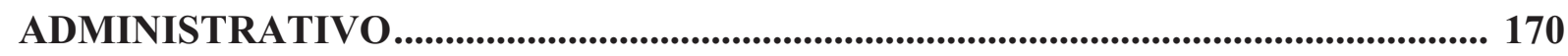

2.8 LIMITES DA DECLARAÇÃO DE NULIDADE NO PROCESSO

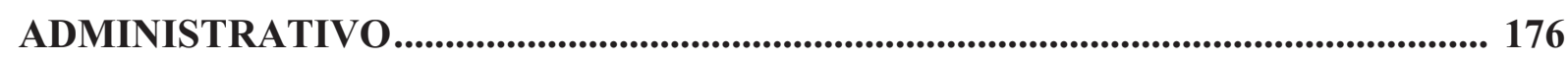

CONCLUSÕES

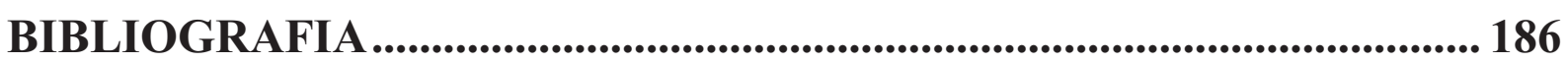




\section{INTRODUÇÃO}

A presente dissertação tem por finalidade investigar e desenvolver estudos sobre as nulidades no processo administrativo, tema instigante, polêmico, que demanda especial atenção, sobretudo considerando a atividade da Administração Pública em ambiente norteado pelo standard do Estado de Direito.

Neste contexto, o processo administrativo assume importante papel na consecução e no aprimoramento da democracia e do democrático funcionamento de suas instituições.

Nesta perspectiva, pretende-se perquirir a regular atuação da Administração, a sempre possível presença de ilegalidades a atingir o processo administrativo, e isso diante do poder-dever de que o Poder Público se encontra imbuído, no sentido de assegurar a legalidade da sua atuação, direcionada sempre ao atingimento do interesse público, certamente a sua base para o exercício das funções preconizadas pela nossa Magna Lei de 1988.

Não há que ignorar, nesta esteira, o período das monarquias absolutas, que marcou os séculos XV a XVIII, durante o qual o Governante, que acumulava em sua pessoa praticamente todas as funções estatais, valia-se do poder de imposição e editava ordens sem a mínima participação da comunidade, de eventuais interessados ou das partes.

No processo de tomada de decisão, estava ausente qualquer parâmetro ou preocupação com a legalidade, sendo esta uma marca desse período histórico, conflitante com os caracteres e exigências da atual sociedade contemporânea, que reclama pela ordem democrática plasmada pelo modelo do Estado de Direito.

O percurso evolutivo da sociedade, do ponto de vista político, econômico, social e jurídico, a partir do final do século XVIII e ao longo dos séculos XIX e XX, bem como o expandido papel que possui hodiernamente o Poder Executivo na consecução dos fins públicos, não só modificou aquele quadro como, ainda, passou a impor ao Poder Público uma atuação mais complexa, por intermédio de processos administrativos, estes, por vezes, demandando a participação de indivíduos ou da própria coletividade. Mais que isso, uma atuação dentro de parâmetros de legalidade, compatibilizando-se, pois, com a ordem jurídica em vigor.

Certo, no entanto, que, nesta senda, a atuação da Administração, por meio do processo ou não, pode vir a apresentar ilegalidades, considerando-se, sobretudo, a 
possibilidade de afronta não só às regras, como aos princípios que regem o Direito Administrativo.

Ademais, no que concerne ao processo administrativo, a ilegalidade da atuação da Administração pode decorrer, também, da violação aos axiomas que disciplinam específico campo.

Na presente dissertação, o objeto de análise são os processos administrativos geral e disciplinar - com atenção especial para o disposto na legislação editada no âmbito da União, do Estado de São Paulo e do Município de São Paulo.

Partindo do exame dos princípios e das regras que regem o Direito Administrativo, com foco no processo administrativo, a pesquisa segue para verificar o sistema de ilegalidades no Direito Administrativo pátrio, realizando-se, em certa medida, a transposição dessa teoria para o âmbito do processo administrativo.

O trabalho prossegue para não ignorar a questão pertinente à forma pela qual o sistema de ilegalidades, no campo do direito administrativo, atua no processo administrativo. E o enfoque recai sobre a análise das diferentes possibilidades de infiltração no processo administrativo de ilegalidades, vícios que o tornem defeituoso em diversos graus, de acordo com a gravidade. O panorama desta dissertação, pois, compreende as doutrinas elaboradas e o entendimento da jurisprudência construída sobre a matéria, discutindo o modus operandi de contaminação do processo administrativo, o efeito do vício sobre o campo processual, as soluções jurídicas propostas e a resolução dos efeitos produzidos pelas ilegalidades, inclusive com relação a terceiros. 


\section{DOS PRINCÍPIOS E REGRAS DE REGÊNCIA DO PROCESSO ADMINISTRATIVO}

\subsection{CONSIDERAÇÕES PRELIMINARES - A EVOLUÇÃO DA TEORIA DO PROCESSO NO DIREITO ADMINISTRATIVO}

\subsubsection{A emergência do Direito Administrativo}

A análise do presente tópico oferece relevância, uma vez que o Direito Administrativo é disciplina recente em comparação aos demais ramos do Direito, como o Direito Civil e Penal, sendo que o desenvolvimento do processo no Direito Administrativo não se realizou de forma desconectada da própria evolução da sociedade sob os principais enfoques, isto é, político, institucional, social, econômico e, principalmente, jurídico. Na sua trajetória, recebeu influência do Direito tanto dos países de origem romanística, quanto de origem anglo-saxã.

É importante registrar, também, que o percurso evolutivo do fenômeno processual, antes entendido como privativo da função atinente ao Poder Judiciário, atingiu a ideia da existência de um núcleo comum de processualidade, compreendendo elementos de presença obrigatória em quaisquer manifestações do processo, indiferentemente do conteúdo a que se refira e que se aprecie.

Assim, a análise do desenvolvimento da teoria processual no Direito Administrativo torna-se oportuna, no sentido de viabilizar o acompanhamento de sua evolução em países de origem romanística e anglo-saxã, bem como entender como o fenômeno processual foi alçado, no âmbito da sociedade e do Direito Administrativo, a um dos institutos mais importantes, sobretudo do ponto de vista da democracia, sistema intimamente vinculado ao comando do Estado de Direito.

Pode-se afirmar, como marco inaugural do ramo referente ao Direito Administrativo, a queda do Ancién Régime, uma vez que, antes da Revolução Francesa, do século XVIII, o Estado era considerado patrimônio do Soberano, não havia Estado de Direito, 
o poder advinha do Governante e este ditava o que lhe convinha sob os aspectos principais das funções estatais, isto é, governar, legislar e julgar.

Após a Revolução Francesa, referida noção de acumulação de poderes em uma só pessoa - a que Mario G. Losano se refere como "pacto subiectiones". 1 - cedeu lugar à noção de "pacto unionis", posicionando "[...] o príncipe vinculado à lei, em particular, àquela lei fundamental que é a constituição; que o Estado não é mais seu, mas da classe que detém o poder". 2

Nesse momento de transformação política na Europa do século XVIII, incorporase, ainda, a noção de tripartição funcional do poder, visando, sobretudo, estabelecer um governo de leis, em que a limitação do poder seria preestabelecida pela sociedade e também levada ao seu conhecimento. Verifica-se o rompimento da fórmula absolutista de Estado para a novel concepção democrática, principalmente na Europa, o que contribuiu para a formação e o desenvolvimento do Direito Administrativo e, consequentemente, abriu margem para o desabrochar do processo em seu seio.

Com efeito, na Europa pós-revolução ${ }^{3}$, estabeleceram-se as bases doutrinárias do Direito Administrativo que, hoje, vigoram nos principais Estados europeus e Estados SulAmericanos colonizados. É o que anota Edmir Netto de Araújo:

[...] Todavia, quando se diz que o aparecimento do Direito Administrativo como disciplina autônoma coincidiu com o Estado de Direito, se localiza uma das razões de sua autonomia tardia. É que a grande conquista da Revolução Francesa de 1789 foi submeter também o Estado ao império da lei $[\ldots]^{4}$

No tocante à doutrina edificada no século XIX sobre o Direito Administrativo como ramo autônomo de Direito, Edmir Netto de Araújo ressalta que, inicialmente, foi Charles Jean Bonin a publicar, em 1808, na França, a obra Principes d'Administracion

\footnotetext{
${ }^{1}$ LOSANO, Mário G. Os Grandes Sistemas Jurídicos. Tradução Marcela Varejão. São Paulo: Martins Fontes, 2007. p. 92.

${ }^{2}$ LOSANO, Mário G. Os Grandes Sistemas Jurídicos. Tradução Marcela Varejão. São Paulo: Martins Fontes, 2007. p. 92.

${ }^{3}$ Losano aponta GIAN DOMENICO ROMAGNOSI, autor da obra Princípios gerais do direito administrativo, datada de 1814, como o precursor da sistematização do Direito Administrativo na condição de nova disciplina e afirma "[...] No século XIX, a gênese do direito administrativo é explicada de dois modos. De um lado, sustentase que, independente de Romagnosi, o direito administrativo sempre existira, mas não uma ciência. De outro, objetou-se que exatamente a nova situação gerada pela Revolução Francesa levara à criação de um novo setor do direito, [...] . Essa tese (sustentada na França por Hariou, na Suíça por Fleiner e na Itália por Zanobini) foi consolidada pela constatação de que o direito inglês - não tendo sofrido o corte evidente entre o mundo feudal e mundo burguês realizado pela Revolução Francesa - não conhece um direito administrativo, [...]“ (LOSANO, Mário G., Os Grandes Sistemas Jurídicos. Tradução Marcela Varejão. São Paulo: Martins Fontes, 2007. p. 94).

${ }^{4}$ ARAÚJO, Edmir Netto de. Curso de Direito Administrativo. 5. ed. São Paulo: Saraiva, 2010. p. 24.
} 
publique, diferenciando pela primeira vez o Direito Administrativo do Constitucional. E mais a criação da cátedra de Direito Administrativo da Universidade de Paris, por Luis XVIII, em 1819 (restauração da Monarquia), para cuja regência fora designado o Barão de Gérando, sucedido, após sua morte, pelo Conselheiro de Estado Macarel, a partir de 1852, fora o evento que impulsionou a criação de diversas obras sobre Direito Administrativo por diversos autores do período oitocentista, dentre eles, Foucart, Chaveau e Laferrière. ${ }^{5}$

Complementando, Edmir Netto de Araújo acentua que

[...] não é sem razão que se costuma apontar como marco inicial do Direito Administrativo uma lei francesa do ano de 1800 (naquele excêntrico calendário francês da época, de "28 pluviose do ano VIII"), que, pela primeira vez, dotou a Administração de uma organização juridicamente garantida e estável, exteriormente obrigatória a todos os administrados. ${ }^{6}$

De fato, normas sobre organização e funcionamento de uma coletividade sempre existiram em civilizações antigas. Mas o que se discute acerca da formação do Direito Administrativo e de sua evolução nos sistemas jurídicos de origem romana é que, diferentemente do que ocorreu no Direito de origem anglo-saxã, foi após a revolução francesa que referida matéria alcançou o status de disciplina autônoma, sendo que, em face da estrutura política da França e da criação do contencioso administrativo, por força das decisões do Conselho de Estado francês, foram sendo delineados os axiomas e as bases da teoria do Direito Administrativo, o que posteriormente foi levado aos Estados sob a influência do direito romano.

Alemanha e Itália, de sua parte, contribuíram no desenvolvimento do Direito Administrativo no século XIX; no entanto, devido às unificações tardias dos respectivos Estados, seus estudos surgiram em décadas posteriores aos elaborados na França. São consideradas, porém, escolas com inestimáveis contribuições à sistematização do Direito Administrativo, citando-se autores como Laband e Otto Mayer, na Alemanha, e o próprio Romagnosi na Itália.

Relata Edmir Netto de Araújo que, a partir do desenvolvimento da doutrina de Direito Administrativo na França, Itália e Alemanha, esse ramo do Direito, com a sua autonomia, se alastrou, atingindo o mundo ocidental. Pondera:

\footnotetext{
${ }^{5}$ ARAÚJO, Edmir Netto de. Curso de Direito Administrativo. 5. ed. São Paulo: Saraiva, 2010. p. 31.

${ }^{6}$ ARAÚJO, Edmir Netto de. Curso de Direito Administrativo. 5. ed. São Paulo: Saraiva, 2010. p. 31.
} 
[...] com influências localizadas de cada um deles ou de todos eles, como se vê no estudo dessa disciplina na Espanha, Bélgica, Suíça, Holanda, Áustria, Portugal, Grécia etc., e nos distantes (da Europa), países da América, como Brasil, Argentina, Uruguai, Chile, Peru, Venezuela, México etc., e mesmo no longínquo Japão, além de outros direitos. [...]. ${ }^{7}$

A emergência e o percurso do Direito Administrativo na Inglaterra, nos Estados Unidos e nos países integrantes do bloco da Common Law, como Escócia, Irlanda do Norte, Irlanda do Sul, País de Gales, e outros de colonização britânica, baseou-se em outra ideia, considerando a experiência desses Estados ser lastreada no sistema da "common law", isto é, em decisões jurisprudenciais e na equidade.

No entanto, mesmo com perfil menos positivista e diante da existência de outros fatores que reforçavam as diferenças entre o desenvolvimento do Direito Administrativo nesse ambiente em comparação aos Estados de origem romanística, não se pode negar que havia normas de natureza própria ao Direito Administrativo nos países do grupo da Common Law.

$\mathrm{Na}$ Inglaterra, pode-se dizer que a existência do Direito Administrativo não fora aceita nos moldes verificados na França, considerada precursora. A resistência aflorava da ideia da inexistência de uma jurisdição diferenciada para julgar o Estado, bem como da inviabilidade de resguardar prerrogativas e direitos preponderantes em favor da Administração em relação aos administrados. Proclamava-se a existência de um direito comum, para todos.

Di Pietro afirma que

[...] No que diz respeito ao Direito Administrativo no sistema angloamericano, o seu nascimento, além de posterior ao do sistema continental, não teve a seu favor as razões históricas que justificaram a interpretação que na França se deu ao princípio da separação dos poderes e inspiraram a criação do contencioso administrativo. Na Inglaterra e nos Estados Unidos, o Poder Judiciário exerce sobre a Administração Pública o mesmo controle que exerce sobre os particulares, graças ao apego aos princípios da rule of law, na Inglaterra, judicial supremacy e due processo of law, nos Estados Unidos. ${ }^{8}$

Complementa a autora:

[...] Enquanto aos franceses, após a revolução, repugnava a ideia de submeter a Administração ao Judiciário em consequência dos apontados antecedentes históricos, na Inglaterra e nos Estados Unidos os revolucionários dos séculos XVII e XVIII, respectivamente, receavam os excessos do Poder Executivo, razão pela qual registrou-se a tendência oposta

\footnotetext{
${ }^{7}$ ARAÚJO, Edmir Netto de. Curso de Direito Administrativo. 5. ed. São Paulo: Saraiva, 2010. p. 34.

${ }^{8}$ DI PIETRO, Maria Sylvia Zanella. Direito Administrativo. 25. ed. São Paulo: Atlas, 2012. p.12.
} 
de atribuir ao Judiciário e ao Legislativo maiores poderes de controle. Havia grande resistência ao nascimento do Direito Administrativo, que era visto como um conjunto de normas que asseguravam privilégios e prerrogativas para a Administração frente ao particular, parecendo mais como direito próprio dos regimes totalitários. [...]. ${ }^{9}$

Realizando breve esforço comparativo entre os sistemas de origem romanística e anglo-saxã, percebe-se que o ponto de divergência significante entre eles é o modo pelo qual se deu a constituição dos respectivos Estados modernos e os novos enquadramentos políticoinstitucionais que ocorreram nesses Estados.

Isso conduziu à utilização do regime jurídico de direito privado nas relações entre a Administração e os governados no regime da Common Law e ao desenvolvimento tardio do Direito Administrativo. No entanto, não se nega a existência desse específico segmento do Direito em ambos os sistemas.

Nessa esteira, Edmir Netto de Araújo lembra que tanto na Inglaterra como no panorama norte-americano, na contemporaneidade, se aceita

[...]a existência de um conjunto de regras administrativas, embora subsistindo a equivalência de posições (horizontalidade) entre a Administração e o cidadão, especialmente perante o Judiciário.

Em decorrência desta filosofia privatística, nesses países proliferam colegiados, comissões e organismos "quase" jurisdicionais [...] para examinar questões e litígios de ordem administrativa, e mesmo para filtrar o acesso do cidadão ao Judiciário, evitando o congestionamento deste.

Portanto é de horizontalidade a atuação da Administração (mesmo patamar), típica de direito privado, ao contrário da verticalidade (puissance publique) do Direito Administrativo romanístico, no qual a Administração se coloca em posição de supremacia nas relações com os administrados e mesmo com seus próprios agentes, quando age utilizando as prerrogativas de autoridade pública. [...]. ${ }^{10}$

Essa diferença entre a evolução do Direito Administrativo de origem romanística e o de origem anglo-saxã apresenta relevância, uma vez que ambos os sistemas produziram influência sobre o percurso evolutivo do Direito Administrativo brasileiro, inclusive sobre o instituto do processo.

Por evidente que, entre nós, a Europa, mormente França, Itália e Alemanha, países de origem romanística, e principalmente as decisões do Conselho de Estado francês, inspiraram as linhas basilares do instituto do processo administrativo.

\footnotetext{
${ }^{9}$ DI PIETRO, Maria Sylvia Zanella. Direito Administrativo. 25. ed. São Paulo: Atlas, 2012. p.12.

${ }^{10}$ ARAÚJO, Edmir Netto de. Curso de Direito Administrativo. 5. ed. São Paulo: Saraiva, 2010. p. 37.
} 
Contudo, aqui no Brasil, em um contexto político-institucional federativo, sobretudo após a proclamação da república com a extinção do Conselho de Estado, adotou-se a jurisdição una, típica do modelo norte-americano e inglês.

\subsubsection{O fenômeno processual - A trajetória e a relevância em sede de Direito Administrativo}

O fenômeno processual surge no contexto do Direito e da sociedade como instrumento apto a servir o Estado, com a finalidade de solucionar conflitos de interesse através da participação de um terceiro, imparcial, alheio e capaz de impor sua decisão às vontades das partes, diferente da solução de conflitos a que se refere a técnica da autocomposição e a autodefesa ou autotutela.

É que no primeiro, isto é, na autocomposição, há uma perda ou renúncia de direitos entre as partes ou de uma das partes, e, no segundo, a autodefesa ou autotutela, a parte mais forte faz prevalecer seus interesses; ambas, todavia, não contam com a participação de um terceiro imparcial e mais forte para solução do conflito. ${ }^{11}$

Quando abordamos o tema relativo à forma de solução de conflitos, identifica-se, na autodefesa ou autotutela, a mais primitiva das fórmulas existentes nas civilizações anteriores ao século II aC.

Isso em razão de não demandar outros fatores senão um conflito que se resolvesse pela parte mais forte impondo à mais fraca o direito guerreado entre elas.

Não existia nessa época um Estado apto e forte para impor sua vontade, através de normas preexistentes, e uma atuação soberana do Estado com relação à Sociedade, o que condizia com uma fração inexistente de justiça oriunda do modelo da "vingança privada". ${ }^{12}$

Ainda nas civilizações mais antigas, antes do século II $\mathrm{aC}$, o modelo de autocomposição era praticado como forma de solução de conflitos, considerando que, em um

\footnotetext{
11،A eliminação dos conflitos ocorrentes na vida em sociedade pode-se verificar por obra de um ou de ambos os sujeitos dos interesses conflitantes, ou por ato de terceiro. Na primeira hipótese, um dos sujeitos (ou cada um deles) consente no sacrifício total ou parcial do próprio interesse (autocomposição) ou impõe o sacrifício do interesse alheio (autodefesa ou autotutela). Na segunda hipótese, enquadram-se a defesa de terceiro, a conciliação, a mediação e o processo (estatal ou arbitral)". (CINTRA, Antônio Carlos de Araújo; GRINOVER, Ada Pellegrini; DINAMARCO, Cândido R. Teoria Geral do Processo. 27. ed. São Paulo: Malheiros, 2011. p.26).

12 Nesse sentido, o entendimento de: CINTRA, Antônio Carlos de Araújo; GRINOVER, Ada Pellegrini; DINAMARCO, Cândido R. Teoria Geral do Processo. 27. ed. São Paulo: Malheiros, 2011. p.27.
} 
primeiro momento, era realizada sem a interferência de um árbitro ou um terceiro, e em um modelo mais avançado, passou-se a se demandar a participação de um terceiro, um árbitro, que, no entanto, limitava-se a declarar o Direito, ainda pendente de força executória. Era insuficiente, uma vez que se arbitrava a justiça com parcialidade e sem uma norma prévia.

À medida que o Estado foi se fortalecendo, a solução de conflitos passou a contar com maior participação do Estado; ainda não com a força necessária para impor sua vontade ao caso concreto, mas, ao menos, afastando-se do sistema da autotutela, de caráter primitivo e inconcebível no seio de sociedades organizadas.

Entre os séculos II aC e II dC, chamado período arcaico e clássico do direito romano, com o desenvolvimento do Estado Romano, este foi se afirmando e impondo gradativamente sua vontade na esfera da liberdade dos indivíduos, datando de tal época a Lei das XII Tábuas - ano $450 \mathrm{aC}$, marco fundamental. Apenas a partir do século III dC, o Estado Romano passou a, efetivamente, decidir em conflitos de interesse entre os indivíduos, completando o ciclo histórico da evolução da chamada justiça privada para a justiça pública.

Nas palavras de Cintra, Grinover e Dinamarco

[...] O Estado, já suficientemente fortalecido, impõe-se sobre os particulares e, prescindindo da voluntária submissão destes, impõe-lhes autoritativamente a sua solução para conflitos de interesses. À atividade mediante a qual juízes estatais examinam as pretensões e resolvem os conflitos dá-se o nome de jurisdição. ${ }^{13}$

E o processo, nesse sentido, passa a representar o instrumento pelo qual o Estado irá solucionar o conflito de interesse entre os indivíduos e fazer prevalecer o comando normativo que deveria ser aplicado a cada caso.

No entanto, quando se fala em jurisdição, o processo torna-se fenômeno absolutamente irrefutável, isto é, "instrumento por meio do qual os órgãos jurisdicionais atuam para pacificar as pessoas conflitantes, eliminando os conflitos e fazendo cumprir o preceito jurídico pertinente a cada caso que lhes é apresentado em busca de solução". ${ }^{14}$

De se assinalar, pois, que, até a primeira metade do século $\mathrm{XX}$, havia a predominância de uma concepção privatista do processo, na qual a jurisdição tinha por objetivo principal direitos subjetivos e a afirmação da doutrina do direito processual era

\footnotetext{
13 CINTRA, Antônio Carlos de Araújo; GRINOVER, Ada Pellegrini; DINAMARCO, Cândido R. Teoria Geral do Processo. 27. ed. São Paulo: Malheiros, 2011. p.29.

14 CINTRA, Antônio Carlos de Araújo; GRINOVER, Ada Pellegrini; DINAMARCO, Cândido R. Teoria Geral do Processo. 27. ed. São Paulo: Malheiros, 2011. p. 29.
} 
marcada pela construção de grandes teorias, dificultando, pois, a idealização da teoria processual nos outros ramos do Direito, um processo atinente a outros Poderes. ${ }^{15}$

Para os administrativistas, como Gordillo ${ }^{16}$, o processo também era visto na perspectiva de monopólio jurisdicional, uma vez que a ideia de processo no seio da Administração conflitava com seu modo de atuação liberal. O foco central da análise era o ato administrativo, e não as fases que o antecediam, somando-se à dificuldade dos administrativistas em se condicionarem para uma teoria de processo desvinculada da jurisdição, aproximando-os mais do conceito de procedimento para denominar alguns esquemas processuais já existentes na Administração.

A partir do fim do século XIX e durante a primeira metade do século XX, começa a despontar a ideia de uma processualidade ligada às três funções do Estado, o que permeou as doutrinas e estudos das décadas subsequentes até culminar, a partir da segunda metade do século $\mathrm{XX}$, em uma convergência de processualistas ${ }^{17}$ e $\operatorname{administrativistas}{ }^{18}$, afirmando a existência de um esquema processual relativo à atuação dos Poderes Estatais. É o momento da emergência de uma teoria geral do processo.

Importante, nesse contexto de ampla processualidade, recordar Adolf Merk1, autor austríaco, integrante da Escola de Viena, que ensina ser o processo uma manifestação dinâmica, uma sequência de atos interligados por um propósito jurídico anterior, o ser e o vir a ser. É, ainda, frequentemente citado como o precursor dos estudos sobre a existência de um núcleo comum de processualidade e afirma

[...] o processo é o meio pelo qual a manifestação jurídica de um plano superior produz manifestação jurídica de um plano inferior. Assim, no plano global de uma teoria dos atos jurídicos, o processo jurídico de desenvolvimento progressivo das manifestações de vontade deve se aplicar a todos os atos estatais, nenhum tendo o monopólio do processo. ${ }^{19}$

15 MEDAUAR, Odete. A Processualidade no Direito Administrativo. 2. ed. São Paulo: Ed. Revista dos Tribunais, 2008. p. 15.

16 MEDAUAR, Odete. A Processualidade no Direito Administrativo. 2. ed. São Paulo: Ed. Revista dos Tribunais, 2008. p. 15.

17 Odete Medauar cita, na doutrina de Direito Processual Estrangeira, entre alguns, Carnelutti, Couture, Hans Schima e Fazzalari, bem como, na Doutrina Processual Pátria, Ada Pelegrini Grinover, Araújo Cintra e Cândido Dinamarco (MEDAUAR, Odete. A Processualidade no Direito Administrativo. 2. ed. São Paulo: Ed. Revista dos Tribunais, 2008. p. 22-25).

18 Odete Medauar cita, na doutrina de Direito Administrativo Estrangeira, entre alguns, Romero, Feliciano Benvenutti, Alberto Xavier, Hector Jorge Escola, Mario Nigro, Guy Isaac, Giorgio Berti, bem como, na Doutrina Administrativo Pátria, Bandão Cavalcanti, Cretella Junior Sobrinho, Pondé e, em doutrina menos antiga, Sundfeld (MEDAUAR, Odete. A Processualidade no Direito Administrativo. 2. ed. São Paulo: Ed. Revista dos Tribunais, 2008. p. 25-26.

19 MERKL, Adolf. Teoria General del Derecho Administrativo. México: Nacional, 1975. p. 281. 
Identificando elementos do núcleo comum de processualidade ampla, Odete Medauar assim os elenca:

[...] a processualidade ampla exprime o "vir a ser" de um fenômeno; há um período de dinâmica, em que atuações evoluem; [...] os vários pontos no tempo significam atos e atuações que se sucedem um ao outro, num encadeamento em que o momento precedente impulsiona o subsequente, até a meta final [...]; o o encadeamento sucessivo dos atos ocorre não como algo eventual ou meramente lícito, mas como algo juridicamente necessário e obrigatório; a figura jurídica do processo é distinta da figura do ato, mas ambas guardam correlação, como instrumentalidade da primeira em relação ao segundo; [...] Embora dotados de vida própria, os atos da série final encontram sua razão de ser na decisão final [...]; $\mathrm{O}$ ato resultante da cooperação de várias pessoas é imputado ao ente estatal que o emite; os sujeitos que exercem atividades no esquema processual estão interligados por direitos, deveres, ônus, poderes, faculdades. Essa complexa ligação entre os sujeitos compõe-se, então, de posições jurídicas ativas e passivas de cada um deles. $[\ldots]^{20}$

A partir deste núcleo comum e reflexo da doutrina das funções dos poderes e do exercício de suas respectivas atividades, surge a viabilidade de cada um dos Poderes produzir seus atos por intermédio de um processo identificado com suas respectivas características funcionais. O processo administrativo passa a se destacar no seio da função administrativa do Estado; o processo legislativo perante a função legislativa; e o processo judicial perante a função judiciária do Estado.

Retomando o raciocínio inicial no que tange à evolução do Direito Administrativo, resta evidenciado que foi nos países de tradição romanística que o instituto do processo administrativo se desenvolveu e, nesse figurino, foi albergado pelo direito brasileiro. Desde a relutância em aceitá-lo, passando pela fase do exame do ato administrativo com foco central, atinge-se um retrato de Direito Administrativo em que não mais se cogita da atividade administrativa desvinculada do processo.

No direito estrangeiro, frequente a menção à palestra proferida por Feliciano Benvenutti, em 1951, junto à Faculdade de Ciência Política da Universidade de Pádua, na qual introduziu um conceito de processo administrativo ligado à função administrativa. Para o autor, o processo administrativo corresponderia à ação e ao resultado da atividade administrativa em relação aos seus fins. Isso com observância da norma em vigor, afirmando 
que “[...] o processo é o histórico da transformação do poder em ato, de acordo com cada função estatal e sopesadas as garantias legalmente protegidas". ${ }^{21}$

Essa reorientação não significou a perda da importância do instituto do ato administrativo. Demonstra, todavia, uma nova forma de agir da Administração, menos arbitrária, menos ineficiente, e, sobretudo, mais democrática, considerando o contexto político institucional do Estado de Direito no direito pátrio em vigor.

\subsubsection{O processo administrativo na sua evolução em cenário brasileiro}

Entre nós, o processo administrativo no Império, entre 1822 e 1889, não detinha a mesma relevância que hoje lhe é atribuída. Naquele período, praticava-se o contencioso administrativo $^{22}$, que marca a primeira fase do Direito Administrativo no Brasil. Notória a arbitrariedade, própria à época imperial.

A partir de 1891, com a Constituição republicana, prescreveu-se o acesso ao Poder Judiciário para enfrentar a Fazenda Pública, diga-se o Estado. O documento constitucional marca a abolição do contencioso administrativo, com viés francês, no Brasil, prevalecendo até o momento o sistema de unicidade. ${ }^{23}$

Destarte, desde a proclamação da República - e a consequente extinção do Conselho de Estado no Brasil -, o processo administrativo deixa de ser caracterizado como jurisdicional; no entanto permanece como instrumento para a realização da justiça administrativa e caminho para a atuação da Administração, ainda que, por longo período,

21 BENVENUTTI, Feliciano. Função Administrativa, Procedimento e Processo. In: Rivista Trimestrale di Diritto Pubblico, 1952. p. 118-145.

22 No Brasil colonial e imperial pós-independência, havia um contencioso administrativo o qual pode-se dizer que seguiu um formato inicial semelhante ao contencioso administrativo francês: "No Brasil Colônia, é frequente o uso do contencioso administrativo. Proclamada a Independência, a Constituição de 1824, ao lado dos três Poderes clássicos, previa um quarto Poder (Moderador), conferindo ao Imperador, com atribuições que lhe possibilitavam a manipulação dos Poderes Judiciário e Legislativo (art. 10). O artigo 137 da Constituição do Império mantinha a existência do Conselho do Estado [...] com funções consultivas e judicantes [...]" (GRINOVER, Ada Pellegrini. As garantias constitucionais do direito de ação. São Paulo: RT, 1973. p. 149).

23 A expressão "contencioso administrativo" retornou ao texto constitucional com a Emenda de 1969, no entanto a própria Comissão de Estudo do Contencioso Administrativo, nomeada pelo então ministro da Justiça, Professor Buzaid, sendo composta por Wilson de Campos Batalha, Camilo Ashchar e Cretella Júnior, através de conclusões referentes ao estudo da implementação do instituto em referência, afirmara pela inviabilidade jurídica do sistema "repristinado". Vide: GRINOVER, Ada Pellegrini. As garantias constitucionais do direito de ação. São Paulo: RT, 1973. p. 151-153. 
eivada de vícios da época Imperial, mormente no que tange à ampla defesa e contraditório acesso ao processo e à publicidade de suas decisões.

A esse passo, importante registrar a abordagem do instituto do processo administrativo na doutrina pátria clássica e na atual, em especial no que concerne à diferença entre processo e procedimento. Isso apesar do ensinamento de Edmir Netto de Araújo ${ }^{24}$, no sentido de que referido tema possui notoriedade mais teórica do que prática, visto que diz respeito apenas ao nome que se deseja dar ao instituto, não alterando sua prática e nem a norma que sobre o indigitado instituto se aplica. Em sede administrativa, no entanto, a discussão sobre o termo mais apropriado continua se revelando rica e instigante.

No que tange ao Direito alienígena, em que se adotou o sistema dúplice de jurisdição, como Itália, o termo processo administrativo designa os processos que tramitam pela justiça administrativa, reservando-se o termo procedimento para aqueles que se desenvolvem no âmbito da Administração. Na França, o termo referente ao procedimento italiano foi denominado de processo administrativo não contencioso.

Benvenuti $^{25}$ afirma que processo administrativo configura espécie de procedimento, sendo este termo mais genérico e aquele mais adequado para designar aqueles procedimentos administrativos nos quais há participação das partes em contraditório. Assim, para Benvenuti, procedimento administrativo traduz a transformação do poder em ato, no âmbito do Administrativo, através da função administrativa; uma vez qualificado pela participação de interessados em contraditório, o termo referendado deveria ser processo administrativo.

Abordando a questão, Sergio Ferraz e Adilson de Abreu Dallari ${ }^{26}$ oferecem três critérios para o tratamento da diferença entre os termos processo e procedimento no âmbito do Direito Administrativo pátrio: o lógico, o normativo e o ideológico. Optam, claramente, pelo termo processo administrativo, principalmente em vista de esse termo ter como arquétipo o processo civil, com o qual interessa manter-se vínculo, até porque a própria Constituição Federal de 1988 e a Lei de Processo Administrativo Federal, datada de 1999, adotam o termo processo administrativo. Ademais, lembram os autores que o termo processo administrativo invoca uma característica mais substancial, a que sempre se aspirou assegurar ao processo.

\footnotetext{
24 ARAÚJO, Edmir Netto de. Curso de Direito Administrativo. 5. ed. São Paulo: Saraiva, 2010. p. 916-917.

25 BENVENUTTI, Feliciano. Função Administrativa, Procedimento e Processo. In: Rivista Trimestrale di Diritto Pubblico, 1952. p. 118-145.

26 FERRAZ, Sérgio; DALLARI, Adilson Abreu. Processo Administrativo. São Paulo: Malheiros, 2001. p. 34-35.
} 
Como direito público subjetivo, uma garantia mais robusta em comparação a uma noção de direito instrumental e adjetivo, mais consentânea com o procedimento.

Edmir Netto de Araújo ${ }^{27}$ adota o termo processo administrativo, inspirando-se na doutrina italiana, e registra:

A doutrina processualista italiana oferece-nos a ideia de provimento, como todo ato estatal de autoridade, como a lei, o regulamento, o ato administrativo e a sentença, para o qual concorre uma série de atos preparatórios que constituem o procedimento. Aliás, no Direito Administrativo italiano, "provvedimento" significa, frequentemente, "atto amministrativo" especialmente se envolve decisão do agente. O provimento praticado pelo Estado, nesse raciocínio, pode resultar de um procedimento simples, apenas formalizando passos em direção ao objetivo visado; ou então, estruturado em forma contraditória, para permitir decisão sobre interesses antagônicos e resistidos, caso em que teremos o processo. Esta é a nossa posição [...].

De certo, nos parece mais apropriada a utilização do termo processo administrativo, isto é, no sentido do conjunto dos atos preparatórios, cujos participantes operam em sistema de contraditório, que irão servir para um ato final a ser exarado pela Administração, sendo o procedimento a técnica e a singularidade desses atos que antecedem o ato final, ou seja, processo é o conjunto e procedimento seria cada uma das diversas partes desse conjunto.

Ademais, é de se assinalar que a expressão "processo administrativo" foi a opção utilizada em nossa atual Constituição Federal de 1988, bem como nas Leis que disciplinam o Processo Administrativo na esfera federal e na estadual.

\subsection{O ESTADO DE DIREITO E SEUS COMANDOS}

Oportuno assinalar, como pontuado por Edmir Netto de Araújo, que

[...] a evolução da espécie humana congregada em coletividades, gradativamente, obrigou a que se substituísse o costume de se fazer justiça pelas próprias mãos por outro sistema mais racional e adequado ao incremento cultural que se verificou com o nascimento da ordem jurídica, resultado direto da criação, pelo homem, da entidade abstrata, denominada Estado, destinada a governar essas coletividades. ${ }^{28}$

\footnotetext{
27 ARAÚJO, Edmir Netto de. Curso de Direito Administrativo. 5. ed. São Paulo: Saraiva, 2010. p. 917.
}

28 ARAÚJO, Edmir Netto de. Curso de Direito Administrativo. 5. ed. São Paulo: Saraiva, 2010. p. 1276. 
Nesta perspectiva, a clássica lição de Georges Burdeau ${ }^{29}$, de que "não há qualquer período na história em que os homens, ao menos os mais conscientes deles, não tenham tentado afirmar sua liberdade em contraposição ao poder". Derivam, destarte, desta eterna preocupação dos indivíduos com a preservação de sua liberdade, as diferentes fórmulas de limitação do Poder político, porquanto já célebre a observação do Barão de la Brède e de Montesquieu no sentido de que "todo homem que tem poder é tentado a abusar dele; vai até onde encontra limites". 30

Nesta esteira e com a perspicácia que lhe é peculiar, aponta Manoel Gonçalves Ferreira Filho o extenso elenco de sistemas desenvolvidos ao longo dos séculos, exatamente com o escopo de introduzir barreiras ao poder, mecanismos de frenagem à tendência centrípeta que é da sua natureza.

No seu já clássico Curso de Direito Constitucional ${ }^{31}$, como ainda em outras obras e, de modo pontual no livro Princípios Fundamentais de Direito Constitucional ${ }^{32}$, o mestre indigita a secular ideia da Rule of Law, formulada pelos ingleses e, mais tarde, sob o impacto da obra de Montesquieu, a doutrina da separação de poderes, consagrada no art. 16, da Declaração Francesa dos Direitos do Homem e do Cidadão de 1789, e que se consolidou ao longo dos anos, sendo adotada pelas constituições em quase todas as partes.

É neste escaninho - mecanismos de limitação do poder - que se situa a receita do Estado de Direito, cuja matriz é detectada na Alemanha, sob a denominação de "Rechtsstaat", conforme ensina Chevallier ${ }^{33}$. Ressalta-se que se costuma atribuir a Johann Wilhelm Placidus, na data de 1798, a utilização pioneira da expressão "Rechtsstaat"; no entanto, há controvérsia sobre quem de fato teria cunhado o termo, uma vez que autores como Hayek atribuem o termo a Welcker, utilizado no ano de 1813, para designar um determinado tipo de governo, dentre as três espécies que identificava: o despotismo, a teocracia e (exatamente) o Rechtsstaat. ${ }^{34}$

\footnotetext{
$29 \quad$ BURDEAU, Georges. Les Libertés Publiques. Paris: Librairie Généralle de Droit et Jurisprudence, 1972. p. 24.

30 MONTESQUIEU, Charles-Louis de Secondat, Barão de la Brède et de. Do Espírito das Leis. Tradução Fernando Henrique Cardoso e Leôncio Martins Rodrigues. São Paulo: Difusão Europeia do Livro. p 179.

31 FERREIRA FILHO, Manoel Gonçalves. Curso de Direito Constitucional. 32. ed. São Paulo: Saraiva, 2006.

32 FERreira FILHO, Manoel Gonçalves. Princípios Fundamentais do Direito Constitucional. 2. ed. São Paulo: Saraiva, 2010.

33 CHEVALLIER, Jacques. L'etat de droit. Paris: Montchrestien, 1992. p. 11-23 e 31-33.

34 FERrEIRA FILHO, Manoel Gonçalves. Princípios Fundamentais do Direito Constitucional. 2. ed. São Paulo: Saraiva, 2010. p. 178 e nota de rodapé.
} 
De toda forma, superado o período das monarquias absolutistas europeias, que permearam os séculos XV a XVIII, profundamente demarcado pela concentração de poder ilimitado nas mãos de um "homem", o Monarca, destaca-se no seio das sociedades o desenvolvimento de nova noção, a de Estado de Direito, que influenciou ordenamentos jurídicos de diversos países, mormente aqueles plasmados no sistema romano-germânico, os quais, a seu turno, representam fonte de inspiração direta do nosso sistema jurídico.

Importante ressaltar, a este passo, a relevância da ideia de Estado de Direito para o campo administrativo, porquanto a evolução deste novo ramo vai se processar e desenvolver sob o impacto da célebre fórmula. Neste diapasão, o magistério de Carl Schmitt que acentua ser meritório do rótulo Estado de Direito: “[...] somente o Estado cuja Administração esteja dominada, segundo a expressão de O. Mayer, pela "reserva" e "proeminência" da lei". ${ }^{35}$

E, em recente tese defendida junto a esta Faculdade de Direito da Universidade de São Paulo, em concurso de livre-docência, Fernando Dias Menezes de Almeida ${ }^{36}$ anota: “[...] é nota essencial do Direito administrativo, desde esse mesmo início, constituir um Direito que se impõe aos governantes, à Administração em sentido amplo". Prossegue o mestre: "Ou seja, o Direito administrativo nasce no contexto do moderno Estado de Direito e a ele se vincula”.

Esse entendimento é acolhido também por Mario G. Losano, no que tange às origens do direito administrativo ${ }^{37}$ :

[...] A queda do Ancien Regime exigia uma nova técnica na gestão do Estado: antes da Revolução Francesa, o Estado era patrimônio do soberano absoluto; a vontade do soberano era lei; os cidadãos eram súditos. Após a Revolução, ao contrário, afirma-se que os cidadãos estão ligados por um pactum uniones, não por um pactum subiiectiones; que o príncipe está vinculado à lei e, em particular, àquela lei fundamental que é a constituição; $[\ldots]$.

Assim emerge a ideia de que o Poder deve encontrar limites no Direito, inaugurando-se a era do princípio da legalidade a conformar a atividade da Administração e, posteriormente o da reserva da lei.

Nessa direção, oportuno recordar, também, o magistério de Zippelius, reforçando a ideia de que o padrão Estado de Direito passa a exigir o controle da Administração quanto

\footnotetext{
35 SCHMITT, Carl. Teoria de la Constitución. México: Editora Nacional. p. 151-152.

36 ALMEIDA, Fernando Dias Menezes de. Teoria do Contrato Administrativo. Uma Abordagem HistóricoEvolutiva com Foco no Direito Brasileiro. 2011. Tese (Livre-docência em Direito) - Faculdade de Direito, Universidade de São Paulo, 2011.

37 LOSANO, Mário G. Os Grandes Sistemas Jurídicos. Tradução Marcela Varejão. São Paulo: Martins Fontes, 2007. p. 92.
} 
ao atendimento da legalidade e isso "por meio de tribunais independentes". Remarca o autor: "A fim de que o Estado de Direito seja uma realidade, não basta o direito público seja definido pelas leis, mas é necessário ainda que haja uma judicatura que determine o direito aplicável $[\ldots]^{\prime,} 38$

A seu turno, o professor Edmir Netto de Araújo $^{39}$ aponta a importância da Revolução Francesa e da noção do Estado de Direito para a consolidação do Direito Administrativo, explicitando:

[...] Todavia, quando se diz que o aparecimento do Direito Administrativo, como disciplina autônoma, coincidiu com o Estado de Direito, se localiza uma das razões de sua autonomia tardia. É que a grande conquista da Revolução Francesa de 1789 foi submeter também o Estado ao império da lei, o que, nas formas de governo absolutistas e totalitárias, não ocorria (lembrem-se de Luiz XIV, "l'Etat c'est moi" ou de Dicey, "the king can do no wrong") dificultando ou mesmo impossibilitando a existência de garantias (chamadas depois de "constitucionais") ou de um conjunto de regras estáveis que disciplinassem as relações entre o Estado e os administrados que, na verdade, nada mais eram que simples "súditos" dos poderoso dominantes.

Instigante a observação de Jacques Chevallier ${ }^{40}$ com relação à autolimitação, isto é quanto à ideia de que o Estado de Direito importa na garantia de que o direito venha a se constituir um cerceamento efetivo do Poder estatal. Recorda que a lei é produto do Estado e, nessa esteira, cita Ihering para registrar que: “[...] O Estado é a única fonte do direito e somente o estado pode editar o direito e lhe garantir força obrigatória". A ideia de autolimitação, emergente da fórmula alemã, passa a constituir a base sobre a qual se desenvolve o tratamento da relação entre Estado e Direito.

Na França, a teoria foi objeto de exame por R. Carré de Malberg, entendida a fórmula Estado de Direito como mecanismo de limitação de poder, aplicando-se, contudo, concomitantemente com a doutrina de Montesquieu e a célebre fórmula da separação dos poderes. Destarte, desenvolve-se a ideia do Estado de Direito como evolução do estado legal, o que implica em que a lei deva limitar a atividade administrativa e se consubstanciar na condição do seu funcionamento. A perspectiva do sistema de estado legal importa, na

$38 \quad$ ZIPPELIUS, Reinhold. Teoria Geral do Estado. Tradução Antônio Cabral de Moncada. 2. ed. Lisboa: Fundação Calouste Gulbenkian, 1971. p 153.

39 ARAÚJO, Edmir Netto de. Curso de Direito Administrativo. 5. ed. São Paulo: Saraiva, 2010. p. 24.

40 CHEVALLIER, Jacques. L'etat de droit. Paris: Montchrestien, 1992. p. 11-23 e 31-33. 
verdade, em uma concepção política da organização do poder e busca assegurar a supremacia do poder legislativo ${ }^{41}$.

Esta questão, aliás, não deixou de ser analisada por Manoel Gonçalves Ferreira Filho $^{42}$. Este, em relação à figura do sistema de estado legal, indigita as vicissitudes do teorema jurídico Estado de Direito e recorda que

[...] depois da Segunda Guerra Mundial, há um período de ocaso. Sim, porque o positivismo havia desvalorizado o elemento Direito como qualificador do Estado, na medida em que o identifica com a lei positiva e esta com mera vontade do legislador. É o momento em que, assinala Caré de Malberg, o Estado de Direito se esvazia num Estado legal ${ }^{43}$. É a época em que grandes juristas - Kelsen, Jellinek etc. - veem na expressão um pleonasmo.

Realmente, Kelsen ${ }^{44}$ examina sob uma perspectiva crítica a ideia de sistema de estado legal e adverte que

[...] Em primeiro lugar, deve-se observar que um Estado não submetido ao Direito é impensável. [...] Não há, nem pode haver, lugar a um processo no qual o Estado, que, na sua existência, seja anterior ao direito, crie o Direito e, depois, se submeta a ele. Não é o Estado que se subordina ao Direito por ele criado, mas é o Direito que, regulando a conduta dos indivíduos e, especialmente, a sua conduta dirigida à criação do Direito, submete a si esses indivíduos. [...] Se o Estado é reconhecido como ordem jurídica, se todo Estado é um Estado de Direito, esta expressão representa um pleonasmo.

Em particular, no tocante à expressão Estado de Direito, Kelsen ${ }^{45}$ conclui que

[...] ela é efetivamente utilizada para designar um tipo especial de Estado, a saber, aquele que satisfaz aos requisitos da democracia e da segurança jurídica. - Estado de Direito - neste sentido específico é uma ordem jurídica relativamente centralizada segundo a qual a jurisdição e administração estão vinculadas às leis - isto é, às normas gerais que são estabelecidas por um parlamento eleito pelo povo, com ou sem intervenção de um chefe de Estado que se encontra à testa do governo -, os membros do governo são responsáveis pelos seus atos, os tribunais são independentes e certas

41 CHEVALLIER, Jacques. L'etat de droit. Paris: Montchrestien, 1992. p. 11-23 e 31-33.

42 FERREIRA FILHO, Manoel Gonçalves. Princípios Fundamentais do Direito Constitucional. 2. ed. São Paulo: Saraiva, 2010. p. 179.

43 O professor Manoel Gonçalves Ferreira Filho, citando Heuschling, afirma que "[...] Tal revivescência certamente está ligada ao repúdio ao totalitarismo, que pôs em foco a ideia de um Direito superior, independente da vontade abusiva do governante. De fato, em oposição ao Rechsstaat nazista, a Lei Fundamental alemã de 1949 constitucionalizou, no art. 20.1, o 'Estado de Direito republicano, democrático e social'"' (FERREIRA FILHO, Manoel Gonçalves. Princípios Fundamentais do Direito Constitucional. 2. ed. São Paulo: Saraiva, 2010. p. 179.

KELSEN, Hans. Teoria Pura do Direito. 2. ed. brasileira. São Paulo: Martins Fontes, 1987. p. 327-328. 
liberdades dos cidadãos, particularmente a liberdade de crença e de consciência e a liberdade de expressão do pensamento, são garantidas.

Avançando no exame, o professor Manoel Gonçalves Ferreira Filho ${ }^{46}$, apontando para os valores de justiça e segurança, afirma que

[...] O primeiro é, no pensamento da época, inerente à própria ideia de lei. Somente é lei a norma justa, aquela que se funda no Direito, mas num direito que emana da razão, da natureza, da divindade, jamais da mera vontade do legislador. Ou seja, um Direito justo. O outro se manifesta na proibição do arbítrio, aliás implícita na própria ideia de justiça. [...] Desses dois valores combinados resulta o ideal: um governo que se exerça por regras fixas e conhecidas, obedecendo à justiça.

Não seria despiciendo lembrar que a nossa atual Constituição consagra a fórmula Estado de Direito já no seu artigo $1^{\circ}$. O faz, em verdade, utilizando a expressão Estado Democrático de Direito, cunhada a partir da teoria do espanhol Elias Diaz com o sentido de denominar um Estado em transição para o socialismo, como salientado por Ferreira Filho ${ }^{47}$. Transcorridos mais de 22 anos da sua promulgação, porém, o modelo desenhado pelos constituintes incorporou-se à ordem jurídica pátria como um Estado sob o comando do Direito.

O tema do Estado de Direito importa e impõe também a análise dos comandos que conformam referido instituto, isto é, a legalidade, a igualdade e a justicialidade. Nesse território, ainda é a obra de Manoel Gonçalves Ferreira Filho a oferecer magnífico magistério, notadamente o estudo a que o mestre procede no seu Princípios Fundamentais do Direito Constitucional, obra já referida neste trabalho.

De fato desponta a legalidade como pedra fundamental do Estado de Direito ${ }^{48}$. A $1 \mathrm{e}^{49}$, porém, como concebida na receita do referido instituto, é a regra produto do Parlamento, expressão da vontade geral, ideia que domina o iluminismo sob a influência direta de Jean Jacques Rousseau, conhecido paladino da democracia direta cuja teoria oferece na sua obra $O$

46 FERreIRA FILHO, Manoel Gonçalves. Principios Fundamentais do Direito Constitucional. 2. ed. São Paulo: Saraiva, 2010. p. 177.

47 FERreIRA FILHO, Manoel Gonçalves. Princípios Fundamentais do Direito Constitucional. 2. ed. São Paulo: Saraiva, 2010. p. 180.

48 Manoel Gonçalves revela o princípio da liberdade como decorrente da legalidade e afirma que "[...] O princípio da legalidade é, por um lado, o primeiro a enunciar, ainda que pela negativa, o princípio geral de liberdade. O homem é livre para fazer tudo, exceto o que a lei proíbe" Aduz que a outra face do princípio da legalidade aponta para o princípio da segurança, no sentido de que a própria lei, de conhecimento prévio e público, restringe e limita a arbitrariedade (FERREIRA FILHO, Manoel Gonçalves. Princípios Fundamentais do Direito Constitucional. 2. ed. São Paulo: Saraiva, 2010. p. 182).

49 A Constituição do Brasil de 1988 prevê a legalidade nos artigos 5º, II, e 37, caput. 
Contrato Social ${ }^{50}$. Aliás, a título ilustrativo, é de se recordar que, por ingerência do famoso genebrino, a Declaração francesa de 1789 expressamente prevê, no seu artigo 6, "A lei é a expressão da vontade geral". 51

Pontue-se que, no decorrer de sua evolução, a legalidade foi objeto de intensas mutações, notadamente pela transposição ao Poder Executivo da competência de produzir normas, um poder legiferante não previsto originariamente e em absoluto confronto com a independência quanto ao exercício das funções preconizadas por Montesquieu.

O transporte de competência legislativa para o Poder Executivo, fenômeno de constante presença no período contemporâneo ${ }^{52}$, detém diversas razões para sua expansão. Dentre essas, pode-se enunciar como principais, a permissão constitucional para o Executivo elaborar leis em determinadas matérias; a transposição da importância atribuída ao referido Poder Executivo como Governo, origem da maioria dos projetos de lei; a necessidade de urgência atinente à Administração em um Estado com característica de intervenção em diversas áreas e a consequente inaptidão do Parlamento em cumprir o seu papel com eficiência dentro do contexto narrado acima.

O cânone da legalidade, portanto, passa a sofrer verdadeiro processo de deterioração, um estado de senilidade que pode vir a contaminar o próprio princípio do Estado de Direito.

Outro dos fundamentos do Estado de Direito e, de sua parte, relevante na conformação desse modelo, é o princípio da igualdade, inicialmente fruto de uma conquista em prol da isonomia de direitos, considerando-se os diferentes tratamentos que a lei outorgava às diversas classes sociais, sobretudo no Ancien Régime, bem como em relação ao próprio Estado. O que se buscava, em um primeiro momento de reivindicação, era o fim dos privilégios, uma mudança na condição jurídica.

A Constituição brasileira, em seu artigo $5^{\circ}$, caput, consagra a igualdade perante a lei na modalidade de igualdade jurídica, a qual pode ser concentrada no brocardo clássico do tratamento igual - em hipóteses iguais - e desigual - em casos desiguais, na medida de suas desigualdades. No entanto, não se pode deixar de apontar, também neste segmento, um

\footnotetext{
50 ROUSSEAU, Jean-Jacques. O Contrato Social e outros escritos. São Paulo: Cultrix, 1975.

51 Declaração de Direitos do Homem e do Cidadão, de 26 de agosto de 1789 (DUVERGER, Maurice. Constitutions et Documents Politiques. Paris: Presses Universitaire de France, 1974. p. 10).

52 "Isto já era visível à época da Primeira Guerra Mundial, embora a realidade fosse disfarçada por meio de artifícios que visavam a preservar - na aparência - a separação de poderes. Eram regulamentos praeter legem, regulamentos de necessidade etc. Mais tarde, leis genéricas cujo conteúdo na realidade viria do regulamento etc., que serviam de instrumento para essa legiferação 'envergonhada'“ (FERREIRA FILHO, Manoel Gonçalves. Princípios Fundamentais do Direito Constitucional. 2. ed. São Paulo: Saraiva, 2010. p. 187).
} 
movimento de fragilização da igualdade ${ }^{53}$ e de enfraquecimento de seus valores, que vem apresentado na obra de Ferreira Filho.

O princípio da judicialidade ou do controle do Poder Judiciário se mostra, ao lado da legalidade e igualdade, como elementar para o Estado de Direito. Culmina o mesmo princípio em uma garantia aos governados da própria imposição da legalidade, para então se fazer a justiça entre os cidadãos e o próprio Estado submetido aos ditames da legalidade. Carl Schmitt ${ }^{54}$ assevera que "[...] O ideal pleno do estado burguês de Direito culmina numa conformação judicial geral de toda a vida do Estado".

No Brasil ${ }^{55}$, o inciso XXXV, do artigo $5^{\circ}$, da Constituição Federal, prevê o princípio nos seguintes termos "a lei não excluirá da apreciação do Poder Judiciário lesão ou ameaça a direito" e acrescenta Manoel Gonçalves ${ }^{56}$ que aludido princípio da judicialidade é fortalecido pelo devido processo legal, standard previsto em nossa Constituição Federal, no inciso LIV, do seu artigo $5^{\circ}$. Ademais, ressalta “[...] Com isso, o princípio se torna mais sólido, já que impede que uma proposital alteração de estrutura do Judiciário esvazie essa garantia".

Portanto, no âmbito do Estado de Direito, as leis e o direito direcionam e controlam a atuação do Estado. Assim, a luta pelo Estado de Direito operou sempre no sentido de confrontar e conformar o poder estabelecido através da vontade geral também limitada por um direito anterior ao próprio Estado e preexistente na sociedade, sendo que, como exigências fundamentais à consagração da conquista do Estado de Direito, imperioso citar:

a) o império da lei, lei como expressão da vontade geral; b) divisão dos poderes: legislativo, executivo e judicial; c) legalidade da administração: atuação segundo lei, com suficiente controle judicial; e d) direitos e

\footnotetext{
53 "Deve-se assinalar que atualmente o princípio de igualdade parece em regressão. É inegável a tendência ao desenvolvimento de um direito de classe, que, embora para proteger o social e economicamente fraco, lhe concede privilégios em detrimento do princípio de igualdade. Também se pode observar que a intervenção do Estado no domínio econômico se tem feito não raro ao arrepio desse princípio" (FERREIRA FILHO, Manoel Gonçalves. Curso de Direito Constitucional. 32. ed. São Paulo: Saraiva, 2006. p. 283-284.

54 SCHMITT, Carl. Teoria de la Constitución. México: Editora Nacional. p. 150 e seguintes.

55 Importante citar o fenômeno da politização do Poder Judiciário ou judicialização da Política que ocorre no Brasil, bem como pelo mundo afora, que certamente não foi previsto em um contexto original da separação dos poderes, consistente no alargamento das funções de controle pelo Poder Judiciário com relação aos Poderes Executivo e Legislativo, o que se dá por diversos motivos, dentre eles a evolução do controle de constitucionalidade das leis, a certa subjetividade de comandos normativos previstos na própria constituição e leis infraconstitucionais, a evolução de novos instrumentos de atuação de controle e fiscalização por parte de órgãos do próprio Estado, como o Ministério público e a questão das ações coletivas, a afronta aos direitos fundamentais das ações da Administração em face dos governados.
}

56 FERREIRA FILHO, Manoel Gonçalves. Curso de Direito Constitucional. 32. ed. São Paulo: Saraiva, 2006. p. 284. 
liberdades fundamentais: garantia jurídico-formal e efetiva realização material. $^{57}$

\subsection{PRINCÍPIOS E REGRAS}

O Direito administrativo, como ciência, vem informado por princípios, ou seja, na lição clássica de José Cretella Júnior" ${ }^{58}$, por normas que configuram “[...] proposição, pressuposto de um sistema, que lhe garante a validade, legitimando-o". Anota, ainda, o conceituado administrativista ${ }^{59}$ : "Toda ciência implica a existência de princípios [...]", explicitando "[...] uns universais ou onivalentes; outros regionais ou plurivalentes; outros monovalentes; outros, enfim, setoriais".

De acentuada complexidade, a questão atinente aos princípios tem merecido múltiplas abordagens pela doutrina. Avulta, de peculiar interesse, o magistério de Canotilho ${ }^{60}$ que identifica os princípios - no âmbito do gênero norma jurídica - como dotados de; “(1) objectividade e presencialidade que os dispensa de estarem consagrados expressamente [...]; (2) mediação semântica mais intensa, dada a sua idoneidade normativa irradiante".

Pois bem, o Direito administrativo, ramo integrado por normas jurídicas, impõe desde logo a distinção entre os princípios e as regras. A textura normativa da ordem jurídica passa a deter a atenção dos estudiosos, tornando relevante examinar as espécies de normas, matéria que oferece polêmica nos tempos atuais, notadamente em razão da constitucionalização do Direito Administrativo, fenômeno descrito na lição de Regina Maria Macedo Nery Ferrari ${ }^{61}$ :

a força material e axiológica de tais normas constitucionais se irradia por todo o sistema jurídico, servindo de parâmetro para o Legislativo quando da criação de normas infraconstitucionais e para o Judiciário quando realiza o controle de constitucionalidade dos atos do Poder Público, condicionando, também, a interpretação de todas as demais normas do sistema.

\footnotetext{
57 MENDES, Gilmar Ferreira; COELHO, Inocêncio Mártires; BRANCO, Paulo Gustavo Gonet. Curso de Direito Constitucional. 2. ed. São Paulo: Saraiva, 2008. p.44.

58 CRETELla JÚNIOR, José. Curso de Direito Administrativo. Rio de Janeiro: Forense, 2000. p. 6.

59 CRETELla JÚNIOR, José. Curso de Direito Administrativo. Rio de Janeiro: Forense, 2000. p. 6.

60 CANOTILHO, José Joaquim Gomes. Direito Constitucional. Coimbra: Almedina, 1989. p 119.

61 FERRARI, Regina Maria Macedo Nery. A Constitucionalização do Direito Administrativo e as Políticas Públicas. In: RIBEIRO, Lauro Luiz Gomes; BERARDI Luciana Andrea Accorsi (orgs.). Estudos de Direito Constitucional, em homenagem à Profa. Maria Garcia. 2. ed. São Paulo: IOB, 2008. p. 453.
} 
Deste mesmo sentir, Alexi ${ }^{62}$ aponta a importância em distinguir regras de princípios:

[...] Essa distinção constitui um elemento fundamental não somente da dogmática dos direitos de liberdade e de igualdade, mas também dos direitos a proteção, a organização e procedimento e a prestações em sentido estrito. Com sua ajuda, problemas como efeitos dos direitos fundamentais perante terceiros $[\ldots]$ podem ser mais bem esclarecidos.

Oportuno, daí, traçar as diferenças entre princípios e regras, sobretudo pela vasta e divergente doutrina alienígena e pátria sobre o tema, especialmente com o recorte ${ }^{63}$ dado pelos direitos fundamentais. De outra parte, essa diferenciação apresenta-se relevante em face da inquestionável valoração dos princípios não só como base para a aplicação das regras, mas também como norma de alcance vinculante, o que reflete na interpretação e na forma pela qual o Direito - aqui com destaque para o Direito administrativo - irá operar sobre os fatos jurídicos.

O renomado constitucionalista de Coimbra, J.J. Gomes Canotilho ${ }^{64}$, por sua vez, após analisar as doutrinas de Larenz, Esser, Guastini, Dworkin e Alexi, entre outros, cuidou de estabelecer alguns critérios para diferenciar as normas dos princípios, sendo que, atribuindo complexidade ao desafio, assim os postulou, sugerindo:

a-) grau de abstracção: os princípios são normas com um grau de abstracção relativamente elevado; de modo diverso, as regras possuem uma abstracção relativamente reduzida. $b$-) Grau de determinabilidade na aplicação do caso concreto: os princípios, por serem vagos e indeterminados, carecem de mediações concretizadoras (do legislador do juiz), enquanto as regras são susceptíveis de aplicação directa. c-) Carácter de fundamentalidade no sistema das fontes de direito: os princípios são normas de natureza ou com papel fundamental no ordenamento jurídico devido à sua posição hierárquica no sistema de fontes (ex.: princípios constitucionais) ou à sua importância estruturante dentro do sistema jurídico (ex.: princípio do estado de Direito); d-) Proximidade da ideia de direito: os princípios são "standards" juridicamente vinculantes radicados nas exigências de "justiça" (Dworkin) ou na "ideia de direito" (Larenz); as regras podem ser normas vinculativas com um conteúdo meramente funcional; f-) Natureza normogenética: os princípios são fundamentos de regras, isto é, são normas que estão na base

\footnotetext{
62 ALEXY, Robert. Teoria dos Direitos Fundamentais. Tradução Virgílio Afonso da Silva. São Paulo: Melhoramentos, 2008. p.85.

63 "Das mais relevantes para a prática do Direito, sobretudo em âmbito constitucional, essa distinção tem como base estrutura normativo-material dos preceitos que integram a parte dogmática das constituições, com enormes reflexos na sua interpretação e aplicação, [...]” (MENDES, Gilmar Ferreira; COELHO, Inocêncio Mártires; BRANCO, Paulo Gustavo Gonet. Curso de Direito Constitucional. 2. ed. São Paulo: Saraiva, 2008. p. 30).

64 CANOtilho, J. J. Gomes. Direito Constitucional e Teoria da Constituição. 4 ed. Coimbra: Almedina, 1989. p. 1124-1125.
} 
ou constituem a ratio de regras jurídicas, desempenhando, por isso, uma função normogenética fundamentante.

Robert Alexi aduz que há dificuldade em unificar os critérios para distinção entre regras e princípios, sobretudo pela falta de clareza e polêmica desde o início das tentativas em se doutrinar a diferença que existe entre ambos os institutos e releva o critério qualitativo como o de sua preferência, registrando que "[...] as normas podem ser distinguidas em regras e princípios e que entre ambos não existe apenas uma diferença gradual, mas uma diferença qualitativa. Essa tese é correta". 65

Em relação ao critério qualitativo, assinala Alexi ${ }^{66}$ que

Princípios são, por conseguinte, mandamentos de otimização, que são caracterizados por poderem ser satisfeitos em graus variados e pelo fato de que a medida devida de sua satisfação não depende somente das possibilidades fáticas, mas também das possibilidades jurídicas. O âmbito das possibilidades jurídicas é determinado pelos princípios e regras colidentes. [...] Já as regras são normas que são sempre ou satisfeitas ou não satisfeitas. Se uma regra vale, então, deve se fazer exatamente aquilo que ela exige; nem mais, nem menos. Regras - aduz o mestre - contêm, portanto, determinações no âmbito daquilo que é fática e juridicamente possível. Isso significa que a distinção entre regras e princípios é uma distinção qualitativa, e não uma distinção de grau. Toda norma é ou uma regra ou um princípio.

Manifestando-se sobre o tema, Manoel Gonçalves relata que a distinção tradicional entre regra e princípio deve atender a uma análise quanto à abrangência e, nessa perspectiva, “[...], os princípios seriam normas jurídicas, sim, mas generalíssimas, tanto na sua hipótese quanto no seu dispositivo. Por isso, a sua diferenciação seria uma questão de grau de generalidade". ${ }^{67}$

Ademais, encampando uma postura crítica ${ }^{68}$ com relação às doutrinas modernas que postulam uma diferenciação substancial e não formal entre regras e princípios, registra o mestre que tais posicionamentos doutrinários não chegam a uma teoria clara sobre eles mesmos o que, inclusive, dificulta ao estudioso uma efetiva diretriz sobre os critérios

65 ALEXY, Robert. Teoria dos Direitos Fundamentais. Tradução Virgílio Afonso da Silva. São Paulo: Melhoramentos, 2008. p. 90.

66 ALEXY, Robert. Teoria dos Direitos Fundamentais. Tradução Virgílio Afonso da Silva. São Paulo: Melhoramentos, 2008. p. 90.

67 FERREIRA FILHO, Manoel Gonçalves. Curso de Direito Constitucional. 32. ed. São Paulo: Saraiva, 2006. p. 392.

68 "Hoje, há quem não se contente com essa diferenciação formal e pretenda haver entre princípios e regras uma diferença substancial. Entretanto, não há acordo entre os adeptos dessa tese, podendo-se distinguir diversos entendimentos quanto a essa diferença. Realmente, o que ensina Dworkin não é subscrito por Alexy; o que ensina Eros Grau não é o que entende Humberto Ávila etc" (FERREIRA FILHO, Manoel Gonçalves. Curso de Direito Constitucional. 32. ed. São Paulo: Saraiva, 2006. p. 393). 
substantivos de diferenciação. Continuando o exame, aponta Ferreira Filho dois critérios substanciais que podem ser elencados como pontos comuns, ou seja: "Um é a "otimização" inerente ao princípio. Quer dizer, a afirmação do princípio importa numa ordem, a ordem de otimizá-lo nas hipóteses que comportam a sua aplicação. O outro, "a flexibilização". O princípio, ao contrário da regra, admite temperamentos na sua aplicação".

Os princípios - consoante se depreende das ponderações acima - consubstanciamse em fundamento das regras; importam normas qualitativamente distintas e integram valores. São, portanto, fundantes e apresentam função monogenética na perspectiva de se afigurarem centros únicos de criação do Direito. Podem conviver em clima de conflituosidade; não se apresentam excludentes, impondo ao intérprete equilíbrio e harmonização na sua aplicação.

De outra parte, as regras - que encontram o seu fundamento nos princípios - não detêm o dom da prevalência na hipótese de colisão com os cânones maiores; ao invés, as regras devem se conformar aos princípios para sua validade e eficácia. Evidencia-se, pois, a necessidade de conciliação entre os princípios e, mais ainda, a imposição de tratamento adequado quando da colisão de regras ou de regras e princípios.

Esta é a visão também de Alexy que alerta: “Comum às colisões entre princípios e aos conflitos entre regras é o fato de que duas normas, se isoladamente aplicadas, levariam a resultados inconciliáveis entre si, ou seja, a dois juízos concretos de dever-ser jurídico contraditórios. E elas se distinguem pela forma de solução do conflito". ${ }^{69}$ Deve-se buscar resolver os eventuais conflitos quando da colisão entre princípios e do choque de regras, principalmente em relação aos princípios.

O dilema oferece relevância no panorama do Direito Administrativo, que possui um rol respeitável de axiomas jurídicos, tanto constitucionais quanto especiais, isto é, setoriais, exclusivos da área. Considere-se, demais disso, que, por sua vez, referidas normas encontram-se distribuídas em diversos diplomas legais e hierarquicamente desniveladas, concentrando-se o desafio em compor e resolver, por meio das técnicas de interpretação e aplicação das normas ${ }^{70}$, as possíveis colisões entre os princípios e os conflitos entre regras, tendo como norte, no caso do Direito administrativo, o interesse público.

\footnotetext{
69 ALEXY, Robert. Teoria dos Direitos Fundamentais. Tradução Virgílio Afonso da Silva. São Paulo: Melhoramentos, 2008. p. 92.

70 Para Alexy, citando a doutrina de Dworkin com relação ao conceito de dimensão do peso, "Conflitos entre regras ocorrem na dimensão da validade, enquanto as colisões entre princípios - visto que só princípios válidos podem colidir - ocorrem, para além dessa dimensão, na dimensão do peso" (ALEXY, Robert. Teoria dos Direitos Fundamentais. Tradução Virgílio Afonso da Silva. São Paulo: Melhoramentos, 2008. p. 94).
} 


\subsection{PRINCÍPIOS NO DIREITO ADMINISTRATIVO}

\subsubsection{Princípios Informativos}

Cuida-se aqui dos mandamentos que, como o próprio nome indica, possuem a característica de nortear os demais princípios de Direito Administrativo. Esta é a opinião ${ }^{71}$ de Edmir Netto de Araújo e de Di Pietro, que atraem a atenção do analista para a denominada bipolaridade do Direito Administrativo. Este, de um lado, trata do poder da Administração e, de outro, da liberdade do indivíduo. Emergem, destarte, a supremacia do interesse público e a legalidade, na condição de standards informadores.

\subsubsection{Princípio da Supremacia do Poder Público}

O princípio da supremacia do Poder Público apresenta-se como pressuposto de todo o Direito Público, na medida em que o Estado só é supremo por representar os interesses de toda a coletividade, considerando a necessidade de se estabelecer uma ordem soberana, superior e, portanto, suprema, que possa se impor aos interesses particulares.

Referido axioma não está expressamente presente na Constituição Federal, mas vem fixado no artigo 111, da Constituição Paulista, bem como no caput do artigo $2^{\circ}$, da Lei $n^{\circ}$ 9.784/99. Em ambos os textos, o princípio vem expresso na roupagem de interesse público a que está adstrita a Administração. Di Pietro ${ }^{72}$ se refere ao princípio da supremacia do interesse público, relacionando-o com a sua indisponibilidade; isto, na medida em que a disponibilidade sobre o interesse público situa-se unicamente nas mãos do Estado, dependente de manifestação legislativa, atribuindo à atividade administrativa caráter instrumental.

Edmir Netto de Araújo ${ }^{73}$ recorda que

71 ARAÚJO, Edmir Netto de. Curso de Direito Administrativo. 5. ed. revisada e atualizada. São Paulo: Saraiva, 2010. p. 70-71; e DI PIETRO, Maria Sylvia Zanella. Direito Administrativo. 25. ed. São Paulo: Atlas, 2012. p. 64-68).

72 DI PIETRO, Maria Sylvia Zanella. Direito Administrativo. 25. ed. São Paulo: Atlas, 2012. p. 65-68.

73 ARAÚJO, Edmir Netto de. Curso de Direito Administrativo. 5. ed. revisada e atualizada. São Paulo: Saraiva, 2010. p. 71. 
O princípio da supremacia do interesse público mantém intimidade com a noção de puissance publique (potestade pública) e fundamenta sua ideia nos conceitos originários da entidade "Estado", esfera em que os membros de certa coletividade, como dizia Hobbes em sua obra, Leviatã, abdicam de parte de sua liberdade integral em favor de um comando disciplinador para a vida nessa mesma comunidade, que tomará medidas para sua defesa, segurança e progresso. Como a esse comando são deferidas essas atribuições de interesse geral, em contrapartida, em nome desse interesse, ele terá o poder de ditar regras gerais de comportamento para a vida em comunidade, que devem ser por todos obedecidas, pois tais regras, de interesse geral (interesse público), devem preponderar sobre os interesses particulares.

Destarte, é sob o manto do interesse público que o Estado edita as leis e as executa, não podendo o Poder público se afastar da finalidade pública que deve atingir, por intermédio de suas funções. Constata-se desproporcionalidade entre o interesse público em relação ao privado e em se afigurando aquele supremo, resta consagrada a operacionalidade da atuação estatal voltada ao cumprimento dos interesses gerais.

Merece registro, contudo, a ideia do interesse coletivo que vem se fortalecendo já a partir do final do século XIX, sendo este o ensinamento de Di Pietro ${ }^{74}$ que observa, em relação ao Estado, uma remodelação de sua figura que "[...] deixou de ser apenas instrumento de garantia dos direitos do indivíduo e passou a ser visto como meio para consecução da justiça social, do bem comum e do bem estar coletivo". Isso implica diretamente na forma do relacionamento entre Estado e sociedade, isto é, diante do alargamento das funções do Estado, a sua postura, antes passiva, passa a encampar deveres em relação à comunidade social. É um Estado atuante e proativo.

Aduz Celso Antônio Bandeira de Mello ${ }^{75}$ que, diante da supremacia do interesse público, a Administração tem o dever de agir mediante um fim público, não havendo outra opção à Administração, sendo que "[...] as prerrogativas que nesta via exprimem tal supremacia não são manejáveis ao sabor da Administração, porquanto esta jamais dispõe de "poderes”, sic et simpliciter. Na verdade, o que nela se encontram são deveres-poderes, [...]”.

E, prossegue registrando: ${ }^{76}$ "Ora, a Administração Pública está, por lei, adstrita ao cumprimento de certas finalidades, sendo-lhe obrigatório objetivá-las para colimar interesse

\footnotetext{
74 DI PIETRO, Maria Sylvia Zanella. Direito Administrativo. 25. ed. São Paulo:Atlas, 2012. p.66.

75 BANDEIRA DE MELlo, Celso Antônio. Curso de Direito Administrativo. 29. ed. São Paulo: Malheiros, 2012. p. 100.

76 BANDEIRA DE MELlo, Celso Antônio. Curso de Direito Administrativo. 29. ed. São Paulo: Malheiros, 2012. p. 101.
} 
de outrem: o da coletividade. É em nome do interesse público - o do corpo social - que tem de agir, fazendo-o na conformidade da intentio legis".

O princípio da supremacia do interesse público, portanto, atua como pressuposto do Direito Público e conforma axioma norteador de todo o sistema de princípios do Direito Público e do Administrativo.

Consiste no dever atinente ao Estado em agir orientado por um interesse coletivo, pré-determinado pela lei, do qual não pode se afastar sob pena de invalidação do eventual ato executado.

Deste cânone decorrem os demais princípios e poderes/competências examinados no campo do Direito Administrativo, e, em particular, competências a exemplo do poder de desapropriar, de requisitar, de intervir, de policiar, de punir.

Desse standard, outrossim, resulta o tratamento especial quanto a prazos judiciais, intimações, prescrição reduzida para ações contra a Fazenda, entre outros.

\subsubsection{Princípio da Legalidade}

O princípio da Legalidade impõe ao Estado obediência à lei, e a supremacia que resulta do interesse geral deve estar vinculada ao ordenamento jurídico que instituiu o Estado, expressão da vontade geral, que em sua manifestação maior, é a Lei.

Edmir Netto de Araújo ${ }^{77}$ observa que "Estando o Estado adstrito ao interesse público, daí segue que o princípio imediatamente ligado à sua supremacia seja o da obediência, por seus agentes, da expressão da vontade geral que, sem sentido amplo, é a lei trata-se do princípio da legalidade”.

A seu turno, Hely Lopes Meirelles ${ }^{78}$ evidencia: "Na Administração Pública não há liberdade nem vontade pessoal. Enquanto na administração particular é lícito fazer tudo que a lei não proíbe, na Administração Pública só é permitido fazer o que a lei autoriza. A lei para o particular significa 'pode fazer assim'; para o administrador público significa 'deve fazer assim"”. Complementando, remarca Edmir Netto de Araújo ${ }^{79}$, citando Lucia Valle Figueiredo

77 ARAÚJO, Edmir Netto de. Curso de Direito Administrativo. 5. ed. revisada e atualizada. São Paulo: Saraiva, 2010. p. 72

78 MEIRELLES, Hely Lopes. Direito Administrativo Brasileiro. 33. ed. São Paulo: RT, 2007. p. 87-88.

79 ARAÚJO, Edmir Netto de. Curso de Direito Administrativo. 5. ed. revisada e atualizada. São Paulo: Saraiva, 2010. p. 73. 
e José Cretella Junior, que no âmbito do Direito Administrativo o princípio da legalidade é contemplado como da legalidade estrita ou princípio da restritividade.

Entre nós, a legalidade vem esculpida no inciso II, do artigo $5^{\circ}$, e no caput do artigo 37, ambos dispositivos da Constituição Federal de 1988. E mais, revelando a notoriedade do cânone, este vem apontado, ainda, no caput e no inciso II, do artigo $2^{\circ}$, da Lei $\mathrm{n}^{\mathrm{o}}$ 9.784/99, entre outros dispositivos normativos.

Di Pietro ${ }^{80}$ ressalta o alargamento do princípio da legalidade, explicitando que isso ocorreu "pela adoção dos princípios do Estado Democrático de Direito, trazendo como consequência a maior limitação à discricionariedade administrativa (em decorrência da submissão da Administração Pública a princípios e valores) e ampliação do controle judicial”.

Aliás, em relação à ampliação da legalidade, cabe o registro de que a concepção inicial do axioma, formatado nos séculos XVIII e XIX, encampava a ideia de maior relevância do Poder Legislativo, responsável pela feitura da lei, um órgão constituído por representantes do povo. Nesse período, o polo do Executivo albergava a figura do Monarca. Esta posição sofreu profunda evolução, sobretudo no que tange ao monopólio da produção da decisão política por intermédio da lei, tarefa privativa do Parlamento, sendo possível detectar - como evidenciam juristas e doutrinadores de escol - uma função normativa para o Poder Executivo.

Releva assinalar, a esse passo, a lição de Charles Eisenmann ${ }^{81}$ que, ao cuidar do conceito da legalidade, anota que "[...] para a maioria dos administrativistas e publicistas franceses o princípio da legalidade é explicado em poucas palavras".

Para o autor, o princípio da legalidade merece maior cuidado em seu trato, haja vista que, em sua opinião, as concepções do princípio da legalidade existentes estão longe de se ajustarem à realidade, mantendo complexo debate.

Expressiva é a teoria que Eisenmann ${ }^{82}$ oferece, no sentido da existência de dois termos de referência, a norma, definindo o que é necessário para o ato administrativo estar dentro dos parâmetros da legalidade, sendo o outro termo, o ato administrativo.

\footnotetext{
80 DI PIETRO, Maria Sylvia Zanella. Direito Administrativo. 25. ed. São Paulo: Atlas, 2012. p.29.

81 EISENMANN, Charles. O Direito Administrativo e o Princípio da Legalidade. Revista de Direito Administrativo, abril - junho de 1959, vol. 56, p. 49-69 (Traduzido da revista "Études et Documents", Conseil d'Etat, fasc. 11, p. 25 e ss., por Ruth Barbosa Goulart, advogada no Rio de Janeiro).

82 EISENMANN, Charles. O Direito Administrativo e o Princípio da Legalidade. Revista de Direito Administrativo, abril - junho de 1959, vol. 56, p. 49-69 (Traduzido da revista "Études et Documents", Conseil d'Etat, fasc. 11, p. 25 e ss., por Ruth Barbosa Goulart, advogada no Rio de Janeiro).
} 
Portanto, para Eisenmann, o princípio da legalidade determina a relação entre os atos ou ações administrativas e a massa imensa de normas gerais e normas individuais. Resulta, daí, a par de uma concepção mais abrangente do princípio da legalidade, outra mais restritiva. Opta o jurista, sem hesitação, pela concepção mais restritiva, invocando sua característica histórica, isto é, ela fora a concepção originária, a dos juristas ou dos publicistas liberais do século XIX, que lutaram pelo princípio da legalidade e pelo modelo de Estado de Direito, como os franceses e os países germânicos.

No entanto, esse conceito tradicional e restritivo de legalidade defendido na origem foi sutilmente ganhando novo recorte a partir do século $\mathrm{XX}$, como acima ressaltado, sendo que, hodiernamente, para boa fração da doutrina, tanto a francesa ${ }^{83}$, quanto a dominante no campo do direito comparado em geral $^{84}$ e em território doméstico, a concepção da legalidade conduz a um bloco de legalidade constituído pelas leis constitucionais, leis ordinárias, regulamentos, tratados internacionais, usos e costumes, normas jurisprudenciais, isto é, são os valores normativos que vinculam a Administração, ou seja, determinando sua submissão ao Direito ${ }^{85}$.

Com relação ao significado operacional da legalidade, Odete Medauar alerta: “[...] traduz-se, de modo simples, na seguinte fórmula: 'A Administração deve sujeitar-se às normas legais" ". ${ }^{86}$ No entanto, lembra a administrativista que esta simplicidade, na prática, é encoberta pela complexidade que é reveladora, ainda, da importância do instituto, e recorre novamente a Eisenmann ${ }^{87}$ para oferecer os significados clássicos da relação entre legalidade e atuação administrativa. Registra mais:

83 Para André de Laubadère (ideia à qual se harmoniza a maioria da doutrina administrativa), a concepção da legalidade é o conjunto das leis constitucionais, das leis ordinárias, dos regulamentos, dos tratados internacionais, dos usos e costumes, das normas jurisprudenciais, sendo os mesmos elementos de caráter escrito e não escrito, ou melhor, "um conjunto de regras de direito" sendo que Georges Vedel acrescenta, ainda, à legalidade, os atos administrativos individuais e os contratos, como espécie normativa que vinculam a Administração. In: EISENMANN, Charles. O Direito Administrativo e o Princípio da Legalidade. Revista de Direito Administrativo, abril - junho de 1959, vol. 56, p. 49-69 (Traduzido da revista "Études et Documents", Conseil d'Etat, fasc. 11, p. 25 e ss., por Ruth Barbosa Goulart, advogada no Rio de Janeiro).

Coloca o Autor em primeiro momento o fato de não aceitar literalmente a mera função executiva para os órgãos da Administração. In: ZANOBINI, Guido. L'ATTIVITÀ AMMINISTRATIVA E LA LEGGE. Artigo publicado na Revista de Direito Público, Milão, Itália, Ed. Dott A. Giuffrè, 1955. p. 204 - 208.

85 Conclui Odete Medauar: "O sentido do princípio da legalidade não se exaure com o significado de habilitação legal. Este deve ser combinado com o primeiro significado, com o sentido de ser vedado à Administração editar atos ou tomar medidas contrárias às normas do ordenamento. A administração, no desempenho de suas atividades, tem o dever de respeitar todas as normas do ordenamento" (MEDAUAR, Odete. Direito Administrativo Moderno. 15. ed. São Paulo: Revista dos Tribunais, 2011. p. 132). 
Tornaram-se clássicos os quatro significados arrolados pelo francês Eisenmann: a) A Administração pode realizar todos os atos e medidas que não sejam contrários à lei; b) A Administração só pode editar atos ou medidas que uma norma autoriza; c) somente são permitidos atos cujo conteúdo seja conforme a um esquema abstrato fixado por uma norma legislativa; d) a Administração só pode realizar atos ou medidas que a lei ordena fazer.

Conclui-se que a natureza da relação entre a norma jurídica e a atuação administrativa, dentro das variáveis de Eisenmann, deve atender a certos níveis de repercussão no elenco de garantias e de direitos do cidadão, isto é, como assevera Medauar ${ }^{88}$, "Em geral, nas medidas de repercussão mais fortes nos direitos dos cidadãos, há vinculação mais estrita da medida administrativa ao conteúdo da norma".

Para Santamaría Pastor ${ }^{89}$, hodiernamente, a relação que se estabelece entre Administração e Legalidade, conduz a “[...] A submissão plena da Administração ao Direito”. Instigante nesta esteira o entendimento de Diogo de Figueiredo Moreira Neto ${ }^{90}$, segundo o qual

[...] a juridicidade, também conhecida como legalidade em sentido amplo, e assim entendida como submissão do agir ao direito, compreende tanto a legalidade em sentido estrito, quanto a legitimidade $e$ a licitude (moralidade), constituindo-se na tríade referência da ordem jurídica para a administração pública. [...] Destarte, na atividade de administração, a violação à norma legal tipifica a ilegalidade estrita, o mau uso da discricionariedade caracteriza a ilegitimidade e a imoralidade administrativa configura a ilicitude.

Assim, pois, o vasto elenco constitucional de princípios e regras impõe à Administração Pública um comportamento mais atencioso e obediente, de molde que sua conduta venha a se pautar em consonância e com plena simetria a todos os parâmetros de legalidade, sob pena de interferência legítima do próprio Poder Judiciário, uma vez constatada uma conduta ilegal em sentido amplo.

\footnotetext{
88 MEDAUAR, Odete. Direito Administrativo Moderno. 15. ed. São Paulo: Revista dos Tribunais, 2011. p. 131.

89 PASTOR, Juan Alfonso Santamaría. Princípios de Derecho Administrativo. 3. ed. Madri: Coleccion Ceura, Editorial Centro de Estudios Ramón Areces, S/A. p. 91 (vol. I).

90 NETO, Diogo de Figueiredo Moreira. Curso de Direito Administrativo. Rio de Janeiro: Forense, 2005. Capítulo VIII, primeira página.
} 


\subsubsection{Princípios Gerais}

\subsubsection{Princípio da indisponibilidade do interesse público}

O princípio da indisponibilidade do interesse público estabelece uma vedação à autoridade pública para agir sem estar respaldada na finalidade pública ou no interesse público, standards estes previstos em lei, em sentido amplo. Edmir Netto de Araújo ${ }^{91}$ avalia que a "consequência imediata da indisponibilidade é que os direitos concernentes a interesses públicos são em princípios inalienáveis, impenhoráveis, intransferíveis a particulares, ou, em uma palavra: indisponíveis".

Por vezes denominado de princípio da finalidade pública ${ }^{92}$ e examinado em conjunto com o princípio da supremacia do interesse público ${ }^{93}$, referido axioma decorre exatamente da supremacia do interesse público ${ }^{94}$ e, como o Estado é o ente que agrega a titularidade do interesse público, só a ele cabe a guarda, a disponibilidade e o dever de agir em prol do interesse coletivo, uma vez previsto e autorizado pelo ordenamento jurídico, sendo que os órgãos e seus agentes não dispõem dessa disponibilidade, por vontade interna, deslaçada da norma.

Embora não previsto na Constituição Federal de 1988, o princípio da indisponibilidade vem inserido no artigo 111, da Constituição Paulista, bem como no caput e $\S 2^{\circ}$ do artigo $2^{\circ}$, da Lei 9784/99. Por isso, registra Di Pietro ${ }^{95}$ com relação ao princípio da indisponibilidade do interesse público:

Assim, a autoridade não pode renunciar ao exercício das competências que lhe são outorgadas por lei; não pode deixar de punir quando constate a prática de ilícito administrativo; não pode deixar de exercer o poder de polícia para coibir o exercício dos direitos individuais em conflito com o bem-estar coletivo; não pode deixar de exercer os poderes decorrentes da

\footnotetext{
91 ARAÚJO, Edmir Netto de. Curso de Direito Administrativo. 5. ed. revisada e atualizada. São Paulo: Saraiva, 2010. p. 74.

92 DI PIETRO, Maria Sylvia Zanella. Direito Administrativo. 25. ed. São Paulo:Atlas, 2012. p. 65-68.

93 MEIRELlES, Hely Lopes. Direito Administrativo Brasileiro. 33. ed. São Paulo: RT, 2007. p.103; DI PIETRO, Maria Sylvia Zanella. Direito Administrativo. 25. ed. São Paulo: Atlas, 2012. p. 65-68.

94 ARAÚJO, Edmir Netto de. Curso de Direito Administrativo. 5. ed. revisada e atualizada. São Paulo: Saraiva, 2010. p. 75.

95 DI PIETRO, Maria Sylvia Zanella. Direito Administrativo. 25. ed. São Paulo: Atlas, 2012. p. 67.
} 
hierarquia; não pode adotar qualquer postura de liberalidade com o dinheiro público. Cada vez que ela se omite no exercício de seus poderes, é o interesse público que está sendo prejudicado.

\subsubsection{Princípio do poder-dever}

Edmir Netto de Araújo ${ }^{96}$ afirma que os poderes funcionais da Administração "constituem [...] instrumentos para que o Estado possa fazer prevalecer efetiva e operacionalmente o interesse público, coletivo, sobre o particular individual" Com efeito, importante ressaltar que os agentes públicos se utilizam dos poderes funcionais, "como veículo para as atividades que à Administração são imputadas" - segundo Oswaldo Aranha Bandeira de Mello, citado por Edmir Netto de Araújo ${ }^{97}$ - e estas atuações são desempenhadas por servidores públicos que, para atender a seus deveres utilizam referidos poderes funcionais.

Poderes, aliás, considerados como "deveres" por Di Pietro ${ }^{98}$ e, destarte, não há que visualizar mera faculdade conferida ao administrador público e sim a atribuição de um poder - dever. Por isso são irrenunciáveis. Diante deste quadro, José Cretella Junior ${ }^{99}$ afirma: "[...] é o que se chama de poder - dever de tomar as providências que o caso exige, quando em jogo o interesse público [...]”.

\subsubsection{Princípio da igualdade - isonomia}

Princípio considerado corolário da justiça, a igualdade traduz a ideia de que todos são iguais perante a lei, sem distinção de qualquer natureza, o que no Direito Público ganha contornos especiais uma vez que a Administração só pode agir de acordo com a lei - princípio da restritividade - e no tocante aos administrados, mesmo desnivelados com relação à Administração, esses não poderão ser contemplados com tratamento diferente daqueles que se

96 ARAÚJO, Edmir Netto de. Curso de Direito Administrativo. 5. ed. revisada e atualizada. São Paulo: Saraiva, 2010. p. 457.

97 ARAÚJO, Edmir Netto de. Curso de Direito Administrativo. 5. ed. revisada e atualizada. São Paulo: Saraiva, 2010, p. 457.

98 DI PIETRO, Maria Sylvia Zanella. Direito Administrativo. 25. ed. São Paulo: Atlas, 2012. p. 90. 
encontram em situações jurídicas idênticas com relação à Administração. Aqui vale também a assertiva do tratamento desigual a casos desiguais na medida em que se desigualam.

O princípio da igualdade, conhecido também como o cânone da isonomia, vem esculpido nos próprios valores de justiça previstos em esfera constitucional, fincado no caput, do artigo $5^{\circ}$, da Constituição Federal de 1988. Produz reflexos relevantes no âmbito do Direito Administrativo, porquanto como aduz Edmir Netto de Araújo ${ }^{100}$ implica em que "[...] todos tenham o direito de, nas mesmas condições, ter as mesmas oportunidades e o mesmo tratamento legal pela Administração".

\subsubsection{Princípio da impessoalidade}

Previsto no caput, do artigo 37 da Constituição Federal, o conceito de impessoalidade decorre da ideia de que a imputação das funções ou tarefas públicas visa um órgão ou entidade competente para a prática do ato administrativo e não o agente ${ }^{101}$.

É possível, também, alinhá-lo ao princípio da finalidade, sempre tendo por norte o impedimento de se buscar, mediante ato administrativo, um interesse próprio, distante do interesse coletivo $^{102}$. E mais, pode estar relacionado com o princípio da isonomia, ou melhor, com o dever da Administração em tratar os administrados sem qualquer discriminação ou vantagem $^{103}$, o que nos induz ao raciocínio de que o princípio da impessoalidade previsto na Constituição Federal tem por escopo impedir atuações do Estado movidas por outro motivo senão o interesse coletivo e na exata medida deste.

Odete Medauar ${ }^{104}$ explicita que

Os princípios da impessoalidade, moralidade e publicidade apresentam-se intrincados de maneira profunda, havendo, mesmo, instrumentalização recíproca; assim, a impessoalidade configura-se meio para atuações dentro

100 ARAÚJO, Edmir Netto de. Curso de Direito Administrativo. 5. ed. revisada e atualizada. São Paulo: Saraiva, 2010. p. 77.

101 DI PIETRO, Maria Sylvia Zanella. Direito Administrativo. 25. ed. São Paulo:Atlas, 2012. p. 68-69; SILVA, José Afonso da. Curso de Direito Constitucional Positivo. São Paulo: RT, 1989. p. 562.b

102 MEIRELLES, Hely Lopes. Direito Administrativo Brasileiro. 33. ed. São Paulo: RT, 2007. p. 91-92.

103 BANDEIRA DE MELlo, Celso Antônio. Curso de Direito Administrativo. 29. ed. São Paulo: Malheiros, 2012. p. 117; FIGUEIREDO; Lucia Valle. Curso de Direito Administrativo. São Paulo: Malheiros, 2001. p. 61-62.

104 MEDAUAR, Odete. Direito Administrativo Moderno. São Paulo: Revista dos Tribunais, 2011. p. 132. 
da moralidade; a publicidade, por sua vez, dificulta medidas contrárias à moralidade e impessoalidade; a moralidade administrativa, de seu lado, implica observância da impessoalidade e da publicidade. Embora nem sempre seja possível afastar as implicações recíprocas desses princípios, o estudo em separado atende a requisitos didáticos.

\subsubsection{Princípio da moralidade administrativa}

O princípio da moralidade administrativa, topograficamente, também se situa no caput do já aludido artigo 37, da Constituição Federal, e mantém vínculo com o dever de honestidade e de lealdade que deve pautar a conduta do agente público em seu múnus público. Embora não seja, na sua essência, princípio de perfil jurídico, uma vez que claramente se posiciona mais próximo da ética e da moral, é de se observar que a Constituição Federal lhe acoplou status constitucional, o que lhe atribuiu um recorte jurídico.

E, no âmbito dessa conotação jurídica, afirma Edmir Netto de Araújo ${ }^{105}$ :

O agente verificará sobre o legal ou ilegal, adotando obrigatoriamente a primeira postura; sobre o oportuno ou conveniente decidirá dentro dos quadros da ordem jurídica; mas também o fará sobre o honesto ou desonesto, pois nem tudo que é legal, formalmente, é honesto ou moral. Às vezes, sob a capa da legalidade formal, acobertado pela competência legal e escondido da responsabilidade pela diluição desta entre vários funcionários, o agente poderá praticar ato que, por sua natureza, deveria perseguir, prevalecendo, nas sombras, o interesse pessoal, ilegítimo e inconfessável.

As leis disciplinadoras da Ação Popular (Lei nº 4.717/65), a Ação Civil Pública (Lei $n^{0}$ 7.347/85), a Lei da Improbidade do Agente Público (Lei $n^{\circ}$ 8.429/92), constituem instrumentos legais que o ordenamento jurídico, em esfera federativa, coloca à disposição do administrado, visando combater o desvio de idoneidade do servidor, no afã de preservar o patrimônio público.

Mas instigante é o registro de Edmir Netto de Araújo ${ }^{106}$ ao recordar que, por força de manifestações jurisprudenciais, a moralidade passa a se albergar no conceito de legalidade, aduzindo: "Por isso é que o Poder Judiciário já tem decidido que a moralidade administrativa e a conformação com o interesse público também integram o conceito de legalidade e

105 ARAÚJO, Edmir Netto de. Curso de Direito Administrativo. 5. ed. revisada e atualizada. São Paulo: Saraiva, 2010. p.79.

106 ARAÚJO, Edmir Netto de. Curso de Direito Administrativo. 5. ed. revisada e atualizada. São Paulo: Saraiva, 2010. p. 79. 
legitimidade do ato, ao lado do confronto com o modelo legal propiciando o controle judicial".

\subsubsection{Princípio da publicidade}

Previsto, a seu turno no abrangente caput, do artigo 37 da Constituição Federal, o princípio da publicidade encontra guarida, ainda, no artigo 111, da Constituição do Estado de São Paulo. Mas importante é incluir nesta base normativa o artigo 112, da Constituição Paulista e, também presente no texto da Constituição Federal, o preceito contido no $\S 1^{\circ}$, do mesmo artigo 37. São todos dispositivos que atuam como corolários do axioma da publicidade no nosso Direito. ${ }^{107}$ Vale ressaltar que a Lei $\mathrm{n}^{\mathrm{o}}$ 9.784/99, reguladora do processo administrativo no âmbito federal, no inciso IV, do Parágrafo único, do seu artigo $2^{\circ}$, prevê a divulgação oficial dos atos administrativos, ressalvadas as hipóteses de sigilo previstas na Constituição.

$$
\text { Ora, ensina Hely Lopes Meirelles }{ }^{108} \text { que }
$$

Publicidade é a divulgação oficial do ato para conhecimento público e início de seus efeitos externos. Daí porque as leis, atos e contratos administrativos, que produzem consequências jurídicas fora dos órgãos que os emitem, exigem publicidade para adquirirem validade universal, isto é, perante as partes e terceiros. A publicidade não é elemento formativo do ato; é requisito de eficácia e moralidade. Por isso mesmo, os atos irregulares não se convalidam com a publicação, nem os regulares a dispensam para sua exequibilidade, quando a lei ou o regulamento a exige.

Há que se distinguir publicidade geral da publicidade restrita. Aquela corresponde à “publicação, no órgão oficial (e não só na imprensa particular, embora esta não seja proibida e até mesmo exigida em certos casos), dos atos de efeitos gerais e externos, não se impedindo,

\footnotetext{
107 "Art. 37. A administração pública direta e indireta de qualquer dos Poderes da União, dos Estados, do Distrito Federal e dos Municípios obedecerá aos princípios de legalidade, impessoalidade, moralidade, publicidade e eficiência e, também, ao seguinte $[\ldots] \S 1^{\circ}$ - A publicidade dos atos, programas, obras, serviços e campanhas dos órgãos públicos deverá ter caráter educativo, informativo ou de orientação social, dela não podendo constar nomes, símbolos ou imagens que caracterizem promoção pessoal de autoridades ou servidores públicos. [...] Artigo 111 - A administração pública direta, indireta ou fundacional, de qualquer dos Poderes do Estado, obedecerá aos princípios de legalidade, impessoalidade, moralidade, publicidade, razoabilidade, finalidade, motivação, interesse público e eficiência. Artigo 112 - As leis e atos administrativos externos deverão ser publicados no órgão oficial do Estado, para que produzam os seus efeitos regulares. A publicação dos atos não normativos poderá ser resumida".
} 
todavia, (ao contrário, é até mais comum) a publicação de atos de efeitos internos e mesmo de individuais" indica Edmir Netto de Araújo ${ }^{109}$. A publicidade restrita se relaciona com aqueles atos cuja publicação se direciona ao conhecimento pessoal dos interessados diretos, por notificação, citação ou intimação.

Elucidativa, assim, a lição de Edmir Netto de Araújo ${ }^{110}$,

[...] primeiro: que os atos da Administração são públicos, como dissemos, salvo as exceções legais, no sentido do administrado, demonstrando legítimo interesse, deles tomar conhecimento a qualquer tempo a seu pedido, quando a publicidade geral não é exigida (atos de efeitos internos ou de caráter individual, p. ex); segundo, que é assegurado o direito, garantido pela Constituição (artigo $5^{\circ}$, XXXIV, b, da CF), de obtenção de certidões de atos, contratos e documentos, para defesa de direitos e esclarecimentos de situações de interesse pessoal (por isso deve ser demonstrado o legítimo interesse).

A publicidade é regra. A não publicidade é exceção e, como toda excepcionalidade, deve estar legalmente prevista e autorizada. Há que assinalar mais, os limites estão definidos no inciso XXXIII, do artigo $5^{\circ}$, da Constituição Federal de 1988, que arrola os casos em que o sigilo seja imprescindível à segurança da sociedade ou do Estado, excerto disciplinado pela Lei Federal $\mathrm{n}^{\circ}$ 12.527/11, a denominada Lei da Transparência Pública, sendo esta, por sua vez, regulamentada pelo Decreto ${ }^{\circ} 7.727 / 12$.

O diploma (a Lei da Transparência Pública ${ }^{111}$ ) registra o caráter de exceção do sigilo e preordena a publicidade como regra ao preconizar no inciso I, do seu artigo $3^{\circ}$ que os procedimentos previstos no referido texto destinam-se a assegurar o direito fundamental de acesso à informação e devem ser executados em conformidade com os princípios básicos da administração pública. E ainda estabeleceu como diretrizes: a observância da publicidade como preceito geral e do sigilo como exceção.

O princípio da publicidade permite o conhecimento e o controle dos atos administrativos pela sociedade, que pode guerrear eventuais atos ilegais por intermédio dos institutos previstos na Constituição Federal de 1988, por exemplo, o mandado de segurança, o

\footnotetext{
109 ARAÚJO, Edmir Netto de. Curso de Direito Administrativo. 5. ed. revisada e atualizada. São Paulo: Saraiva, 2010. p. 80.

110 ARAÚJO, Edmir Netto de. Curso de Direito Administrativo. 5. ed. revisada e atualizada. São Paulo: Saraiva, 2010. p. 80-81.

111 Lei 12.527, de 18 de novembro de 2011 - Regula o acesso a informações previsto no inciso XXXIII do art. 5으, no inciso II do $\S 3 \underline{\mathrm{O}}$ do art. 37 e no $\S 2 \underline{\mathrm{o}}$ do art. 216 da Constituição Federal; altera a Lei n $\underline{\mathrm{O}}$ 8.112, de 11 de dezembro de 1990; revoga a Lei no 11.111 , de 5 de maio de 2005, e dispositivos da Lei no 8.159, de 8 de janeiro de 1991; e dá outras providências.
} 
direito de petição, a ação popular, o habeas data, o direito de certidão, respectivamente sacramentados nos incisos LXIX, XXXIV, “a”, LXXIII, LXXII, XXXIV, “b”, do artigo 5, da Constituição Federal de 1988. Alinhando-se a, essas ferramentas de controle, a possibilidade preconizada no $\S 4^{\circ}$, do artigo 37, da Constituição Federal, de apurar e decretar o afastamento de autoridades por improbidade administrativa.

A publicação dos atos, portanto, conclui Edmir Netto de Araújo ${ }^{112}$, “[...] destinase também ao controle da legalidade das atividades administrativas e, em consequência, à defesa de direitos ou de interesses dos administrados". A ela, reafirma o autor, deve ser atribuída a viabilização de eventual impugnação e, na hipótese de inobservância, avulta mesmo a nulidade dos atos praticados pela autoridade.

\subsubsection{Princípio da eficiência}

O Princípio da eficiência, conhecido, ainda, como princípio da boa administração ${ }^{113}$, marca presença, de sua parte, no preceito constante do caput, do artigo 37, da Constituição Federal. Foi inserido pela EC 19/98, a denominada reforma administrativa e, em seguida, reafirmado pela Lei $\mathrm{n}^{\circ} 9.784 / 99$, que regula o processo administrativo em âmbito federal (caput, do artigo $2^{\circ}$ desse texto).

A Constituição Paulista, a seu turno, o prevê no rol fixado no artigo 111 e a Lei Orgânica do Município de São Paulo, datada de 1990, por força de emenda, de seu lado, o estabeleceu no Parágrafo único, do seu artigo 123, regra que garante ao usuário o serviço público compatível com sua dignidade humana, prestado com eficiência e outras virtudes.

\section{Di Pietro ${ }^{114}$ afirma que}

O princípio da eficiência apresenta, na realidade, dois aspectos: pode ser considerado em relação ao modo de atuação do agente público, do qual se espera o melhor desempenho possível de suas atribuições, para lograr os melhores resultados; em relação ao modo de organizar, estruturar,

112 ARAÚJO, Edmir Netto de. Curso de Direito Administrativo. 5. ed. revisada e atualizada. São Paulo: Saraiva, 2010. p. 81.

113 O autor, citando Guido Falzoni, discorre no sentido de o princípio da eficiência ser uma faceta de um princípio mais amplo já superiormente tratado, de há muito, no Direito italiano: o princípio da boa administração. BANDEIRA DE MELLO, Celso Antônio. Curso de Direito Administrativo. 29. ed. São Paulo: Malheiros, 2012. p. 125.

114 DI PIETRO, Maria Sylvia Zanella. Direito Administrativo. 25. ed. São Paulo: Atlas, 2012.p. 84. 
disciplinar a Administração Pública, também com o mesmo objetivo de alcançar os melhores resultados na prestação do serviço público.

Alertam Odete Medauar ${ }^{115}$ e Di Pietro para o entendimento errôneo do princípio da eficiência com relação à legalidade. É que o princípio da eficiência deve ser interpretado em harmonia com os demais axiomas do Direito Administrativo, não derrogando nenhum em especial, principalmente um dos fundamentais pilares da ideia de Estado de Direito, isto é, a legalidade, que deve ser resguardada em qualquer hipótese.

\subsubsection{Princípio da razoabilidade e proporcionalidade}

O princípio da razoabilidade é axioma expressamente previsto no artigo 111, da Constituição Paulista, bem como no artigo $2^{\circ}$, Parágrafo único, inciso VI, da já aludida Lei ${ }^{\circ}$ 9.784/99, texto esse que faz referência aos princípios da razoabilidade e da proporcionalidade.

Celso Antônio Bandeira de Mello ${ }^{116}$ relaciona o princípio da razoabilidade com os cânones da legalidade (artigo 5º II, 37 e 84 da Constituição Federal) e da finalidade pública (os mesmos somados ao artigo $5^{\circ}$, LXIX). Desses dois princípios extrai o jurista o fundamento de sua validade, considerando que a aplicação da razoabilidade tem o escopo de conter o arbítrio administrativo mediante a limitação da discricionariedade administrativa, dirige-se à própria atividade do legislador e amplia a possibilidade de controle pelo poder Judiciário ao apreciar o ato administrativo.

É, ainda, Celso Antônio Bandeira de Mello ${ }^{117}$ que analisa a característica histórica dos princípios da proporcionalidade e da razoabilidade, ponderando que enquanto a proporcionalidade tem sua origem no sistema romano-germânico como opção para coibir o arbítrio, a razoabilidade é noção mais comum no sistema da common law. Em seu entendimento, todavia, a proporcionalidade representa uma faceta da razoabilidade, embora não se confundam inteiramente. Para o autor, o princípio da proporcionalidade, ainda que faceta da razoabilidade,

115 MEDAUAR, Odete. Direito Administrativo Moderno. São Paulo: Revista dos Tribunais, 2011. p. 137; DI PIETRO, Maria Sylvia Zanella. Direito Administrativo. 25. ed. São Paulo: Atlas, 2012. p. 84-85.

116 BANDEIRA DE MELlo, Celso Antônio. Curso de Direito Administrativo. 29. ed. São Paulo: Malheiros, 2012. p. 111-112.

117 BANDEIRA DE MELlo, Celso Antônio. Curso de Direito Administrativo. 29. ed. São Paulo: Malheiros, 2012. p. 114. 
Merece um destaque próprio, uma referência especial, para ter-se maior visibilidade da fisionomia específica de um vício que pode surdir e entremostrar-se sob esta feição de desproporcionalidade do ato, salientandose, destarte, a possibilidade de correção judicial arrimada neste fundamento. ${ }^{118}$

Do mesmo sentir, Hely Lopes Meirelles ${ }^{119}$ afirma que os princípios da razoabilidade e proporcionalidade consistem na proibição do excesso e, além de estarem previstos expressamente na Carta Paulista e na Lei $\mathrm{n}^{\circ}$ 9.784/99, estão implícitos na Constituição Federal. Por isto assegura que "[...] A norma ou ato que se revela desarrazoado por ferir a proporcionalidade ofende o princípio do devido processo legal em sentido material, previsto no artigo $5^{\circ}$, LIV, da CF [...]". Para Hely Lopes Meirelles ${ }^{120}$, o princípio da proporcionalidade está inserido na razoabilidade e vice-versa, e, no que concerne ao conceito, ensina que "Sem dúvida, pode ser chamado de princípio de proibição de excesso, que em última análise, objetiva aferir a compatibilidade entre os meios e os fins, de modo a evitar restrições desnecessárias ou abusivas por parte da Administração Pública, com lesão aos direitos fundamentais".

Di Pietro ${ }^{121}$ entende que o princípio da proporcionalidade constitui um dos aspectos previstos no princípio da razoabilidade. Para tanto expõe:

Isto porque o princípio da razoabilidade, entre outras coisas, exige proporcionalidade entre os meios de que se utiliza a Administração e os fins que ela tem que alcançar. E essa proporcionalidade deve ser medida não pelos critérios pessoais do administrador, mas segundo padrões comuns na sociedade em que vive; e não pode ser medida diante dos termos frios da lei, mas diante do caso concreto.

Edmir Netto de Araújo ${ }^{122}$ afirma que o elemento proporcionalidade integra o conceito do princípio da razoabilidade, o que nos parece uma posição conceitual mais objetiva. Diverge, no entanto, da visão que entende a proporcionalidade como consequência da razoabilidade, definindo a razoabilidade como "[...] o desbordar da liberdade dentro da lei que é característica dos atos administrativos discricionários, quando a medida é

\footnotetext{
118 BANDEIRA DE MELlo, Celso Antônio. Curso de Direito Administrativo. 29. ed. São Paulo: Malheiros, 2012. p. 114.

119 MEIRELLES, Hely Lopes. Direito Administrativo Brasileiro. 33. ed. São Paulo: RT, 2007. p. 92, nota de rodapé $\mathrm{n}^{\mathrm{o}} 52$.

120 MEIRELlES, Hely Lopes. Direito Administrativo Brasileiro. 33. ed. São Paulo: RT, 2007. p.93.

121 DI PIETRO, Maria Sylvia Zanella. Direito Administrativo. 25. ed. São Paulo:Atlas, 2012. p. 80-82.

122 ARAÚJO, Edmir Netto de. Curso de Direito Administrativo. 5. ed. revisada e atualizada. São Paulo: Saraiva, 2010. p. 81.
} 
desproporcional ou inadequada ao fim de interesse público concretamente existente, o que é mais fácil verificar se o agente externar as razões do ato (motivar)". Conclui o autor que, "Na realidade, o princípio da razoabilidade traduz a congruência lógica entre o fato (o motivo) e atuação concreta da Administração". ${ }^{123}$

\subsubsection{Princípio da responsabilidade do Estado}

Por longo período, o tema atinente à responsabilidade do Estado restou sob o domínio das teorias regalianas e civilistas. Hoje, a teoria publicista da responsabilidade objetiva é a que prevalece, erigida a status constitucional pelo Texto Fundamental de 1988. O $\S 6^{\circ}$, do artigo 37, da Constituição acaba autorizando a responsabilização do Estado pela simples prestação do serviço defeituoso, importando o mero nexo causal e não demandando a comprovação de culpa por parte do administrado.

Funda-se no risco que a prestação dos serviços públicos gera. Exclui-se a responsabilidade do Poder apenas se ficar demonstrada a culpa da vítima, caso fortuito, força maior ou ausência de nexo de causalidade entre o dano e o prejuízo, hipóteses que demandam comprovação cujo ônus é do Estado. Daí porque a responsabilidade do Estado pode se dar por ato lícito ${ }^{124}$ e em caso de omissão ${ }^{125}$.

A teoria encontra respaldo na ideia de "solidariedade social", segundo a qual a todos compete contribuir para a reparação dos danos causados pela atividade administrativa. É adotada no Brasil desde a Constituição de 1946. Abrange tanto as pessoas jurídicas de direito público, como também as pessoas jurídicas de direito privado que prestem serviço público.

Nas palavras de Elcio Trujillo,

A responsabilidade objetiva não considera existência da culpa e tem por base essencial e indispensável para a sua imputação junto ao ente público, a existência do nexo causal entre a atividade motivadora da lesão e o evento danoso, incluindo, por consequência, as obrigações decorrentes. Busca-se uma base teórica que sustente a imputação da responsabilidade ao Estado, dispensando o exame da culpabilidade de agentes ou serviços, mas

\footnotetext{
123 ARAÚJO, Edmir Netto de. Curso de Direito Administrativo. 5. ed. revisada e atualizada. São Paulo: Saraiva, 2010. p.82.

124 TRUJILlo, Elcio. Responsabilidade do Estado por Ato Lícito. São Paulo: Editora de Direito, 1996.

125 ARAÚJO, Edmir Netto de. Curso de Direito Administrativo. 5. ed. revisada e atualizada. São Paulo: Saraiva, 2010. p. 811-812.
} 
permitindo, dada a abrangência, assumir todas as situações que se apresentam na complexa relação jurídica existente, bem como delimitação dos danos que o Estado deve ressarcir ao particular. ${ }^{126}$

Odete Medauar ressalta que há princípios a servir de base para a consolidação da ideia de responsabilidade objetiva do Estado e explana:

Em primeiro lugar, o próprio sentido de justiça (equidade), [...], que permeia o direito e a própria vida, em virtude do qual o causador de prejuízo a outrem fica obrigado a reparar o dano. No caso da Administração, a multiplicidade e amplitude de suas atividades e as suas prerrogativas de poder ensejam risco maior de danos a terceiros. Por outro lado, nem sempre é possível identificar o agente causador, nem sempre é possível demonstrar seu dolo ou culpa. Melhor se asseguram os direitos da vítima ante o tratamento objetivo da responsabilidade da Administração. Em segundo lugar, o preceito da igualdade de todos ante o ônus e encargos da Administração, também denominado 'solidariedade social': se, em tese, todos se beneficiam das atividades da Administração, todos (representados pelo Estado) devem compartilhar do ressarcimento dos danos que essas atividades causam a alguns. ${ }^{127}$

\subsubsection{Presunção de legitimidade, imperatividade e autoexecutoriedade}

Constituem caracteres específicos a envolver os atos da Administração Pública. Edmir Netto de Araújo ${ }^{128}$, integrando importante linha doutrinária ${ }^{129}$, considera essas características genéricas dos atos Administrativos, ou ao menos algumas delas, como princípios do Direito Administrativo.

Referidas conotações, aliás, são por vezes analisadas sob a denominação de "atributos" $" 130$ ou de "notas peculiares do ato administrativo"131, vinculando-se a fatores gerais

\footnotetext{
126 TRUJILLO, Elcio. Responsabilidade do Estado por Ato Lícito. São Paulo: Editora de Direito, 1996. p. 123.

127 MEDAUAR, Odete. Direito Administrativo Moderno. São Paulo: RT, 2011. p. 389.

128 ARAÚJO, Edmir Netto de. Curso de Direito Administrativo. 5. ed. revisada e atualizada. São Paulo: Saraiva, 2010. p. 83.

129 FIGUEIREDO; Lucia Valle. Curso de Direito Administrativo. São Paulo: Malheiros, 2001. p. 171- 172 e 175-176; JÚNIOR, José Cretella. Direito Administrativo Brasileiro. Rio de Janeiro: Forense, 1983. p. 21, 30 e 41 (vol.1); MOREIRA NENETO, Diogo de Figueiredo. Curso de Direito Administrativo. Rio de Janeiro: Forense, 1989. p. 73 e 81.

130 MEIRELLES, Hely Lopes. Direito Administrativo Brasileiro. 33. ed. São Paulo: RT, 2007. p. 159-162.

131 MEDAUAR, Odete. Direito Administrativo Moderno. São Paulo: Revista dos Tribunais, 2011. p. 150.
} 
de eficácia dos atos administrativos, conforme aduz Edmir Netto de Araújo ${ }^{132}$. E, na verdade, as diretrizes desses princípios decorrem da supremacia do interesse público sobre o privado.

Assim, a imperatividade é a característica do ato administrativo em impor os seus comandos a todos os que na hipótese se enquadrarem. De sua parte, a presunção de legitimidade consiste na virtude de validade do ato administrativo até prova definitiva em contrário. E a autoexecutoriedade é a qualidade de imediata eficácia do ato independente da declaração de qualquer outro ente ou dos administrados.

\subsubsection{Princípio do controle jurisdicional}

Entre nós, vigora o modelo da jurisdição administrativa herdada do sistema anglosaxão, isto é, una lex, una jurisdictio, esculpida no inciso XXXV, do artigo $5^{\circ}$, da Constituição Federal vigente. Destarte, como assevera o administrativista Edmir Netto de Araújo, “[...] o sistema constitucional brasileiro repele a possibilidade da existência da jurisdição dúplice, cujo instituto característico é o contencioso administrativo, tal como ele é entendido na França, Bélgica, Portugal e outros países que o adotam". ${ }^{133}$

Assim, hoje no Brasil, aplica-se em sede de Direito Administrativo o exercício da jurisdição caracterizado pela unicidade, sendo conferida a competência para a apreciação dos conflitos ao Poder Judiciário, que tem por cúpula o Supremo Tribunal Federal. Na sua organização, o Judiciário reserva Varas especializadas para a apreciação das causas em que o Estado seja parte. Em nível federal, as Varas e Tribunais da Justiça Federal e, no âmbito regional, a Justiça Estadual que conta na sua estrutura com as chamadas Varas da Fazenda Pública e a novel Lei dos Juizados de Pequenas Causas da Fazenda Pública, Lei n ${ }^{\circ} 12.153$, de dezembro de $2009^{134}$.

\footnotetext{
132 ARAÚJO, Edmir Netto de. Curso de Direito Administrativo. 5. ed. revisada e atualizada. São Paulo: Saraiva, 2010. p. 83.

133 ARAÚJO, Edmir Netto de. Curso de Direito Administrativo. 5. ed. revisada e atualizada. São Paulo: Saraiva, 2010. p. 1281.
}

134 Segundo a Lei em vigor: "Não se encaixam na competência do Juizado Especial da Fazenda Pública: ações de mandado de segurança, de desapropriação, de divisão e demarcação, populares, por improbidade administrativa, execuções fiscais e as demandas sobre direitos ou interesses difusos e coletivos; causas sobre bens imóveis dos Estados, Distrito Federal, Territórios e Municípios, autarquias e fundações públicas a eles vinculadas; causas que tenham como objeto a impugnação da pena de demissão imposta a servidores públicos civis ou sanções disciplinares aplicadas a militares; ações que tenham como fundamento qualquer penalidade decorrente de infrações de trânsito (multas, pontuação, apreensão de veículos etc.); qualquer demanda 


\subsubsection{Princípio da autotutela}

Di Pietro" 135 afirma que "Enquanto pela tutela a Administração exerce controle sobre outra pessoa jurídica por ela mesma instituída, pela autotutela o controle se exerce sobre os próprios atos, com a possibilidade de anular os ilegais e revogar os inconvenientes ou inoportunos, independentemente de recurso ao poder Judiciário".

O poder da Administração em invalidar seus próprios atos, sujeitando-se a controle próprio, sem a participação do Poder Judiciário, é decorrência do axioma da legalidade, vindo a ser consagrado por intermédio de duas memoráveis súmulas expedidas pelo E. Supremo Tribunal Federal: STF Súmula n 473 - A administração pode anular seus próprios atos, quando eivados de vícios que os tornam ilegais, porque deles não se originam direitos; ou revogá-los, por motivo de conveniência ou oportunidade, respeitados os direitos adquiridos, e ressalvada, em todos os casos, a apreciação judicial; e STF Súmula no 346 - A administração pública pode declarar a nulidade dos seus próprios atos.

Relevante o registro da observação de Di Pietro ${ }^{136}$, no sentido de que é viável referir-se à autotutela, também, para “[...] designar o poder que tem a Administração Pública de zelar pelos bens que integram o seu patrimônio, sem necessitar de título fornecido pelo poder Judiciário. Ela pode por meio de medidas de polícia administrativa, impedir quaisquer atos que ponham em risco a conservação desses bens".

\subsubsection{Princípio da discricionariedade}

A doutrina contemporânea, como assevera Edmir Netto de Araújo ${ }^{137}$, citando a professora Di Pietro, aponta a discricionariedade, de que goza o Estado no exercício de suas funções, como “[...] a faculdade que a lei confere à Administração para apreciar o caso

envolvendo créditos de natureza fiscal; ações previdenciárias (art. 109, parágrafo $3^{\circ}$, da CF/88)" (Disponível em: $<$ http://www.tjsp.jus.br/ > . Acesso em: 15 set. 2012).

135 DI PIETRO, Maria Sylvia Zanella. Direito Administrativo. 25. ed.São Paulo: Atlas, 2012. p. 70.

136 DI PIETRO, Maria Sylvia Zanella. Direito Administrativo. 25. ed. São Paulo: Atlas, 2012. p. 70.

137 ARAÚJO, Edmir Netto de. Curso de Direito Administrativo. 5. ed. revisada e atualizada. São Paulo: Saraiva, 2010. p. 489. 
concreto, segundo critérios de oportunidade e conveniência e escolher entre duas ou mais soluções, todas válidas perante o direito".

Importante registrar que, na origem, a teoria de vinculação da Administração à lei resultava da nítida desconfiança em conferir à Administração qualquer liberdade de atuação. A vinculação era entendida como equivalente à legalidade estrita.

No entanto, apesar da evolução da teoria da vinculação da Administração à lei, o aparecimento da discricionariedade passou a conferir ao Poder Executivo uma ampla liberdade e, portanto, fora do alcance de qualquer tipo de controle. É evidente que tal concepção não prospera nos dias atuais, sobretudo com a atual abrangência do próprio conceito de legalidade no nosso ordenamento jurídico em vigor.

Nesse sentido, Odete Medauar ${ }^{138}$ entende, igualmente, que

Hoje, no âmbito de um estado de direito, é impossível cogitar-se de poder discricionário fora do direito, subtraído a toda disciplina legal. $\mathrm{Na}$ contraposição poder vinculado-poder discricionário, o primeiro corresponderia às matérias de reserva legal absoluta e o segundo, a matérias de reserva legal relativa.

Complementa Medauar ${ }^{139}$, “A autoridade, ao exercer o poder discricionário, deve atender ao interesse público referente à competência que lhe foi conferida, por isso a escolha que realiza é finalística".

Celso Antônio Bandeira de Mello ${ }^{140}$ anota que a discricionariedade pode decorrer da hipótese da norma, isto é, do modo impreciso com que a lei haja descrito a situação fática ou conceitos imprecisos contidos na respectiva norma, sendo que apresenta como solução a busca pela finalidade da norma.

Ensina Celso Antônio Bandeira de Mello $^{141}$ que a discricionariedade também poderá resultar do comando da norma. Isso quando para o agente administrativo a norma vier (a) a abrir alternativas de conduta, seja agir ou omitir-se, apreciar a oportunidade adequada; (b) a outorgar liberdade quanto à forma jurídica; (c) a atribuir competência para a adoção da medida mais satisfatória perante as circunstâncias, em prol da melhor solução; Por derradeiro, ressalta a finalidade da norma, como fonte da discricionariedade administrativa.

\footnotetext{
138 MEDAUAR, Odete. Direito Administrativo Moderno. 15. ed. São Paulo: RT, 2011. p. 118.

139 MEDAUAR, Odete. Direito Administrativo Moderno. 15. ed. São Paulo: RT, 2011. p. 118.

140 BANDEIRA DE MELLO, Celso Antônio. Discricionariedade e Controle Jurisdicional. São Paulo: Malheiros, 2007. p. 22

141 BANDEIRA DE MELLO, Celso Antônio. Discricionariedade e Controle Jurisdicional. São Paulo: Malheiros, 2007. p. 22.
} 
Indaga-se, ademais, qual a natureza da discricionariedade? Para Celso Antônio Bandeira de Mello ${ }^{142}$, corresponde a "[...] pura e simplesmente o resultado da impossibilidade da mente humana poder saber sempre, em todos os casos, qual a providência que atende com precisão capilar a finalidade da regra do direito".

Com relação à discricionariedade presente no âmbito dos elementos do ato administrativo, ressalta-se que referido instituto permeia todos os elementos do ato, estando em maior ou menor grau de vinculação, dependendo justamente da característica da norma, que, por sua vez, está relacionada com seu conteúdo e finalidade.

Por fim, conclui-se que o mau uso da discricionariedade resta de difícil análise teórica dependendo muito do caso concreto. Mas forçoso é convir que os parâmetros de legalidade, ainda que diante da discricionariedade administrativa, não deixam de ser a legalidade em sentido amplo, cabendo, inclusive, apreciação do Poder Judiciário.

\subsection{OS PRINCÍPIOS ESPECÍfICOS QUE REGEM O PROCESSO ADMINISTRATIVO}

Certamente, os princípios gerais do Direito Administrativo, tanto aqueles previstos expressamente na Constituição Federal de 1988, quanto os implícitos, que decorrem da interpretação sistemática de seu texto, bem como aqueles estabelecidos em legislação infraconstitucional, aplicam-se, também, ao processo administrativo. É que alcançam toda a ciência do Direito Administrativo, nicho que alberga o processo administrativo. Somam-se, destarte, aos princípios setoriais específicos, objeto desta seção, como parâmetros axiológicos aplicáveis ao instituto do processo administrativo.

Importante registrar que, no presente tópico, serão abordados os princípios gerais do processo administrativo, preconizados tanto na Constituição Federal de 1988, como, ainda, em legislação específica e os consolidados por força da doutrina e da jurisprudência e que se estendem sobre todo o processo administrativo, norteando o seu desenvolvimento e servindo de guia normativo, independente da segmentação específica do processo administrativo.

Releva informar que o exame do elenco de princípios atinentes ao processo administrativo, foco da análise, foi realizado a partir do exame da doutrina e da

142 BANDEIRA DE MELLO, Celso Antônio. Discricionariedade e Controle Jurisdicional. São Paulo: Malheiros, 2007. p. 41. 
jurisprudência. Concluiu-se, nesta etapa, que seria interessante a sua apresentação em consonância com a preponderância de cada um destes standards, ainda porque o rol dos princípios do processo administrativo difere de autor para autor ${ }^{143}$, de acordo com o entendimento de cada um, a especificidade do processo administrativo em apreço e a legislação objeto de estudo.

No entanto, a tentativa de elaborar um rol de princípios setoriais gerais do processo administrativo afigura-se impositiva, considerando que em nosso ordenamento jurídico os princípios, além de previsões de intenção, são positivados em textos legais e funcionam como vetores de interpretação. Nesse sentido, terão a função de assegurar os objetivos e a finalidade do processo administrativo em nosso sistema jurídico comandado pelo cânone maior do Estado Democrático de Direito.

$$
\text { Ferraz e Dallari }{ }^{144} \text { afirmam que }
$$

O Processo administrativo tem dois objetivos fundamentais: (1) disciplinar, conferindo transparência e objetividade, os meios pelos quais a Administração Pública, por intermédio de seus agentes, toma decisões; e (2) assegurar o respeito a todos os atributos da cidadania no relacionamento entre a Administração e os administrados, inclusive seus próprios agentes.

Nesse diapasão, propõe-se, num primeiro momento, o exame - no ordenamento pátrio - dos princípios condutores do processo administrativo previstos na Constituição Federal de 1988, quais sejam, a ampla defesa e o contraditório (inciso LV, do artigo $5^{\circ}$ ), a duração razoável do processo (inciso LXXVIII, do artigo $5^{\circ}$ ), introduzido pela Emenda Constitucional 45, de 09 de dezembro de 2004, e o princípio do devido processo legal (inciso LIV, do artigo $5^{\circ}$ ), merecendo este último abordagem de forma isolada e peculiar, em razão de sua importância.

Não serão ignorados, ainda, os princípios do formalismo moderado, da oficialidade e da verdade material, da gratuidade, da boa-fé, da pluralidade de instâncias, estes

\footnotetext{
143 BANDEIRA DE MELlo, Celso Antônio. Curso de Direito Administrativo. 29. ed. São Paulo: Malheiros, 2012. p. 509-531; MEIRELLES, Hely Lopes. Direito Administrativo Brasileiro. 33. ed. São Paulo:RT, 2007. p. 687-690; DI PIETRO, Maria Sylvia Zanella. Direito Administrativo. 25. ed. São Paulo: Atlas, 2012. p. 682-693; MEDAUAR, Odete. Direito Administrativo Moderno. 15. ed. São Paulo: RT, 2011. p. 178-183; MEDAUAR, Odete. A Processualidade no Direito Administrativo. 2. ed. São Paulo: Revista dos Tribunais, 2008. p. 101-133; FERRAZ, Sérgio; DALLARI, Adilson Abreu. Processo Administrativo. São Paulo: Malheiros, 2001. p. 52-89; CINTRA, Antônio Carlos de Araújo; GRINOVER, Ada Pellegrini; DINAMARCO, Cândido R. Teoria Geral do Processo. 27. ed. São Paulo: Revista dos Tribunais, 2011. p. 56-83; SIMÕES, Mônica Martins Toscano. O Processo Administrativo e a Invalidação de Atos Viciados. São Paulo: Malheiros, 2004. p. 83-105.
} 
decorrentes da doutrina e da jurisprudência, máximas que, a seu turno mereceram expressão no âmbito da Lei $\mathrm{n}^{\circ}$ 9.784/99, que regula o processo administrativo em âmbito federal.

\subsubsection{Princípio do Contraditório}

O princípio do contraditório encontra expressa guarida no inciso $\mathrm{LV}$, do artigo $5^{\circ}$, da Constituição Federal de 1988, posicionando-se ao lado do princípio da ampla defesa. É preconizado também pela Lei $n^{\circ} 9.784 / 99$, no seu artigo $2^{\circ}$. O princípio do contraditório é originário do standard do devido processo legal, hoje previsto de forma clara no nosso Texto Fundamental, conforme disposto no artigo $5^{\circ}$, inciso LIV, cláusula originária do sistema da common law e que será melhor analisada no item subsequente.

Significativa a lição de Ada Pellegrini Grinover ${ }^{145}$ que o define como sendo a possibilidade de "tecnicamente contradizer a posição contrária". Odete Medauar ${ }^{146}$ recorda que a doutrina, já há tempos, vem identificando o contraditório no binômio informaçãoreação, sendo certo que, em relação ao primeiro, há necessidade de sua ocorrência. Quanto à reação, é preconizada a possibilidade, uma vez que se pode optar por realizá-la ou não. Aduz a autora ${ }^{147}$ que o contraditório é elemento ínsito para caracterizar o processo, pois propicia aos sujeitos do processo a ciência de dados, fatos, argumentos, documentos, a cujos teores pode reagir contando com mecanismos semelhantes.

Sintetizando o conceito do contraditório, optam Cintra, Grinover e Dinamarco ${ }^{148}$ em apresentar os fatores componentes, indigitando: “[...] dois elementos: (a) informação; (b) reação (esta, meramente possibilitada nos casos de direito disponíveis)”.

Ferraz e Dallari ${ }^{149}$ ensinam que

\footnotetext{
145 GRINOVER, Ada Pellegrini. Garantias do contraditório e ampla defesa. In: Jornal do Advogado, Seção de São Paulo, n. 175, p. 9, nov.1990.

146 MEDAUAR, Odete. A Processualidade no Direito Administrativo. 2. ed. São Paulo: Revista dos Tribunais, 2008. p. 101.

147 MEDAUAR, Odete. A Processualidade no Direito Administrativo. 2. ed. São Paulo: Revista dos Tribunais, 2008. p.102.

148 CINTRA, Antônio Carlos de Araújo; GRINOVER, Ada Pellegrini; DINAMARCO, Cândido R. Teoria Geral do Processo. 27. ed. São Paulo: Revista dos Tribunais, 2011. p. 63. 
A instrução do processo deve ser contraditória. Isso significa [acentuam os autores] que não basta que a Administração Pública, por sua iniciativa e por seus meios, colha os argumentos ou provas que lhe pareçam significativos para a defesa dos interesses do particular. É essencial que, ao interessado ou acusado, seja dada a possibilidade de produzir suas próprias razões e provas $\mathrm{e}$, mais que isso, que lhe seja dada a possibilidade de examinar e contestar os argumentos, fundamentos e elementos probantes que lhe sejam desfavoráveis.

Concluem os autores que: "Em síntese, o princípio do contraditório determina que a parte seja efetivamente ouvida e que seus argumentos sejam efetivamente considerados no julgamento".

A análise do contraditório, no âmbito do processo administrativo, suscita delicada questão atinente à denominação das partes. Odete Medauar ${ }^{150}$ afirma que no direito pátrio há certa resistência pela denominação de parte tanto em relação à Administração quantos aos outros figurantes. O Poder público está sempre presente sob a denominação de "Administração" e as outras partes sob diversas rubricas, a exemplo de candidato, contribuinte etc. A designação atribuída, em verdade, está ligada com a peculiaridade do processo administrativo e sua finalidade. Quando não se tem uma participação efetiva do ponto de vista do contraditório, costuma-se se denominar como interessado.

Para tanto, elucidativo o magistério de Cintra, Grinover e Dinamarco ${ }^{151}$, no que tange à utilização da expressão "sujeitos do processo", para denominar os participantes do processo administrativo. Parece-nos, ademais, a mais acertada, porquanto a par de expressar com clareza a condição das partes no âmbito do processo administrativo, indica que esses são sujeitos de direitos, obrigações, garantias e ônus.

Aliás, significativa a lição de Ada Pellegrini Grinover ${ }^{152}$, abordando os princípios da ampla defesa e do contraditório para ressaltar como

[...] inquestionável que é do contraditório que brota a própria defesa. [...] não há como negar que o conhecimento, ínsito no contraditório, é pressuposto para o exercício de defesa. Mas de outro ponto de vista, é igualmente válido afirmar que a defesa é que garante o contraditório, conquanto nele se manifeste. [...].

\footnotetext{
150 MEDAUAR, Odete. A Processualidade no Direito Administrativo. 2. ed. São Paulo: Revista dos Tribunais, 2008. p. 105-107.

151 CINTRA, Antônio Carlos de Araújo; GRINOVER, Ada Pellegrini; DINAMARCO, Cândido R. Teoria Geral do Processo. 27. ed. São Paulo: Revista dos Tribunais, 2011. p. 318.

152 GRINOVER, Ada Pellegrini. Novas Tendências do Direito Processual. Rio de Janeiro: Forense Universitária, 1990. p. 4-6.
} 
Do mesmo sentir, Odete Medauar ${ }^{153}$ realça o fato de que, por conta de tamanha interconexão, existente entre ambos os princípios, resta difícil considerar separadamente de forma precisa as peculiaridades teóricas e práticas dos institutos, embora existam.

Partindo, pois, dessas observações, recorremos aos apontamentos de Di Pietro ${ }^{154}$, que reafirma a íntima ligadura entre os dois princípios, explicitando:

O princípio do contraditório, que é inerente ao direito de defesa, é decorrente da bilateralidade do processo: quando uma das partes alega alguma coisa, há de ser ouvida também a outra, dando-se-lhe oportunidade de resposta. Ele supõe o conhecimento dos atos processuais pelo acusado e o seu direito de resposta ou de reação. Exige: 1. notificação dos atos processuais à parte interessada; 2 possibilidade de exame das provas constantes do processo; direito de assistir à inquirição de testemunhas; direito de apresentar defesa escrita.

\subsubsection{Princípio da Ampla Defesa}

O princípio da ampla defesa, como já registrado, é previsto expressamente no inciso LV, do artigo $5^{\circ}$, da nossa Lei Fundamental, ao lado do princípio do contraditório, encontrando-se preconizado, também, no artigo $2^{\circ}$, da Lei ${ }^{\circ}$ 9.784/99, anteriormente referida. O princípio, a exemplo do contraditório, traduz axioma geral de Direito e é originário do cânone do devido processo legal. Este sim encontra sua certidão de nascimento na common Law.

Hely Lopes Meirelles ${ }^{155}$ afirma que “[...] por garantia de defesa deve-se entender não só a observância do rito adequado como a cientificação do seu direito, o acompanhar dos atos da instrução e utilizar-se dos recursos cabíveis. [...]”.

Odete Medauar ${ }^{156}$ elenca como desdobramentos da ampla defesa no processo administrativo: (a) a questão do caráter prévio da defesa, que representa óbice à verdade sabida como critério de punição; (b) o direito de interpor recurso administrativo (este que independe de previsão legal, pois no direito pátrio vem assegurado pelo direito de petição,

\footnotetext{
153 MEDAUAR, Odete. A Processualidade no Direito Administrativo. 2. ed. São Paulo: Revista dos Tribunais, 2008. p. 108.

154 DI PIETRO, Maria Sylvia Zanella. Direito Administrativo. 25. ed. São Paulo:Atlas, 2012. p. 686.

155 MEIRELLES, Hely Lopes. Direito Administrativo Brasileiro. 33. ed. São Paulo: RT, 2007. p. 690.

156 MEDAUAR, Odete. A Processualidade no Direito Administrativo. 2. ed. São Paulo: Revista dos Tribunais, 2008. p. 123-128; Direito Administrativo Moderno. 15. ed. São Paulo: RT, 2011. p. 180-182.
} 
previsto na alínea "a", do inciso XXXIV, artigo 5, da Constituição Federal de 1988); (c) a defesa técnica (polemizada por força da Súmula Vinculante $\mathrm{n}^{0} 5$ do STF); (d) o direito de ser notificado; e (e) o direito de solicitar a produção de provas, bem como da proibição de utilização de provas ilícitas, prevista no inciso LVI, do artigo $5^{\circ}$, da Constituição Federal de 1988.

O tema atinente à defesa técnica, aliás, encontra interessante elucidação na obra de Edmir Netto de Araújo ${ }^{157}$, que recomenda a harmonização da interpretação da Súmula Vinculante $n^{\circ} 05$, do Supremo Tribunal Federal, ponderando:

Relativamente recente (publicada no DJU de 16-5-2008), a Súmula Vinculante n. 5 do STF estabeleceu que "a falta de defesa técnica por advogado, no processo administrativo disciplinar, não ofende a Constituição". Não ofender a Constituição, entretanto, não significa que as leis (federal, estadual, distrital, municipal) sobre processo administrativo em geral ou disciplinar, em especial, não possam prever a obrigatoriedade de defesa técnica por advogado para indiciados, constituindo, portanto, caso de nulidade do feito, por ilegalidade, sua não observância, embora não inconstitucional, pois não ofende a Carta Magna, terá ofendido lei específica a respeito.

Lembra, nessa esteira, a solução dada pelo

Município de São Paulo (Lei no 8.989/79, art. 212 e parágrafo único) e pelo Estado de São Paulo (Lei $n^{\circ} 10.261 / 68$, com redação dada pela Lei Complementar n. 942/2003, art. 278, caput e $\S 1^{\circ}$, item 4; art. 282, caput e $\S 3^{\circ}$, art. 292, parágrafo único), na qual a interpretação da referida Súmula Vinculante tem sido nesse sentido, como aliás já havia sido sumulado (Súmula STJ n. 343) pelo Superior Tribunal de Justiça desde 21-9-2007.

Adverso à orientação traçada pela mencionada Súmula $\mathrm{n}^{\circ}$ 05, Nelson Nery Junior $^{158}$ a considera inconstitucional por entender que ofende, principalmente, o princípio da ampla defesa, e reclama:

A inexistência de defesa técnica no processo administrativo, notadamente no sancionador, que visa à imposição de penalidade, é fato de extrema gravidade, que compromete irremediavelmente a garantia constitucional da ampla defesa $\left(\mathrm{CF}, 5^{\circ}, \mathrm{LV}\right)$. Sem defesa por advogado, o servidor não poderá alegar matérias técnicas em seu benefício (v.g., prescrição, inépcia da portaria acusatória etc.), de modo que não terá exercido sua ampla defesa e a Constituição terá sido desrespeitada. A súmula vinculante STF - 05 é, portanto, inconstitucional.

\footnotetext{
157 ARAÚJO, Edmir Netto de. Curso de Direito Administrativo. 5. ed. São Paulo: Saraiva, 2010. p. 934.

158 NERY JUNIOR, Nelson. Princípios do processo na Constituição Federal. 9. ed. São Paulo: RT, 2009. p. 251.
} 
Dessas considerações emerge, dúvida não há, a qualidade de garantia fundamental que contempla a ampla defesa e o contraditório. Princípios, conduzidos ao pedestal de garantias fundamentais ${ }^{159}$, apresentam-se imprescindíveis no âmbito do processo administrativo para o próprio e regular cumprimento de suas finalidades e objetivos. Inafastáveis e impositivos para a validade do processo administrativo, inclusive o de natureza disciplinar, em um contexto sob a égide do modelo de Estado Democrático de Direito.

\subsubsection{Princípio da Duração Razoável do processo}

O princípio da duração razoável do processo foi inserido de forma expressa no texto da Constituição Federal por força da Emenda Constitucional n ${ }^{\circ} 45$, de 09 de dezembro de 2004, a denominada Reforma do Judiciário. O artigo 5º da Constituição Federal de 1988, foi alvo de acréscimo, incluindo-se o inciso LXXVIII, que assegura, no âmbito judicial e administrativo, um desenvolvimento temporal do processo, atendendo ao critério da razoabilidade, evitando manobras postergatórias e referindo-se aos meios que garantam a celeridade de sua tramitação.

Em sua essência, pondera Odete Medauar ${ }^{160}$, o princípio da razoável duração do processo administrativo visa a sua tramitação sem delongas desnecessárias, isto é, busca assegurar que o processo tramite sem extensos prazos de paralisação, para que a decisão seja tomada no menor prazo possível ou para que sejam cumpridos os prazos fixados em normas. Também ensina a autora que o princípio da duração razoável traz em seu escopo uma ideia de equilíbrio, de ponderação, de dosagem, de justo.

Celso Antônio Bandeira de Mello ${ }^{161}$ utiliza outra denominação, a de princípio da celeridade processual, e esclarece o conteúdo do referido standard:

[...] exige que a Administração atue expeditamente, pois deve proceder com presteza em todo o curso do processo, já que, de acordo com seu fundamento

\footnotetext{
159 Não se pretendeu, ao longo da explanação sobre os princípios da ampla defesa e do contraditório, adentrar na seara na natureza jurídica de ambos, apenas optou-se em qualificá-los como princípios, bem como, ao mesmo tempo, garantias, sem intenção de se aprofundar nesse recorte específico.

160 MEDAUAR, Odete. O princípio da razoável duração do processo. In: MEDAUAR, Odete; SCHIRATO, Vitor Rhein (Orgs.). Atuais rumos do processo administrativo. São Paulo: Revista dos Tribunais, 2010. p.100.

161 BANDEIRA DE MELlO, Celso Antônio. Curso de Direito Administrativo. 29. ed. São Paulo: Malheiros, 2012. p. 517.
} 
constitucional, residente no art. $5^{\circ}$, LXXVIII, haverá de ter duração 'razoável', de maneira a assegurar-se a 'celeridade de sua tramitação'.

O princípio da duração razoável do processo mantém interface com outros axiomas do direito ${ }^{162}$, quais sejam, a eficiência, a segurança jurídica e a legalidade. Ilustrativas dessa conexão, as decisões judiciais que trazem referências expressas a esses outros princípios em seus respectivos teores ${ }^{163}$. Em especial, com relação à eficiência, afirma Odete Medauar ${ }^{164}$ que o mesmo princípio traz a ideia de ação, agilidade para produção do resultado, de modo rápido e preciso, o que se contrapõe a descaso, negligência e omissão. Em tal sentido, o princípio da duração razoável do processo acrescenta a ideia de agilidade temporal.

Já no que tange à interface do axioma da duração razoável do processo com o da segurança jurídica ${ }^{165}$, é consenso que a demora de tomada de decisão, de forma injustificada, no bojo de um processo administrativo, a par de produzir, por si só, a própria negação do direito, afronta também o sistema pautado no modelo de Estado de Direito. O mesmo se repete com relação ao princípio da legalidade sob um víeis de cumprimento de formas previstas para o processo transcorrer, isto é, os prazos devem ser respeitados e quaisquer descumprimentos, ainda que justificados, geram a violação à razoabilidade da duração do processo.

É de se notar, também, que é função da Administração a busca da realização da Justiça $^{166}$, tornando efetivos os direitos consagrados pela Carta Magna de 1988. A demora na apreciação do direito já gera descumprimento à Constituição, infringe a paz social e leva ao descrédito da Administração, sobrecarregando o Poder Judiciário. Pelo valor Justiça, ainda se analisa a conciliação entre o contraditório e a ampla defesa de um lado e a celeridade

162 MEDAUAR, Odete. O princípio da razoável duração do processo. In: MEDAUAR, Odete; SCHIRATO, Vitor Rhein (Orgs.). Atuais rumos do processo administrativo. São Paulo: Revista dos Tribunais, 2010. p. 100-101.

163 STJ, Resp. 690811/RS, rel. Min. José Delgado, Dj 19.12,2005, p. 234; STJ, MS 12376/DF, rel. Min. Herman Benjamin, j. 28.03.2007, Dj. 01.09.2008; entre outros citados na obra (MEDAUAR, Odete. O princípio da razoável duração do processo. In: MEDAUAR, Odete; SCHIRATO, Vitor Rhein (Orgs.). Atuais rumos do processo administrativo. São Paulo: Revista dos Tribunais, 2010. p.104-107).

164 MEDAUAR, Odete. O princípio da razoável duração do processo. In: MEDAUAR, Odete; SCHIRATO, Vitor Rhein (Orgs.). Atuais rumos do processo administrativo. São Paulo: Revista dos Tribunais, 2010. p. 100-101.

165 MEDAUAR, Odete. O princípio da razoável duração do processo. In: MEDAUAR, Odete; SCHIRATO, Vitor Rhein (Orgs.). Atuais rumos do processo administrativo. São Paulo: Revista dos Tribunais, 2010. p. 100-101.

166 MEDAUAR, Odete. O princípio da razoável duração do processo. In: MEDAUAR, Odete; SCHIRATO, Vitor Rhein (Orgs.). Atuais rumos do processo administrativo. São Paulo: Revista dos Tribunais, 2010. p.101-102. 
processual de outro, invocando-se, para solução deste encontro de princípios, a proporcionalidade.

Odete Medauar ${ }^{167}$ realça os mecanismos de concretização deste princípio, invocando o preestabelecimento de prazo para decidir; a fixação de prazo para manifestação do particular ou para adotar providência a seu encargo; previsão de efeitos do silêncio ou descumprimento do prazo em relação ao interessado; controle interno do cumprimento dos prazos; responsabilização pelo descumprimento de prazos; perda, para a Administração, da possibilidade de atuar, após decurso de prazo não cumprido; redução do número de instâncias administrativas na tramitação e reunião conjunta de representantes de vários órgãos.

A esse passo, vale transcrever lição de Nery Junior ${ }^{168}$, quando afirma que ofende o princípio da razoável duração do processo administrativo o não reconhecimento de ofício, pela Administração, no âmbito de processo administrativo, de direitos já assegurados ao administrado, sejam esses decorrentes de nova legislação ou de decisões reiteradas da jurisprudência. E assim se manifesta:

No âmbito administrativo [...] É o poder público quem conduz o processo administrativo, instaurando-o, instruindo-o e julgando-o. Nada obstante existam os comandos constitucionais, e.g., da $\mathrm{CF} 5^{\circ}$ e 37 , o poder público não vem desempenhando a contento suas funções e amiúde deixa de respeitar e aplicar os princípios da legalidade, impessoalidade (imparcialidade), isonomia, devido processo legal, substancial (administrativo), eficiência, dos quais são corolários a boa-fé objetiva, a proibição de venire contra factum proprium e a confiança, que lhe impõem, por exemplo o reconhecimento ex officio da prescrição que aproveita ao administrado, o reconhecimento de ofício de consequências que a lei estabelece para o mau funcionamento da máquina administrativa [...] o reconhecimento ex officio de direito incontestável do administrado ou de vantagens do servidor já pacificadas na jurisprudência dos tribunais superiores, às vezes até sumuladas, entre outros casos.

\subsubsection{Princípio da Oficialidade}

A já mencionada Lei $n^{\circ} 9.784 / 99$, texto que disciplina o processo administrativo em esfera federal, insere, no seu bojo, dispositivos que concretizam o axioma da oficialidade, ex vi dos preceitos inscritos nos artigos $2^{\circ}$, inciso XII, $5^{\circ}$ e 29 . É de se ressaltar, porém, que

167 MEDAUAR, Odete. O princípio da razoável duração do processo. In: MEDAUAR, Odete; SCHIRATO, Vitor Rhein (Orgs.). Atuais rumos do processo administrativo. São Paulo: Revista dos Tribunais, 2010. p.102-103.

168 JUNIOR, Nelson Nery. Princípios do processo na Constituição Federal. 9. ed. São Paulo: RT, 2009. p. 319-320. 
aqui se trata de princípio confeccionado pela doutrina, reflexo da própria função administrativa, do cânone da legalidade, da finalidade pública a que se destina a atuação da Administração e, por evidente, da ideia prevalecente da supremacia do interesse público sobre o privado.

Sob a égide do princípio da oficialidade, cabe à Administração adotar as providências necessárias ao longo do processo, com vistas a alcançar o ato final. Isto respeitando-se, em qualquer hipótese, a legalidade, a ampla defesa, o contraditório e logicamente os demais princípios e garantias aplicáveis. Na realidade, a oficialidade se dirige ao Pode Público, impondo-lhe o dever de tomar providências e de cumprir a legislação sem a necessidade da provocação por parte do interessado ou de terceiro, ainda que possível a iniciação de um processo administrativo por estes.

Celso Antônio Bandeira de Mello ${ }^{169}$ afirma que

O fundamento do princípio da oficialidade também se radica na própria natureza constitucional das funções da Administração; isto é, deflui da missão própria do Poder Executivo no sistema de tripartição de Poderes, que a Lei Magna do país contempla no art. $2^{\circ}$. À Administração compete tomar a iniciativa - embora sempre fundada em lei - de buscar a realização do interesse público [...].

Enfrentando a questão, Hely Lopes Meirelles ${ }^{170}$ anota:

[...] o princípio da oficialidade ou da impulsão atribui sempre a movimentação do processo administrativo à Administração, ainda que instaurado por provocação do particular; uma vez iniciado, passa a pertencer ao Poder Público, a quem compete seu impulsionamento, até a decisão final. Se Administração o retarda, ou dele se desinteressa, infringe o princípio da oficialidade e seus agentes podem ser responsabilizados pela omissão. Outra consequência desse princípio é a de que [...] o processo (não) se extingue pelo decurso do tempo, senão quando a lei expressamente o estabelece.

A seu turno, Di Pietro ${ }^{171}$ defende a presença do princípio da oficialidade mesmo que não previsto em lei, considerando a vinculação da oficialidade administrativa ao princípio da finalidade pública, e adverte: "Essa executoriedade, sendo inerente à atuação administrativa, existe mesmo que não haja previsão legal; como a Administração Pública está obrigada a satisfazer ao interesse público, cumprindo a vontade da lei, ela não pode ficar dependente da iniciativa particular para atingir seus fins". Complementa a ideia, asseverando

169 BANDEIRA DE MELlo, Celso Antônio. Curso de Direito Administrativo. 29. ed. São Paulo: Malheiros, 2012. p. 517.

170 MEIRELLES, Hely Lopes. Direito Administrativo Brasileiro. 33. ed. São Paulo: RT, 2007. p. 688.

171 DI PIETRO, Maria Sylvia Zanella. Direito Administrativo. 25. ed. São Paulo: Atlas, 2012. p. 683. 


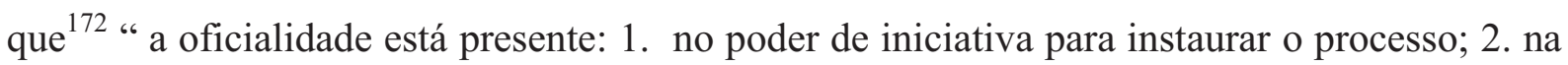
instrução do processo; 3. na revisão de suas decisões".

Há, no entanto, situações em que o princípio da oficialidade não encontra aplicação. Ocorrem quando a continuidade da tramitação do processo administrativo depende da manifestação de terceiro interessado e na ausência desta é inevitável para a Administração o arquivamento do respectivo expediente. É o caso em que o interesse individual tem conotação de exclusividade. Nessa hipótese, lembra Celso Antônio Bandeira de Mello ${ }^{173}$,

[...] é exatamente por isto que o princípio da oficialidade não vigora nos procedimentos ampliativos de direito suscitados pelo interessado, pois, em tais casos, o que está em pauta é um interesse seu buscado por iniciativa sua, e não um interesse da coletividade que a Administração estivesse a perseguir para implementar sua função própria.

Odete Medauar ${ }^{174}$ aponta como uma das decorrências desse princípio o fato de que a inércia dos sujeitos não acarreta a paralisação do procedimento, salvo o caso de providências pedidas pelo particular e que dependam de documentos que deva juntar; em tais casos, a Administração deverá conceder prazo para a juntada, encerrando o procedimento se tal não ocorrer.

\subsubsection{Princípio da Verdade Material}

Consiste a máxima no dever da Administração em buscar a verdade dos fatos, tendo por norte o interesse público, independentemente da iniciativa dos sujeitos do processo administrativo. Referido axioma relaciona-se de forma mais próxima com os princípios da ampla defesa, do contraditório, do devido processo legal, da supremacia do interesse público, e até mesmo com a oficialidade e formalismo moderado que guiam a tramitação do processo administrativo.

\footnotetext{
172 DI PIETRO, Maria Sylvia Zanella. Direito Administrativo. 25. ed. São Paulo:Atlas, 2012. p. 684.

173 BANDEIRA DE MELlo, Celso Antônio. Curso de Direito Administrativo. 29. ed. São Paulo: Malheiros, 2012. p. 517.

174 MEDAUAR, Odete. A Processualidade no Direito Administrativo. 2. ed. São Paulo: Revista dos Tribunais, 2008. p. 130-131.
} 
Ferraz e Dallari ${ }^{175}$ traçam uma linha de comparação deste cânone com o princípio da verdade formal, próprio dos processos judiciais, de preponderância no processo civil, e assinalam:

Em oposição ao princípio da verdade formal, inerente aos processos judiciais, no processo administrativo se impõe o princípio da verdade material. O significado deste princípio pode ser melhor compreendido por comparação: no processo judicial normalmente tem-se entendido que aquilo que não consta dos autos não pode ser considerado pelo juiz, cuja decisão fica adstrita às provas produzidas nos autos; no processo administrativo o julgador deve sempre buscar a verdade, ainda que, para isso, tenha que se valer de outros elementos além daqueles trazidos aos autos pelos interessados.

Essa comparação entre verdade material e verdade formal é objeto de análise, também, de Hely Lopes Meirelles ${ }^{176}$. O autor, aliás, denomina o princípio da verdade material de liberdade na prova e aduz que

Enquanto nos processos judiciais o juiz deve cingir-se às provas indicadas no devido tempo pelas partes, no processo administrativo a autoridade processante ou julgadora pode, até o julgamento final, conhecer de novas provas, ainda que produzidas em outro processo ou decorrentes de fatos supervenientes que comprovem as alegações em tela.

A busca pela verdade material no âmbito do processo administrativo tem como pressuposto a supremacia do interesse público e a finalidade pública, que dominam o panorama do Direito Administrativo, atribuindo à Administração, como dever, não se satisfazer com o que fora produzido pelos sujeitos do processo em termos de provas e sim realizar todos os atos necessários e legais para desvendar a verdade real, sob o pretexto do interesse público a que está adstrita.

É essa a definição que Celso Antônio Bandeira de Mello ${ }^{177}$ oferece: "Consiste em que a Administração, ao invés de ficar restrita ao que as partes demonstrem no procedimento, deve buscar aquilo que é realmente a verdade, com prescindência do que os interessados hajam alegado e provado, prescindência”. Citando Hector Escola, complementa Celso Antônio Bandeira de Mello ${ }^{178}$ alegando que é sob o pretexto do dever administrativo de

175 FERRAZ, Sérgio; DALLARI, Adilson Abreu. Processo Administrativo. São Paulo: Malheiros, 2001. p. 86.

176 MEIRELLES, Hely Lopes. Direito Administrativo Brasileiro. 33. ed. São Paulo: RT, 2007. p. 689.

177 BANDEIRA DE MELlo, Celso Antônio. Curso de Direito Administrativo. 29. ed. São Paulo: Malheiros, 2012. p. 512.

178 BANDEIRA DE MELlo, Celso Antônio. Curso de Direito Administrativo. 29. ed. São Paulo: Malheiros, 2012. p. 512. 
realizar o interesse público que se ancora o princípio da verdade material, ou seja, por conta do interesse público, a Administração deve sempre buscar a verdade substancial.

Sob o viés do dever de buscar a verdade real, Odete Medauar ${ }^{179}$ realiza uma ligação entre o princípio da verdade material - que também denomina de verdade real - com o princípio da oficialidade, asseverando que: “[...] exprime que a Administração deve tomar decisões com base nos fatos tais como se apresentam na realidade, não se satisfazendo com a versão oferecida pelos sujeitos".

Podemos vincular o princípio da verdade material com o axioma do formalismo moderado, a seguir delineado, considerando que a Administração deve preferir a busca pela verdade material, do que manter-se adstrita à verdade formal produzida pelos sujeitos do processo em prol do cumprimento de certas formalidades que, ao invés de alavancar a Administração em sua atuação perante um processo administrativo sob o ponto de vista da busca de informações necessárias para o deslinde dos autos, acaba por impedi-la em sua atuação mais investigativa.

Vale ressaltar os registros de Cintra, Grinover e Dinamarco ${ }^{180}$, atinentes à aplicação do princípio da verdade material e verdade formal no processo judicial, o qual denominam de princípio da livre investigação das provas. Fica evidenciado que "O princípio dispositivo consiste na regra de que o juiz depende, na instrução da causa, da iniciativa das partes quanto às provas e às alegações em que se fundamentará a decisão [...]”. Os autores ressaltam a característica mais importante ao magistrado, que é manutenção de sua imparcialidade.

Ocorre que, Cintra, Grinover e Dinamarco ${ }^{181}$ desenvolvem a teoria do princípio dispositivo sob uma perspectiva publicista do processo, considerando que não é mais possível entender o juiz como mero expectador da batalha judicial, ainda que no processo civil, pela preponderância dos direitos materiais em lide serem disponíveis, ao magistrado seja suficiente a apuração da verdade produzida pelas partes no processo, isto é, a verdade formal, sendo que, no processo penal, o inverso, uma vez estando sub judice direitos que encampem interesse público, prevaleceria, na apuração da verdade, o dever do magistrado em investigar de ofício

\footnotetext{
179 MEDAUAR, Odete. Direito Administrativo Moderno. 15. ed. São Paulo: RT, 2011. p. 183.

180 CINTRA, Antônio Carlos de Araújo; GRINOVER, Ada Pellegrini; DINAMARCO, Cândido R. Teoria Geral do Processo. 27. ed. São Paulo: Revista dos Tribunais, 2011. p. 70-72.

181 CINTRA, Antônio Carlos de Araújo; GRINOVER, Ada Pellegrini; DINAMARCO, Cândido R. Teoria Geral do Processo. 27. ed. São Paulo: Revista dos Tribunais, 2011. p. 70-72.
} 
outras evidências que entender necessárias para a solução da lide, ou seja, vigoraria o princípio da verdade material, assim como no processo administrativo.

Concluem, pois,

[...] que o processo civil, hoje, não é mais eminentemente dispositivo, como era outrora; e o processo penal, por sua vez, transformando-se de inquisitivo em acusatório, não deixou completamente à margem uma parcela de dispositividade das provas. Impera, portanto, tanto no campo processual penal como no campo processual civil, o princípio da livre investigação das provas, embora com doses maiores de dispositividade no processo civil. ${ }^{182}$

Destarte, essa noção de que no processo judicial vigora o princípio da verdade formal não traduz verdade absoluta. Pode-se, assim, ressaltar que, no processo administrativo, a busca pela verdade material deve ter limites, sobretudo considerando os princípios do contraditório, ampla defesa e devido processo legal. Não pode a Administração se utilizar de prova ilícita ou meios ilícitos na busca da verdade real, ou, até mesmo, violar axiomas basilares e fundamentais da pessoa, como o devido processo legal, por exemplo.

Ainda que prevaleça a ideia da verdade material no processo administrativo, a realidade identifica uma linha bastante tênue de distância entre verdade formal e verdade material, sendo que ambas se complementam como mecanismos de busca do real na tramitação do processo administrativo, com preponderância da verdade material, tendo em vista o interesse público, ainda que seja dever do julgador, quer em processo judicial, quer em administrativo, sempre procurar alcançar a verdade, independente do que os sujeitos ou partes produzirem a título de prova.

Nesse sentido, harmonizamo-nos com o entendimento de Fernão Borba Franco ${ }^{183}$, ou seja,

[...] o conteúdo do princípio da (mal) chamada verdade material é o de que no processo administrativo a cognição deve ser ampla, a fim de apurar a verdade relativa dos fatos com o maior grau de aproximação possível. É evidente, de outro lado, que o grau dessa cognição deve variar segundo o objeto do processo administrativo, como varia de acordo com o processo judicial, pois consistente numa técnica para efetividade do processo, variando segundo as exigências do direito e do objeto do processo, [...]".

182 CINTRA, Antônio Carlos de Araújo; GRINOVER, Ada Pellegrini; DINAMARCO, Cândido R. Teoria Geral do Processo. 27. ed. São Paulo: Revista dos Tribunais, 2011. p. 70-72. 


\subsubsection{Princípio do Informalismo ou Obediência às Formas e Procedimentos}

O princípio do informalismo, em sede de processo administrativo, não deve ser entendido como ausência de formalismo; na sua interpretação, há que se considerar uma atenuação dos efeitos de um formalismo inconveniente às finalidades do próprio processo. Daí não merecer destaque a expressão "informalismo", uma vez que pode levar a um entendimento diverso daquele que opera entre a aplicação da máxima que impõe obediência às formas e o processo administrativo.

Por isso o sistema concebido em torno das formas previstas na lei é assaz importante para a própria existência do processo. Este é marcado pela sucessão concatenada de atos administrativos com o objetivo de se atingir um provimento final, mediante a participação de sujeitos. E, neste particular, advertem Cintra, Grinover e Dinamarco ${ }^{184}$,

Dada essa unidade, o problema da forma pela qual deve ser celebrado cada ato processual passa a ser um problema das formas do próprio procedimento, o qual se desdobra em duas questões distintas: a) são necessárias as formas procedimentais? b) em caso de resposta afirmativa, qual a forma mais adequada para atingir o escopo do processo, em uma época determinada e segundo dadas condições?.

Hely Lopes Meirelles ${ }^{185}$ oferece outra visão a essas inquietações, atribuindo ao processo administrativo a aplicação do princípio do informalismo, segundo o qual esse “dispensa ritos sacramentais e formas rígidas [...], principalmente para os atos a cargo do particular. Bastam as formalidades estritamente necessárias à obtenção da certeza jurídica e à segurança procedimental".

De opinião similar, Celso Antônio Bandeira de Mello ${ }^{186}$ aduz que, pela aplicação do princípio do informalismo, no processo administrativo, “[...] significa que a Administração não poderá ater-se a rigorismos formais ao considerar as manifestações do administrado".

Ferraz e Dallari ${ }^{187}$, criticando a expressão, afirmam que

\footnotetext{
184 CINTRA, Antônio Carlos de Araújo; GRINOVER, Ada Pellegrini; DINAMARCO, Cândido R. Teoria Geral do Processo. 27. ed. São Paulo: Revista dos Tribunais, 2011. p. 349.

185 MEIRELLES, Hely Lopes. Direito Administrativo Brasileiro. 33. ed. São Paulo: RT, 2007. p. 689.

186 BANDEIRA DE MELlO, Celso Antônio. Curso de Direito Administrativo. 29. ed. São Paulo: Malheiros, 2012. p. 513.

187 FERRAZ, Sérgio; DALLARI, Adilson Abreu. Processo Administrativo. São Paulo: Malheiros, 2001. p. 80.
} 
O princípio da informalidade significa que devem ser observadas as formalidades estritamente necessárias à obtenção da certeza e da segurança jurídicas e ao atingimento dos fins almejados pelo sistema normativo. Devese dar maior prestígio ao espírito da lei do que à sua literalidade no tocante ao iter estabelecido pela norma jurídica disciplinadora do processo.

Deduz-se, pois, que é possível detectar mais um elemento importante, isto é, a ideia de que a flexibilização do formalismo só deve atingir o administrado ou só deve operar em favor do administrado, não podendo servir para a Administração se esquivar do cumprimento de suas obrigações reduzidas na observância das formas processuais, em quaisquer hipóteses.

Tecendo crítica à expressão "informalismo", tendo em vista os equívocos a que pode conduzir pela inexistência de formas e ritos, Odete Medauar ${ }^{188}$ o denomina de princípio do formalismo moderado. A autora ${ }^{189}$, ademais, o concebe

[...] em primeiro lugar, na previsão de ritos e formas simples, suficientes para propiciar um grau de certeza, segurança, respeito aos direitos dos sujeitos, o contraditório e a ampla defesa. Em segundo lugar, se traduz na exigência de interpretação flexível e razoável quanto às formas, para evitar que estas sejam vistas como fim em si mesmas, desligadas das verdadeiras finalidades do processo.

Mônica Martins Toscano Simões ${ }^{190}$, de sua parte, opta pela expressão formalismo moderado, pelas mesmas razões acolhidas por Odete Medauar, para qualificar a previsão das formas e ritos no processo administrativo e seu cumprimento pela Administração. Procedendo a uma linha divisória entre o papel do princípio do formalismo no processo judicial e no administrativo, ressalta que "[...] ao contrário do processo judicial, (o processo administrativo) não está, em regra circunscrito à rígida observância de formalidades. Nele prevalece o princípio do formalismo moderado, segundo o qual, no seu curso, as exigências formais devem ser atenuadas".

A expressão alcunhada por Di Pietro"191, ou seja, "Obediência à forma e aos procedimentos" torna-se bastante factível diante do alcance do princípio em destaque. De interesse, suas considerações sublinhando, "[...] $\mathrm{Na}$ realidade, o formalismo somente deve existir quando seja necessário para atender ao interesse público e proteger os direitos dos particulares".

\footnotetext{
188 MEDAUAR, Odete. Direito Administrativo Moderno. 15. ed. São Paulo: RT, 2011. p. 183.

189 MEDAUAR, Odete. Direito Administrativo Moderno. 15. ed. São Paulo: RT, 2011. p. 183.

190 SIMÕES, Mônica Martins Toscano. O Processo Administrativo e a Invalidação de Atos Viciados. São Paulo: Malheiros, 2004. p. 100.

191

DI PIETRO, Maria Silvia Zanella. Direito Administrativo. 25. ed. São Paulo: Atlas, 2011. p. 684.
} 
Em nosso ordenamento jurídico, os incisos VIII e IX, do artigo $2^{\circ}$, da conhecida Lei $\mathrm{n}^{\mathrm{o}} 9.784 / 99$, fixa a medida certa do grau de formalismo para o processo administrativo, em esfera federal, impondo a observância das formalidades essenciais à garantia dos direitos dos administrados e a adoção de formas simples, suficientes para propiciar adequado grau de certeza, segurança e respeito aos direitos dos administrados.

O exame das manifestações doutrinárias sobre o informalismo, no âmbito do processo administrativo, conduz ao entendimento de que a expressão que melhor alcança o seu conteúdo se resume à obediência às formas e ao procedimento. A sua aplicação deve ser mais rígida no processo judicial do que no administrativo. Mas a noção de informalismo não significa ausência de formalismo; retira-se, apenas, de sua órbita, a observância frenética às formas rígidas e essa atenuação ou flexibilidade do formalismo só deve ser operada em prol do administrado, na medida do interesse deste e da qualidade do interesse público objeto do processo administrativo. Este deve atender ao seu fim, garantir a segurança jurídica, a participação e a efetividade, e, para tanto, deve ser resguardado de modo a não se tornar um fim em si mesmo.

\subsection{O PROCESSO ADMINISTRATIVO SOB A GARANTIA DO DUE PROCESS OF LAW}

O dever de atuação da Administração por intermédio de processo que atenda ao ordenamento jurídico possui estreito vínculo com a cláusula do devido processo legal, preconizada expressamente pela Constituição Federal de 1988, no inciso LIV, do seu artigo $5^{\circ}$, in verbis: "Ninguém será privado da liberdade ou de seus bens sem o devido processo legal".

A relevância deste standard vem, há muito, reconhecida pela doutrina. Assim é que, referindo-se ao princípio como a uma real garantia constitucional, anota Ada Pelegrini Grinover ${ }^{192}$ o fato de que "O Estado de direito pode ter seu real coroamento através desses instrumentos processual-constitucionais de tutela dos direitos fundamentais do homem; é assim que o processo se transforma, de simples instrumento de justiça, em garantia de liberdade".

192 GRINOVER, Ada Pellegrini. As Garantias Constitucionais do Direito de Ação. São Paulo: RT, 1973. p. 19. 
Pois bem, em breve abordagem evolutiva, pode-se afirmar que a cláusula do devido processo legal teve origem no artigo 39, da Magna Carta de $1215^{193}$, a partir da expressão utilizada nesse documento - "law of the land". Não havia, contudo, originariamente alusão ao “due process of law”. O memorável documento proclamava em seu artigo 39: "No free man shall be taken, or imprisoned, or disseised, or outlawed, or exiled, or in any way destroyed, nor will we go upon him, nor will we send upon him, except by the legal judgement of his peers or by the law of the land ${ }^{194,, 195} 196$.

A expressão due process of law foi usada pela primeira vez por Eduardo III, em lei inglesa de $1354^{197}$, substituindo a ideia anterior de law of the land, prescrevendo-se: "None shall be condemned without trial. Also, that no Man, of what State or Condition that he be, shall be put out of the Land or Tenement, nor taken or imprisoned, nor disinherited, nor put to death, without being brought to Answer by Due process of law",198 199.

193 “Compelido por seus barões, João Sem Terra outorga, em 1215, a Magna Charta Libertatum, confirmada em 1297 por Eduardo I (Confirmatio Chartarum). Vista por muitos séculos como garantia solene de direitos individuais, a crítica moderna contribuiu para colocar em seu devido lugar o documento que apesar da forma de outorga de direitos, disfarçou, na realidade, um acordo de vontade entre o monarca e os súditos revoltados. Chegou-se a sugerir que a carta foi ditada exclusivamente para proteger os interesses da nobreza, mas na realidade ela constitui, com os demais pactos medievais, um antecedente das modernas Constituições, no que tange à forma escrita e à proteção de direitos individuais, ainda que de caráter imemorial e destinados a determinados homens. Pela primeira vez, a nobreza opõe ao monarca o princípio da supremacia de uma lei que se impõe ao próprio governante, antecipando a ideia fundamental do constitucionalismo do século XVIII" (GRINOVER, Ada Pellegrini. As Garantias Constitucionais do Direito de Ação. São Paulo: RT, 1973. p. 23-24).

194“ O exame minucioso do termo law of the land e o estudo dos antecedentes históricos da Magna Carta levaram a doutrina mais recente a interpretar a expressão como necessidade de observância das 'leis do país', para a validade do julgamento, contra o entendimento anterior de que o termo significaria um retorno às ordálias, em oposição à Justiça do soberano. Mas na frase by the legal judgement of his peers não se pode ainda ver, consoante a moderna doutrina, a primeira expressão do trial by jury. E quanto à expressão free man, que para a doutrina mais antiga abrangia todos os súditos, parece certo que se limitava à nobreza, cujos membros eram os únicos que, à época, gozavam daquela condição" (GRINOVER, Ada Pellegrini. As Garantias Constitucionais do Direito de Ação. São Paulo: RT, 1973. p. 24.

195 "O texto original previa 'Nullus liber homo capiatur vel imprisonetur aut disseisietur de libere tenemento suo vel libertatibus, vel liberis consuetatinibus suis, aut utilagetur, aut exuletur, aut aliquo modo destruatur, nec super eu ibimus, nec super eum mittemus, nisi per legale judicium parium suorum, vel per legem terrae'”, (GRINOVER, Ada Pellegrini. As Garantias Constitucionais do Direito de Ação. São Paulo: RT, 1973. p. 24, nota de rodapé $\mathrm{n}^{\mathrm{o}} 05$ ).

196 Tradução Livre: "Nenhum homem livre será preso, aprisionado ou privado de uma propriedade, ou tornado fora da lei, ou exilado, ou de maneira alguma destruído, nem agiremos contra ele ou mandaremos alguém contra ele, a não ser por julgamento legal dos seus pares, ou pela lei da terra"“".

197 A partir do documento jurado por Eduardo III, em 1354, no capítulo 39, no qual se insere pela primeira vez a expressão due process of law respeita a todos os súditos (GRINOVER, Ada Pellegrini. As Garantias Constitucionais do Direito de Ação. São Paulo: RT, 1973. p. 24. nota de rodapé nº 09).

198 GRINOVER, Ada Pellegrini. As Garantias Constitucionais do Direito de Ação. São Paulo: RT, 1973. p. 25.

199 Tradução Livre: "Ninguém poderá ser expulso das suas terras ou da sua morada, nem detido, preso, deserdado ou morto sem que lhe seja dada a possibilidade de se defender em um devido processo legal". 
Ainda no que tange à utilização de estreia do due process of law, registra-se que a já mencionada lei editada por Eduardo III utilizava pela primeira vez a língua inglesa na reedição da Carta, inicialmente escrita em latim, o que gerou certa obscuridade com relação à transição das expressões, sendo que estes termos, durante os séculos posteriores, mantiveramse como sinônimos, isto é, o due process of law manteve seu significado originário de garantia de julgamento genuíno, segundo a "lei da terra"200.

Posteriormente, ainda na Inglaterra, quase três séculos após a fixação de interpretação da cláusula do due process of law como direito a um oderly proceedings, por obra de Coke, o devido processo legal iniciava sua evolução para um sentido de garantia a um processo legal, um julgamento previsto já no seio da common law, sustentando-se a supremacia da Carta Magna em face dos poderes do soberano ${ }^{201}$.

Segundo relato de Ada Pellegrini Grinover, coube a Blackstone "[...] retomar a ligação entre o art. 39 da Magna Carta e a common law" ${ }^{202}$. Demais disso, lembra a autora que $^{203}$

[...] as revoltas da segunda metade do século XVII haviam ampliado as garantias da denominada law of the land, levando à formulação de documentos como o Habeas Corpus Act (1679), o Bill of Rigths dos Oranges (1689), o Act of Settlement (1701). - Assim é que, aduz a processualista - O art. 39 da Magna Carta, com as influências do pensamento do século XVII, transforma-se na garantia fundamental do processo inglês 204 .

A evolução da cláusula do devido processo legal na Inglaterra encontra-se vinculada, pois, ao conceito de law of the land, um direito restrito à nobreza inglesa do século XIII, em face do monarca, exigindo que fosse utilizada a lei da terra, de acordo com a praxe do local, mormente na área penal, visando à proteção aos direitos à vida, à liberdade e à propriedade da nobreza. Em momento posterior, já alçado à expressão due process of law, por Eduardo III, foi se modificando e passou a alojar em seu conceito uma abordagem de garantias processuais, com o enfoque na proteção dos direitos fundamentais aplicada a todos, e, obviamente, em face do governante.

\footnotetext{
200 MOREIRA, Egon Bockmann. Processo Administrativo. Princípios Constitucionais e a Lei 9784/99. 2. ed. São Paulo: Malheiros, 2003. p. 208. Ver também: GRINOVER, Ada Pellegrini. As Garantias Constitucionais do Direito de Ação. São Paulo: RT, 1973. p. 25.

201 Conforme GRINOVER, Ada Pellegrini. As Garantias Constitucionais do Direito de Ação. São Paulo: RT, 1973. p. 26.

${ }^{202}$ GRINOVER, Ada Pellegrini. As Garantias Constitucionais do Direito de Ação. São Paulo: RT, 1973. p. 26.

203 GRINOVER, Ada Pellegrini. As Garantias Constitucionais do Direito de Ação. São Paulo: RT, 1973. p. 26.

204 GRINOVER, Ada Pellegrini. As Garantias Constitucionais do Direito de Ação. São Paulo: RT, 1973. p. 26.
} 
Nos Estados Unidos ${ }^{205}$, houve a absorção do conceito inglês do law of the land por intermédio da colonização do século XVII. O instituto do devido processo legal migrou para as colônias britânicas e acabou sendo acolhido no sentido de garantia processual, manifestando-se, inicialmente, preponderantemente em seu aspecto processual.

A cláusula do devido processo legal fora, de forma pioneira, abarcada por algumas constituições das colônias da América do Norte, a exemplo das Constituições de Maryland, Pensilvânia e Massachusetts, antes de adentrar na Constituição dos Estados Unidos, por intermédio da Emenda Constitucional $\mathrm{V}^{206}$, que entrou em vigor em 1791, e, posteriormente, reforçada pela Emenda Constitucional $\mathrm{XIV}^{207}{ }^{208}$, que vigorou a partir de 1868.

Ada Pelegrini Grinover ${ }^{209}$ ressalta que

As colônias da América do Norte haviam tomado o conceito inglês de law of the land, no sentido que exsurgira das lições de Coke e Blackstone; e não diverso fora o entendimento de Madison, quando redigiu a V Emenda.

205 Nelson Nery Junior, citando Couture, afirma que "Antes mesmo da Constituição Federal americana, de 1787, algumas constituições estaduais daquele país já consagravam a garantia do due process of law, como por exemplo, as de Maryland ,Pensilvânia e Massachusetts, repetindo a regra da Magna Charta e da Lei de Eduardo III" (JUNIOR, Nelson Nery. Princípios do processo na Constituição Federal. 9. ed. São Paulo: RT, 2009. p. 78.

206 A Emenda Constitucional V, juntamente com as outras nove Emendas à Constituição representa o "Bill of Rights", todas aprovadas em 1791, pelo Parlamento Americano. "A Declaração de Independência dos Estados Unidos não se refere expressamente à cláusula. Inspirada por Jefferson, limitava-se a proclamar o princípio de que todos os homens são iguais por criação e dotados de direitos inalienáveis, como a vida, a liberdade e a busca da felicidade. A Convenção de Filadélfia, aprovando a Constituição dos Estados Unidos da América, não contempla a proteção de direitos individuais; tais garantias inscreveram-se como emendas à Constituição, aprovadas em 1791. Notadamente quanto à cláusula do due process of law, passou para o sistema constitucional como V Emenda, assim redigida: "No person shal be ... deprived of life, liberty or property without due process of law” (GRINOVER, Ada Pellegrini. As Garantias Constitucionais do Direito de Ação. São Paulo: RT, 1973. p. 27).

207 "Por proteger, o Bill of Rights, as liberdades individuais apenas contra lesões dos órgãos federais, sentiu-se mais tarde a necessidade de confiar aos mesmos órgãos federais a garantia dos indivíduos contra abusos praticados pelo poder estadual. Nova emenda, aprovada pelo Congresso e ratificada pelos Estados sob o n. XIV, incorporou-se, em 1868, à Constituição" (GRINOVER, Ada Pellegrini. As Garantias Constitucionais do Direito de Ação. São Paulo: RT, 1973. p. 28).

208 “A Décima Quarta Emenda, editada em 1868, estende aos estados federados a obrigação de se observar a cláusula do devido processo legal e cria um novo direito, o princípio da igualdade ("equal protection of the law”), nascido em razão das lutas raciais no âmbito da Guerra Civil americana. Uma série de casos decididos pela Suprema Corte levou ao entendimento de que não há qualquer diferença entre o Bill of Rights e a XIV Emenda, já que a emenda teria incorporado os aspectos mais importantes das dez primeiras emendas aplicandoos aos estados. Também ficou compreendido que a garantia do princípio da igualdade, tratado na XIV Emenda, deveria ser interpretado como um requisito para a realização do 'due process' previsto na V Emenda, válido para esfera federal” (BUENO, Vera Scarpinella. Devido Processo Legal e a Administração Pública no Direito Administrativo Norte-Americano. Uma breve comparação com o brasileiro. p. 18-19. In: FIGUEIREDO, Lucia Valle (Coord). Devido Processo Legal na Administração Pública. São Paulo: Max Limonad, 2001. p. 13 e seguintes). 
Mesmo com a promulgação da XIV ${ }^{\mathrm{a}}$ Emenda, o conteúdo da cláusula não sofreu modificação, referindo-se unicamente a garantias processuais.

Após uma primeira fase de interpretação do denominado conteúdo clássico do devido processo legal, como garantia processual, basicamente para o processo penal, referida cláusula incorporou, sobretudo através das decisões jurisprudenciais da Corte Suprema Norte Americana, um conteúdo substancial. Transformou-se, nas palavras de Ada Pelegrini Grinover $^{210}$ “[...] na garantia geral da ordem jurídica: judicial process não significa processo judicial, mas aplicação judicial da Lei e, por extensão, interpretação judicial da norma".

Nesse contexto, nos Estados Unidos, a expressão devido processo legal ecoava seus efeitos para além da submissão do Poder Público à Lei. Incidia sobre leis e atos administrativos considerados arbitrários e inconstitucionais, sendo que, nas palavras de Egon Bockmann Moreira $^{211}$,

A jurisprudência da Suprema Corte Estadunidense teve o mérito de dilatar essas fronteiras, através do controle substancial (de conteúdo, de fundo). A lei e o ato administrativo podem ser contrários ao devido processo legal não porque violam vida, liberdade ou propriedade através de visão autônoma e estrita do fenômeno processo. Mais do que isso, atos estatais podem produzir agressões de fundo ao devido processo legal quando seu conteúdo, sobre não guarnecer determinados interesses públicos, atinge direitos protegidos constitucionalmente. Trata-se do substantial due process of law - atualmente indissociável do benefício meramente processual.

Deve-se registrar que a Emenda $n^{\circ}$ XIV à Constituição Americana, pela cláusula do due process of law, possibilitou a extensão de sua proteção aos direitos à vida, à liberdade e à propriedade em face de atos e leis estatais, o que antes só era possível com relação ao governo federal. Nesse sentido, os direitos individuais previstos no "Bill of Rights" que, até então, eram opostos apenas contra os atos do governo federal, passaram a ser de observância obrigatória também para os governos estaduais.

Com efeito, observa Vera Scarpinella Bueno ${ }^{212}$ que

A Suprema Corte interpretou a cláusula do devido processo, prevista na $\mathrm{XIV}^{\mathrm{a}}$ Emenda, de forma ampla, isto é, elegeu-a como sendo a base constitucional para afirmar que toda a atividade dos estados-membros deveriam observar os direitos consagrados nas dez primeiras emendas à

\footnotetext{
210 GRINOVER, Ada Pellegrini. As Garantias Constitucionais do Direito de Ação. São Paulo: RT, 1973. p. 26.

211 MOREIRA, Egon Bockmann. Processo Administrativo. Princípios Constitucionais e a Lei 9784/99. 2. ed. São Paulo: Malheiros, 2003. p. 208.

212 BUENO, Vera Scarpinella. Devido Processo Legal e a Administração Pública no Direito Administrativo Norte-Americano. Uma breve comparação com o brasileiro. p. 23. In: FIGUEIREDO, Lucia Valle (Coord). Devido Processo Legal na Administração Pública. São Paulo: Max Limonad, 2001. p 13 e seguintes.
} 
Constituição (Bill of Rights). Poderia ter feito isso elegendo outro trecho da XIV Emenda, mas não o fez ${ }^{213}$.

Destarte, alinhando-se ao devido processo como garantia processual, emerge o devido processo substancial, assegurando o pleno exercício dos direitos individuais fundamentais, mormente considerando que, além das garantias processuais, incluindo aquelas que tutelam direitos individuais, a atuação do Estado, tanto da Administração (atos administrativos), quanto do Congresso (leis) deveria se afigurar razoável e não arbitrária, sob pena de estar infringindo o devido processo, como um todo.

Ressalta-se que a construção do conceito de devido processo substantivo viabilizava à Corte Suprema Americana adentrar no campo de apreciação da constitucionalidade de leis estaduais que regulavam aspectos econômicos e sociais da comunidade, com o escopo de verificar eventual lesão a direitos individuais de natureza econômica. No entanto, a partir no Neal Deal ${ }^{214}$, essa visão sofreu restrição com relação à interferência do judiciário na política governamental, no que tange aos ditos direitos individuais econômicos.

A crítica $^{215}$ irrogada ao fenômeno do devido processo legal substancial se deve à viabilização de profunda interferência da Suprema Corte Americana em questões políticas de fundo, obstruindo o desenvolvimento e evolução do direito privado e do direito social. E isto sem autorização expressa da Constituição que permitisse ao Judiciário, a uma, assumir a

213 "A Suprema Corte tinha dois caminhos lógicos para sustentar a autorização constitucional para ela controlar a constitucionalidade de atos dos Estados-membros, contrapondo-os aos direitos elencados no Bill of Rights. Ambos com base na XIV Emenda, ou ela se valia da frase 'no State shall make or enforceany law wich shall abrigdge the privileges or immunities of citizens of the United States' (os Estados não devem editar ou impor o cumprimento de qualquer lei que restrinja os privilégios ou imunidades dos cidadãos dos Estados Unidos), ou ela se valia de outra frase contida na XIV Emenda, segundo a qual os Estados não devem privar qualquer pessoa de sua vida, liberdade ou propriedade, sem o devido processo legal [...]. Sem nenhuma razão declarada, ela preferiu usar a segunda frase para sustentar o seu ponto de vista" (BUENO, Vera Scarpinella. Devido Processo Legal e a Administração Pública no Direito Administrativo Norte-Americano. Uma breve comparação com o brasileiro. p. 24. In: FIGUEIREDO, Lucia Valle (Coord). Devido Processo Legal na Administração Pública. São Paulo: Max Limonad, 2001. p 13 e seguintes).

214 Ada Pellegrini Grinover assim entende: "O fenômeno do substantive due process chegou à exasperação à época da legislação social do New Deal. Pertencem à época julgamentos extremos, como a avaliação do mérito de atos estatais determinando o preço das passagens em ferrovias particulares, ou as declarações de inconstitucionalidade de leis que limitavam as horas de trabalho, porquanto lesivas da autonomia contratual" GRINOVER, Ada Pellegrini. As Garantias Constitucionais do Direito de Ação. São Paulo: RT, 1973. p. 36.

215 Sob esse aspecto: PONTES DE MIRANDA. F. C. Os fundamentos Atuais do Direito Constitucional. Rio de Janeiro: Empresa de Publicações Técnicas, 1932. p. 115 e seguintes; FERREIRA FILHO, Manoel Gonçalves. Do processo Legislativo, São Paulo: Saraiva, 1968. p. 137; SAMPAIO DÓRIA, Antônio Roberto. Princípios Constitucionais Tributários e a Cláusula “Due Process of Law. São Paulo: RT, 1964. p. 49-50; BUENO, Vera Scarpinella. Devido Processo Legal e a Administração Pública no Direito Administrativo Norte-Americano. Uma breve comparação com o brasileiro. p. 27-33. In: FIGUEIREDO, Lucia Valle (Coord). Devido Processo Legal na Administração Pública. São Paulo: Max Limonad, 2001. p. 13 e seguintes. 
função legiferante de dizer quais são os direito individuais desenhados na Constituição, e, a outra, permitir ao judiciário analisar atos do governo e leis estaduais que confrontem os direitos individuais consagrados no Bill of Rights.

Vera Scarpinella Bueno ${ }^{216}$, referindo-se ao conceito atual do devido processo legal substancial, invoca dois grandes precedentes que refletem a atual postura da Suprema Corte Americana. Aponta o caso Bowers v. Hardwick ${ }^{217}$, julgado no ano de 1986, e o caso Washington x Glucksberg ${ }^{218}$, julgado em 1997. Nesta linha, remarca:

[...] a doutrina do devido processo legal substantivo pode ser traduzida como a possibilidade do judiciário interpretar a Constituição Federal americana e decidir quanto à constitucionalidade (razoabilidade) de um ato ou norma editada por um governo estadual ou local em razão de sua desconformidade com os direitos fundamentais consagrados nas dez primeiras emendas.

Ada Pelegrini Grinover anota a situação atual, resultado de um esforço interpretativo decorrente da denominada jurisprudência construtiva norte-americana, registrando que

Hoje, podemos afirmar que a cláusula é interpretada no sentido de eliminar qualquer obstáculo injustificado à tutela dos direitos individuais, substancial ou processual que seja. Desse modo, haverá violação da due process clause não somente onde forem desarrazoadas as formas técnicas de exercício dos poderes processuais, mas também onde a própria configuração do substantive rights possa prejudicar sua tutela, condicionando "irrazoavelmente" o resultado do processo ${ }^{219}$.

Em verdade, o due processo of law assumiu evidente relevância, notoriedade que transcende os panoramas britânico e norte-americano. Nesses territórios, remarca Egon Bockmann Moreira ${ }^{220}$, "Três motivos fundamentais podem ser apontados para explicar o

\footnotetext{
216 BUENO, Vera Scarpinella. Devido Processo Legal e a Administração Pública no Direito Administrativo Norte-Americano. Uma breve comparação com o brasileiro. p. 27-33. In: FIGUEIREDO, Lucia Valle (Coord). Devido Processo Legal na Administração Pública. São Paulo: Max Limonad, 2001. p. 13 e seguintes.

217 Vide: BUENO, Vera Scarpinella. Devido Processo Legal e a Administração Pública no Direito Administrativo Norte-Americano. Uma breve comparação com o brasileiro. p. 27-33. In: FIGUEIREDO, Lucia Valle (Coord). Devido Processo Legal na Administração Pública. São Paulo: Max Limonad, 2001. p. 13 e seguintes.

218 Vide: BUENO, Vera Scarpinella. Devido Processo Legal e a Administração Pública no Direito Administrativo Norte-Americano. Uma breve comparação com o brasileiro. p. 27-33. In: FIGUEIREDO, Lucia Valle (Coord). Devido Processo Legal na Administração Pública. São Paulo: Max Limonad, 2001. p. 13 e seguintes.

219 GRINOVER, Ada Pellegrini. As Garantias Constitucionais do Direito de Ação. São Paulo: RT, 1973. p. 38.

220 MOREIRA, Egon Bockmann. Processo Administrativo. Princípios Constitucionais e a Lei 9784/99. 2. ed. São Paulo: Malheiros, 2003. p. 201-204.
} 
valor que o due process of law assumiu na Inglaterra e nos Estados Unidos da América do Norte".

Com efeito, o primeiro dos aspectos a respaldar a importância histórica da cláusula do devido processo legal diz respeito à própria característica do Direito no sistema da common law, eminentemente jurisprudencial. Nesse contexto, o processo é alçado à ideia de Direito e, segundo Egon Bockmann Moreira ${ }^{221}$, "Nesse regime, em que o direito material era remetido e estava contido em regras e atos processuais, nada mais natural do que o surgimento da aguda preocupação com o "devido processo", como forma de proteção a direitos individuais".

Outra das razões a evidenciar a notoriedade do estudo da evolução histórica da cláusula do devido processo consiste no fato de que na Inglaterra não há Constituição escrita e, nessa perspectiva, surgiu no campo da common law inglês um direito formado por normas processuais destinadas a assegurar os direitos fundamentais. Egon Bockmann Moreira ${ }^{222}$ ressalta nesta linha que

[...] na justa medida em que a forma processual antecede os direitos materiais, assume especial relevância a garantia de que o "processo" seja realizado segundo o modo "devido". Dessa circunstância derivará a objetiva proteção a determinados direitos subjetivos, limitada ao conteúdo dos provimentos jurisdicionais. Provimentos que se tornarão vinculantes para os demais casos que os sucederem, consubstanciando uma positivação do entendimento fixado pelos tribunais ("precedentes"). O Direito é criado nas Cortes de Justiça".

Por fim, impõe-se a apresentação do caminho e cronologia percorridos pelo devido processo legal, considerando que no Continente Americano firmou-se a tradição do common law inglês por conta da colonização britânica respectiva, sendo que os contornos da cláusula foram evoluindo, em um primeiro momento, sendo aplicados em face do absolutismo real da Inglaterra, visando assegurar as liberdades públicas, e, posteriormente, desenvolvendose para uma noção também substancial, bem como aplicada em face de todos os Poderes do Estado. Nas palavras de Egon Bockmann Moreira ${ }^{223}$,

\footnotetext{
221 MOREIRA, Egon Bockmann. Processo Administrativo. Princípios Constitucionais e a Lei 9784/99. 2. ed. São Paulo: Malheiros, 2003. p. 202.

222 MOREIRA, Egon Bockmann. Processo Administrativo. Princípios Constitucionais e a Lei 9784/99. 2. ed. São Paulo: Malheiros, 2003. p. 203.

223 MOREIRA, Egon Bockmann. Processo Administrativo. Princípios Constitucionais e a Lei 9784/99. 2. ed. São Paulo: Malheiros, 2003. p. 204.
} 
Nesse aspecto o devido processo legal assume especial relevância. Ao distinguir a garantia da compreensão original inglesa, para ampliar sua proteção qualitativa (aspectos substancial e processual) e quantitativa (em face de todos os Poderes do Estado), a jurisprudência estadunidense conferiu-lhe o status de norma fundamental de todo o sistema. Hoje, nos Estados Unidos da América do Norte, o due process of law importa fundamento normativo de defesa dos mais relevantes direitos pessoais ainda que não venham previstos em qualquer texto legal.

Entre nós, a cláusula do devido processo legal, herdada do sistema da common law, se desenvolveu em parâmetros processuais e substanciais, sempre, porém, adequados à tradição brasileira do Direito.

Como foi observado, a emergência da cláusula do devido processo legal verificouse no âmbito do processo penal, enraizada no direito de defesa, passando a informar o processo civil em momento posterior, mas exclusivamente vinculada ao processo jurisdicional. Questão que se coloca é referente a sua aplicabilidade no âmbito do Direito Administrativo. A essa celeuma, o próprio artigo 5º da Constituição Federal de 1988, por força dos preceitos inscritos nos incisos LIV e LV, oferece elucidação. E deve ser registrado que tanto a doutrina de direito administrativo como a elaborada em sede processual ${ }^{224}$, posicionam-se favoravelmente a sua efetiva incidência na esfera do Direito Administrativo até mesmo antes do advento da Constituição de 1988. E mais, nesse diapasão direciona-se a jurisprudência do Supremo Tribunal Federal, haja vista a edição da Súmula 21225, datada de 1963.

Cabe, a esse passo, examinar em que medida a cláusula do devido processo legal deve ser aplicada no âmbito do processo administrativo, uma vez que o fenômeno processual, ligado à função administrativa, é manifestação do Estado Democrático de Direito. Sob esta perspectiva, que tem por foco a atuação administrativa, antes preponderantemente unilateral, impositiva e arbitrária, é reconhecida, hodiernamente, uma Administração que pauta suas

$224 \quad$ SANTIAGO DANTAS, F. C. de. Igualdade perante a lei e due process of law. Problemas de Direito Positivo. Rio nde Janeiro: Forense, 1986. p. 37 e seguintes; CINTRA, Antônio Carlos de Araújo; GRINOVER, Ada Pellegrini; DINAMARCO, Cândido R. Teoria Geral do Processo. 27. ed. São Paulo: Revista dos Tribunais, 2011. p. 89; MEDAUAR, Odete. A Processualidade no Direito Administrativo. 2. ed. São Paulo: Revista dos Tribunais, 2008. p. 83-87; FRANCO, Fernão Borba. Processo Administrativo. São Paulo: Atlas, 2008. p. 23-26; SIMÕES, Mônica Martins Toscano. O Processo Administrativo e a Invalidação de Atos Viciados. São Paulo: Malheiros, 2004. p. 63-67; FIGUEIREDO, Lucia Valle. Curso de Direito Administrativo. 8. ed. São Paulo: Malheiros, 2006. p. 443-456; MOREIRA, Egon Bockmann. Processo Administrativo. Princípios Constitucionais e a Lei 9784/99. 2. ed. São Paulo: Malheiros, 2003. p. 256-276.

225 STF Súmula no 21 - 13/12/1963 - Súmula da Jurisprudência Predominante do Supremo Tribunal Federal - Anexo ao Regimento Interno. Brasília: Imprensa Nacional, 1964, p. 39. Funcionário em Estágio Probatório Exoneração ou Demissão - Inquérito ou Formalidades Legais de Apuração de Capacidade - Funcionário em estágio probatório não pode ser exonerado nem demitido sem inquérito ou sem as formalidades legais de apuração de sua capacidade. Disponível em: <http://www.dji.com.br/normas_inferiores/ regimento_interno_e_súmula_stf/stf_0021.htm>. Acesso em: 28 out. 2012. 
ações pelos parâmetros restritivos da lei e mediante a participação do interessado através do princípio do contraditório.

Ressalta a evidência que o devido processo legal deve ser aplicado tanto em sua acepção procedimental, como em sua conotação substancial, garantindo-se um processo administrativo justo, cujos trâmites estejam previstos em legislação que atenda à razoabilidade, ou seja que respeite o Direito e assegure o pleno exercício dos direitos fundamentais da pessoa.

A esse respeito, aponta Celso Antônio Bandeira de Mello ${ }^{226}, 227$,

Estão aí consagrados, pois, a exigência de um processo formal e regular para que sejam atingidas a liberdade e a propriedade de quem quer que seja e a necessidade de que a Administração Pública, antes de tomar decisões gravosas a um dado sujeito, ofereça-lhe oportunidade de contraditório e de defesa ampla, no que se inclui o direito a recorrer das decisões tomadas. $\mathrm{Ou}$ seja: a Administração Pública não poderá proceder contra alguém passando diretamente à decisão que repute cabível, pois terá, desde logo, o dever jurídico de atender ao contido nos mencionados versículos constitucionais.

De sua parte, Carlos Roberto de Siqueira Castro ${ }^{228}$ bem observou a finalidade do conteúdo do devido processo legal, no âmbito da Administração Pública e do processo administrativo, sublinhando que "Do campo processual penal e civil a garantia do devido processo legal alastrou-se aos procedimentos travados pela Administração Pública, impondo, a esses, rigorosa observância dos princípios da legalidade e da moralidade administrativas".

Fernão Borba ${ }^{229}$, por sua vez, assinala as finalidades e o conteúdo do devido processo legal no âmbito do processo administrativo e registra:

O devido processo legal é cláusula ampla cuja finalidade é a de determinar a legalidade do processo, ou seja, sua obediência aos parâmetros constitucionais, e tem como seu conteúdo os princípios do contraditório, da igualdade das partes, da imparcialidade do julgador e seu convencimento racional. [...] De acordo com outra visão, o devido processo legal não

226 BANDEIRA DE MELlo, Celso Antônio. Curso de Direito Administrativo. 29. ed. São Paulo: Malheiros, 2012. p. 118.

227 E acrescenta Celso Antônio Bandeira de Mello, com relação ao devido processo legal aplicado no âmbito da Administração Pública e do processo administrativo: "Tal enquadramento da conduta estatal em pautas balizadoras, como se disse e é universalmente sabido, concerne tanto a aspectos materiais - pelo atrelamento do Estado a determinados fins antecipadamente propostos como validamente perseguíveis - quanto a aspectos formais, ou seja, relativos ao preestabelecimento dos meios eleitos como as vias idôneas a serem percorridas para que, através delas - e somente através delas - , possa o Poder Público exprimir suas decisões" (BANDEIRA DE MELlO, Celso Antônio. Curso de Direito Administrativo. 29. ed. São Paulo: Malheiros, 2012. p. 121).

228 CASTRO, Carlos Roberto de Siqueira. O Devido Processo Legal e a Razoabilidade das Leis na Nova Constituição do Brasil. Rio de Janeiro: Forense, 1989. p. 40.

229

FRANCO, Fernão Borba. Processo Administrativo. São Paulo: Atlas, 2008. p. 23. 
consiste apenas uma suma dos princípios aplicados ao processo, mas na garantia, inerente a todo processo, da observância dos valores liberdade, igualdade e participação, que lhe confere a característica [...] de microcosmo da democracia.

Merecem acolhida, outrossim, os apontamentos de Lucia Valle Figueiredo ${ }^{230}$ no que tange ao devido processo legal e ao aspecto substantivo que a cláusula ecoa. A autora remarca que "Os processualistas da atualidade entendem que está contido, no due process of law a lei - e assim poderá ser aplicada pelo magistrado - se não agredir, não entrar em confronto, não entrar em testilha, com a Constituição, com seus valores fundamentais”.

Lucia Valle Figueiredo ${ }^{231}$ prossegue para apontar como manifestação do devido processo legal, no âmbito do processo administrativo, os princípios do juiz natural ou do administrador competente; o amplo contraditório, condição essencial para decisão legal e justa; a igualdade entre as partes; a motivação das decisões; o direito à produção de provas lícitas; a verdade material ou princípio do inquisitório; o informalismo a favor do administrado; o direito à revisibilidade; o direito à defesa técnica; a sindicância; o direito ao silêncio; a proibição do reformatio in pejus e o direito dos interessados.

Importante observar que alguns princípios elencados pela autora como decorrentes do princípio do devido processo legal integram o rol de princípios aplicáveis ao processo administrativo em geral, supramencionados na presente dissertação. É que, na realidade, o devido processo legal é pressuposto dos demais princípios do processo administrativo, pois é com base nele que são edificados os preceitos aplicáveis e que darão o parâmetro legal ao bom andamento do processo administrativo, isto é, um processo administrativo que respeite os valores da justiça e da igualdade, bem como que siga as formas previamente delineadas pela norma, com estrito respeito e resguardo dos direitos fundamentais do indivíduo.

Ademais, não é somente em processos administrativos restritivos de direitos, a exemplo dos de caráter disciplinar, que deve se invocar a presença e a aplicação do devido processo legal, mormente sob o viés do contraditório e da ampla defesa. Mesmo em se tratando de processos administrativos sem contraditório, onde não há um conflito de interesses declarado - designados de ampliativos de direitos - deve-se seguir e respeitar o devido processo legal.

\footnotetext{
${ }^{230}$ FIGUEIREDO, Lucia Valle. Curso de Direito Administrativo. 8. ed. São Paulo: Malheiros, 2006. p. 443. 
Por fim, parece-nos precioso o conceito que Mônica Martins Toscano Simões ${ }^{232}$ oferece acerca da incidência do princípio do devido processo legal na instância administrativa. A autora realça a posição de garantia da cláusula, frisando:

[...] a garantia de que as decisões estatais - restringindo ou ampliando esferas jurídicas - serão alcançadas sempre com a observância do processo adequado. Para tanto, é mister zelar pela sequência de atos e fatos que devem preceder o ato administrativo final (aspecto formal), bem como considerar, no andamento do processo, as normas jurídicas pertinentes, de forma absolutamente harmoniosa com o interesse público (aspecto substancial).

Diante dessas ponderações se nos afigura inafastável do exame a que se pretende proceder a investigação quanto à origem, conteúdo e alcance do instituto do devido processo legal, em sede de processo administrativo. É que, a nosso ver, o tratamento das nulidades, no âmbito do processo administrativo, mantém estreita ligação com a cláusula do due process of law e, certamente, o ato atacado por vício no bojo de um processo administrativo assim o será por ter violado o devido processo legal, tanto em seu aspecto procedimental, como em seu aspecto substantivo, como será abordado em capítulo à parte.

\subsection{DA LEGISLAÇÃO DE REGÊNCIA DO PROCESSO ADMINISTRATIVO - AS TRÊS ESFERAS GOVERNAMENTAIS}

No Brasil, a doutrina direcionada à codificação do processo administrativo evoluiu pelo esforço dos teóricos dedicados ao estudo das questões administrativas, contemplada com o tratamento pioneiro de Themístocles Brandão Cavalcanti ${ }^{233}$ que, já em 1938, defendia a ideia da "[...] necessidade evidente de regular e codificar em um sistema harmônico e uniforme as normas processuais que interessam o andamento dos processos". Isso restava registrado no anteprojeto de Código de Processo Administrativo de sua autoria. Nessa esteira, afirmava o jurista: “[...] os interessados terão seus direitos assegurados, sabendo com antecedência qual o curso de suas demandas com a administração [...]; o principal é

\footnotetext{
232 SIMÕES, Mônica Martins Toscano. O Processo Administrativo e a Invalidação de Atos Viciados. São Paulo: Malheiros, 2004. p. 65.

233 BRANDÃO CAVALCANTI, Themístocles. A codificação do processo administrativo. Direito, Rio, v. I, n. 1, jan-fev. 1940. p. 99-112; BRANDÃO CAVALCANTI, Themístocles. Código do processo administrativo. In: Revista do Serviço Público, n. 3, 1938. p. 54-68; BRANDÃO CAVALCANTI, Themístocles. Tratado de Direito Administrativo. v. IV. 3. ed. Rio de Janeiro: Freitas Bastos, 1956. p. 537-538 apud MEDAUAR, Odete. A Processualidade no Direito Administrativo. 2. ed. São Paulo: Revista dos Tribunais, 2008. p. 195.
} 
proteger os direitos essenciais contra os excessos e isto parece ter sido atendido no anteprojeto".

No campo doutrinário, outros ilustres especialistas, a exemplo de Hely Lopes Meirelles e Manoel de Oliveira Franco Sobrinho, passaram a reclamar por uma codificação do processo administrativo e não há que se ignorar que, até mesmo antes da Carta Magna de 1988, leis esparsas e específicas continham regulamentação incidente sobre o instituto, sendo de se arrolar neste escaninho o estatuto dos servidores públicos que previa, inclusive, sanções e punição com base na verdade sabida, hoje tida como inconstitucional.

Após o advento da Constituição de 1988, foram editados textos de lei contendo previsões particulares sobre o processo administrativo, deparando-se o estudioso com preceitos de natureza processual na Lei de Licitações e no Código de Defesa do Consumidor $^{234}$. Relevante avanço, contudo, verificou-se com a convocação de comissão para a feitura de anteprojeto de lei disciplinadora do processo administrativo, em esfera federal, medida que culminou com a promulgação da Lei nº 9.784/99.

Cumpre evidenciar que o Brasil é constitucionalmente organizado nos moldes federativos, um Estado Federal que preordena a autonomia das entidades que o compõem. Assim, tanto em esfera federal, quanto na área de atuação dos Estados-membros, dos Municípios e do Distrito Federal, há competência para a definição de regras próprias a regulamentar o processo administrativo nos respectivos domínios. Neste trabalho serão objeto de análise o diploma federal, precursor, o texto legal a nortear a tramitação do processo administrativo do Estado de São Paulo e a lei editada no âmbito do Município de São Paulo.

\subsubsection{A elaboração do anteprojeto de lei do processo administrativo federal - O trabalho de criação da lei de regência}

A Comissão de Estudos, nomeada pelo Ministério da Justiça através de Portaria 1404, de 17 de outubro de 1995, contou com a participação de diversos juristas, destacandose, dentre eles, Caio Tácito, seu Coordenador, Maria Sylvia Zanella Di Pietro, Diogo de

\footnotetext{
234 Código de Defesa do Consumidor: Lei 8078, de 11 de setembro de 1990; Lei de Licitações Lei 8666, de 21 de junho de 1993.
} 
Figueiredo Moreira Neto, José Carlos Barbosa Moreira e Odete Medauar ${ }^{235}$, sendo esta designada por todos como a relatora dos trabalhos voltados a produzir lei que regulamentasse o processo administrativo.

Após diversas reuniões que ocorriam tanto em São Paulo e Rio de Janeiro, como também em Brasília, foi apresentado o Projeto de Lei no 2.464/1996 que, aprovado e sancionado, praticamente sem alterações, passou a constituir o primeiro documento legal a se debruçar sobre a regulação do processo administrativo.

Mantendo estreita simetria com os standards constitucionais, mormente com a aplicação dos brocardos do contraditório e da ampla defesa, o acesso à informação, a participação popular na tomada de decisões e a imposição de observância de regimes especiais, em detrimento da Lei Geral, que seria utilizada de forma subsidiária, a Lei federal $\mathrm{n}^{\mathrm{o}}$ 9.784/99 inaugurou a era do efetivo tratamento legal incidente sobre o processo administrativo, mantendo rigorosa observância quanto aos princípios estabelecidos no caput, do artigo 37, do Texto Fundamental que fixa o regime jurídico constitucional da atividade administrativa.

\subsubsection{A Lei federal $n^{0}$ 9.784, de 29 de janeiro de 1999 -}

\section{Lineamentos}

O texto em exame oferece, já no o seu Capítulo I, disposições gerais, advertindo o legislador que a norma aplica-se tanto em relação ao Poder Executivo Federal, como ainda aos órgãos dos Poderes Legislativo e Judiciário da União, no desempenho de função administrativa ${ }^{236}$. Desde logo, também, fixa os conceitos de “órgão", "entidade" e

235 A Comissão de Estudos referida acabou sendo ampliada por força da Portaria conjunta do Ministério da Justiça e o da Administração e Reforma do Estado - Portaria no 47, de 31.01.1996 - inserindo-se Adilson Dallari, José Joaquim Calmon de Passos, Paulo Eduardo Modesto e Carmen Lúcia Antunes Rocha. In MEDAUAR, Odete. A Processualidade no Direito Administrativo. 2. ed. São Paulo: Revista dos Tribunais, 2008. p. 199.

236 Importante citarmos a Súmula Vinculante 3, do STF, de 2007, editada na Sessão Plenária de 30/05/2007 - (DJe no 31/2007, p. 1, em 6/6/2007 - DJ de 6/6/2007, p. 1 - DO de 6/6/2007, p. 1) - "Processos Perante o Tribunal de Contas da União - Contraditório e Ampla Defesa - Anulação ou Revogação de Ato Administrativo Apreciação da Legalidade do Ato de Concessão Inicial de Aposentadoria, Reforma e Pensão - Nos processos perante o Tribunal de Contas da União asseguram-se o contraditório e a ampla defesa quando da decisão puder resultar anulação ou revogação de ato administrativo que beneficie o interessado, excetuada a apreciação da legalidade do ato de concessão inicial de aposentadoria, reforma e pensão". Disponível em: $<$ http://www.dji.com.br/normas inferiores/regimento interno_e súmula stf/0003vinculante.htm $>$. Acesso em: 28 out. 2012. 
"autoridade", indicando como e quando devem ser utilizados. Além disso, no seu artigo 2o, arrola os princípios ${ }^{237}$ de observância obrigatória pela Administração Pública e no parágrafo único deste mesmo preceito (artigo $2^{\circ}$ ) indica os critérios norteadores do processo administrativo $^{238}$.

No seu Capítulo II, o legislador passa a tratar dos direitos dos administrados perante a Administração, afigurando-se importante registrar o disposto no inciso IV, do artigo $3^{\circ}$, da aludida Lei $n^{\circ} 9.784 / 99^{239}$, que faculta a assistência de advogado à parte que esteja participando de um processo administrativo, salvo quando obrigatória a representação, por força de lei. Vale, nesta direção, lembrar a polêmica Súmula Vinculante $n^{\circ} 05$, editada pelo Supremo Tribunal Federal, a qual prevê que a falta de defesa técnica por advogado no processo disciplinar não ofende a Constituição. Merece apontar, de toda forma, que o texto em análise não preconiza a obrigatoriedade da presença de advogado em nenhum dos atos previstos. Depreende-se, pois, que a imposição quanto à presença de advogado para realizar a assistência ao sujeito submetido a um processo regulado pela Lei $n^{\circ}$ 9.784/99 só ocorrerá em caso de dispositivo inserido em outra legislação, nos moldes do inciso IV, do seu artigo $3^{\circ}$.

Os deveres dos administrados, de sua parte, não foram ignorados pelo legislador, sendo contemplados no Capítulo III do diploma. É neste segmento que vem disciplinado o início do processo administrativo.

A lei federal trata da matéria de forma detalhada e aborda este espinhoso tema de modo holístico. Assim, dedica o Capítulo V às partes e interessados; no Capítulo VI abriga as regras de competência, as hipóteses que autorizam a delegação e cuida, também, da avocação; o Capítulo VII fixa os impedimentos e cuida da suspeição de autoridade ou de servidor no que tangencia a atuação no âmbito do processo administrativo; o Capítulo VIII define a forma, trata do tempo e do lugar dos atos do processo administrativo ${ }^{240}$; o Capítulo IX disciplina a intimação dos atos; e o Capítulo $\mathrm{X}^{241}$ refere-se à instrução processual. ${ }^{242}$

237 “Art. 2ํㅡ A Administração Pública obedecerá, dentre outros, aos princípios da legalidade, finalidade, motivação, razoabilidade, proporcionalidade, moralidade, ampla defesa, contraditório, segurança jurídica, interesse público e eficiência". Disponível em: <http://www.planalto.gov.br/ccivil_03/leis/L9784.htm>. Acesso em: 28 out. 2012 .

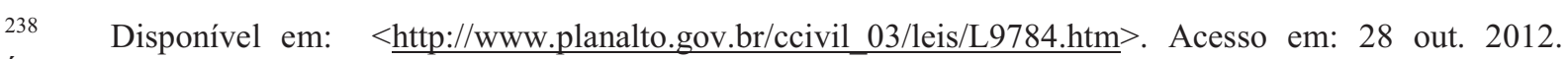
Íntegra da Lei 9784/99.

239 “Art. 3ํㅡ O administrado tem os seguintes direitos perante a Administração, sem prejuízo de outros que lhe sejam assegurados: [...] IV - fazer-se assistir, facultativamente, por advogado, salvo quando obrigatória a representação, por força de lei”. Disponível em: <http://www.planalto.gov.br/ccivil_03/leis/L9784.htm>. Acesso em: 28 out. 2012.

240 Nesse capítulo, a menção se faz proveitosa com referência à exigência do reconhecimento de firma somente quando houver dúvida de autenticidade, bem como à autenticação de documentos exigidos em cópia, 
O diploma vai além para, no Capítulo XI, estabelecer o dever de decidir; no Capítulo XII ${ }^{243}$, determinar a obrigatoriedade de motivação dos atos administrativos e apontar as hipóteses, exigindo nestes casos a indicação dos fatos e dos fundamentos jurídicos. $\mathrm{O}$ Capítulo XIII traz regras sobre a desistência, além de outros casos de extinção do processo administrativo; o Capítulo XIV ${ }^{244}$ disciplina a anulação, revogação e convalidação dos atos; e o Capítulo $\mathrm{XV}^{245}$, prevê as regras aplicáveis aos recursos administrativos.

que poderá ser feita pelo órgão administrativo, seguindo um entendimento de andamento do processo administrativo menos gravoso ao administrado. "Art. 22. Os atos do processo administrativo não dependem de forma determinada senão quando a lei expressamente a exigir. § $1 \underline{\mathrm{o}}$ Os atos do processo devem ser produzidos por escrito, em vernáculo, com a data e o local de sua realização e a assinatura da autoridade responsável. $\S 2 \underline{\underline{0}}$ Salvo imposição legal, o reconhecimento de firma somente será exigido quando houver dúvida de autenticidade. $\S 3 \underline{0}$ A autenticação de documentos exigidos em cópia poderá ser feita pelo órgão administrativo". Disponível em: $<$ http://www.planalto.gov.br/ccivil_03/leis/L9784.htm>. Acesso em: 28 out. 2012.

241 Sobre a instrução processual, ressaltam-se as seguintes previsões da Lei 9784/99, focadas sobre o princípio do contraditório e ampla defesa, quais sejam: “... Art. 30. São inadmissíveis no processo administrativo as provas obtidas por meios ilícitos. Art. 31. Quando a matéria do processo envolver assunto de interesse geral, o órgão competente poderá, mediante despacho motivado, abrir período de consulta pública para manifestação de terceiros, antes da decisão do pedido, se não houver prejuízo para a parte interessada. [...] Art. 32. Antes da tomada de decisão, a juízo da autoridade, diante da relevância da questão, poderá ser realizada audiência pública para debates sobre a matéria do processo. [...] Art. 37. Quando o interessado declarar que fatos e dados estão registrados em documentos existentes na própria Administração responsável pelo processo ou em outro órgão administrativo, o órgão competente para a instrução proverá, de ofício, à obtenção dos documentos ou das respectivas cópias. Art. 38. O interessado poderá, na fase instrutória e antes da tomada da decisão, juntar documentos e pareceres, requerer diligências e perícias, bem como aduzir alegações referentes à matéria objeto do processo. $\S 1$ o Os elementos probatórios deverão ser considerados na motivação do relatório e da decisão. [...] Art. 46. Os interessados têm direito à vista do processo e a obter certidões ou cópias reprográficas dos dados e documentos que o integram, ressalvados os dados e documentos de terceiros protegidos por sigilo ou pelo direito à privacidade, à honra e à imagem". Disponível em: <http://www.planalto.gov.br/ccivil_03/leis/L9784.htm> . Acesso em: 28 out. 2012.

242 Disponível em: <http://www.planalto.gov.br/ccivil 03/leis/L9784.htm>. Acesso em: 28 out. 2012. Íntegra da Lei 9784/99.

243 Também merecem menção as previsões sobre a motivação dos atos administrativos mediante a indicação dos fatos e dos fundamentos jurídicos, nos seguintes casos: "CAPÍTULO XII - DA MOTIVAÇÃO. Art. 50. Os atos administrativos deverão ser motivados, com indicação dos fatos e dos fundamentos jurídicos, quando: I neguem, limitem ou afetem direitos ou interesses; II - imponham ou agravem deveres, encargos ou sanções; III decidam processos administrativos de concurso ou seleção pública; IV - dispensem ou declarem a inexigibilidade de processo licitatório; V - decidam recursos administrativos; VI - decorram de reexame de ofício; VII - deixem de aplicar jurisprudência firmada sobre a questão ou discrepem de pareceres, laudos, propostas e relatórios oficiais; VIII - importem anulação, revogação, suspensão ou convalidação de ato administrativo. § 1ㅇ A motivação deve ser explícita, clara e congruente, podendo consistir em declaração de concordância com fundamentos de anteriores pareceres, informações, decisões ou propostas, que, neste caso, serão parte integrante do ato. $\S 2 \underline{\mathrm{O}} \mathrm{Na}$ solução de vários assuntos da mesma natureza, pode ser utilizado meio mecânico que reproduza os fundamentos das decisões, desde que não prejudique direito ou garantia dos interessados. § 3 o A motivação das decisões de órgãos colegiados e comissões ou de decisões orais constará da respectiva ata ou de termo escrito". Disponível em: <http://www.planalto.gov.br/ccivil_03/leis/L9784.htm>. Acesso em: 28 out. 2012.

244

Importante observarmos as previsões sobre a anulação, revogação e convalidação dos atos administrativos no decorrer do processo administrativo regulado pela Lei 9784/99. "CAPÍTULO XIV - DA ANULAÇÃO, REVOGAÇÃO E CONVALIDAÇÃO. Art. 53. A Administração deve anular seus próprios atos, quando eivados de vício de legalidade, e pode revogá-los por motivo de conveniência ou oportunidade, 
Nesse particular segmento recursal é que emerge o debate sobre a necessidade de caução para interposição de recurso administrativo, nos termos do $\S 2^{\circ}$, do artigo 56 , da mencionada Lei federal $n^{\circ} 9.784 / 99$. Este preconiza a necessidade de caução somente quando a lei o exigir. Mesmo assim, a ADI 1976/DF ${ }^{246}$, julgada em 28/03/2007, declarou

respeitados os direitos adquiridos. Art. 54. O direito da Administração de anular os atos administrativos de que decorram efeitos favoráveis para os destinatários decai em cinco anos, contados da data em que foram praticados, salvo comprovada má-fé. $\S 1$ No caso de efeitos patrimoniais contínuos, o prazo de decadência contar-se-á da percepção do primeiro pagamento. § 2 Considera-se exercício do direito de anular qualquer medida de autoridade administrativa que importe impugnação à validade do ato. Art. 55. Em decisão na qual se evidencie não acarretarem lesão ao interesse público nem prejuízo a terceiros, os atos que apresentarem defeitos sanáveis poderão ser convalidados pela própria Administração". Disponível em: <http://www.planalto.gov.br/ ccivil_03/leis/L9784.htm>. Acesso em: 28 out. 2012.

245 Os dispositivos citados na sequência tratam da regulação do recurso administrativo e da revisão, quais sejam: "CAPÍTULOXV - DO RECURSO ADMINISTRATIVO E DA REVISÃO. Art. 56. Das decisões administrativas cabe recurso, em face de razões de legalidade e de mérito. [...] $§ 2 \underline{0}$ Salvo exigência legal, a interposição de recurso administrativo independe de caução. $\S 3 \underline{0}$ Se o recorrente alegar que a decisão administrativa contraria enunciado da súmula vinculante, caberá à autoridade prolatora da decisão impugnada, se não a reconsiderar, explicitar, antes de encaminhar o recurso à autoridade superior, as razões da aplicabilidade ou inaplicabilidade da súmula, conforme o caso. (Incluído pela Lei $n^{\circ} 11.417$, de 2006). [...] Art. 59. Salvo disposição legal específica, é de dez dias o prazo para interposição de recurso administrativo, contado a partir da ciência ou divulgação oficial da decisão recorrida. § 1으 Quando a lei não fixar prazo diferente, o recurso administrativo deverá ser decidido no prazo máximo de trinta dias, a partir do recebimento dos autos pelo órgão competente. $\S 2 \underline{\mathrm{o}} \mathrm{O}$ prazo mencionado no parágrafo anterior poderá ser prorrogado por igual período, ante justificativa explícita. [...] Art. 61. Salvo disposição legal em contrário, o recurso não tem efeito suspensivo. Parágrafo único. Havendo justo receio de prejuízo de difícil ou incerta reparação decorrente da execução, a autoridade recorrida ou a imediatamente superior poderá, de ofício ou a pedido, dar efeito suspensivo ao recurso. Art. 62. Interposto o recurso, o órgão competente para dele conhecer deverá intimar os demais interessados para que, no prazo de cinco dias úteis, apresentem alegações. [...] Art. 64. O órgão competente para decidir o recurso poderá confirmar, modificar, anular ou revogar, total ou parcialmente, a decisão recorrida, se a matéria for de sua competência. Parágrafo único. Se da aplicação do disposto neste artigo puder decorrer gravame à situação do recorrente, este deverá ser cientificado para que formule suas alegações antes da decisão. Art. 64-A. Se o recorrente alegar violação de enunciado da súmula vinculante, o órgão competente para decidir o recurso explicitará as razões da aplicabilidade ou inaplicabilidade da súmula, conforme o caso. (Incluído pela Lei $\mathrm{n}^{\circ}$ 11.417, de 2006). Art. 64-B. Acolhida pelo Supremo Tribunal Federal a reclamação fundada em violação de enunciado da súmula vinculante, dar-se-á ciência à autoridade prolatora e ao órgão competente para o julgamento do recurso, que deverão adequar as futuras decisões administrativas em casos semelhantes, sob pena de responsabilização pessoal nas esferas cível, administrativa e penal. (Incluído pela Lei $\mathrm{n}^{\circ}$ 11.417, de 2006). Art. 65. Os processos administrativos de que resultem sanções poderão ser revistos, a qualquer tempo, a pedido ou de ofício, quando surgirem fatos novos ou circunstâncias relevantes suscetíveis de justificar a inadequação da sanção aplicada. Parágrafo único. Da revisão do processo não poderá resultar agravamento da sanção". Disponível em: <http://www.planalto.gov.br/ccivil_03/leis/L9784.htm>. Acesso em: 28 out. 2012.

246 “ADI 1976 / DF - DISTRITO FEDERAL - AÇÃO DIRETA DE INCONSTITUCIONALIDADE Relator(a): Min. JOAQUIM BARBOSA - Julgamento: 28/03/2007 Órgão Julgador: Tribunal Pleno Ementa: EMENTA: AÇÃO DIRETA DE INCONSTITUCIONALIDADE. ART. 32, QUE DEU NOVA REDAÇÃO AO ART. 33, § 2 $2^{\circ}$, DO DECRETO 70.235/72 E ART. 33, AMBOS DA MP 1.699-41/1998. DISPOSITIVO NÃO REEDITADO NAS EDIÇÕES SUBSEQUENTES DA MEDIDA PROVISÓRIA TAMPOUCO NA LEI DE CONVERSÃO. ADITAMENTO E CONVERSÃO DA MEDIDA PROVISÓRIA NA LEI 10.522/2002. ALTERAÇÃO SUBSTANCIAL DO CONTEÚDO DA NORMA IMPUGNADA. INOCORRÊNCIA. PRESSUPOSTOS DE RELEVÂNCIA E URGÊNCIA. DEPÓSITO DE TRINTA PORCENTO DO DÉBITO EM DISCUSSÃO OU ARROLAMENTO PRÉVIO DE BENS E DIREITOS COMO CONDIÇÃO PARA A INTERPOSIÇÃO DE RECURSO ADMINISTRATIVO. PEDIDO DEFERIDO. Perda de objeto da ação direta em relação ao art. 33, caput e parágrafos, da MP 1.699-41/1998, em razão de o dispositivo ter sido suprimido das versões ulteriores da medida provisória e da lei de conversão. A requerente promoveu o devido aditamento após a conversão da medida provisória impugnada em lei. Rejeitada a preliminar que sustentava a prejudicialidade da 
inconstitucional o preceito, impondo o depósito prévio ou o arrolamento prévio de bens ou direitos como condição para interpor recurso administrativo, por configurar, a par de lesão ao exercício do direito de petição, também ofensa aos princípios do contraditório e da ampla defesa, previstos, respectivamente, nos incisos XXXIV e LV, ambos do artigo $5^{\circ}$, da Constituição Federal de 1988.

Mais ainda, o Capítulo XVI dispõe sobre os prazos; o Capítulo XVII cuida das sanções; e o Capítulo XVIII ${ }^{247}$, o último, traz regra pertinente à aplicação subsidiária do diploma legal em destaque em relação à leis especiais ${ }^{248}$.

\subsubsection{O Tratamento legal do processo administrativo no Estado de São Paulo -}

\section{Lei estadual $n^{0} 10.177$, de 30 de dezembro de 1998}

O Estado de São Paulo, a seu turno, disciplinou o processo administrativo editando a Lei estadual $\mathrm{n}^{\circ} 10.177$, de 30 de dezembro de 1998, denominada de Lei Geral de Processo Administrativo do Estado de São Paulo. Esta, contudo, entrou em vigor somente 120 dias após sua publicação, isto é, em $1^{0}$ de maio de 1999, consagrando a primazia da União quanto ao tratamento do processo administrativo por via de lei.

O texto paulista é fruto, por sua vez, do esforço procedido por Comissão, constituída no início de 1990, sob a presidência de Carlos Ari Sundfield ${ }^{249}$ e sua proposta

ação direta em razão de, na lei de conversão, haver o depósito prévio sido substituído pelo arrolamento de bens e direitos como condição de admissibilidade do recurso administrativo. Decidiu-se que não houve, no caso, alteração substancial do conteúdo da norma, pois a nova exigência contida na lei de conversão, a exemplo do depósito, resulta em imobilização de bens. Superada a análise dos pressupostos de relevância e urgência da medida provisória com o advento da conversão desta em lei. A exigência de depósito ou arrolamento prévio de bens e direitos como condição de admissibilidade de recurso administrativo constitui obstáculo sério (e intransponível, para consideráveis parcelas da população) ao exercício do direito de petição (CF, art. $5^{\circ}$, XXXIV), além de caracterizar ofensa ao princípio do contraditório ( $\mathrm{CF}$, art. $\left.5^{\circ}, \mathrm{LV}\right)$. A exigência de depósito ou arrolamento prévio de bens e direitos pode converter-se, na prática, em determinadas situações, em supressão do direito de recorrer, constituindo-se, assim, em nítida violação ao princípio da proporcionalidade. Ação direta julgada procedente para declarar a inconstitucionalidade do art. 32 da MP 1699-41 - posteriormente convertida na lei 10.522/2002 -, que deu nova redação ao art. 33, § 2º do Decreto 70.235/72". Disponível em: $<$ http://www.stf.jus.br/portal/jurisprudencia $>$. Acesso em: 28 out. 2012.

247 Sobre a aplicação subsidiária da Lei 9.784/99 com relação aos processos administrativos específicos: “Art. 69. Os processos administrativos específicos continuarão a reger-se por lei própria, aplicando-se-lhes apenas subsidiariamente os preceitos desta Lei”. Disponível em: $<$ http://www.planalto.gov.br/ccivil_03/leis/L9784.htm>. Acesso em: 28 out. 2012.

248 Disponível em: <http://www.planalto.gov.br/ccivil 03/leis/L9784.htm>. Acesso em: 28 out. 2012. Íntegra da Lei 9784/99. 
encontrou por respaldado o artigo 113 da Constituição Paulista ${ }^{250}$, que remete à lei a fixação de prazos para prática de atos administrativos, bem como a disciplina de recursos. Edmir Netto de Araújo contribuiu para os estudos da proposta da Lei de Processo Administrativo no âmbito do Estado de São Paulo.

O projeto foi enviado ao Legislativo Estadual em 1998, onde tramitou sob a designação de Projeto ${ }^{\circ} 191$, de $1998^{251}$ e notam-se diversos pontos em comum no tocante ao tratamento da matéria, a exemplo do acolhimento da consulta pública e de audiência pública, entre outros.

De qualquer forma, constata-se que, embora o início de elaboração do texto estadual tenha tido precedência, foi o diploma federal a entrar em vigor e produzir efeitos de forma pioneira. É o que registra Odete Medauar ${ }^{252}$ :

Desse modo, embora a Lei estadual $\mathrm{n}^{\mathrm{o}} 10.177$ tenha o pioneirismo da existência, a Lei Federal 9784 tem o pioneirismo da eficácia, pois produziu efeitos desde $1^{\circ}$ de fevereiro de 1999. Além do mais, é possível que a publicação do projeto de lei de processo administrativo federal, seja na RDA, seja nas páginas oficiais do Legislativo Federal, tenha sido o incentivo, não só para a retomada da tramitação interna como para a célere tramitação externa do projeto estadual [...].

Na realidade, a Lei estadual $\mathrm{n}^{\mathrm{o}} 10.177 / 99$, por sua vez, disciplina o processo administrativo praticado no Estado de São Paulo e, do mesmo modo que a Lei Federal 9784/99, é de ser aplicada de forma subsidiária aos processos administrativos específicos ${ }^{253}$.

249 A doutrina Carlos Ari Sundfeld citada a seguir possui diversos artigos sobre a Lei 10.177/98: SUNDFELD, Carlos Ari; MUÑOZ, Guillermo Andrés (coord.). As Leis do Processo Administrativo. São Paulo: Malheiros, 2000.

250 Artigo 113, da Constituição Paulista: "Artigo 113 - A lei deverá fixar prazos para a prática dos atos administrativos e estabelecer recursos adequados a sua revisão, indicando seus efeitos e forma de processamento". Disponível em: <http:/www.legislacao.sp.gov.br/legislacao/index.htm>. Acesso em: 28 out. 2012.

251 “O confronto destas datas com as datas referentes à lei do processo administrativo estadual, mostra um antecedente mais remoto da lei paulista em comparação ao projeto federal; mas este foi enviado ao Legislativo Federal (em 22.10.1996) bem antes da remessa, ao Legislativo, do projeto estadual (16.4.1998). No Legislativo foi mais curta a tramitação do projeto estadual, daí a promulgação em 30.12.1998; e foi mais longa a tramitação do projeto federal, promulgado em 29.01.1999. Mas a Lei Federal 9784 entrou em vigor na data da sua publicação, ou seja, em $1^{\circ}$ de fevereiro de 1999, e a Lei Estadual 10177 só passou a produzir efeitos a partir de $1^{\circ}$ de maio de 1999". In: MEDAUAR, Odete. A Processualidade no Direito Administrativo. 2. ed. São Paulo: Revista dos Tribunais, 2008. p. 209.

252 MEDAUAR, Odete. A Processualidade no Direito Administrativo. 2. ed. São Paulo: Revista dos Tribunais, 2008. p. 209.

Sobre a aplicabilidade subsidiária da Lei 10.177/98, com relação aos processos administrativo que tenham disciplina legal específica: “TÍTULO I - Das Disposições Preliminares. Artigo $1^{\circ}$ - Esta lei regula os atos e procedimentos administrativos da Administração Pública centralizada e descentralizada do Estado de São Paulo, que não tenham disciplina legal específica. [...] Artigo $2^{\circ}$ - As normas desta lei aplicam - se subsidiariamente aos atos e procedimentos administrativos com disciplina legal específica". Disponível em: 
À semelhança do texto federal, a Lei Paulista contempla os princípios da Administração Pública, os atos administrativos, sua invalidação ${ }^{254}$, formalização, publicidade, prazo para a produção, as hipóteses de delegação de competências e de avocação, os princípios do procedimento administrativo. Evolui para tratar do direito de petição, da instrução do processo, dos prazos e dos recursos. E, ao disciplinar os procedimentos em espécie, dedica especial atenção à outorga, à invalidação, que mereceu detalhada regulamentação ${ }^{255}$, às medidas sancionatórias, à reparação de danos, à obtenção de certidões,

$<$ http://www.al.sp.gov.br/repositorio/legislacao/lei/1998/lei\%20n.10.177,\%20de\%2030.12.1998.htm>. Acesso em: 28 out. 2012.

254 Com relação ao sistema de vícios do ato administrativo previstos na Lei 10.177/98, merecem destaque os seguintes excertos: "CAPÍTULO II - Da Invalidade dos Atos - Artigo $8^{\circ}$ - São inválidos os atos administrativos que desatendam os pressupostos legais e regulamentares de sua edição, ou os princípios da Administração, especialmente nos casos de: I - incompetência da pessoa jurídica, órgão ou agente de que emane; II - omissão de formalidades ou procedimentos essenciais; III - impropriedade do objeto; IV - inexistência ou impropriedade do motivo de fato ou de direito; V - desvio de poder; VI - falta ou insuficiência de motivação. Parágrafo único - Nos atos discricionários, será razão de invalidade a falta de correlação lógica entre o motivo e o conteúdo do ato, tendo em vista sua finalidade. Artigo $9^{\circ}$ - A motivação indicará as razões que justifiquem a edição do ato, especialmente a regra de competência, os fundamentos de fato e de direito e a finalidade objetivada. Parágrafo único - A motivação do ato no procedimento administrativo poderá consistir na remissão a pareceres ou manifestações nele proferidos. Artigo 10 - A Administração anulará seus atos inválidos, de ofício ou por provocação de pessoa interessada, salvo quando: I - ultrapassado o prazo de 10 (dez) anos contado de sua produção; II - da irregularidade não resultar qualquer prejuízo; III - forem passíveis de convalidação. Artigo 11 A Administração poderá convalidar seus atos inválidos, quando a invalidade decorrer de vício de competência ou de ordem formal, desde que: I - na hipótese de vício de competência, a convalidação seja feita pela autoridade titulada para a prática do ato, e não se trate de competência indelegável; II - na hipótese de vício formal, este possa ser suprido de modo eficaz. $\S 1^{\circ}$ - Não será admitida a convalidação quando dela resultar prejuízo à Administração ou a terceiros ou quando se tratar de ato impugnado. $\S 2^{\circ}-$ A convalidação será sempre formalizada por ato motivado". Disponível em: <http://www.al.sp.gov.br/repositorio/legislacao/ lei/1998/lei\%20n.10.177,\%20de\%2030.12.1998.htm>. Acesso em: 28 out. 2012.

255 Importante registrarmos que a Lei 10177/98 prevê um procedimento específico para invalidação de atos administrativos e contratos administrativos, bem como no que couber outros ajustes: "Do Procedimento de Invalidação - Artigo 57 - Rege-se pelo disposto nesta Seção o procedimento para invalidação de ato ou contrato administrativo e, no que couber, de outros ajustes. Artigo 58 - O procedimento para invalidação provocada observará as seguintes regras: I - o requerimento será dirigido à autoridade que praticou o ato ou firmou o contrato, atendidos os requisitos do artigo 54; II - recebido o requerimento, será ele submetido ao órgão de consultoria jurídica para emissão de parecer, em 20 (vinte) dias; III - o órgão jurídico opinará sobre a procedência ou não do pedido, sugerindo, quando for o caso, providências para a instrução dos autos e esclarecendo se a eventual invalidação atingirá terceiros; IV - quando o parecer apontar a existência de terceiros interessados, a autoridade determinará sua intimação, para, em 15 (quinze) dias, manifestar-se a respeito; V concluída a instrução, serão intimadas as partes para, em 7 (sete) dias, apresentarem suas razões finais; VI - a autoridade, ouvindo o órgão jurídico, decidirá em 20 (vinte) dias, por despacho motivado, do qual serão intimadas as partes; VII - da decisão, caberá recurso hierárquico. Artigo 59 - O procedimento para invalidação de ofício observará as seguintes regras: I - quando se tratar da invalidade de ato ou contrato, a autoridade que o praticou, ou seu superior hierárquico, submeterá o assunto ao órgão de consultoria jurídica; II - o órgão jurídico opinará sobre a validade do ato ou contrato, sugerindo, quando for o caso, providências para instrução dos autos, e indicará a necessidade ou não da instauração de contraditório, hipótese em que serão aplicadas as disposições dos incisos IV a VII do artigo anterior. Artigo 60 - No curso de procedimento de invalidação, a autoridade poderá, de ofício ou em face de requerimento, suspender a execução do ato ou contrato, para evitar prejuízos de reparação onerosa ou impossível. Artigo 61 - Invalidado o ato ou contrato, a Administração tomará as providências necessárias para desfazer os efeitos produzidos, salvo quanto a terceiros de boa fé, determinando a apuração de eventuais responsabilidades". Disponível em: $<$ http://www.al.sp.gov.br/repositorio/legislacao/lei/ 1998/lei\%20n.10.177,\%20de\%2030.12.1998.htm>. Acesso em: 28 out. 2012. 
ao acesso a informações pessoais e a possibilidade de sua retificação e, por último, ao caso de denúncia.

\subsubsection{O Tratamento legal do processo administrativo no Município de São Paulo -}

\section{Lei municipal no 14.141, de 27 de março de 2006}

No Município de São Paulo, a Lei Geral do Processo Administrativo ${ }^{256}$ é documento editado já no século XXI; seguindo o sistema adotado em campo federal e estadual, porém, a seu turno se aplica subsidiariamente aos processos administrativos que possuem regulamentação específica ${ }^{257}$.

A Lei Municipal no 14.141/2006 assemelha-se muito à Lei Federal nº 9.784/99, e, certamente, é positiva essa aproximação entre os teores da legislação federal e municipal, assim como, em certa medida, da legislação estadual citada acima, uma vez que, no abrigo de um Estado Federal, como é o Brasil, a harmonização legislativa atinente ao processo administrativo denota um caminhar para a unificação de princípios e regras que possam conduzir a atuação uniforme da Administração Pública através do processo administrativo.

Essa é a lição de Odete Medauar ${ }^{258}$ : “A similaridade dos textos de leis de processo administrativo, num Estado Federal, revela-se muito positiva, sobretudo porque facilita a atuação dos interessados nos diversos entes federativos e porque evidencia um padrão comum da legislação brasileira, como um todo, nesta matéria".

Como tópicos de destaque do documento municipal há de se evidenciar os dispositivos que cuidam dos direitos dos munícipes, de seus deveres, do momento de inicialização do processo administrativo. Trata, ainda, da distinção entre processos comuns e

\footnotetext{
256 É possível ter acesso à íntegra da Lei 14.141/2006 no site da Prefeitura do Município de São Paulo: $<$ http://www.prefeitura.sp.gov.br/cidade/secretarias/planejamento/processos/legislacao/index.php?p=26267>.

257 Previsão de aplicação subsidiária da Lei 14141/2006 aos processos administrativos municipais com regulamentação específica: "Art. $1^{\circ}$ Esta lei estabelece normas comuns aplicáveis aos processos administrativos no âmbito da Administração Municipal. [...] Art. $8^{\circ}$ Distinguem-se os processos em: I - processos comuns; II processos especiais. Art. $9^{\circ}$ Os processos especiais são aqueles disciplinados por normas próprias distintas das aplicáveis nos processos comuns, aplicando-se-lhes subsidiariamente os demais preceitos desta lei. Parágrafo único. Enquadram-se, dentre outros, na categoria de especiais, os processos referentes às seguintes matérias: I licenciamento ambiental, edilício, sanitário e urbanístico; II - licitação; III - disciplinar; IV - administrativotributário; V - tomada de contas; VI - tombamento". Disponível em: <http://www.prefeitura.sp.gov.br/ cidade/secretarias/planejamento/processos/legislacao/index.php?p=26267>. Acesso em: 28 out. 2012.
}

258 MEDAUAR, Odete. A Processualidade no Direito Administrativo. 2. ed. São Paulo: Revista dos Tribunais, 2008. p. 210. 
especiais, fixando preceitos gerais em relação ao primeiro, dos interessados, da competência, dos impedimentos e da suspeição. Indica a forma, o tempo e a comunicação dos atos do processo, dispõe sobre a instrução, a produção das decisões e da aplicação de sanções. Cuida dos recursos e disciplina o pedido de vista e a tramitação dos requerimentos de cópias e certidões.

\subsection{DO PROCESSO ADMINISTRATIVO DISCIPLINAR - TRATAMENTO LEGAL DIFERENCIADO}

\subsubsection{Regime jurídico-legal no âmbito da União, do Estado de São Paulo e do Município de São Paulo}

De significativa relevância para a pesquisa pretendida neste trabalho apresenta-se o estudo, ainda que perfunctório, do regime disciplinar dos servidores públicos civis e, em especial, o sistema de apuração do ilícito administrativo por intermédio do processo que tramita no âmbito da Administração. Isto até porque doutrina e jurisprudência, em consenso, apontam a sede do processo administrativo disciplinar como um dos focos principais de ocorrência das ilegalidades no Direito Administrativo.

Oportuno o magistério de Edmir Netto de Araújo ${ }^{259}$ acerca do ilícito administrativo que o define como a

[...] ação ou omissão antijurídica, culpável, prejudicial, especialmente catalogada nos estatutos funcionais e outras normas que disciplinam a atividade dos agentes públicos. [e complementa] Essa ação ou omissão pode relacionar-se com a hierarquia, ou com as próprias condições de funcionamento dos órgãos estatais, ou ainda com a própria condição funcional do agente público, atingindo em alguns casos tal gravidade que será objeto de tipificação penal, independente de seu enquadramento administrativo.

A análise do ilícito administrativo e suas espécies deve ser apreciada respeitandose a ampla defesa, o contraditório e o devido processo legal, preceitos que devem servir de superfície à atuação da Administração Pública; isto resta evidenciado em sede de processo

259 ARAÚJO, Edmir Netto de. Curso de Direito Administrativo. 5. ed. São Paulo: Saraiva, 2010. p. 915. 
administrativo disciplinar que, em geral, marcha para uma decisão administrativa sancionatória, capaz de restringir direitos do servidor público e conduzindo, não raras vezes, à judicialização da questão, mormente no que tange aos critérios da legalidade do processo administrativo.

Acompanhando, ainda, o entendimento perfilhado por Edmir Netto de Araújo ${ }^{260}$, cabe apontar a sua visão da ocorrência do ilícito administrativo, indigitando quatro hipóteses, quais sejam:

a) ilícito administrativo puro disciplinar, quando atenta contra os princípios da hierarquia e subordinação, sem, entretanto, caracterizar qualquer infração penal (insubordinação, p. ex.); b) ilícito administrativo puro funcional (ou não disciplinar), que fere a boa ordem do serviço público, não envolvendo matéria referente à hierárquica ou relação de subordinação (participar de gerência $[\ldots]$ comércio na repartição $[. .$.$] etc.); c) ilícito administrativo$ criminal disciplinar, que envolve comportamento relacionado à hierarquia, mas também tipificado na lei penal (desobediência; ofensas físicas contra superior, em serviço etc.); d) ilícito administrativo criminal funcional (ou não disciplinar), que, tipificado como crime, não constitui, todavia, infração que atenta contra a hierarquia (p. ex., abandono de cargo, advocacia administrativa etc.).A esses núcleos, o mestre se reporta como "[...] aspecto substantivo do ilícito administrativo,"261.

Resta examinar o teor da legislação incidente sobre o assunto, examinando as normas que regulam o modo pelo qual a Administração Pública irá apreciar e julgar os ilícitos administrativos verificados. E isto no âmbito das três esferas governamentais acima apontadas. Excetua-se dessa análise o bloco dos servidores sob o regime celetista ${ }^{262}$ e os militares $^{263}$, passando a ser objeto do estudo o aspecto adjetivo do ilícito administrativo

\footnotetext{
260 ARAÚJO, Edmir Netto de. O ilícito administrativo e seu processo. São Paulo: RT, 1994. p. 135-136.

261 ARAÚJO, Edmir Netto de. O ilícito administrativo e seu processo. São Paulo: RT, 1994. p. 136.

262 Para não nos aprofundarmos em tema paralelo ao foco central da presente dissertação, não analisaremos os aspectos substantivos e adjetivos do ilícito administrativo daqueles servidores vinculados ao regime celetista. Vide Consolidação das Leis do Trabalho - Decreto-Lei $\mathrm{n}^{0}$ 5.452, de 01 de maio de 1943. Disponível em: $<$ http://www.planalto.gov.br/ccivil_03/decreto-lei/del5452.htm>. Acesso em: 28 out. 2012.

263 Também não abordaremos o tratamento do regime disciplinar referente aos militares, tanto no âmbito federal, quanto estadual. Vide Estatuto dos Militares e Decreto que regulamenta o referido Estatuto em âmbito federal - Lei $\mathrm{n}^{\circ}$ 6.880, de 09 de dezembro de 1980 e Decreto ${ }^{\circ}$ 4.307, de 18 de julho de 2002. Disponível em: $<$ http://www.planalto.gov.br/ccivil 03/decreto/2002/D4307.htm $>$. Acesso em: 28 out. 2012. No âmbito do Estado de São Paulo, a Lei que trata sobre o regime disciplinar dos policiais militares é a Lei Complementar $n^{\circ}$ 893, de 09 de março de 2001 - Disponível em: <http://www.al.sp.gov.br/repositorio/legislacao/ lei\%20complementar/2001/lei\%20complementar \%20n.893,\%20de\%2009.03.2001.htm>. Acesso em: 28 out. 2012 - e regulamentos específicos editados pelo Executivo Estadual.
} 
praticado pelos servidores estatutários civis ${ }^{264}$, isto é, o seu processo administrativo de perfil disciplinar ${ }^{265}$.

A notoriedade da matéria disciplinar e do respectivo processo é indicadora da variedade e quantidade de leis que tratam deste espinhoso assunto. Direitos e deveres, as sanções, a tipificação do ilícito e, principalmente, o processo administrativo para a sua apuração vêm sendo tema presente na legislação em vigor. Neste segmento, serão examinadas: (1) no âmbito da União, a Lei no 8.112, de 11 de dezembro de $1990^{266}$; (2) no âmbito do Estado de São Paulo, a Lei n ${ }^{\circ} 10.261$, de 28 de outubro de $1968^{267}$, texto que sofreu alteração por intermédio da edição da Lei Complementar no 942 , de 06 de junho de 2003, dentre outras atualizações; (3) no âmbito do Município de São Paulo, a Lei 8.989, de 29 de outubro de $1979^{268}$, com as reformas advindas da Lei 13.519, de 06 de fevereiro de 2003, e de outros documentos legais de atualização.

Cumpre observar que, nas legislações acima citadas, diversas as disposições que se assemelham do ponto de vista da estrutura da norma. No entanto, podem ser identificadas diferenças no tratamento da matéria, atendendo às peculiaridades de cada regime disciplinar. Aqui a abordagem terá por foco aspectos presentes em todas as legislações, que digam respeito à realização do processo administrativo disciplinar, alçando elementos que irão nos servir na análise de seus vícios e das causas de sua ocorrência.

Nesta trilha, um dos aspectos que se nos afigura pertinente consiste no exame do processo administrativo disciplinar na sua modalidade de Meios Sumários e a Sindicância. Trata-se de processo administrativo usualmente vinculado à aplicação do instituto da Verdade Sabida no Direito Administrativo, visão até mesmo anterior à Constituição Federal de 1988. Sua finalidade consiste em apreciar ilícitos administrativos de natureza leve, em relação aos 264 Outrossim, não abordaremos a Lei Orgânica da Polícia do Estado de São Paulo - Lei Complementar $\mathrm{n}^{\circ}$
207, de 05 de janeiro de 1979. Disponível em: <http://www.al.sp.gov.br/repositorio/legislacao/
lei\%20complementar/1979/lei\%20complementar\%20n.207,\%20de\%2005.01.1979.htm>. Acesso em: 28 out.
2012.

265 Complementa Edmir Netto de Araújo: "No entanto, a autoridade que tiver ciência de irregularidade no desenvolver dos serviços públicos é obrigada a promover sua apuração, objetivando a caracterização da existência e autoria do ilícito administrativo porventura ocorrido e também a atribuição da responsabilidade administrativa ao servidor faltoso. Essa questão nos leva então ao estudo do aspecto adjetivo do ilícito, que abrange em especial os meios legais que o Direito coloca à disposição da autoridade pública para promover essa apuração. [...]” (ARAÚJO, Edmir Netto de. Curso de Direito Administrativo. 5. ed. São Paulo: Saraiva, 2010. p. 914).

266 Disponível em: <http://www.planalto.gov.br/ccivil_03/leis/L8112cons.htm>. Acesso em: 28 out. 2012.

267 Disponível em: $\quad<$ http://www.al.sp.gov.br/repositorio/legislacao/lei/1968/lei\%20n.10.261,\%20de\% 2028.10.1968.htm>. Acesso em: 28 out. 2012. 
quais o conhecimento direto e imediato pela autoridade superior é suficiente para a aplicação da penalidade e a consequente responsabilização do servidor.

Após a promulgação do Texto Fundamental de 1988, que constitucionalizou os princípios norteadores da Administração Pública, dentre os quais, o contraditório, a ampla defesa e o devido processo legal, a aplicação de penalidade pela verdade sabida resta absolutamente inconstitucional, não podendo, em nenhuma hipótese prevalecer. É o magistério de Edmir Netto de Araújo, sublinhando que “[...] tratando-se de aplicação de penalidades disciplinares, a regra é que a responsabilidade do servidor seja indubitavelmente apurada, assegurando-se a bilateralidade de audiência, o contraditório e a ampla defesa do indiciado" 269 .

A Lei Federal $n^{\circ} 8.112 / 90$ não dispõe sobre o instituto da verdade sabida, diferentemente dos Estatutos vigentes em esfera estadual (Estado de São Paulo) e no Município de São Paulo, que adotaram a possibilidade de aplicação da pena mediante a verdade sabida para casos de repreensão e suspensão. No caso do Estado de São Paulo, a Lei $\mathrm{n}^{\mathrm{o}} 10.261 / 68$, na sua origem, previa o instituto da Verdade Sabida, previsto nos seus artigos 253 e $254^{270}$. Contudo, após atualização introduzida pela Lei Complementar no 942/2003, não mais é possível qualquer aplicação de penalidade sem a abertura para defesa e contraditório. Vale lembrar que a Lei $n^{\circ} 10.177 / 98$, que disciplina o processo administrativo genérico, no Estado de São Paulo, e encontra aplicação subsidiária nos casos dos processos administrativos disciplinares, derrogou qualquer possibilidade de aplicação de pena sem o devido processo legal, a ampla defesa e o contraditório, nas hipóteses de processos de natureza sancionatória.

No Município de São Paulo, também há previsão da aplicação da verdade sabida, para os casos de repreensão e de suspensão de até cinco dias, conforme artigos 185 a 187, da Lei municipal $n^{\circ} 8.989 / 79$, com prescrição de prazo para a defesa de três dias. No entanto, ainda que prevista a oportunidade de defesa, esta é considerada insuficiente no que tange ao cumprimento dos princípios do contraditório, ampla defesa e devido processo legal. Impõe-se a compatibilização à Constituição Federal. Nesse sentido, a lição de Edmir Netto de Araújo $^{271}$,

269 ARAÚJO, Edmir Netto de. Curso de Direito Administrativo. 5. ed. São Paulo: Saraiva, 2010. p. 918.

270 “Artigo 253 - A pena de repreensão será aplicada por escrito, nos casos de indisciplina ou falta de cumprimento dos deveres. Artigo 254 - A pena de suspensão, que não excederá 90 (noventa) dias, será aplicada em caso de falta grave ou de reincidência”. Lei 10261/68. Disponível em: $<$ http://www.al.sp.gov.br/repositorio/legislacao/lei/1968/lei\%20n.10.261,\%20de\%2028.10.1968.htm>. Acesso em: 28 out. 2012 .

271 ARAÚJO, Edmir Netto de. Curso de Direito Administrativo. 5. ed. São Paulo: Saraiva, 2010. p. 919. 
Mesmo no Estatuto do Município de São Paulo [...] que admitia a verdade sabida também para os casos de repreensão e suspensão até cinco dias (arts. 185 a 187), mas com defesa no prazo de três dias (art. 187, $\S \S 1^{\circ}, 3^{\circ}$ e $4^{\circ}$ ) deve-se proceder à compatibilização com o texto constitucional, ou então banir da ordem jurídica em definitivo, o instituto, utilizando-se somente a sindicância ou o processo [...].

Merece destaque no seio dos processos administrativos disciplinares a denominada Sindicância, considerada processo preparatório e de apuração, em geral, precursor do processo sancionador, apesar de, em alguns casos, poder servir para aplicação de pena disciplinar, desde que resguardados os princípios da ampla defesa e do contraditório.

Sergio Ferraz e Adilson de Abreu Dallari ${ }^{272}$ conceituam a Sindicância como "[...] um processo e um procedimento administrativo sumários". E complementam:

Serve ela para, de forma sumária e expedita, promover uma investigação preliminar a respeito de fatos e atos que devam ser alvo de atuação administrativa. Como processo administrativo, encarta-se ela no conceito que antes apresentamos [...], surgindo como uma relação jurídica tendente à efetivação da aplicação de penalidades expressamente traçadas na lei, como passíveis de configurarem sua conclusão. Como procedimento administrativo, traduz-se ela numa sucessão de atos de apuração de suposta irregularidade disciplinar, da qual resultará o arquivamento da iniciativa ou a instauração do processo administrativo disciplinar[...].

Para Edmir Netto de Araújo ${ }^{273}$, a Sindicância constitui “[...] meio de apuração de ilícito administrativo e respectiva responsabilização (sindicância acusatória), ou ainda instrumento para investigação de irregularidades nos serviços da Administração (sindicância averiguatória), já envolve providências um pouco mais complexas".

Em linhas gerais, aduz o administrativista ${ }^{274}$ :

A sindicância, realizada por Comissão ou mesmo somente por um responsável (sindicantes) em certos casos, poderá concluir pela inexistência de irregularidade, ou de falta, ou negação da autoria, caso em que não haverá processo administrativo subsequente, arquivando-se o expediente; ou então, evidenciar a exigência de imediata instauração de processo administrativo para apuração da responsabilidade e consequente penalização do funcionário, nas faltas mais graves que ensejam penalidades expulsivas. Conforme a falta, poderá também sugerir à autoridade competente a adoção de providências para a responsabilização criminal (além da disciplinar) do indiciado, independentemente da instauração e do desfecho do processo administrativo. Finalmente, poderá sugerir a aplicação de penalidades para as quais não seja exigido o processo administrativo, e principalmente após a 
Constituição de 1988, garantindo-se ao indiciado o contraditório e ampla defesa.

No âmbito do direito positivo federal, a Lei $n^{\circ} 8.112 / 90$ abriga a sindicância nos seus artigos 143 e seguintes ${ }^{275}$. E esta poderá resultar na aplicação da penalidade de advertência ou de suspensão de até 30 dias, que poderá ser convertida em multa, resguardando-se a ampla defesa e o contraditório. É viável que represente mero processo preparatório, destinado à apuração prévia de irregularidades, antecedendo o processo administrativo que aloja as penalidades mais gravosas, ou ter como fim o arquivamento do procedimento, quando da apreciação dos fatos não resulte justificativa para outras medidas.

Observa Edmir Netto de Araújo ${ }^{276}$ que "A realização dessa sindicância deve ser objetiva, rápida e precisa". E mais, registra: "Pode ser sigilosa, quando a publicidade for prejudicial (devidamente comprovada a hipótese) à apuração dos fatos, estando ainda em caráter investigatório apenas, para que não seja infringido o princípio constitucional da publicidade dos atos da Administração". No tocante à oitiva do servidor envolvido, acrescenta: "Quanto à audiência do sindicado, entendemo-la obrigatória pelo princípio da publicidade constante do artigo $5^{\circ}$ da $\mathrm{CF}$, não havendo sindicado, como é óbvio, quando a sindicância ainda não tem indiciado, objetivando apenas verificação de irregularidades, em geral”.

\footnotetext{
275 Algumas das principais previsões sobre a Sindicância situadas na Lei 8.112/90: “Título V - Do Processo Administrativo Disciplinar - Capítulo I - Disposições Gerais Art. 143. A autoridade que tiver ciência de irregularidade no serviço público é obrigada a promover a sua apuração imediata, mediante sindicância ou processo administrativo disciplinar, assegurada ao acusado ampla defesa. ... Art. 145. Da sindicância poderá resultar: I - arquivamento do processo; II - aplicação de penalidade de advertência ou suspensão de até 30 (trinta) dias; III - instauração de processo disciplinar. Parágrafo único. O prazo para conclusão da sindicância não excederá 30 (trinta) dias, podendo ser prorrogado por igual período, a critério da autoridade superior. Art. 146. Sempre que o ilícito praticado pelo servidor ensejar a imposição de penalidade de suspensão por mais de 30 (trinta) dias, de demissão, cassação de aposentadoria ou disponibilidade, ou destituição de cargo em comissão, será obrigatória a instauração de processo disciplinar. [...] Art. 149. O processo disciplinar será conduzido por comissão composta de três servidores estáveis designados pela autoridade competente, observado o disposto no § 3 o do art. 143, que indicará, dentre eles, o seu presidente, que deverá ser ocupante de cargo efetivo superior ou de mesmo nível, ou ter nível de escolaridade igual ou superior ao do indiciado. (Redação dada pela Lei $\mathrm{n}^{\circ}$ 9.527, de 10.12.97). ... § 1 o A Comissão terá como secretário servidor designado pelo seu presidente, podendo a indicação recair em um de seus membros. § $2 \underline{\underline{0}}$ Não poderá participar de comissão de sindicância ou de inquérito, cônjuge, companheiro ou parente do acusado, consanguíneo ou afim, em linha reta ou colateral, até o terceiro grau". Disponível em: $<$ http://www.planalto.gov.br/ccivil 03/leis/L8112cons.htm>. Acesso em: 28 out. 2012.
}

276 ARAÚJO, Edmir Netto de. Curso de Direito Administrativo. 5. ed. São Paulo: Saraiva, 2010. p. 921. 
No que concerne ao Estado de São Paulo, a Lei no $10.261 / 68$, com as alterações da Lei Complementar $n^{\circ} 942 / 2003$, cuidou da sindicância nos artigos 268 a $273^{277}$, de forma similar ao tratamento dado pela norma federal.

Criou, ademais, a figura específica da Apuração Preliminar $^{278}$, que pode anteceder a própria sindicância.

Assim, a Sindicância, na previsão da regra estadual disciplinar paulista, consiste no meio de apuração das penalidades mais leves, as quais não estejam compreendidas taxativamente como objeto de processo administrativo disciplinar, isto é, as penas de repreensão, suspensão e multa, cabendo a este processo administrativo, denominado de apuração preliminar, análise de caráter investigativo, sem a existência de um indiciado determinado. Para presidir os trabalhos da sindicância, a partir da Lei Complementar $n^{\circ}$ 942/2003, deve ser designado Procurador do Estado, atuando no âmbito da ProcuradoriaGeral do Estado.

No Município de São Paulo, a Lei no 8.989/79, alterada pela Lei no 13.519/2003 e regulamentada pelo Decreto $n^{\circ} 43.233 / 2003$, disciplina a sindicância e arrola as espécies dos procedimentos sumários para apurar eventuais ilícitos administrativos mais leves, não

277 Previsões referentes à Sindicância, no âmbito da Lei Estadual n ${ }^{\circ}$ 10.261/68, com atualização da Lei Complementar no 942/2003: "Do Procedimento Disciplinar (NR) - CAPÍTULO I - Das Disposições Gerais (NR) - Artigo 268 - A apuração das infrações será feita mediante sindicância ou processo administrativo, assegurados o contraditório e a ampla defesa. (NR) Artigo 269 - Será instaurada sindicância quando a falta disciplinar, por sua natureza, possa determinar as penas de repreensão, suspensão ou multa. (NR) Artigo 270 - Será obrigatório o processo administrativo quando a falta disciplinar, por sua natureza, possa determinar as penas 'de demissão, de demissão a bem do serviço público e de cassação de aposentadoria ou disponibilidade. (NR) Artigo 271 - Os procedimentos disciplinares punitivos serão realizados pela Procuradoria Geral do Estado e presididos por Procurador do Estado confirmado na carreira. (NR) CAPÍTULO II - Da Sindicância Artigo 272 - São competentes para determinar a instauração de sindicância as autoridades enumeradas no artigo 260. (NR) Parágrafo único - Instaurada a sindicância, o Procurador do Estado que a presidir comunicará o fato ao órgão setorial de pessoal. (NR) Artigo 273 - Aplicam-se à sindicância as regras previstas nesta lei complementar para o processo administrativo, com as seguintes modificações: (NR) I - a autoridade sindicante e cada acusado poderão arrolar até 3 (três) testemunhas; (NR) II - a sindicância deverá estar concluída no prazo de 60 (sessenta) dias; (NR) III - com o relatório, a sindicância será enviada à autoridade competente para a decisão. (NR)". Disponível em: $\quad<$ http://www.al.sp.gov.br/repositorio/legislacao/lei\%20complementar/2003/lei\%20complementar\%20n.942, $\% 20 \mathrm{de} \% 2006.06 .2003 . \mathrm{html}>$. Acesso em: 28 out. 2012.

278 Com relação à Apuração Preliminar, segue previsão no âmbito da Lei Estadual $n^{\circ}$ 10.261/68, com atualização da Lei Complementar no 942/2003: “Artigo 265 - A autoridade realizará apuração preliminar, de natureza simplesmente investigativa, quando a infração não estiver suficientemente caracterizada ou definida autoria. (NR) $\S 1^{\circ}$ - A apuração preliminar deverá ser concluída no prazo de 30 (trinta) dias. (NR) $\S 2^{\circ}$ - Não concluída no prazo a apuração, a autoridade deverá imediatamente encaminhar ao Chefe de Gabinete relatório das diligências realizadas e definir o tempo necessário para o término dos trabalhos. (NR) $\S 3^{\circ}-$ Ao concluir a apuração preliminar, a autoridade deverá opinar fundamentadamente pelo arquivamento ou pela instauração de sindicância ou de processo administrativo. (NR)". Disponível em: $<$ http://www.al.sp.gov.br/repositorio/legislacao/lei\%20complementar/2003/lei\%20complementar\%20n.942,\%20 de\%2006.06.2003.html>. Acesso em: 28 out. 2012. 
passíveis de abertura de processo administrativo, quais sejam: (1) o processo sumário ${ }^{279}$, destinado a apurar as condutas disciplinares não passíveis de demissão, excetuadas aquelas objeto do procedimento sumário mencionado no seu artigo 187, isto é, puníveis com repreensão e suspensão até 05 (cinco) dias; (2) a sindicância visando apuração simples e genérica, como uma apuração preliminar ${ }^{280}$, consoante preceitos compreendidos nos $\S \S 1^{\circ}$ e $2^{\circ}$, do artigo 201, da Lei 8989/79; (3) a sindicância preparativa do inquérito administrativo ${ }^{281}$, quando ausentes elementos de autoria e materialidade da falta disciplinar, preconizada no artigo 203 do diploma legal.

Interessante o tratamento da sindicância preparativa do inquérito administrativo. É que nesta restam marginalizados os princípios do contraditório e da ampla defesa, ex vi do disposto no artigo 204, da Lei $\mathrm{n}^{0}$ 8.989/79, que os exclui expressamente: “Art. 204 - A sindicância não comporta o contraditório e tem caráter sigiloso, devendo ser ouvidos, no entanto, os envolvidos nos fatos".

Salienta-se, todavia, que indigitado dispositivo, ainda que em sede de investigação sigilosa, ao excluir do eventual sindicado a oportunidade de defesa e de contraditório, afronta tais princípios, a par de lesar o cânone da publicidade e o devido processo legal. Por isso, aponta Edmir Netto de Araújo ${ }^{282}$ : “[...] É, no entanto, duvidosa a possibilidade de subtração ao exame do indiciado da decisão instauradora do inquérito, pelo princípio constitucional da publicidade".

279 "DO PROCESSO SUMÁRIO - Art. 202 - Instaura-se o processo sumário quando a falta disciplinar, pelas proporções ou pela natureza, não comportar demissão, ressalvado o disposto no artigo 187. Parágrafo único - No processo sumário, após a instrução, dar-se-á vista ao funcionário para apresentação de defesa em 5 (cinco) dias, seguindo-se a decisão". Disponível em: <http://www.prefeitura.sp.gov.br/cidade/secretarias/ upload/chamadas/estatuto_1289412340.pdf>. Acesso em: 28 out. 2012.

280 “Art. 201 - A autoridade que tiver ciência de irregularidades no serviço público é obrigada a tomar providências objetivando a apuração dos fatos e responsabilidades. $\S 1^{\circ}$ - As providências de apuração terão início imediato após o conhecimento dos fatos e serão adotadas na unidade onde estes ocorreram, consistindo na elaboração de relatório circunstanciado e conclusivo sobre os fatos, instruído com a oitiva dos envolvidos e das testemunhas, além de outras provas indispensáveis ao seu esclarecimento.§ $1^{\circ}$ - As providências de apuração terão início logo em seguida ao conhecimento dos fatos e serão tomadas na unidade onde estes ocorreram, devendo consistir, no mínimo, em relatório circunstanciado sobre o que se verificou. $\S 2^{\circ}$ - As providências de apuração previstas no parágrafo $1^{\circ}$ deste artigo serão adotadas pela autoridade que tiver ciência da irregularidade, podendo ser cometidas a funcionário ou comissão de funcionários". Disponível em: $<$ http://www.prefeitura.sp.gov.br/cidade/secretarias/upload/chamadas/estatuto_1289412340.pdf $>$. Acesso em: 28 out. 2012.

281 "DA SINDICÂNCIA - Art. 203 - A sindicância é peça preliminar e informativa do inquérito administrativo, devendo ser promovida quando os fatos não estiverem definidos ou faltarem elementos indicativos da autoria". Disponível em: <http://www.prefeitura.sp.gov.br/cidade/secretarias/ upload/chamadas/estatuto_1289412340.pdf>. Acesso em: 28 out. 2012.

282 ARAÚJO, Edmir Netto de. Curso de Direito Administrativo. 5. ed. São Paulo: Saraiva, 2010. p. 924. 
Outra das ferramentas de alta relevância se traduz no Processo Administrativo que tem por objeto a apreciação de ilícitos administrativos disciplinares, funcionais e, até mesmo, os denominados ilícitos administrativos que produzem reflexos no campo penal e demandam a aplicação de sanções disciplinares mais severas. Este, apesar da gravidade dos fatos em apuração, deve respeitar, em todo seu percurso, os princípios da ampla defesa e do contraditório, bem como do devido processo legal e todas as suas garantias.

A Lei $\mathrm{n}^{\circ}$ 8.112/90, que versa sobre o regime jurídico-disciplinar dos servidores civis federais, exige o processo administrativo para a aplicação das penas de suspensão por mais de trinta dias, destituição de cargo em comissão, demissão, cassação de aposentadoria e para a disponibilidade, conforme estabelecido no artigo $146^{283}$. Preconiza para a sua tramitação três distintas fases, afigurando-se o inquérito administrativo ${ }^{284}$ uma delas, a seu turno integrado pelas etapas de instrução, defesa e relatório.

No Estado de São Paulo, a Lei $n^{0}$ 10.261/68, com as alterações da Lei Complementar $n^{\circ}$ 942/2003, instituiu a obrigatoriedade do processo administrativo nos moldes do artigo 270: “Artigo 270 - Será obrigatório o processo administrativo quando a falta disciplinar, por sua natureza, possa determinar as penas de demissão, de demissão a bem do serviço público e de cassação de aposentadoria ou disponibilidade".

No Município de São Paulo, a Lei $n^{\circ} 8.989 / 79$, prevê o processo administrativo sob a designação de inquérito administrativo, na forma estabelecida no seu artigo 207: "Instaura-se inquérito administrativo quando a falta disciplinar, por sua natureza, possa determinar a pena de demissão". Ainda, em território municipal, esclarecedores os preceitos contidos nos artigos 83 e 84 do Decreto $n^{\circ} 43.233 / 2003$, in verbis:

Art. 83. O procedimento disciplinar comum é o Inquérito Administrativo, cujo rito será aplicado subsidiariamente aos demais. Art. 84. Instaurar-se-á Inquérito Administrativo quando a falta disciplinar, por sua natureza, puder determinar a dispensa dos servidores admitidos estáveis ou a demissão, a cassação de aposentadoria ou de disponibilidade dos efetivos ou comissionados.

A esse passo não há como deixar de fazer alusão, mais uma vez, à incidência da Súmula Vinculante $n^{\circ}$ 05, do Supremo Tribunal Federal, que aborda a questão relativa a não

Previsão da Lei 8112/90: “Art.146.Sempre que o ilícito praticado pelo servidor ensejar a imposição de penalidade de suspensão por mais de 30 (trinta) dias, de demissão, cassação de aposentadoria ou disponibilidade, ou destituição de cargo em comissão, será obrigatória a instauração de processo disciplinar". Disponível em: $<$ http://www.planalto.gov.br/ccivil_03/leis/L8112cons.htm>. Acesso em: 28 out. 2012.

284 Previsão da Lei 8112/90: “Art.151. O processo disciplinar se desenvolve nas seguintes fases: Iinstauração, com a publicação do ato que constituir a comissão; II-inquérito administrativo, que compreende instrução, defesa e relatório; III-julgamento". Disponível em: < $\underline{\text { http://www.planalto.gov.br/ }}$ ccivil_03/leis/L8112cons.htm>. Acesso em: 28 out. 2012. 
ofensa à Constituição Federal pela falta de defesa técnica produzida por advogado no decorrer dos processos disciplinares. Aspecto particular e sensível a todo o trâmite processual, o tópico é tratado pelos diferentes diplomas legais seguindo a orientação de que, embora não ofenda a Constituição Federal a ausência de advogado e a ausência da respectiva defesa técnica, esta situação, no âmbito do processo disciplinar, pode acarretar ilegalidade, dependendo da previsão normativa atinente.

Destarte, a Lei $\mathrm{n}^{\mathrm{o}} 8.112 / 90$ não prevê a obrigatoriedade do advogado para realização de defesa técnica. Porém, em caso de revelia, exige a nomeação de um defensor o servidor revel, como se deduz da leitura dos artigos 156 e $164, \S \S 1^{\circ}$ e $2^{\circ}$, na redação dada pela Lei $n^{\circ} 9.527 / 97$ :

Art.156. É assegurado ao servidor o direito de acompanhar o processo pessoalmente ou por intermédio de procurador, arrolar e reinquirir testemunhas, produzir provas e contraprovas e formular quesitos, quando se tratar de prova pericial. [...] Art.164. Considerar-se-á revel o indiciado que, regularmente citado, não apresentar defesa no prazo legal. §1ํㅡ슬 revelia será declarada, por termo, nos autos do processo e devolverá o prazo para a defesa. $\S 2^{\circ}$-Para defender o indiciado revel, a autoridade instauradora do processo designará um servidor como defensor dativo, que deverá ser ocupante de cargo efetivo superior ou de mesmo nível, ou ter nível de escolaridade igual ou superior ao do indiciado.

Em contrapartida, encampando o entendimento da Súmula $\mathrm{n}^{\circ} 343$, do Superior Tribunal de Justiça ${ }^{285}$, os estatutos estadual e municipal exigem a presença de advogado e a respectiva defesa técnica no âmbito dos processos administrativos, sob pena de ilegalidade.

No Estado de São Paulo, a Lei $n^{0}$ 10.261/68, com as alterações da Lei Complementar $n^{\circ} 942 / 2003$, preconiza a defesa técnica por força de preceitos claros, ex vi dos dispositivos a seguir transcritos:

Artigo 278 - Autuada a portaria e demais peças preexistentes, designará o presidente dia e hora para audiência de interrogatório, determinando a citação do acusado e a notificação do denunciante, se houver. $\S 1^{\circ}-\mathrm{O}$ mandado de citação deverá conter: 4 - esclarecimento de que o acusado será defendido por advogado dativo, caso não constitua advogado próprio; Artigo 282 - O acusado poderá constituir advogado que o representará em todos os atos e termos do processo. $\S 3^{\circ}$ - Não tendo o acusado recursos financeiros ou negando-se a constituir advogado, o presidente nomeará advogado dativo. Artigo 292 - Encerrada a fase probatória, dar-se-á vista dos autos à defesa, que poderá apresentar alegações finais, no prazo de 7 (sete) dias. Parágrafo

285 STJ Súmula no 343 - 12/09/2007 - DJ 21/09/2007 - Obrigatoriedade - Presença de Advogado - Processo Administrativo Disciplinar. "É obrigatória a presença de advogado em todas as fases do processo administrativo disciplinar". 
único - Não apresentadas no prazo as alegações finais, o presidente designará advogado dativo, assinando-lhe novo prazo.

No Município de São Paulo, a Lei 8989/79, no parágrafo único do seu artigo 212, determina a obrigatoriedade de defesa técnica de advogado no âmbito dos processos administrativos por ela regulados: "Art. 212 - Nenhum funcionário será processado sem assistência de defensor habilitado. Parágrafo único - Se o funcionário não constituir advogado, ser-lhe-á dado defensor na pessoa de Procurador Municipal”.

Há outro aspecto meritório de análise, ainda de forma genérica. Diz respeito aos institutos do recurso e da revisão. Isto porque a decisão administrativa inicial poderá sofrer revisão e vir a ser pleiteada sua reforma. A atividade humana pode apresentar erros ou falhas e, nesta esteira, realça Edmir Netto de Araújo ${ }^{286}$ que "O Direito, como obra humana que é, geralmente garante, sob determinadas condições, esse reexame, em atenção à falibilidade dos julgamentos humanos e à possibilidade de apreciação falha do direito e dos fatos".

Focalizando o estudo do reexame, sob a perspectiva do processo administrativo disciplinar $^{287}$, Edmir Netto de Araújo ${ }^{288}$ cita três expedientes pelos quais se pode buscar a reapreciação na esfera administrativa: (1) o pedido de reconsideração, consistente na solicitação à própria autoridade que proferiu a decisão, para que reexamine mais atentamente esse julgamento, visando sua modificação, voltando atrás em sua posição inicial; (2) o recurso hierárquico, que supõe a existência de autoridade superior, na escala de subordinação hierárquica, àquela que proferiu a decisão, para que realize, depois de pedido de reconsideração não provido, a correção do ato administrativo impugnado; (3) a revisão administrativa, calcada sob inspiração direta da revisão criminal prevista no Código de Processo Penal, consistente na nova análise de processo administrativo que tenha resultado punição disciplinar, quando foram aduzidos novos fatos ou circunstâncias suscetíveis de justificar a inocência do punido ou a inadequação da penalidade aplicada.

Ressalta o administrativista ${ }^{289}$ que, diferentemente dos processos judiciais, “[...] a autoridade administrativa não está integralmente sujeita à regra proibitiva de decisões ultra ou extra petita, podendo em certos casos modificar a decisão até mesmo contra pretensão do recorrente". Os institutos de reexame da decisão administrativa disciplinar estão previstos nos

\footnotetext{
286 ARAÚJO, Edmir Netto de. Curso de Direito Administrativo. 5. ed. São Paulo: Saraiva, 2010. p. 944.

287 Ressalta-se que tais institutos de reexame não são exclusivos do processo administrativo disciplinar, estando presentes em outras regras que regulem processos administrativos de outras espécies.

288 ARAÚJO, Edmir Netto de. Curso de Direito Administrativo. 5. ed. São Paulo: Saraiva, 2010. p. 945.

289 ARAÚJO, Edmir Netto de. Curso de Direito Administrativo. 5. ed. São Paulo: Saraiva, 2010. p. 944.
} 
diplomas legais que regulam as matérias disciplinares em destaque. Apresentam, quanto ao tratamento da matéria, pontos em comum e divergentes, não sendo objeto, no entanto, da presente dissertação, a análise mais aprofundada das particularidades respectivas desses institutos. 


\section{DAS NULIDADES NO PROCESSO ADMINISTRATIVO}

\subsection{CONSIDERAÇÕES PRELIMINARES - O DEVER DE RECOMPOR A LEGALIDADE}

Em contraposição ao exercício arbitrário e buscando consolidar a ideia do governo das leis, evitando a concentração do poder nas mãos do governante, o modelo de Estado de Direito, a partir da formulação alemã do Rechtstaat, instala-se em todas as partes, conquistando a confiança das sociedades no afã de resguardar a liberdade dos indivíduos diante do Poder. A fórmula, como registra Carl Schmitt no seu clássico Teoria de la Constitución, tem por objetivo aniquilar a figura do Estado de força, o Estado de polícia, e contrapor a liberdade do cidadão à ideia predominante até o século XVIII de glória do Estado $^{290}$.

Entre nós, Manoel Gonçalves Ferreira Filho oferece um amplo estudo sobre este peculiar instrumento de limitação do poder, explicitando a sua origem na velha aspiração de um governo de leis e não de homens, perspectiva já prevista na Declaração de Direitos adotada pelo Estado norte-americano de Massachusetts, em 1779. E mais, acrescenta: “A reivindicação de um Estado obediente ao Direito e que atue pelo direito é generalizada nas revoluções liberais. [...] O primeiro princípio do Estado de Direito e, sem dúvida, o básico dentre os três que o caracterizam, é o princípio da legalidade". ${ }^{291}$

Destaca-se, portanto, no contexto da fórmula em apreço, a importância da legalidade como barreira ao Estado e garantia aos cidadãos. Nesta linha, encontra-se a observação de Schmitt de que somente poderá ser considerado como Estado de Direito a ordem jurídica que assegure a abstenção do Estado de se imiscuir na "esfera da liberdade individual a não ser com base em uma lei". ${ }^{292}$

Não é outro o entendimento do professor Edmir Netto de Araújo ${ }^{293}$, ao registrar:

\footnotetext{
290 SCHMITT, Carl. Teoria de la Constitución. México: Nacional. p. 150 e seguintes.

291 FERREIRA FILHO, Manoel Gonçalves. Princípios Fundamentais do Direito Constitucional. 2. ed. São Paulo: Saraiva, 2009. p. 181.

292 SCHMITT, Carl. Teoria de la Constitución. México: Nacional. p. 151.

293 ARAÚJO, Edmir Netto de. Curso de Direito Administrativo. 5. ed. revisada e atualizada. São Paulo: Saraiva, 2010. p. 73.
} 
[...] A grande conquista [...], decorrente das revoluções liberais, foi o Estado também submeter-se ao império da lei, deixando de ser o Estado policialesco dos regimes absolutistas. O Estado e suas autoridades não podem e não devem desobedecer à lei, dogma democrático ("suporta a lei que fizeste") que visa combater o arbítrio [...].

Sob o comando da Constituição Federal brasileira de 5 de outubro de 1988, comum é o entendimento, com respaldo no disposto no inciso II do seu artigo $5^{\circ}$, de que a legalidade opera de forma a permitir aos indivíduos a liberdade desde que não proibida pela lei ou de que somente a lei pode obrigar a fazer ou a deixar de fazer alguma coisa. Já ao Poder Público, a legalidade significa que este somente poderá agir desde que a lei o permita ou determine de forma expressa, posição que decorre, ainda, do preceito inscrito no caput do artigo 37 do Estatuto Fundamental.

Há também que se destacar que no Brasil adotou-se o sentido da legalidade expandida, considerando o próprio preâmbulo da Constituição de 1988, que possui valores como igualdade e segurança, bem como a parte introdutória da referida Carta Magna de 1988, (artigos $1^{\circ}$ e $4^{\circ}$ ), que menciona princípios e objetivos que constituem verdadeiros parâmetros de legalidade a se impor aos Poderes Executivo, Legislativo e Judiciário. Nesta esteira, conclui Di Pietro 294 , “[...] Vale dizer que, hoje, o princípio da legalidade tem uma abrangência muito maior porque exige submissão ao Direito".

Destarte, em nosso ambiente, sob o comando do modelo de Estado de Direito, a atuação do Poder Executivo, isto é, da Administração, em seu sentido amplo, há que se conformar à lei em sua concepção também mais abrangente, conforme apontado acima.

Ressalta a evidência, pois, a importância do conceito de legalidade para a definição da atividade administrativa. Esta resta vinculada à legalidade e, se atingida por algum defeito, nasce para a Administração o dever de recompor a legalidade lesada ou jamais existente.

Hely Lopes Meirelles ${ }^{295}$ pontua o tema da seguinte forma

[...] A Administração Pública, como instituição destinada a realizar o direito e a propiciar o bem comum, não pode agir fora das normas jurídicas e dos princípios constitucionais explícitos e implícitos, com destaque para a moralidade administrativa, nem eleger os fins sociais a que sua ação se dirige. A legitimidade da atividade decorre do respeito à lei e aos referidos princípios. Se, por erro, culpa, dolo ou interesses escusos de seus agentes, a

294 DI PIETRO, Maria Sylvia Zanella. Direito Administrativo. 25. ed. São Paulo: Atlas, 2012. p. 30. 
atividade do Poder Público desgarra-se da lei, divorcia-se dos princípios, é dever da Administração invalidar, espontaneamente ou mediante provocação, o próprio ato, contrário à sua finalidade, por inoportuno, inconveniente, imoral ou ilegal. Se o não fizer a tempo, poderá o interessado recorrer às vias judiciárias.

De sua parte, Celso Antônio Bandeira de Mello $^{296}$ ao examinar a questão aduz: “[...] Os atos administrativos praticados em desconformidade com as prescrições jurídicas são inválidos. A noção de invalidade é antiética à de conformidade com o Direito (validade)”.

Das ponderações acima ressalta à evidência que a atividade administrativa deve se pautar pelos ditames do ordenamento jurídico em vigor, sob pena de serem considerados os respectivos atos contrários e lesivos à ordem jurídica e, portanto, passíveis de invalidação.

Há que se considerar, porém, a possibilidade de diferentes hipóteses de vícios ou defeitos atingirem o ato administrativo; exsurge, pois, para a Administração, o dever de recompor a legalidade, subtraindo o ato viciado ou promovendo o saneamento. Oferecem relevância nesta esteira os apontamentos de Edmir Netto de Araújo: “[...] é cristalino que a verificação de ilegalidades na formação do ato administrativo pelos agentes públicos se enquadra na concepção do poder-dever administrativo de anulá-los, caso tal se inclua em seu círculo de competências, e disto não podem eximir-se, sob pena de responsabilidade". ${ }^{297}$

A questão que se coloca, destarte, refere-se ao poder-dever da Administração em restaurar a legalidade do ato administrativo.

Sensível ao tema, por mais desta vez, ressalta Edmir Netto de Araújo: ${ }^{298}$

[...] O que ocorre é que a vinculação, nesses casos, refere-se à obrigatoriedade de restaurar a legalidade e não à de invalidar ou convalidar: se a única forma de restaurar a legalidade for a invalidação, como nos atos nulos, é obvio que se trata de um dever, não podendo o administrador escolher outro caminho. Mas se for possível restaurar a legalidade quer pela anulação, quer pela correção da ilegalidade, quando possível, é claro que se trata de um poder-dever, ainda de restaurar a legalidade. Se houver dois caminhos, em que a lei "nada impôs" poderá o administrador escolher, em sua competência, o melhor meio de atingir este interesse público concreto e vinculante, que é a restauração da legalidade. ${ }^{299}$

\footnotetext{
296 BANDEIRA DE MELlO, Celso Antônio. Curso de Direito Administrativo. 29. ed. São Paulo: Malheiros, 2012. p. 469.

297 ARAÚJO, Edmir Netto de. Curso de Direito Administrativo. 5. ed. revisada e atualizada. São Paulo: Saraiva, 2010. p. 502.

298 ARAÚJO, Edmir Netto de. Curso de Direito Administrativo. 5. ed. revisada e atualizada. São Paulo: Saraiva, 2010. p. 502.

299 ARAÚJO, Edmir Netto de. Curso de Direito Administrativo. 5. ed. revisada e atualizada. São Paulo: Saraiva, 2010. p. 503.
} 
De forma diferente ao autor supra enunciado, Celso Antonio Bandeira de Mello $^{300}$, encampando doutrina de Weida Zancaner ${ }^{301}$, no que tange à possibilidade de restaurar e legalidade tanto pela anulação quanto pela convalidação do ato administrativo eivado de ilegalidade (no caso de nulidade sanável, como veremos), manifesta-se pelo dever de convalidar o ato administrativo eivado de vício, quando for possível fazê-lo, fundamentando, pois, por não haver discricionariedade na opção ${ }^{302}$.

Nessa linha, entende Weida Zancaner ${ }^{303}$ :

Em face do exposto, quando possível a convalidação dos atos viciados, a Administração não poderá negar-se a fazê-lo. Não há nesta hipótese - repitase - opção, discricionária, pois se a Administração Pública deve agir com fiel subsunção à lei, não nos parece plausível que possa ficar a critério do administrador invalidar atos, relações jurídicas, ou ambos, se existe a possibilidade de convalidá-los, pois a convalidação atende não só ao princípio da legalidade mas, sobretudo, ao da segurança jurídica, ressalvada a hipótese de ato discricionário maculado por vício de competência.

Em que pese a posição dos autores supra, optamos pela doutrina de Edmir Netto de Araújo ${ }^{304}$, a qual assevera pela opção entre anular e convalidar o ato administrativo eivado de ilegalidade, cabendo à valoração interna da Administração a seleção entre uma e outra das vias, obviamente, de acordo com as peculiaridades do caso concreto em análise.

Edmir Netto de Araújo ${ }^{305}$ assim pontua sua posição, que acompanhamos:

É mais simples constatar que, no caso da anulação, o "poder" da Súmula STF $n^{\circ} 473$ significa uma faculdade, escolha entre anular ou não anular o ato quando a nulidade é relativa, faculdade esta que inexiste quando a nulidade é absoluta, insanável, porque o dever da autoridade [como, aliás, afirmou

300 BANDEIRA DE MELlO, Celso Antônio. Curso de Direito Administrativo. 29. ed. São Paulo: Malheiros, 2012. p. 483-485;

301 ZANCANER, Weida. Da convalidação e da Invalidação dos atos administrativos. São Paulo: RT, 1990. p. 53-57.

302 Di Pietro, a partir da $11^{\text {a }}$ edição de seu livro, segue o posicionamento de Celso Antonio Bandeira de Mello e Weida Zancaner no que tange ao dever de convalidação do ato administrativo eivado de nulidade, exceto o caso de ato discricionário praticado por autoridade incompetente (DI PIETRO, Maria Sylvia Zanella. Direito Administrativo. 25. ed. São Paulo: Atlas, 2012. p. 253 e seguintes).

303 ZANCANER, Weida. Da convalidação e da Invalidação dos atos administrativos. São Paulo: RT, 1990. p. 56-57.

304 Para um estudo aprofundado sobre as diferentes posições da doutrina de Direito Administrativo brasileira e a questão do dever de convalidar os atos administrativos eivados de ilegalidade vide: ARAÚJO, Edmir Netto de. A convalidação dos atos administrativos e as leis de processo administrativo. In: NOHARA, Irene Patrícia; MORAES FILHO, Marco Antônio Praxedes de (Orgs.). Processo Administrativo. Temas Polêmicos da Lei 9.784/99.. São Paulo: Atlas, 2011.p. 43-66.

305 ARAÚJO, Edmir Netto de. A convalidação dos atos administrativos e as leis de processo administrativo. In: NOHARA, Irene Patrícia; MORAES FILHO, Marco Antônio Praxedes de (Orgs.). Processo Administrativo. Temas Polêmicos da Lei 9.784/99.. São Paulo: Atlas, 2011. p. 43-66. 
Celso Antonio Bandeira de Mello, citado anteriormente], frente a uma nulidade, é restaurar a legalidade agredida, e não anular, somente, como parecem indicar as leis ora examinadas, e também porque a Administração pode recompor essa legalidade tanto anulando como convalidando o ato relativamente nulo (quando a nulidade é relativa).

De toda forma, uma vez reconhecido o sentido obrigatório da Administração em recompor a legalidade, surge, ao mesmo tempo, uma delicada questão a ser enfrentada, isto é, referido poder-dever da Administração seria ilimitado e infinito mesmo diante de uma interpretação conflituosa de princípios do direito ou diante do aspecto temporal no qual se baseia a própria segurança jurídica?

De outra perspectiva, o que fazer quando nasce para a Administração o dever de recompor a legalidade em uma circunstância na qual os efeitos do ato ilegal tenham se consolidado no mundo fático, mormente em favor de terceiros de boa-fé?

Hely Lopes Meirelles ${ }^{306}$, neste ponto, faz menção ao tema da prescrição em direito administrativo e assinala que

Atualmente, a doutrina sustenta a necessidade de haver um prazo para a anulação do ato administrativo. Pouco a pouco, a jurisprudência vem adotando entendimentos que mantêm atos ilegítimos praticados e operantes há longo tempo e que já produziram efeitos perante terceiros de boa-fé. Esse entendimento jurisprudencial arrima-se na necessidade de segurança e estabilidade jurídica na atuação da Administração, até porque, [...] a Lei 9784/99 manda a Administração observar o princípio da segurança jurídica.

De sua parte, Edmir Netto de Araújo ${ }^{307}$ discute em que medida a declaração de ilegalidade ou supressão do ato viciado viria a colidir com a máxima da legalidade e aduz que:

Firmado que o interesse público que preside as atividades de invalidação e de convalidação dos atos administrativos é o da restauração da legalidade atingida pelo ato viciado, recordemos que nem sempre esse interesse público será melhor atingido (finalidade) mediante a supressão de tal ato do mundo jurídico. Por isso é que a declaração de nulidade pode ser feita pela Administração (em certas circunstâncias, deve) e essas alternativas não infirmam o princípio da legalidade; antes representam uma conciliação deste com o princípio da finalidade pública.

Portanto, revela-se de importância ímpar ter como norte o interesse público diante da constatação de defeitos ou vícios da atividade administrativa, bem como o dever de recomposição da legalidade, isso porque, por vezes, a eventual recomposição - a recondução

\footnotetext{
306 MEIRELLES, Hely Lopes. Direito Administrativo Brasileiro. 33. ed. São Paulo: RT, 2007. p. 205.

307 ARAÚJO, Edmir Netto de. Curso de Direito Administrativo. 5. ed. revisada e atualizada. São Paulo: Saraiva, 2010. p. 515.
} 
ao estado de legalidade - pode eventualmente causar efeitos que violam axiomas básicos do modelo Estado de Direito, como segurança jurídica, direitos adquiridos de terceiro de boa-fé, sendo certo afirmar que o referido poder-dever da Administração em recompor a legalidade deve observar, igualmente, o interesse público, a segurança jurídica, os administrados de boafé, as regras de prescrição e decadência, os axiomas da ampla defesa e do contraditório quando necessários, uma vez que a atividade da Administração em repor a legalidade também deve estar vinculada ao Direito.

Forçoso concluir, recorrendo aos registros de Edmir Netto de Araújo, que

[...] é poder - dever irrenunciável dos órgãos e agentes [...] o exercício do controle da legalidade de seus atos, especialmente os administrativos, o que configura interesse coletivo dos administrados e não só isso, interesse público no sentido de que os serviços públicos, a atividade administrativa, enfim, se desenvolvam de acordo com os princípios impostos pelo ordenamento jurídico ${ }^{308}$.

\subsection{O DESENVOLVIMENTO DA TEORIA DOS VÍCIOS NO DIREITO ADMINISTRATIVO}

Para se iniciar o estudo dos vícios no Direito Administrativo é necessária uma abordagem prévia dos planos de existência, validade e eficácia dos atos jurídicos, com foco no ato administrativo, considerando que, a partir do conhecimento dos elementos de existência, requisitos de validade e fatores de eficácia dos atos administrativos, alcança-se o conceito do ato perfeito, apto a produzir seus efeitos no mundo jurídico. Pois bem, visando adentrar no tema da dissertação, parece-nos necessário delinear a noção inicial do fenômeno das ilegalidades que acometem os atos administrativos, bem como suas hipóteses.

Pois bem, no tocante ao ato jurídico, Edmir Netto de Araújo ${ }^{309}$ adverte:

Para que determinada declaração de vontade seja apta a produzir os efeitos reconhecidos pelo ordenamento, configurando assim ato jurídico, deve, em primeiro lugar, existir no mundo jurídico, como declaração e como ato. Não é suficiente, entretanto, sua existência: mister se faz que seja válida, pois o ato existente mas inválido padece de vícios que não o conformam com a hipótese formulada pelo ordenamento para a produção desses efeitos. Ainda

308 ARAÚJO, Edmir Netto de. Curso de Direito Administrativo. 5. ed. revisada e atualizada. São Paulo: Saraiva, 2010. p. 524.

309 ARAÚJO, Edmir Netto de. Convalidação do ato administrativo. São Paulo: Editora Ltr, 1999. p. 15. 
assim, um ato existente e válido pode não ser apto a produzir as consequências que com a declaração de vontade se pretende, por faltar-lhe algo que the atribua operacionalidade, realizando "in concreto" aquele resultado pretendido: o ato pode ser ineficaz na ausência de certos fatores, ou estando ainda pendentes providências ou condições que são indispensáveis para sua eficácia.

Nesse sentido, complementa-se que a noção de existência, validade e eficácia é aplicável aos atos jurídicos ${ }^{310}$ em geral, pois se trata de estudo da Teoria Geral de Direito. Partindo, pois, desta teoria geral, esses indicadores terão incidências de forma peculiar no âmbito do Direito Privado, a exemplo do campo do Direito Civil e do Comercial, bem como no panorama do Direito Público, como o Penal e Trabalhista, e, logicamente, no Direito Administrativo.

Invocando a esquematização de ato jurídico que nos ensina Edmir Netto de Araújo $^{311}$, temos:

1) Fatos jurídicos voluntários: dividem-se em Atos jurídicos (efeitos jurídicos voluntários ou prescritos pelo ordenamento - adquirir, resguardar, transferir, modificar, extinguir, direitos ou situações jurídicas, e, segundo os arts. 104 e 185 do Código Civil, apenas os lícitos, e Atos ilícitos (geralmente efeitos jurídicos involuntários, como a pena ou indenização, embora possam, no caso dos crimes dolosos, ser voluntários no sentido de admitidos ou assumidos pelo agente, efeitos esses já prescritos pelo ordenamento jurídico). 2) Atos jurídicos (sentido amplo) dividem-se em Atos jurídicos em sentido estrito ou não negociais (efeitos jurídicos prescritos pelo ordenamento jurídico, podendo ser materiais de acordo com a vontade ou declaração de vontade de acordo com os efeitos prescritos pelo ordenamento, não criando vínculo jurídico não existente anteriormente; os efeitos independem da vontade, embora possam com ela coincidir), e Negócios jurídicos ou atos jurídicos negociais (consequências jurídicas desejadas pelo agente, não prescritas pelo ordenamento, mas por ele admitidas ou reconhecidas; autorregulação de interesses, criando vínculos jurídicos inexistentes antes das declarações).

Essas declarações de vontade humana, expressas segundo as normas direito, tendentes a produzir efeitos na órbita jurídica, seja o de inovar, ou de manter ou extinguir direitos, estão presentes em todos os segmentos do Direito, fenômeno a que se denominou de

\footnotetext{
310 Não temos a pretensão de nos aprofundarmos sobre o estudo dos atos jurídicos, no entanto, merecem atenção as manifestações de Edmir Netto de Araújo sobre o tema: “[...] A noção de ato jurídico é controvertida, na doutrina brasileira e mesmo na estrangeira. Alguns (doutrina unitarista) consideram ato jurídico sinônimo de negócio jurídico, incluído este último no conceito do primeiro; outros os consideram coisas separadas (corrente dualista), e outros ainda nem mencionam ato jurídico em sentido amplo. Além disso, a maior parte dos autores considera ato jurídico apenas o ato lícito, atendendo ao disposto em nosso Código Civil (arts. 104, II e 185)". ARAÚJO, Edmir Netto de. Curso de Direito Administrativo. 5. ed. revisada e atualizada. São Paulo: Saraiva, 2010. p. 466.
}

311 ARAÚJO, Edmir Netto de. Curso de Direito Administrativo. 5. ed. revisada e atualizada. São Paulo: Saraiva, 2010. p. 467. 
ato jurídico, cuja sistematização vem prescrita na obra de Edmir Netto de Araújo, consoante anteriormente explicitado. E, no que toca ao tema central da dissertação, sem mais delongas, trazemos o recorte do ato jurídico para o Direito Administrativo, delineando o que se configurou chamar de ato administrativo.

No afã de focalizar a evolução do tratamento dos vícios no Direito Administrativo, não prescinde de análise o objeto de incidência dos chamados vícios ou imperfeições, pelo que o estudo, ainda que breve, do ato administrativo é salutar, uma vez que tema central do Direito Administrativo e modo de operação da Administração. Cabe ressaltar que não é todo ato oriundo do Estado, enquanto função administrativa, que se qualifica como ato administrativo, isso porque, por vezes, a Administração edita atos chamados materiais, destinados à realização em concreto da atividade administrativa, denominados, outrossim, por Edmir Netto de Araújo, como "atos de administração"312.

Destarte, a noção de ato administrativo, espécie do ato jurídico - no consenso dos administrativistas $^{313}$, estrangeiros e brasileiros - assinala Edmir Netto de Araújo ${ }^{314}$, se traduz na “... manifestação da vontade do Estado, por agente público no exercício de suas funções, expedido em matéria administrativa, para a produção de efeitos jurídicos em relação ao serviço público ou ao interesse público". Nesse diapasão, Edmir Netto de Araújo ${ }^{315}$ conceitua o ato administrativo ${ }^{316}$ como “[...] a declaração de vontade do estado, nessa qualidade,

312 ARAÚJO, Edmir Netto de. Curso de Direito Administrativo. 5. ed. revisada e atualizada. São Paulo: Saraiva, 2010. p. 474.

313 Vide rol dos autores de Direito Administrativo elencados na nota de rodapé $\mathrm{n}^{\mathrm{o}} 26, \mathrm{p}$. 475, do Curso de Direito Administrativo de Edmir Netto de Araújo, entre eles: Georges Vedel, Jean Rivero, Marcel Waline, Massimo Severo Giannini, Umberto Fragola, Guido Zanobini, Marcello Caetano, Fritz Freiner, Recaredo Fernandez de Velasco, Rafael Bielsa, dentre os autores estrangeiros, e, dentre os autores nacionais: José Cretella Junior, Hely Lopes Meirelles, Celso Antônio Bandeira de Mello, Diogo de Figueiredo Moreira Neto, Mário Massagão, Maria Sylvia Zanella Di Pietro entre outros (ARAÚJO, Edmir Netto de. Curso de Direito Administrativo. 5. ed. revisada e atualizada. São Paulo: Saraiva, 2010. p. 475, nota de rodapé no 26.

314 ARAÚJO, Edmir Netto de. Curso de Direito Administrativo. 5. ed. revisada e atualizada. São Paulo: Saraiva, 2010. p. 475.

315 ARAÚJO, Edmir Netto de. Curso de Direito Administrativo. 5. ed. revisada e atualizada. São Paulo: Saraiva, 2010. p. 475-476.

316 Importante observar que não há, na legislação brasileira, uma definição de ato administrativo. De toda forma, vejamos os conceitos elaborados por alguns doutrinadores brasileiros: Celso Antônio Bandeira de Mello: “[...] declaração do Estado, ou de quem lhe faça as vezes, no exercício de prerrogativas públicas, manifestada mediante providências jurídicas complementares da lei a título de lhe dar cumprimento, e sujeitas a controle de legitimidade por órgãos jurisdicionais" BANDEIRA DE MELLO, Celso Antônio. Curso de Direito Administrativo. 29. ed. São Paulo: Malheiros, 2012. p. 389; Hely Lopes Meirelles: “[...] toda manifestação unilateral de vontade da Administração Pública que, agindo nessa qualidade, tenha por fim imediato adquirir, resguardar, transferir, modificar, extinguir e declarar direitos, ou impor obrigações aos administrados ou a si própria". MEIRELLES, Hely Lopes. Direito Administrativo Brasileiro. 33. ed. São Paulo: RT, 2007. p. 150; Maria Sylvia Zanella Di Pietro: “[...] declaração do Estado ou de quem o represente, que produz efeitos jurídicos imediatos, com observância da lei, sob regime jurídico de direito público e sujeita a controle pelo Poder Judiciário". DI PIETRO, Maria Sylvia Zanella. Direito Administrativo. 25. ed. São Paulo: Atlas, 2012. p.203. 
exteriorizada por agente competente e no exercício de suas funções, visando à produção de efeitos jurídicos conformes ao interesse público, com ela objetivados, determinados ou admitidos pelo ordenamento jurídico, em matéria administrativa".

Perceptível é, pois, tanto no conceito do ato administrativo, quanto de um prisma mais geral, da noção de ato administrativo presente na doutrina de Direito Administrativo, a presença de definições que se vinculam com os planos de existência, validade e eficácia. A própria noção de ato administrativo nos remete ao entendimento de que ele exista, seja válido e, por conseguinte, possa produzir seus efeitos. No entanto, o debate sobre o que se entende por ato administrativo existente, válido e eficaz originou controvérsias significativas ${ }^{317}$ no seio da doutrina.

Realizando uma espécie de análise anatômica e estrutural do ato administrativo, Edmir Netto de Araújo ${ }^{318}$ aponta que "Considerando-se ato administrativo como espécie de ato jurídico, [...], é lícito que se afirme possuírem os atos administrativos elementos, intrínsecos ou extrínsecos, que determinam sua existência, requisitos que condicionam sua validade, e atributos que propiciam sua eficácia”.

No tocante ao plano da existência do ato administrativo, Weida Zancaner ${ }^{319}$ elenca os respectivos elementos salutares, quais sejam:

[...] temos, para nós, que os elementos do ato são: conteúdo e forma. Por sua vez, constitui pressuposto de existência do ato seu objeto, o que implica dizer que um ato há de ter conteúdo e forma para existir. Necessário, também, para analisá-lo, sob o ângulo da perfeição, examinar seu pressuposto de existência, isto é, seu objeto. Com efeito, é mais que um pressuposto de validade. Sem ele o ato nem existirá, de direito. [...].

Aduz a autora ${ }^{320}$, seguindo entendimento de Zanobini, Celso Antônio Bandeira de Mello $^{321}$, Marcello Caetano e Adilson Abreu Dallari, que o plano de existência coincide com o conceito de perfeição do ato administrativo, senão vejamos:

\footnotetext{
317 No presente trabalho, não iremos nos aprofundar nos debates referentes aos diferentes conceitos de existência, validade e eficácia, apenas demonstrar como esses conceitos se relacionam com o ato administrativo.

318 ARAÚJO, Edmir Netto de. Convalidação do ato administrativo. São Paulo: Editora Ltr, 1999. p. 28.

319 ZANCANER, Weida. Da convalidação e da Invalidação dos atos administrativos. São Paulo: RT, 1990. p. 33.

320 ZANCANER, Weida. Da convalidação e da Invalidação dos atos administrativos. São Paulo: RT, 1990. p. 31.

321 A autora segue em certa medida o entendimento de Celso Antônio Bandeira de Mello, pois em que pese ambos seguirem o entendimento de que conteúdo e forma são elementos do ato administrativo que se constituem no plano de existência do ato administrativo, tornando-o perfeito, Bandeira de Mello, entende que o no conteúdo encontra-se implícito o objeto, enquanto a autora aduz que o objeto do ato administrativo deve ser desmembrado do conteúdo (ZANCANER, Weida. Da convalidação e da Invalidação dos atos administrativos. São Paulo: RT, 1990. p. 29).
} 
Forma e conteúdo são, pois, os elementos que tornam possível, juntamente com o objeto, a existência do ato administrativo. Portanto, é a conjugação dos elementos do ato - conteúdo e forma - , com seu pressuposto de existência - objeto - que nos conduz à ideia de perfeição; no entanto, neste passo, cabe uma ressalva, não há confundir a forma com a mera exteriorização material de um conteúdo. $[\ldots]^{322}$.

Edmir Netto de Araújo $^{323}$ aduz com relação ao plano de existência do ato administrativo $^{324}$ a ocorrência de elementos intrínsecos e extrínsecos e assim afirma, com relação aos elementos intrínsecos,

[...] que se contêm no interior do próprio ato administrativo, são como nos atos jurídicos-gênero, a ação ou abstenção humanas (atos comissivos e omissivos) que tomam alguma forma [...]; o objeto ou conteúdo, que é a matéria de interesse público, a relação jurídica administrativa sobre o que o ato dispõe; e a forma que tomam a ação ou abstenção humanas, condicionando-as para obter o resultado objetivado ou admitido, constituindo a declaração de vontade do Estado, assim exteriorizada pelo comportamento de seu agente.

Com relação aos elementos extrínsecos, aduz o administrativista $^{325}$ “[...] visualizados fora do ato, mas indispensáveis no plano ontológico são o agente público [...] que em nome do Estado exterioriza sua vontade normativa; e o tempo e lugar, sem os quais não há nem mesmo fato jurídico, quanto mais ato jurídico administrativo".

Destarte, o plano de existência aporta desde logo a questão de que para a análise da validade e da eficácia do ato administrativo, necessário que ele exista antes ${ }^{326}$. Para tanto, segundo os apontamentos da doutrina, deve o ato percorrer todos os elementos básicos para sua formação, entre eles, no caso do ato administrativo, a forma, o conteúdo, o objeto, o agente público, o tempo e o lugar, sendo que, estando esses elementos devidamente constituídos, sem incidência de vícios, intrínseca e extrinsecamente, certamente o ato existirá.

322 Com relação a não confusão da forma com a mera exteriorização material de um conteúdo, a autora cita o exemplo de que um auto de infração, devidamente preenchido e assinado, mas esquecido em um arquivo de uma repartição pública, não pode ser considerado ato jurídico, por não ter concluído o ciclo necessário à sua formação (ZANCANER, Weida. Da convalidação e da Invalidação dos atos administrativos. São Paulo: RT, 1990. p. 31).

323 ARAÚJO, Edmir Netto de. Convalidação do ato administrativo. São Paulo: Editora Ltr, 1999. p. 28.

324 Edmir Netto de Araújo elabora a seguinte crítica com relação aos elementos de existência do ato administrativo: "Alguns autores, como Lopes e Cretella Junior; outros, como Celso Antônio Bandeira de Mello, na linha de Zanobini, propõem que se considere o objeto a relação jurídica a que o ato se refere, e o conteúdo aquilo que, concretamente, como ele a Administração pretende dispor [...]. Mas a linha divisória é tenue [...]" (ARAÚJO, Edmir Netto de. Convalidação do ato administrativo. São Paulo: Editora Ltr, 1999. p. 28-29).

325 ARAÚJO, Edmir Netto de. Convalidação do ato administrativo. São Paulo: Editora Ltr, 1999. p. 29.

326 De acordo com Pontes de Miranda: “[...] A questão da existência é questão prévia. Somente depois de se afirmar que existe é possível pensar-se em validade ou invalidade" (PONTES DE MIRANDA, F. C. Tratado de Direito Privado. t. IV. Rio de Janeiro: Borsói, 1954. p. 7). 
O estudo do plano da validade do ato administrativo, a seu turno, mostra-se extremamente relevante, uma vez que, distinto do plano de existência e da eficácia, a validade do ato administrativo relaciona-se à ordem jurídica com a qual ele deve se compatibilizar sob pena de ser extirpado do universo jurídico.

Edmir Netto de Araújo $^{327}$ examina este patamar de validade, asseverando que o ato administrativo deve ser informado por requisitos que o tornem apto a produzir, de forma válida, os efeitos desejados. Elenca dentre tais requisitos

[...] capacidade e competência do agente e do órgão; declaração válida (não viciada) de vontade; objeto lícito, possível e conforme o interesse público; forma legalmente prescrita ou não vedada, que correspondem em essência aos requisitos do ato jurídico em geral. E, no caso especial do ato administrativo, a estes se acrescenta o motivo existente e conforme o interesse público, simétrico ao motivo.

Para Celso Antônio Bandeira de Mello ${ }^{328}$, refutando-se a tese de Kelsen $^{329}$, que equipara o conceito de validade com o conceito de existência da norma, "[...] O Ato administrativo é válido quando foi expedido em absoluta conformidade com as exigências do sistema normativo. Vale dizer, quando se encontra adequado aos requisitos estabelecidos pela ordem jurídica. Validade, por isso, é adequação do ato às exigências normativas”. O autor330, ainda, arrola como condições de validade do ato administrativo: “1) o pressuposto subjetivo (sujeito); 2) pressupostos objetivos (motivo e requisitos procedimentais); 3) o pressuposto teleológico (finalidade); 4) o pressuposto lógico (causa); e 5) pressupostos formalísticos (formalização)".

\footnotetext{
327 ARAÚJO, Edmir Netto de. Convalidação do ato administrativo. São Paulo: Editora Ltr, 1999. p. 29-30.

328 BANDEIRA DE MELlo, Celso Antônio. Curso de Direito Administrativo. 29. ed. São Paulo: Malheiros, 2012. p. 391.

329 Celso Antônio Bandeira de Mello assim se manifesta: "Abre-se aqui um parêntese expositivo pela conveniência de refutar a tese kelseniana de que existência e validade são uma só e mesma coisa. [...] data máxima vênia, trata-se, ao nosso ver, de um equívoco [...]. Ao nosso ver, a demonstração mais cabal e irretorquível de que existência, pertinência de uma norma a dado sistema, e validade são noções absolutamente inconfundíveis tem-se no fato de que, no exame da inconstitucionalidade 'incidenter tantum', o juiz não aplica uma norma jurídica por considerá-la inconstitucional, ou seja 'carente de validade', 'inválida', mas nem por isso a expulsa do sistema (falece-lhe atribuição para fazê-lo), o que só ocorre na ação direta de inconstitucionalidade. A norma em questão continuará a existir dentro do sistema, mas sua validade terá sido questionada como algo autônomo em relação à existência e proclamada como suficiente para impedir sua aplicação ao caso concreto. [...]" (BANDEIRA DE MELLO, Celso Antônio. Curso de Direito Administrativo. 29. ed. São Paulo: Malheiros, 2012. p. 391).
}

330 BANDEIRA DE MELlo, Celso Antônio. Curso de Direito Administrativo. 29. ed. São Paulo: Malheiros, 2012. p. 396. 
O plano de eficácia do ato administrativo nos remete para a capacidade ou qualidade do ato jurídico administrativo de surtir efeitos. Nas palavras de Edmir Netto de Araújo $^{331}$, “[...] quando sobre ele (ato administrativo) incidem determinados fatores que o tornam apto para produzir efeitos, principalmente os efeitos jurídicos objetivados com a declaração de vontade".

No tocante ao ato administrativo, aliás, esclarece o administrativista ${ }^{332}$ que há outros fatores que incidem sobre a eficácia e que não são iguais aos relativos ao ato jurídico no Direito Privado. Assim se manifesta o autor:

A diferença surge na análise dos fatores gerais de eficácia do ato administrativo, pois além daqueles que incidem sobre os atos jurídicos em geral, como a verificação do evento para os atos sujeitos à condição suspensiva, o ordenamento dota os atos administrativos de certos fatores de eficácia geral, desconhecidos das relações jurídicas entre particulares, situando o Estado em posição de supremacia, fundamentada no interesse público, na relação mantida com o particular. Estes fatores, por alguns autores brasileiros denominados atributos (e realmente esta qualificação é a que melhor se ajusta), são principalmente, a imperatividade, a presunção de legitimidade e autoexecutoriedade dos atos administrativos.

O estudo do plano de eficácia se mostra deveras importante para a presente dissertação, haja vista que, em alguns casos, o ato administrativo acometido de vícios, mormente no plano da validade, poderá surtir efeitos que, dependendo da análise fática e observados os princípios da segurança jurídica e o da boa-fé, entre outros, poderão ser mantidos. $\mathrm{O}$ ato administrativo existente, mas inválido, portanto, poderá surtirá seus efeitos. Nesses termos, afirma Monica Simões ${ }^{333}$ :

Neste particular, importa, desde logo, firmar a seguinte verdade jurídica: a invalidade do ato não impede que em determinados casos excepcionais sejam preservados os efeitos até então produzidos. Vale dizer: embora a invalidação do ato produza, via de regra, efeitos ex tunc, há casos excepcionais em que os efeitos fáticos produzidos são respeitados.

Iniciou-se a exposição pela análise dos planos da existência, da validade e da eficácia dos atos jurídicos, apontando-se, também, aspectos peculiares dos referidos planos no específico âmbito do Direito Administrativo. Isso em razão do fato de que a teoria dos vícios, no Direito Administrativo, surge justamente do desatendimento dos elementos, requisitos e

\footnotetext{
331 ARAÚJO, Edmir Netto de. Negócio Jurídico Administrativo. São Paulo: Ed. RT, 1992. p. 93.

332 ARAÚJO, Edmir Netto de. Convalidação do ato administrativo. São Paulo: Editora Ltr, 1999. p. 30-31.

333 SIMÕES, Mônica Martins Toscano. O Processo Administrativo e a Invalidação de Atos Viciados. São Paulo: Malheiros, 2004. p. 121.
} 
atributos que são próprios do ato administrativo, todos fatores que criam para a Administração o dever de se compatibilizar com a legalidade.

Postas essas noções, embora breves, sobre os planos de existência, de validade e de eficácia dos atos administrativos, cabe indicar, a esse passo, a evolução do tratamento dos vícios no Direito Administrativo, oferecendo-se maior atenção ao patamar da validade do ato jurídico. Com esse propósito, pode-se afirmar que o Direito Privado influenciou o desenvolvimento da teoria dos vícios no âmbito do Direito Administrativo, embora silente e/ou tímida a doutrina quanto à efetiva e concreta transposição da teoria desenvolvida no campo do Direito privado em relação aos atos jurídicos nulos e anuláveis para a esfera do Direito Administrativo.

No Direito privado, o Código Civil de 1916 previa uma classificação das ilegalidades dos atos jurídicos, adotando uma diferenciação entre atos nulos e anuláveis, nos moldes dos artigos 145 a 158 do revogado diploma legal. A postura se manteve no Código Civil de $2002^{334}$ (artigos 166 a 184), com pequenas atualizações, ou seja, manteve-se a nuclear diferenciação entre atos jurídicos nulos e anuláveis.

Em suma, a doutrina de Direito Civil indigita como nulos os atos jurídicos nas hipóteses previstas nos artigos 166 e 167 do novo Código Civil, nulidade revestida de caráter absoluto e elenca os vícios insanáveis pelas partes, entre eles, quando:

334 Previsão atual do Novo Código Civil de 2002, referente ao tratamento das ilegalidades do ato jurídico: “Art. 166. É nulo o negócio jurídico quando: I - celebrado por pessoa absolutamente incapaz; II - for ilícito, impossível ou indeterminável o seu objeto; III - o motivo determinante, comum a ambas as partes, for ilícito; IV - não revestir a forma prescrita em lei; $\mathrm{V}$ - for preterida alguma solenidade que a lei considere essencial para a sua validade; VI - tiver por objetivo fraudar lei imperativa; VII - a lei taxativamente o declarar nulo, ou proibirlhe a prática, sem cominar sanção. Art. 167. É nulo o negócio jurídico simulado, mas subsistirá o que se dissimulou, se válido for na substância e na forma. $\S 1^{\circ}$ Haverá simulação nos negócios jurídicos quando: I aparentarem conferir ou transmitir direitos a pessoas diversas daquelas às quais realmente se conferem, ou transmitem; II - contiverem declaração, confissão, condição ou cláusula não verdadeira; III - os instrumentos particulares forem antedatados, ou pós-datados. $\S 2^{\circ}$ Ressalvam-se os direitos de terceiros de boa-fé em face dos contraentes do negócio jurídico simulado. Art. 168. As nulidades dos artigos antecedentes podem ser alegadas por qualquer interessado, ou pelo Ministério Público, quando lhe couber intervir. Parágrafo único. As nulidades devem ser pronunciadas pelo juiz, quando conhecer do negócio jurídico ou dos seus efeitos e as encontrar provadas, não lhe sendo permitido supri-las, ainda que a requerimento das partes. Art. 169. O negócio jurídico nulo não é suscetível de confirmação, nem convalesce pelo decurso do tempo. Art. 170. Se, porém, o negócio jurídico nulo contiver os requisitos de outro, subsistirá este quando o fim a que visavam as partes permitir supor que o teriam querido, se houvessem previsto a nulidade. Art. 171. Além dos casos expressamente declarados na lei, é anulável o negócio jurídico: I - por incapacidade relativa do agente; II - por vício resultante de erro, dolo, coação, estado de perigo, lesão ou fraude contra credores. Art. 172. O negócio anulável pode ser confirmado pelas partes, salvo direito de terceiro. Art. 173. O ato de confirmação deve conter a substância do negócio celebrado e a vontade expressa de mantê-lo. Art. 174. É escusada a confirmação expressa, quando o negócio já foi cumprido em parte pelo devedor, ciente do vício que o inquinava. Art. 175. A confirmação expressa, ou a execução voluntária de negócio anulável, nos termos dos arts. 172 a 174, importa a extinção de todas as ações, ou exceções, de que contra ele dispusesse o devedor. [...] Art. 177. A anulabilidade não tem efeito antes de julgada por sentença, nem se pronuncia de ofício; só os interessados a podem alegar, e aproveita exclusivamente aos que a alegarem, salvo o caso de solidariedade ou indivisibilidade". Disponível em

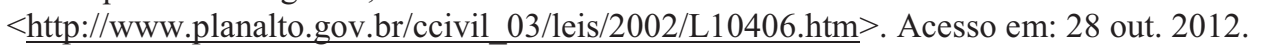


I - celebrado por pessoa absolutamente incapaz; II - for ilícito, impossível ou indeterminável o seu objeto; III - o motivo determinante, comum a ambas as partes, for ilícito; IV - não revestir a forma prescrita em lei; V - for preterida alguma solenidade que a lei considere essencial para a sua validade; VI tiver por objetivo fraudar lei imperativa; VII - a lei taxativamente o declarar nulo, ou proibir-lhe a prática, sem cominar sanção.

Inclui-se nesse rol a hipótese prevista pelo artigo 167, do referido diploma, in verbis:

Art. 167. É nulo o negócio jurídico simulado, mas subsistirá o que se dissimulou, se válido for na substância e na forma. § $1^{\circ}$ Haverá simulação nos negócios jurídicos quando: I - aparentarem conferir ou transmitir direitos a pessoas diversas daquelas às quais realmente se conferem, ou transmitem; II - contiverem declaração, confissão, condição ou cláusula não verdadeira; III - os instrumentos particulares forem antedatados, ou pós-datados.

Acrescenta-se que a nulidade absoluta prevista no Novo Código Civil de 2002 não aceita saneamento; pode ser alegada pela parte ou pelo Ministério Público e deve ser conhecida de ofício pelo juiz, sendo que seus efeitos retroagem ex tunc, senão vejamos:

Art. 168. As nulidades dos artigos antecedentes podem ser alegadas por qualquer interessado, ou pelo Ministério Público, quando lhe couber intervir. Parágrafo único. As nulidades devem ser pronunciadas pelo juiz, quando conhecer do negócio jurídico ou dos seus efeitos e as encontrar provadas, não lhe sendo permitido supri-las, ainda que a requerimento das partes. Art. 169. O negócio jurídico nulo não é suscetível de confirmação, nem convalesce pelo decurso do tempo.

Já a nulidade relativa deve ser requerida pelas partes e pode ser reparada, operando seus efeitos a partir da declaração, caso efetivada, nos termos do artigo 171 e seguintes do diploma civil:

Art. 171. Além dos casos expressamente declarados na lei, é anulável o negócio jurídico: I - por incapacidade relativa do agente; II - por vício resultante de erro, dolo, coação, estado de perigo, lesão ou fraude contra credores. Art. 172. O negócio anulável pode ser confirmado pelas partes, salvo direito de terceiro. Art. 173. O ato de confirmação deve conter a substância do negócio celebrado e a vontade expressa de mantê-lo. [...] Art. 177. A anulabilidade não tem efeito antes de julgada por sentença, nem se pronuncia de ofício; só os interessados a podem alegar, e aproveita exclusivamente aos que a alegarem, salvo o caso de solidariedade ou indivisibilidade.

A partir dessa análise, pergunta-se: É possível a transposição da teoria das ilegalidades do ato jurídico no campo do Direito Privado para o Direito Administrativo? 
O Direito Administrativo possui características tão díspares que objetam qualquer hipótese de influência da teoria das ilegalidades no Direito Privado para o Direito Administrativo?

Como já mencionado anteriormente, inclino-me a aceitar o fato de que o Direito Privado influenciou a teoria dos vícios no Direito Administrativo; no entanto, em face dos princípios da supremacia do interesse público, da indisponibilidade do interesse público e do cânone da legalidade, o tratamento dos vícios dos atos administrativos na esfera do Direito Administrativo passa a apresentar suas peculiaridades e a operar na medida de seus próprios princípios e regras condutoras, como segmento autônomo do Direito que é.

Os argumentos em favor da influência do Direito Privado na plataforma do Direito Administrativo, em particular no tocante ao tema das ilegalidades dos atos jurídicos conquanto ainda haja quem contrarie de modo veemente tal hipótese - variam, havendo notícias desde apontamentos doutrinários e jurisprudenciais datados da época imperial, e evidente se verifica a influência do direito francês e norte-americano ${ }^{335}$. De todo modo, nos parece oportuna uma perfunctória exposição sobre o percurso da teoria dos vícios do ato administrativo, como desfecho do presente capítulo. E, para tanto, apresenta-se em recorte a doutrina de Direito Administrativo desde o Império, passando pela República, apontando o entendimento plasmado pelos administrativistas clássicos sobre as ilegalidades dos atos administrativos.

Podemos encontrar nas obras de Visconde do Uruguai ${ }^{336}$ e do Conselheiro Ribas $^{337}$, respectivamente, Ensaios sobre o Direito Administrativo, datada de 1862, e Direito Administrativo Brasileiro, de 1866, uma formatação da teoria dos vícios no Direito Administrativo, sob a inspiração evidente das decisões do contencioso administrativo francês, modelo de jurisdição dúplice que, por sua vez, vigorou entre nós ${ }^{338}$, na época Imperial até a

\footnotetext{
335 Para um estudo aprofundado sobre a evolução da teoria das nulidades do Direito Administrativo, incluindo a citação da evolução da jurisprudência no que toca ao tema, vide: HORBACH, Carlos Bastide. Teoria das nulidades do ato administrativo. 2. ed. São Paulo: RT, 2010.

URUGUAI, Paulino José Soares de Souza, Visconde do. Ensaio sobre o Direito Administrativo. Brasília: Ministério da Justiça, 1997.

337 RIBAS, Antônio Joaquim. Direito Administrativo Brasileiro. S.1. Brasília: Ministério da Justiça, 1968.

338 No Brasil Imperial, sob o manto da Constituição Política do Império, datada de 25 de março de 1824 , vigorou o Conselho de Estado, nesses termos: "CAPITULO VII. Do Conselho de Estado. Art. 137. Haverá um Conselho de Estado, composto de Conselheiros vitalicios, nomeados pelo Imperador. Art. 138. O seu numero não excederá a dez. Art. 139; Não são comprehendidos neste numero os Ministros de Estado, nem estes serão reputados Conselheiros de Estado, sem especial nomeação do Imperador para este Cargo. Art. 140. Para ser Coaselheiro de Estado requerem-se as mesmas qualidades, que devem concorrer para ser Senador. Art. 14I. Os Conselheiros de Estado, antes de tomarem posse, prestarão juramento nas mãos do Imperador de - manter a Religião Catholica Apostolica Romana; observar a Constituição, e às Leis; ser fieis ao Imperador; aconselhal-o
} 
proclamação da República, sob a vigência da Constituição Política do Império do Brasil ${ }^{339}$, datada de 25 de março de 1824, com funções bastante parecidas.

Adentrando na teoria das nulidades do ato administrativo, desde o Império, Carlos Bastide Horbach ${ }^{340}$ assim se manifesta:

[...] estavam claros no contencioso administrativo do Império os requisitos dos atos administrativos, cuja inobservância acarretava a anulação, em termos muito semelhantes aos atuais, já que eram sancionadas a ausência de competência, as irregularidades de forma e as contrariedades materiais do objeto ao texto das leis e às suas finalidades, sempre tendo como modelo a jurisprudência e a doutrina francesas, como fica claro da leitura das obras de Uruguai e de Ribas, ambos Conselheiros de Estado, ricas em referências aos autores do direito administrativo francês e às decisões do Conseil d'État.

A partir do contato com as obras dos autores imperiais, ambos Conselheiros de Estado, que de forma pioneira se dedicavam ao Direito Administrativo, bem como do enfoque que Carlos Bastide Horbach realiza em seu estudo sobre as nulidades dos atos administrativos, depreende-se que, desde a época imperial, houve influência da teoria das ilegalidades dos atos jurídicos do Direito Privado para o Direito Administrativo ${ }^{341}$. Porém, mais que isso, a doutrina francesa de Direito Administrativo, em particular as decisões do Conselho de Estado francês, influenciaram de forma determinante as decisões do Conselho de Estado pátrio, órgão competente para apreciar a questão das ilegalidades no Direito Administrativo imperial, através do contencioso administrativo.

segundo suas consciencias, attendendo sómente ao bem da Nação. Art. 142. Os Conselheiros serão ouvidos em todos os negocios graves, e medidas geraes da publica Administração; principalmente sobre a declaração da Guerra, ajustes de paz, nogociações com as Nações Estrangeiras, assim como em todas as occasiões, em que o Imperador se proponha exercer qualquer das attribuições proprias do Poder Moderador, indicadas no Art. 101, á excepção da VI. Art. 143. São responsaveis os Conselheiros de Estado pelos conselhos, que derem, oppostos ás Leis, e ao interesse do Estado, manifestamente dolosos.Art. 144. O Principe Imperial, logo que tiver dezoito annos completos, será de Direito do Conselho de Estado: os demais Principes da Casa Imperial, para entrarem no Conselho de Estado ficam dependentes da nomeação do Imperador. Estes, e o Principe Imperial não entram no numero marcado no Art. 138". (N.R.: respeitada a grafia original) Disponível em: $<$ http://www.planalto.gov.br/ccivil_03/constituicao/constitui\%C3\%A7ao24.htm>. Acesso em: 28 out. 2012.

339 Conforme apontamentos de Raul Machado Horta: “A Constituição Política do Império do Brasil, de 25 de março de 1824, não emanou de Assembleia Constituinte. Tendo D. Pedro I, em 12 de novembro de 1823, dissolvido autoritariamente a Assembleia Geral Constituinte e Legislativa, que havia anteriormente convocado pelo decreto de 3 de junho de 1822, como Príncipe Regente, confiou a um Conselho de Estado composto de dez membros a incumbência de preparar Projeto de Constituição [...]. O texto constitucional, que compreendia 179 artigos e 8 títulos, dedicou 164 artigos à organização dos poderes políticos e sete artigos a enunciar as garantias dos direitos civis e políticos dos cidadãos brasileiros. Apenas o título VII, distribuído em 8 artigos, afastava-se daquele duplo conteúdo, para adotar os princípios constitucionais da organização das Províncias" (HORTA, Raul Machado. Direito Constitucional. 5. ed. Belo Horizonte: Del Rey, 2010. p. 25).

340 HORBACH, Carlos Bastide. Teoria das nulidades do ato administrativo. 2. ed. São Paulo: RT, 2010. p.203.

341 "Desse modo, na apreciação das causas do contencioso administrativo, o Conselho de Estado, nas palavras do Conselheiro Ribas, imitava o direito privado" (HORBACH, Carlos Bastide. Teoria das nulidades do ato administrativo. 2. ed. São Paulo: RT, 2010. p.202). 
No período republicano, sob a égide da Constituição de 24 de fevereiro de $1891^{342}$, com o rompimento da forma unitária de estado e do sistema monárquico de governo, já que se instalava a república federalista e presidencialista, aboliu-se o Conselho de Estado e o contencioso administrativo; neste momento o Direito Administrativo passa a sofrer influência norte-americana, sobretudo em vista da jurisdição una e do controle de constitucionalidade das leis.

No que concerne à teoria das ilegalidades do ato administrativo, com a proclamação da República e o novo contorno do Estado, Carlos Bastide Horbach ${ }^{343}$ assim se manifesta:

Dessa forma, o direito administrativo brasileiro passa a apresentar uma característica peculiar: ao mesmo tempo em que continua a pautar suas construções com base na predominante tradição francesa, formada num substrato político-jurídico completamente diverso, a aplicação dessas construções, desses institutos, é feita num regime norte-americano, presidencialista, federativo e de jurisdição una. A confluência desses dois vetores pode ser o traço de identidade do direito administrativo no Brasil.

E prossegue o autor ${ }^{344}$ :

A influência norte-americana na questão das nulidades do ato administrativo veio, por sua vez, da importação do controle de constitucionalidade das leis, com suas conclusões radicais quanto aos efeitos dos atos legislativos inconstitucionais, que desde Marshall são considerados nulos e írritos, na tradução consagrada por Rui Barbosa. Assim, fazendo um paralelo entre os binômios constituição/lei e lei/ato administrativo, natural a extensão dos efeitos da contrariedade das leis em face da Constituição aos efeitos da contrariedade do ato administrativo diante da lei.

No entanto, alerta Carlos Bastide Horbach ${ }^{345}$ que, mesmo com a influência norteamericana, os primeiros administrativistas da República ainda tratavam a matéria das ilegalidades do ato administrativo, com base da teoria de Direito Civil, mesmo que, em sua opinião, referida teoria perdesse sua força no decorrer da respectiva evolução, durante os séculos XIX e XX.

\footnotetext{
342 “A Constituição de 24 de fevereiro de 1891, fruto do Congresso Constituinte de 1890/1891, rompeu com a forma monárquica de Governo, a forma unitária de Estado e o sistema parlamentar de Governo, para instaurar a República, o Federalismo e o Presidencialismo, formas política sob as quais vivemos" (HORTA, Raul Machado. Direito Constitucional. 5. ed. Belo Horizonte: Del Rey, 2010. p. 26).

343 HORBACH, Carlos Bastide. Teoria das nulidades do ato administrativo. 2. ed. São Paulo: RT, 2010. p.204.

344 HORBACH, Carlos Bastide. Teoria das nulidades do ato administrativo. 2. ed. São Paulo: RT, 2010. p.204. 
Diversos administrativistas da época republicana ${ }^{346}$ registraram suas preocupações com a questão atinente às ilegalidades no âmbito do Direito Administrativo, sendo que, sem nos aprofundarmos no estudo particular de cada uma das doutrinas desenvolvidas, parece-nos merecer destaque os estudos de Ruy Cirne $\operatorname{Lima}^{347}$ e de seus adeptos no que tange à aplicação da teoria das ilegalidades dos atos jurídicos do Direito Privado para o Direito Administrativo, bem como a análise a que procedeu Miguel Seabra Fagundes ${ }^{348}$, que rechaça a transposição das teorias.

Sobre esse ponto, vale registrar as observações de Carlos Bastide ${ }^{349}$ que lembra: “Oswaldo Aranha Bandeira de Mello, seguindo linha de Cirne Lima, Tito Prates e Marsagão, considera que, na falta de texto legal específico para as hipóteses de nulidade e de anulabilidade no direito administrativo, o correto seria aplicar o texto do Código Civil; [...]". Referidos autores são favoráveis à aplicação da teoria das ilegalidades do ato jurídico do Direito Civil no contexto administrativo, logicamente com as peculiaridades próprias a cada doutrina.

$\mathrm{O}$ autor $^{350}$, porém, recorda o entendimento perfilhado por Seabra Fagundes, que não aceitava a clássica distinção entre atos nulos e anuláveis da doutrina de Direito Civil como passível de transposição para o âmbito do Direito Administrativo. Assevera, pois, que "Talvez o traço mais importante da obra de Seabra Fagundes seja a rejeição, no âmbito do direito administrativo, da distinção consagrada no Código Civil entre nulidades e anulabilidades". No entanto, é de se ressaltar que Seabra Fagundes acolhia a possibilidade de adaptação da teoria das ilegalidades do ato jurídico no Direito Privado para o Direito Administrativo, na medida em que, como já ressaltado, observavam-se os princípios e as regras de incidência própria e aos quais deveria se subsumir o Direito Administrativo.

Destarte, a evolução da teoria dos vícios no Direito Administrativo foi contemplada com a influência tanto do Direito Privado, no que toca à classificação dos diversos tipos de vícios ou ilegalidades, catalogando-se os atos, em um prisma inicial, em nulos e anuláveis, como, também, ingerência da doutrina administrativa, oriunda das decisões

\footnotetext{
346 Cite-se Alcides Cruz, Porto Carreiro, Ruy Cirne Lima, Tito Prates da Fonseca, Djacir Menezes, Miguel Seabra Fagundes, Mário Massagão, Oswaldo Aranha Bandeira de Mello, entre outros. Vide: HORBACH, Carlos Bastide. Teoria das nulidades do ato administrativo. 2. ed. São Paulo: RT, 2010. p. 203- 213.

347 LIMA, Ruy Cirne. Princípios de direito administrativo. 6. ed. São Paulo: RT, 1987.

348 FAGUNDES, Miguel Seabra. O controle dos atos administrativos pelo Poder Judiciário. Rio de Janeiro: Freitas Bastos, 1941.

349 HORBACH, Carlos Bastide. Teoria das nulidades do ato administrativo. 2. ed. São Paulo: RT, 2010. p.211. 
do Conselho de Estado francês. Identifica-se aí, sobretudo, uma adaptação dos conceitos extraídos da teoria de Direito Privado para a estrutura do ato administrativo. Não se pode olvidar, porém, a influência norte-americana na seara dos efeitos das ilegalidades, advinda da doutrina da inconstitucionalidade das leis e, no âmbito do Direito Administrativo, realizando uma ponte para a análise entre ato administrativo e lei, avançando este exame para abranger a modulação dos efeitos da eventual declaração de ilegalidade do ato administrativo.

\subsection{NOÇÕES ATUAIS SOBRE A TEORIA DOS VÍCIOS NO DIREITO ADMINISTRATIVO}

Para a abordagem dos aspectos atuais e relevantes em sede de teoria dos vícios no Direito Administrativo não há como deixar de colacionar as disposições da Lei de Ação Popular, Lei Federal n ${ }^{\circ} 4.717$, de 29 de junho de $1965^{351}$, texto que prevê os casos de nulidade e anulabilidade dos atos administrativos lesivos ao patrimônio público. $\mathrm{O}$ artigo $2^{\circ}$ do referido diploma arrola as hipóteses de nulidade, in verbis: "Art. $2^{\circ}$ São nulos os atos lesivos ao patrimônio das entidades mencionadas no artigo anterior, nos casos de: a) incompetência; b) vício de forma; c) ilegalidade do objeto; d) inexistência dos motivos; e) desvio de finalidade".

E mais, o parágrafo único, do aludido artigo $2^{\circ}$, da Lei 4.717/65, desmistifica a forma como irá se consumar a nulidade preconizada, oferecendo as diretrizes para a conceituação das hipóteses de nulidade e indigita:

a) a incompetência fica caracterizada quando o ato não se incluir nas atribuições legais do agente que o praticou; b) o vício de forma consiste na omissão ou na observância incompleta ou irregular de formalidades indispensáveis à existência ou seriedade do ato; c) a ilegalidade do objeto ocorre quando o resultado do ato importa em violação de lei, regulamento ou outro ato normativo; d) a inexistência dos motivos se verifica quando a matéria de fato ou de direito, em que se fundamenta o ato, é materialmente inexistente ou juridicamente inadequada ao resultado obtido; e) o desvio de finalidade se verifica quando o agente pratica o ato visando a fim diverso daquele previsto, explícita ou implicitamente, na regra de competência (Parágrafo único do art. $2^{\circ}$ ).

Prosseguindo, o artigo $3^{\circ}$ do referido texto fixa as hipóteses de anulabilidade do ato administrativo, isto é, aqueles casos que não se enquadram como nulos, determinando:

351 Fonte para pesquisa: <http://www.planalto.gov.br/ccivil_03/leis/L4717.htm>. 
“Art. $3^{\circ}$ Os atos lesivos ao patrimônio das pessoas de direito público ou privado, ou das entidades mencionadas no art. $1^{\circ}$, cujos vícios não se compreendam nas especificações do artigo anterior, serão anuláveis, segundo as prescrições legais, enquanto compatíveis com a natureza deles".

Em verdade, não há discordância ou discrepância de entendimento doutrinário no que tange à imposição de se recompor a legalidade lesada, como se deduz dos diversos textos de Direito Administrativo. Com efeito, considerando que a ideia da ilegalidade do ato administrativo decorre e está intimamente ligada à noção do Estado de Direito, resultando da afronta ao princípio da legalidade - juridicidade - preestabelecido, não há como pensar na manutenção de um ato administrativo que ofenda o ordenamento jurídico sob qualquer fundamento, pois caso assim se procedesse, certamente, estaríamos diante de outro modelo de Estado, muito distante da concepção do Estado de Direito.

Em contrapartida a este consenso da doutrina, com referência ao dever da Administração de recompor a legalidade, mesmo com a referência da Lei de Ação Popular $n^{\circ}$ 4.717/65, e no tocante aos conceitos de nulidade e de anulabilidade dos atos administrativos, a literatura pátria não aborda de forma uníssona a classificação das hipóteses dos vícios dos atos administrativos.

Destarte, o que se conclui da afirmativa acima exposta, é que, não obstante a existência da Lei de Ação Popular e a categoria das nulidades dos atos administrativos por ela abarcados, insuficiente se oferece a sistematização do espectro das ilegalidades em sede de Direito Administrativo. Ressente-se a ausência de outras leis em sentido estrito, oriundas do Poder Legislativo, que sistematizem os casos de anulação em decorrência de ilegalidade do ato administrativo, de uma forma completa e específica. Isso apesar de reconhecer o valor das Leis processuais - a do Processo Administrativo Federal no 9.784/99 e a Lei do Processo Administrativo no âmbito do estado de São Paulo no 10.177/98 - bem como das Súmulas 473 e 346, ambas do Supremo Tribunal Federal. Emerge daí, para a doutrina e a jurisprudência, um campo com margens mais livres de abordagem do tema, isto é, os vícios do ato administrativo, o que dá ensejo à construção de conceitos que, por muitas vezes, não seguem as mesmas premissas comparativas, ou melhor, as mesmas linhas de raciocínio.

Assim é que, por força das doutrinas de Direito Administrativo ${ }^{352}$ e com base na análise jurisprudencial, poder-se-ia indicar como espécies de atos viciados: o ato nulo, o ato

352 BANDEIRA DE MELlo, Celso Antônio. Curso de Direito Administrativo. 29. ed. São Paulo: Malheiros, 2012. p. 474 e seguintes; MEIRELLES, Hely Lopes. Direito Administrativo Brasileiro. 33. ed. São Paulo:RT, 2007. p. 174 e seguintes; ARAÚJO, Edmir Netto de. Curso de Direito Administrativo. 5. ed. revisada e atualizada. São Paulo: Saraiva, 2010. p. 493 e seguintes; DI PIETRO, Maria Sylvia Zanella. Direito Administrativo. 25. ed. São Paulo: Atlas, 2012. p. 245 e seguintes. 
anulável, o ato irregular e o ato inexistente. Resta-nos registrar, por mais desta vez, que o debate quanto ao tratamento conferido pela doutrina pátria não se dá de forma uníssona.

Relevante, contudo, apontar desde já que, entre nós, a doutrina efetua uma distinção entre ato nulo e o anulável, com base, principalmente, na gravidade do defeito e na possibilidade de recuperação do ato viciado, sendo importante não olvidarmos do tratamento que, no Direito Privado, se oferece aos atos jurídicos e à influência deste segmento do Direito em relação ao Direito Administrativo.

Hely Lopes Meirelles sustenta que qualquer ilegalidade que acometa o ato administrativo é suficiente para a sua declaração de nulidade; repele a possibilidade de existência de atos anuláveis, bem como a transposição da teoria das ilegalidades do ato jurídico do Direito Civil para o Direito Administrativo. Admite, no entanto, a convalidação em certos casos. No dizer de Alexandre Mazza ${ }^{353}$, é a chamada "teoria unitária" das ilegalidades, bastante criticada, tendo em vista que a própria Lei 9784/99, em seu artigo 55, prevê casos onde a Administração pode convalidar certos vícios. Evidente ressalva, pois, a existência de, no mínimo, atos nulos e anuláveis, apresentando-se estes últimos passíveis de convalidação, pelo que a teoria de Hely Lopes Meirelles não parece se coadunar com este espírito legislativo.

De toda forma, vejamos os ensinamentos de Hely Lopes Meirelles ${ }^{354}$, no que tange ao dilema:

[...] Duas observações ainda se impõem em tema de invalidação de ato administrativo: a primeira é a de que os efeitos do anulamento são idênticos para os atos nulos como para os chamados atos inexistentes; a segunda é a de que em Direito Público não há lugar para os atos anuláveis, como já assinalamos precedentemente. Isto porque a nulidade (absoluta) e a anulabilidade (relativa) assentam, respectivamente, na ocorrência do interesse público e do interesse privado na manutenção ou eliminação do ato irregular. [...] O ato administrativo é legal ou ilegal; é valido ou inválido. Jamais poderá ser legal ou meio legal; válido ou meio-válido, como ocorreria se se admitisse a nulidade relativa ou anulabilidade, como pretendem alguns autores que transplantam teorias do Direito Privado para o Direito Público sem meditar na sua adequação aos princípios específicos da atividade estatal. Pode, como vimos, haver a convalidação, desde que não haja lesão ao interesse público nem prejuízos a terceiros. Pode haver também a correção de mera irregularidade que não torna o ato nem nulo nem anulável, mas simplesmente defeituoso ou ineficaz até sua retificação.

\footnotetext{
353 MAZZA, Alexandre. Manual de Direito Administrativo. 2. ed. São Paulo: RT: 2012. p. 209.

354 MEIRELLES, Hely Lopes. Direito Administrativo Brasileiro. 33. ed. São Paulo: RT, 2007. p. 206-207.
} 
Outra das teorias envolvendo a ilegalidade do ato administrativo é a conhecida como "binária" 355 , defendida por juristas de escol, a exemplo de Oswaldo Aranha Bandeira de Mello e Tito Prates da Fonseca, entre outros. Defendem estes a aplicação da doutrina das ilegalidades do ato jurídico desenvolvida no Direito Civil também para o Direito Administrativo. Ponderam que há dois tipos de vícios, aqueles que acarretam a nulidade e aqueles que importam a anulabilidade. A crítica que se faz a essa teoria, em nossa visão, é o excesso de esforço de analogia para a transposição para o Direito Administrativo, sendo que deve ser reconhecida uma distância considerável entre esses segmentos do Direito, haja vista a preponderância dos interesses que os informam. De fato, no Direito Privado, prevalece a autonomia da vontade das partes enquanto no Direito Administrativo o comando é da supremacia do interesse coletivo e da finalidade pública.

Vejamos o entendimento de Oswaldo Aranha Bandeira de Mello ${ }^{356}$ :

[...] Será nulo quanto à capacidade da pessoa se praticado o ato por pessoa jurídica sem atribuição, por órgão absolutamente incompetente, ou por agente usurpador da função pública. Será nulo quanto ao objeto, se ilícito ou impossível, por ofensa frontal à lei, ou nele se verifique o exercício de direito de modo abusivo. Será nulo, ainda, se deixar de respeitar forma externa prescrita em lei ou preterir solenidade essencial para sua validade. Ao contrário, será simplesmente anulável, quanto à capacidade da pessoa, se praticado por agente incompetente, dentro do mesmo órgão especializado, uma vez o ato cabia, na hierarquia, ao superior. Outrossim, será tão somente anulável o que padeça de vício de vontade decorrente de erro, dolo, coação moral ou simulação.

A denominada teoria "ternária",357 das ilegalidades dos atos administrativos, cujo expoente de maior expressão é Miguel Seabra Fagundes, inclui, dentre os atos nulos e anuláveis, os atos irregulares, portadores de vícios que, por serem irrelevantes e superficiais, não chegam a causar abalo na ordem jurídica do ato administrativo. Seabra Fagundes, como já ressaltado, entende que o transporte da teoria das ilegalidades do ato jurídico do Direito Privado para o Direito Administrativo não é cabível. Aceita, no entanto, o jurista, a possibilidade de adaptação às peculiaridades da doutrina de direito administrativo, quais sejam - na lição do administrativista - os princípios condutores da finalidade e do interesse público, bem como o axioma da legalidade, fortemente vinculados ao ato administrativo.

355 Conforme noção elencada por: MAZZA, Alexandre. Manual de Direito Administrativo. 2. ed. São Paulo: RT: 2012. p. 210.

356 BANDEIRA DE MELlo, Oswaldo Aranha. Princípios Gerais de Direito Administrativo. Vol. I. 1. ed. Rio de Janeiro: Forense, 1979. p. 579.

357 Conforme noção elencada por: MAZZA, Alexandre. Manual de Direito Administrativo. 2. ed. São Paulo: RT: 2012. p. 210. 
Referida tese, embora mais avançada na esfera do Direito Administrativo, deixa de elencar como vício o ato inexistente. Ainda não é a teoria que adotamos.

Seabra Fagundes ${ }^{358}$, assim se manifesta: "Quanto à maior ou menor importância dos defeitos dos atos administrativos, parece-nos que se pode dividi-los, atendendo mais aos princípios gerias do Direito Administrativo que aos textos das leis civis, em duas categorias: vícios que determinam a invalidez e vícios que não a determinam. No primeiro caso, a grave repercussão do vício sobre o ato, torna-o incapaz de subsistir. $\mathrm{O}$ ato só pode ser invalidado ou nulo. No segundo, o vício pode ser grave, mas razões especiais aconselham a subsistência do ato (como nos casos de incompetência por falta de requisitos à investidura), e pode ser de secundária importância, não justificando, por isso, a fulminação do ato (como nos pequenos defeitos de forma). O ato será apenas irregular".

Justificando referida discrepância de entendimentos, invoca-se o magistério de Celso Antônio Bandeira de Mello ${ }^{359}$, anotando a teoria das ilegalidades no Direito Administrativo: "A ausência de leis administrativas que sistematizem casos de invalidade e seus efeitos propiciou que surgissem três diferentes posições quanto aos atos inválidos no Direito Administrativo brasileiro". O autor ${ }^{360}$, assim, identifica como atos inválidos os nulos, anuláveis e os inexistentes. E mais, indica os atos irregulares não como inválidos, mas como atos que possuem vícios irrelevantes.

Nesse ponto, permitimo-nos discordar do registro produzido por Bandeira de Mello, uma vez que a irregularidade verificada no ato administrativo, em sede de Direito Administrativo, qualifica-se como vício que ataca o plano de validade do referido ato, ainda que de ínfima monta. Ora, uma Administração pautada pelos axiomas da legalidade não pode deixar de sanar este campo na perspectiva do interesse coletivo, mormente atendendo o modelo de Estado de Direito que exige o reparo de qualquer irregularidade que se apresenta no ato administrativo, seja de que tamanho for.

Apresenta, outrossim, Celso Antônio Bandeira de Mello ${ }^{361}$, as três diferentes posições com relação aos atos ilegais no Direito Administrativo, a saber:

\footnotetext{
358 FAGUNDES, Miguel Seabra. O controle dos atos administrativos pelo Poder Judiciário. Rio de Janeiro: Freitas Bastos, 1941.p. 51.

359 BANDEIRA DE MELlo, Celso Antônio. Curso de Direito Administrativo. 29. ed. São Paulo: Malheiros, 2012. p. 475.

360 BANDEIRA DE MELlo, Celso Antônio. Curso de Direito Administrativo. 29. ed. São Paulo: Malheiros, 2012. p. 475.

361 BANDEIRA DE MELlo, Celso Antônio. Curso de Direito Administrativo. 29. ed. São Paulo: Malheiros, 2012. p. 475.
} 
A) Alguns entendem que o vício acarreta sempre a nulidade do ato. É a posição de Hely Lopes Meirelles, por exemplo. B) Outros, como Tito Prates da Fonseca e Oswaldo Aranha Bandeira de Mello, sustentam que a tradicional distinção entre atos nulos e anuláveis aplica-se ao Direito Administrativo. De acordo com este último autor, as espécies mencionadas se contrapõem em que: a) os atos nulos não são convalidáveis, ao passo que os anuláveis o são. Vale dizer: conhecido o vício, há maneiras de corrigi-lo retroativamente; b) os atos nulos, em juízo, podem ser fulminados sob provocação do Ministério Público quando the caiba intervir no feito, ou ex officio pelo juiz, ao passo que os anuláveis dependem desta arguição pelos interessados para serem fulmináveis; c) os atos nulos só prescrevem longis temporis, enquanto os anuláveis prescrevem brevi temporis. C) Seabra Fagundes defende uma visão tricotômica: nulos, anuláveis e irregulares; ressalvando, todavia, que as duas primeiras espécies não correspondem às do Código Civil, nem quanto aos tipos de vícios nem quanto aos efeitos deles. Todos negam relevância jurídica à espécie atos inexistentes, indicando que, de direito, equivalem aos atos nulos.

Por fim, assim define Celso Antônio Bandeira de Mello ${ }^{362}$, os atos viciados no Direito Administrativo:

[...] dir-se-ão inexistentes os atos que assistem no campo do impossível jurídico, como tal entendida a esfera abrangente dos comportamentos que o Direito radicalmente inadmite, isto é, dos crimes que atentem contra a dignidade humana, [...] valendo como exemplo as hipóteses já referidas, de "instruções" baixadas por autoridade policial para que subordinados torturem presos, autorizações para que agentes administrativos saqueiem estabelecimentos dos devedores do Fisco ou para que alguém explore trabalho escravo etc; [...] nulos: a) os atos que a lei assim o declare; b) os atos em que é racionalmente impossível a convalidação, pois, se o mesmo conteúdo (é dizer, o mesmo ato) fosse novamente produzido, seria reproduzida a invalidade anterior; [...] anuláveis: a) os atos que a lei assim os declare; b) os que podem ser repraticados sem vício. [...]"(grifos nossos).

Para o panorama administrativo, importante se oferece a definição de Edmir Netto de Araújo de ato viciado e ato inexistente. $\mathrm{O}$ mestre efetua relevante distinção no que tange aos vícios que incidem no plano da validade do ato administrativo, indigitando que essas lesões podem importar em nulidade, anulabilidade e mera irregularidade; isto a par de admitir a importância jurídica do ato inexistente, que ataca os elementos estruturais do ato administrativo, no plano da existência. Essa é a teoria dos vícios dos atos administrativos que adotamos na presente dissertação.

Pois bem, assim se manifesta o administrativista ${ }^{363}$ :

362 BANDEIRA DE MELlo, Celso Antônio. Curso de Direito Administrativo. 29. ed. São Paulo: Malheiros, 2012. p. 486.

363 ARAÚJO, Edmir Netto de. Curso de Direito Administrativo. 5. ed. revisada e atualizada. São Paulo: Saraiva, 2010. p. 494. 
[...] Ato viciado é, portanto, o ato defeituoso ou imperfeito que não contém ou não percorreu todos os estágios de existência e validade preceituados pelo ordenamento, podendo tais defeitos atingi-lo nos elementos estruturais ou nos requisitos de validade, e assim, causar sua retirada (invalidade) do mundo jurídico, quer por declarar-se sua nulidade absoluta, quer por anularse o ato anulável, ou, ainda, por caracterizá-lo como inexistente. [...] Ato inexistente é caracterizado pela ausência de elementos essenciais de existência, como no caso do usurpador de função pública (falta o agente público). [...] Invalidade é palavra genérica que se refere ao estudo dos atos absolutamente inválidos (atos nulos), dos atos relativamente inválidos (atos anuláveis) ou simplesmente irregulares, com defeitos de pequena monta que geralmente não obrigam à invalidação.

De outra perspectiva, elencando as características de perfeição e eficácia do ato administrativo, Edmir Netto de Araújo ${ }^{364}$ relata:

Atos administrativos existentes e válidos (perfeitos), e, além disso, eficazes, são aqueles que a partir de interesse público concretamente existente (motivo), caminham "incólumes" por todos os estágios de sua formação (pressupostos, agente, declaração de vontade, objeto, conteúdo, forma e fatores de eficácia), da maneira prescrita ou admitida pelo ordenamento jurídico para a produção dos efeitos jurídicos específicos desejados, atingindo assim sua finalidade de interesse público, simétrica ao motivo. A antítese da normalidade jurídica citada é representada pelos atos administrativos viciados que, em razão de certos defeitos ocorridos em sua estrutura ou formação, poderão ser inexistentes, imperfeitos ou ineficazes.

Verificada a evolução das doutrinas que cuidam dos vícios dos atos administrativos, o foco passa para o exame da ocorrência de fatores lesivos em contexto processual, bem como sobre os respectivos e eventuais efeitos de uma declaração de ilegalidade do ato administrativo no contexto do processo administrativo. Alocaremos para tanto a análise dos efeitos da incidência dos vícios aqui elencados, no espectro processual, com olhar atencioso sobre a nulidade do ato administrativo processual.

\subsection{TRATAMENTO DOS VÍCIOS NO PROCESSO ADMINISTRATIVO}

Diagnóstico similar ao detectado no campo do estudo da teoria dos vícios do ato administrativo pode ser transposto para a seara do processo administrativo. Isso se deve ao fato da ausência de legislação própria e específica que regule de que forma o ato

364 ARAÚJO, Edmir Netto de. Curso de Direito Administrativo. 5. ed. revisada e atualizada. São Paulo: Saraiva, 2010. p. 493-494. 
administrativo processual será tocado pela ilegalidade, nem como esse mesmo ato poderá ser retirado do mundo jurídico, regulando-se, concomitantemente, os efeitos que possam decorrer da manifestação dos vícios incidentes sobre o ato administrativo processual.

A legislação atual, referente aos vícios no Direito Administrativo, em âmbito federal (a Lei de Ação Popular n 4.717/65 e Lei de Processo Administrativo Federal $n^{\circ}$ 9.784/99), dispõe sobre as ilegalidades do ato administrativo, em um contexto, por vezes, isolado do processo administrativo, sendo importante ressaltar que, no momento em que nos deparamos com o processo administrativo, o ato administrativo perde a importância pontual, para se posicionar em clima de uma coletividade de atos administrativos, ligados e interdependentes entre si, preparatórios de uma decisão final.

Essa constatação referente ao conjunto de atos administrativos nos remete ao próprio conceito de processo administrativo, já enunciado na presente dissertação, valendo lembrar a noção de processo administrativo acolhida por Edmir Netto de Araújo ${ }^{365}$, inspirando-se na doutrina italiana que se refere a provimento. Registra o autor: "[...] como todo ato estatal de autoridade, como a lei, o regulamento, o ato administrativo e a sentença, para o qual concorre uma série de atos preparatórios que constitutem o procedimento”. E, prossegue:

[...] no Direito Administrativo italiano, "provvedimento" significa, frequentemente, "atto amministrativo" especialmente se envolve decisão do agente. O provimento praticado pelo Estado, nesse raciocínio, pode resultar de um procedimento simples, apenas formalizando passos em direção ao objetivo visado; ou então, estruturado em forma contraditória, para permitir decisão sobre interesses antagônicos e resistidos, caso em que teremos o processo. Esta é a nossa posição.

Trazendo um recorte para análise dos vícios do ato administrativo processual, Sergio Ferraz e Adilson Abreu Dallari ${ }^{366}$, assim se manifestam:

[...] ao contrário de vários outros diplomas análogos (que cuidam, a um só tempo, do ato e do processo administrativo), a Lei no 9784 , de 1999, regula estritamente o processo (e o procedimento pertinente) administrativo. Mas não aqui, em seu Capítulo XIV, arts. 53 a 55: a matéria aí regulada é essencialmente a do ato administrativo em geral, por isso mesmo atingindo o processo administrativo reflexamente. Mas reflexamente apenas; e, por isso mesmo, nos aludidos arts. 53 a 55 iremos encontrar prescrições que nada dizem referentemente ao processo em sentido próprio.

\footnotetext{
365 ARAÚJO, Edmir Netto de. Curso de Direito Administrativo. 5. ed. São Paulo: Saraiva, 2010. p. 917. 
Vale lembrar que a Lei $\mathrm{n}^{\mathrm{o}} 10.177 / 98$, que disciplina o processo administrativo no âmbito do Estado de São Paulo, também não faz referência de forma autônoma aos vícios do ato administrativo processual, aludindo, por vezes, ao ato administrativo em um contexto singular, e, outras, ao ato processual. A seu turno, a Lei $n^{\circ} 14.141 / 2006$, reguladora do processo administrativo no Município de São Paulo, utiliza a mesma técnica, deixando de trazer uma definição exclusiva para os vícios do ato administrativo processual.

Depreende-se, portanto, que a análise dos vícios no que concerne ao ato administrativo em um contexto isolado poderá ser transferida, em certa medida, para o ato administrativo processual. Isso porque, certamente, a investigação que deve ser realizada sobre a legalidade dos trâmites de determinado processo administrativo engloba tanto a análise pontual de cada ato administrativo processual, ao longo da tramitação do processo, bem como, em uma perspectiva panorâmica, um olhar sobre todo o seu percurso, após o seu encerramento com uma decisão administrativa irrecorrível. Nada obsta, porém, que ambas as investigações sejam realizadas de forma simultânea.

Nesse diapasão, revela-se de importância registrar que o ato processual administrativo não só deve vincular-se aos critérios de legalidade, impondo a observância dos tópicos que tratam dos vícios no Direito Administrativo, isto é, aquelas regras que apontam as ilegalidades que podem atingir os elementos de existência e os requisitos de validade do ato administrativo, como também deve atendimento aos princípios de Direito Administrativo, notadamente àqueles de regência do processo administrativo.

No que concerne às ilegalidades que atingem os elementos de existência e os requisitos de validade do ato administrativo, a investigação da normalidade do ato administrativo processual deverá ser efetuada diante dos planos de existência e de validade. Isto é, deve-se proceder a uma análise prévia e elementar, questionando se o ato processual observou na sua trajetória todos os elementos básicos para sua constituição, dentre eles, no caso do ato administrativo, a forma, o conteúdo, o objeto, o agente público, o tempo e o lugar. Encontrando-se esses elementos devidamente respeitados, sem incidência de ilegalidades, certamente o ato existirá. Em seguida, o estudo deve ser direcionado ao plano da validade do ato administrativo, procedendo-se a análise da legalidade, dos denominados requisitos do ato administrativo processual, isto é, competência, forma, motivo, objeto e finalidade.

Pois bem, diante do cenário que reclama a análise da legalidade do ato administrativo processual, não podemos perder de vista a exigência de vinculação aos princípios do Direito Administrativo, já apontados na presente dissertação. Constituem parâmetros de legalidade a que o ato administrativo processual deve se alinhar todos os 
princípios norteadores da Administração Pública, esculpidos pelo ordenamento jurídico em vigor, que se aplicam ao processo administrativo. A legalidade e a supremacia do interesse público, como axiomas informativos do Direito Administrativo, de sua parte, permeiam toda a atividade administrativa que se expressa por intermédio do processo administrativo.

Nessa linha, os princípios gerais citados no Capítulo I, item 1.4.2 da presente dissertação ${ }^{367}$, terão sua aplicação no processo administrativo, na medida em que este deve se alinhar, tanto às regras que modulam especificamente os procedimentos e os trâmites processuais, como, do mesmo modo, ao Direito que se manifesta, também, através de princípios; competindo, nesse passo, lembrar definição já exposta, que esclarece constituírem os princípios: "fundamento das regras; normas qualitativamente distintas e que integram valores".

Cumpre apontar, sobretudo, a incidência dos axiomas específicos que norteiam o processo administrativo, quais sejam o contraditório, a ampla defesa, a duração razoável do processo, a oficialidade, a verdade material e o informalismo ou obediência às formas e procedimentos, todos tratados no item 1.5, do Capítulo I, desta dissertação. E, demais disso, não poderíamos deixar de mencionar o princípio do devido processo legal. Esses cânones diretores do processo administrativo devem ocupar posição preponderante na análise da legalidade dos atos administrativos processuais e do processo administrativo em geral. Impõem respeito na íntegra de seus valores, exigindo-se sua aplicação ao longo dos trâmites processuais no âmbito da Administração.

Outra questão de relevo diz respeito aos parâmetros de legalidade para suprir a ausência de norma a regular as consequências da constatação dos vícios no âmbito do processo administrativo. Parece não restar dúvida de que a teoria dos vícios do ato administrativo, oriunda da doutrina de Direito Privado e transplantada para o Direito Administrativo, com suas respectivas peculiaridades, deve incidir, de modo reflexo, sobre os atos administrativos processuais. Certo é, também, nesta esteira, que os princípios do Direito Administrativo e os peculiares ao processo administrativo não podem ser violados pelos atos administrativos processuais. Questiona-se, no entanto, se os princípios e as regras envolvendo

\footnotetext{
367 Arrolamos no item 1.4.2, do Capítulo I, os seguintes princípios do Direito Administrativo: (1.4.2.1) Princípio da indisponibilidade do interesse público; (1.4.2.2) Princípio do poder-dever; (1.4.2.3) Princípio da igualdade - isonomia; (1.4.2.4) Princípio da impessoalidade; (1.4.2.5) Princípio da moralidade administrativa; (1.4.2.6) Princípio da publicidade; (1.4.2.7) Princípio da eficiência; ( 1.4.2.8) Princípio da razoabilidade e proporcionalidade; (1.4.2.9) Princípio da responsabilidade do Estado; (1.4.2.10) Presunção de legitimidade, imperatividade e autoexecutoriedade; (1.4.2.11) Princípio do controle jurisdicional; (1.4.2.12) Princípio da autotutela; (1.4.2.13) Princípio da discricionariedade.
} 
a declaração de ilegalidade do ato processual previstos no Direito Civil e Penal, podem ser, também, utilizados no âmbito do processo administrativo.

Para o exame desta problemática, é mister que sejam indicados, brevemente, os princípios a que se pretende referir. E, para tanto, elucidativa a lição de Cintra, Grinover e Dinamarco, quando abordam a Teoria Geral do Processo, elencando os princípios da causalidade, da instrumentalidade das formas, do interesse e da economia processual. Instigante a manifestação dos doutrinadores processualistas ${ }^{368}$ :

[...] A anulação do ato processual, nos casos de vícios indicados no parágrafo anterior, obedece a uma série de regras, contidas na lei ou impostas pelos princípios gerais, e que em muito contribuem a dar uma feição realista à teoria da nulidade e ao próprio sistema da legalidade das formas processuais. Tais regras contêm-se nos princípios: a) da causalidade; b) da instrumentalidade das formas; c) do interesse; d) da economia processual.

O princípio da causalidade ${ }^{369}$, com previsão expressa na primeira parte do artigo 248, do Código de Processo Civil, reza que a ilegalidade de um ato processual contamina os posteriores dependentes do referido ato, anulando-se o processo a partir da declaração do vício daquele ato processual. $\mathrm{O}$ princípio da instrumentalidade das formas ${ }^{370}$, presente no Código de Processo Penal, no artigo 563, e no Código de Processo Civil, no $\S 1^{\circ}$, do artigo 249, bem como em várias outras disposições das citadas leis processuais, consiste na declaração da ilegalidade do ato processual somente caso o objetivo não tiver sido atingido, invocando-se o brocardo oriundo do direito francês pas de nullité sans grief.

O princípio do interesse ${ }^{371}$, presente no artigo 243 do Código de Processo Civil, e no artigo 565 do Código de Processo Penal, preconiza que a parte que der causa à ilegalidade do ato processual não poderá se beneficiar da declaração da ilegalidade do mesmo ato.

\footnotetext{
368 CINTRA, Antônio Carlos de Araújo; GRINOVER, Ada Pellegrini; DINAMARCO, Cândido R. Teoria Geral do Processo. 27. ed. São Paulo: Malheiros, 2011. p.372.

369 "Essa regra sofre alguns temperamentos, por força de outros princípios coexistentes com ela: a) a nulidade de uma parte do ato não prejudicará as outras, que dela sejam independentes $(i b$.$) ; b) podendo repetir-$ se $o$ ato irregular, não se anula todo o processo (e isso acontece quando os atos posteriores não são dependentes do ato nulo)" (CINTRA, Antônio Carlos de Araújo; GRINOVER, Ada Pellegrini; DINAMARCO, Cândido R. . Teoria Geral do Processo. 27. ed. São Paulo: Malheiros, 2011. p.372).

370 “[...] estatuindo a lei que a consecução do objetivo visado pela determinação da forma processual faz com que o ato seja válido ainda se praticado contra a exigência legal (CPC, art. 244). No processo penal nota-se a tendência a presumir o prejuízo, sempre que a omissão interfira com o direito de defesa" (CINTRA, Antônio Carlos de Araújo; GRINOVER, Ada Pellegrini; DINAMARCO, Cândido R. Teoria Geral do Processo. 27. ed. São Paulo: Malheiros, 2011. p.372).
}

371 “[...] Essa restrição, contudo, só tem aplicação nas hipóteses de nulidade relativa, quando a exigência de determinada forma é instituída no interesse das partes e não da ordem pública; aí, e não na nulidade absoluta, é razoável que o legislador deixe exclusivamente a critério da parte prejudicada a provocação da decretação de 
Do seu lado, o princípio da economia processual, contido no Código de Processo Civil, artigos 248 (primeira e segunda parte), 250 e 113, §2 $2^{\circ}$, bem como no Código de Processo Penal, artigo 567, mantém relacionamento com o princípio da instrumentalidade das formas e possui diversas aplicações no tocante às ilegalidades do ato processual. Neste escaninho situam-se a questão da análise do grau de dependência e da contaminação dos atos processuais para a declaração de ilegalidade dos mesmos, assim como o problema da possibilidade de aproveitamento de alguns atos processuais viciados, dependendo da importância do respectivo ato processual no contexto processual.

Parece-nos razoável que esses princípios norteadores da declaração de ilegalidade dos atos processuais tenham seu campo de aplicação limitado ao Direito Civil e ao Direito Penal quando diante de vícios que, no espectro administrativo, resultem em atos processuais administrativos irregulares ou anuláveis. Neste caso, a aplicação desses princípios no âmbito do processo administrativo pode se dar através da analogia, respeitando-se as peculiaridades, as regras e os princípios do Direito Administrativo, mormente, os princípios da legalidade e da supremacia do interesse público sobre o privado.

No âmbito do Direito Administrativo, já há um instituto que, de certa forma, consagra, atendidas as peculiaridade do Direito Administrativo, a aplicação de alguns desses princípios, norteadores da declaração de ilegalidade dos atos processuais (a exemplo do princípio da instrumentalidade das formas e o da economia processual). Trata-se do instituto da convalidação do ato administrativo, prática própria ao contexto do ato administrativo processual $^{372} 373$, que será ainda objeto de exame.

nulidade [...]. Prende-se também ao princípio do interesse a regra segundo a qual a nulidade não será pronunciada quando o julgamento do mérito for a favor da parte a ser beneficiada pelo seu reconhecimento (CPC, art. 249, §2 $2^{\circ}$ " (CINTRA, Antônio Carlos de Araújo; GRINOVER, Ada Pellegrini; DINAMARCO, Cândido R. Teoria Geral do Processo. 27. ed. São Paulo: Malheiros, 2011. p.373).

372 A título de exemplo, na Lei 9784/99: “Art. 55. Em decisão na qual se evidencie não acarretarem lesão ao interesse público nem prejuízo a terceiros, os atos que apresentarem defeitos sanáveis poderão ser convalidados pela própria Administração". Na Lei 10177/98: “Artigo 10 - A Administração anulará seus atos inválidos, de ofício ou por provocação de pessoa interessada, salvo quando: I - ultrapassado o prazo de 10 (dez) anos contado de sua produção; II - da irregularidade não resultar qualquer prejuízo; III - forem passíveis de convalidação".

373 Para uma noção profunda sobre a convalidação do ato administrativo, ver: ARAÚJO, Edmir Netto de. Convalidação do ato administrativo. São Paulo: Editora Ltr, 1999; ZANCANER, Weida. Da convalidação e da invalidação dos atos administrativos. São Paulo: RT, 1990. 


\subsection{DOS TIPOS DE VÍCIOS NO PROCESSO ADMINISTRATIVO}

Adotando-se a teoria dos vícios do ato administrativo sob a perspectiva de quatro hipóteses, isto é, a inexistência, a irregularidade, a anulabilidade e a nulidade, o enfoque ao ato processual se apresenta, agora, como objetivo, arrolando-se os vícios descritos em um contexto de processo administrativo.

Ressalta-se que a teoria dos vícios do ato administrativo não esgota as possibilidades de previsão de todos os vícios que podem atingir o ato administrativo.

$\mathrm{Na}$ realidade, as regras e os princípios que tratam dos vícios dos atos administrativos não esgotam o elenco dos atos administrativos viciados. Até porque algumas dessas hipóteses se apresentam imprevisíveis. Alem disso, não se pode correr o risco de enunciar taxativamente todas as hipóteses dos atos administrativos atacados pelos vícios, sob pena de mantermos atos administrativos que afrontem a legalidade, mas, que não se subsumem às hipóteses listadas na textura normativa.

Nesses termos, procuraremos abordar os vícios dos atos administrativos processuais, arrolando alguns casos de maior evidência.

\subsubsection{Ato administrativo processual inexistente}

A ausência de elementos essenciais do ato administrativo acarretará a declaração de sua inexistência ${ }^{374}$. Trata-se de conceito diferente de nulidade, anulabilidade e irregularidade, haja vista que a inexistência incide sobre elementos essenciais ao ato administrativo. A respeito, significativo o magistério de Cretella Junior ${ }^{375}$ que aborda a diferença entre o conceito de elementos e de requisitos do ato administrativo, alertando que: “elementos se referem à existência do ato administrativo de maneira estática (agente, objeto e forma) e requisitos, em forma de aperfeiçoamento dinâmico para sua operacionalidade (agente capaz e competente, objeto lícito e possível, forma prescrita ou permitida em lei)".

\footnotetext{
374 Para o estudo profundo sobre a teoria do ato administrativo inexistente, vide: GUALAZZI, Eduardo Lobo Botelho. Ato Administrativo Inexistente. São Paulo: RT, 1980. 
Para Edmir Netto de Araújo ${ }^{376}$, posição que adotamos na presente dissertação, os elementos essenciais do ato administrativo classificam-se em intrínsecos e extrínsecos, sendo os intrínsecos aqueles “[...] que se contêm no interior do próprio ato administrativo [...]” , elencando-se, nesta ordem, “[...] a ação ou abstenção humanas (atos comissivos e omissivos) que tomam alguma forma"; depois "[...] o objeto ou conteúdo, que é a matéria de interesse público, a relação jurídica administrativa sobre o que o ato dispõe; [...]” e, por derradeiro, "[...] a forma que tomam a ação ou abstenção humanas, condicionando-as para obter o resultado objetivado ou admitido, constituindo a declaração de vontade do Estado, assim exteriorizada pelo comportamento de seu agente".

Para o administrativista, os elementos extrínsecos são aqueles 377 “[...] visualizados fora do ato, mas indispensáveis no plano ontológico", sendo "[...] o agente público [...] que em nome do Estado exterioriza sua vontade normativa; [...]" e "o tempo e lugar, sem os quais não há nem mesmo fato jurídico, quanto mais ato jurídico administrativo".

Por sua vez, Junqueira de Azevedo ${ }^{378}$, cujo entendimento é adotado por Edmir Netto de Araújo, assim se manifesta sobre o tema:

[...] sem os elementos intrínsecos e extrínsecos (de existência) é impensável e inexistente o negócio ou o ato jurídico, pois: a) faltando os elementos tempo e lugar, não há nem mesmo fato jurídico; b) sem agente, pode haver fato jurídico, mas não ato ou negócio; c) sem declaração de vontade sobre um objeto, feita de alguma forma, pode até haver fato jurídico, mas não negócio, nem ato jurídico.

A doutrina costuma citar como exemplo de ato administrativo inexistente, vinculado ao elemento referente ao agente público, o caso de usurpador de função pública ${ }^{379}$, quando o agente não é funcionário e emana ato como assim o fosse.

\footnotetext{
376 ARAÚJO, Edmir Netto de. Convalidação do ato administrativo. São Paulo: Editora Ltr, 1999. p. 28.

377 ARAÚJO, Edmir Netto de. Convalidação do ato administrativo. São Paulo: Editora Ltr, 1999. p. 29.

378 AZEVEDO, Antônio Junqueira de. Negócio Jurídico. Existência, validade e eficácia. São Paulo: Saraiva,1986. p.44.

379 Merecem considerações os apontamentos de Edmir Netto de Araújo: “Ato de funcionário demente não é inexistente, enquanto por essa demência não é afastado do serviço público, mas inválido, porque lhe falta o requisito da capacidade (art. 5 do Código Civil Brasileiro) e não elemento, pois ainda seria funcionário, podendo ser até mesmo competente: quando decretada sua insanidade, seria afastado do serviço público. Da mesma forma, no ato emanado de funcionário de ramo diverso da Administração, o defeito é de competência, que é requisito, pois seria funcionário e provavelmente teria capacidade civil para expressar vontade: ainda aqui, o ato seria inválido e não inexistente. Já no caso do usurpador de função, o agente não é funcionário e, portanto, o ato administrativo (possível de ser praticado só por agentes públicos) não existe como ato administrativo. Mas em caso similar, do funcionário de fato, a afirmativa não pode ser tão radical" (ARAÚJO, Edmir Netto de. Convalidação do ato administrativo. São Paulo: Editora Ltr, 1999. p. 73).
} 
Com relação ao elemento objeto e conteúdo do ato administrativo, Weida Zancaner $^{380}$ cita os seguintes exemplos, grafando, ao invés de ato inexistente, atos absolutamente insanáveis, aqueles que têm por objeto a prática de um ato criminoso, isto é, juridicamente impossível, ou ato materialmente impossível, senão vejamos: ordem para que uma autoridade torture um preso; autorização para exploração de trabalho escravo; licença para funcionamento de casa de lenocínio; autorização para prática de eutanásia ou para saquear propriedades de devedores do fisco; no que tange ao ato materialmente impossível, cita a nomeação de pessoa falecida, decreto expropriando um imóvel inexistente.

Transpondo esses registros para o ato administrativo processual, depreende-se que, para a sua existência, este deve manter todos os elementos essenciais concomitantemente, isto é, que todos os elementos básicos para sua formação estejam presentes, entre eles, a forma, o conteúdo ou objeto, o agente público, o tempo e o lugar. E, tão só, diante desses elementos devidamente constituídos, sem incidência de falhas e defeituosidades, intrínseca e extrinsecamente, o ato processual existirá.

Ocorre que, quando nos deparamos com o processo administrativo, surge o desafio de realizar a transposição dos elementos essenciais do ato administrativo comum para o ato administrativo processual. Tal constatação se deve ao fato de que, no processo administrativo, poderemos ter atos administrativos processuais não exarados por agente público, como é o caso dos atos dos sujeitos do processo, bem como há uma forma prefixada pela lei, com fases diferentes e rigorosamente previstas para o andamento processual, considerando, por exemplo, a gravidade da sanção a ser aplicada, como ocorre nos processos administrativos disciplinares.

Destarte, o dilema consiste em como saber se aquele ou esse ato administrativo possui a característica da essencialidade ou não possui, sendo, pois, inexistente, atacado pela mais severa das ilegalidades no âmbito do Direito.

Não há, na doutrina de Direito Administrativo, uma definição de ato administrativo processual inexistente; no entanto, impõe-se a análise de cada caso por intermédio de duas frentes de observação.

A primeira focada no ato administrativo processual e a outra direcionada para o processo administrativo em um contexto geral. Assim, aplicando-se os conceitos de elementos essenciais ao ato administrativo processual e ao processo administrativo, o que, nesta última

\footnotetext{
380 ZANCANER, Weida. Da convalidação e da invalidação dos atos administrativos. São Paulo: RT, 1990. p. 30 e 93
} 
hipótese, redunda na observação de suas fases e ritos previstos pelo ordenamento jurídico, é viável alcançar um conceito do vício da inexistência do ato administrativo processual.

No que tange à análise dos elementos essenciais do ato administrativo processual, nos parece que o ato realizado por particular não servidor público, exarado no âmbito de um processo administrativo, que seja de competência de um agente público (atos da comissão julgadora ou disciplinar ou do agente que decide o processo ou integrante da turma que julga o recurso, como aqueles atos do juiz, no âmbito do processo judiciário), será considerado inexistente.

Nesse caso, poderíamos citar o próprio exemplo do usurpador de função que realiza qualquer ato processual, seja a instauração de um processo administrativo, seja a prática de atos na fase instrutória, seja na emissão de pareceres, seja a decisão de um processo administrativo ou julgamento de recurso, o ato processual será inexistente.

E quando esse mesmo usurpador de função integra comissão julgadora ou disciplinar ao lado de outros agentes públicos, estes devidamente investidos em suas funções públicas, no âmbito, por exemplo, de um processo administrativo disciplinar?

Parece que o mesmo raciocínio poderia ser aplicado. In casu, além da ausência do elemento essencial referente ao agente público, verifica-se carência do elemento essencial no que toca à forma processual, isto porque o vício atinge a constituição da comissão disciplinar que não atende aos termos da ordem jurídica.

Citando-se, por exemplo, o caso da Lei $n^{0} 8112 / 90$, diploma que regula o regime disciplinar do servidor público federal, preconizam os seus artigos 149 e 150, in verbis:

Art. 149. O processo disciplinar será conduzido por comissão composta de três servidores estáveis designados pela autoridade competente, observado o disposto no $\S 3^{\circ}$ do art. 143, que indicará, dentre eles, o seu presidente, que deverá ser ocupante de cargo efetivo superior ou de mesmo nível, ou ter nível de escolaridade igual ou superior ao do indiciado. (Redação dada pela Lei $n^{\circ}$ 9.527, de 10.12.97). § $1^{\circ}$ A Comissão terá como secretário servidor designado pelo seu presidente, podendo a indicação recair em um de seus membros. § $2^{\circ}$ Não poderá participar de comissão de sindicância ou de inquérito, cônjuge, companheiro ou parente do acusado, consanguíneo ou afim, em linha reta ou colateral, até o terceiro grau. Art. 150. A Comissão exercerá suas atividades com independência e imparcialidade, assegurado o sigilo necessário à elucidação do fato ou exigido pelo interesse da administração.

Percebe-se que a qualidade de agente público para a constituição da comissão disciplinar é elemento essencial do próprio processo administrativo, uma vez que atinge todos os atos a serem exarados pela comissão. 
Destarte, a qualidade de servidor público para o fim de integrar comissão disciplinar identifica elemento que afeta a existência do ato processual administrativo e do processo administrativo como um todo. Não há, todavia, situação idêntica em relação ao agente público que integra a comissão disciplinar afrontando o preceito do $\S 2^{\circ}$, do artigo 149 supra, isto é, que seja cônjuge do investigado. Nesse caso ${ }^{381}$, o vício de invalidade toca o ato processual, com lesão ao requisito de competência/agente/capacidade na seara do ato administrativo processual, o qual será examinado a seguir.

Outros exemplos de ato processual inexistente deparamos em sede de processos administrativos que tragam no seu conteúdo condenação de particular ou de servidor público a uma prestação juridicamente criminosa ou materialmente impossível.

Pode-se, ainda, citar os atos emanados de outras partes interessadas no processo administrativo, que não o agente público com competência decisória ou apuradora dos fatos, produzindo eventual parecer final sobre o objeto processual (comissão disciplinar). É possível detectar vício de inexistência desses atos emanados pelos outros sujeitos do processo?

Em princípio qualquer ato administrativo processual pode ser acometido do vício da inexistência. Assim, invocando-se os elementos de anatomia do ato, os quais, como já aludido, encontram-se no campo da existência, constituem exemplos de ato inexistente, produzido pelas partes no processo, a petição sem assinatura ou um pedido de prova pela parte interessada cujo objeto/conteúdo seja a realização de um crime, ou materialmente impossível. Estes atos administrativos processuais também seriam passíveis da decretação de ilegalidade, na modalidade do vício referente à inexistência.

Logicamente, tais vícios de inexistência referentes aos atos emanados de outras partes interessadas no processo administrativo seriam de notória percepção e declarados inexistentes de maneira quase que imediata à sua produção; no entanto, uma vez despercebidos pela autoridade administrativa competente, a sua permanência no âmbito do processo administrativo certamente poderá levar à decretação da ilegalidade do processo administrativo na sua íntegra, ou do respectivo ato processual acometido pelo vício da inexistência.

Enfim, é aplicando-se os conceitos de elementos intrínsecos e extrínsecos, essenciais ao ato administrativo, no âmbito do ato administrativo processual e do processo

\footnotetext{
381 Essa não é a opinião de Sergio Ferraz e Adilson Dallari, pois estes acreditam que, no âmbito do processo administrativo, "[...] o ato processual praticado por agente decisório incapaz e/ou incompetente há de ser tido como inexistente. [...]" (FERRAZ, Sérgio; DALLARI, Adilson Abreu. Processo Administrativo. São Paulo: Malheiros, 2001. p. 196).
} 
administrativo em uma perspectiva geral, que se torna possível atingir o conceito do vício da inexistência do ato administrativo processual.

De relevo, ademais, o registro de que, constatado o vício da inexistência no âmbito do processo administrativo, essa lesão deve ser extirpada da orla jurídica, de forma ex tunc, não gerando quaisquer efeitos a partir do ato tocado pelo vício da inexistência. Poder-seá até declarar ilegal a íntegra do processo administrativo, dependendo da fase em que for detectado o vício, nos moldes daqueles atos processuais considerados tocados pela nulidade absoluta.

Importante ressaltar, também, que o ato administrativo processual nulo se diferencia do inexistente no que tange ao conceito. Contudo, os efeitos da constatação dos respectivos vícios serão deveras semelhantes.

Demais disso, ainda que se afirme que o ato processual inexistente não produz efeitos, porquanto é um "não-ato", que, a rigor, jamais poderia assumir o status de existência jurídica, em certas ocasiões, vem a surtir efeitos. E, neste caso, dependendo dos efeitos gerados pelo ato processual inexistente (caso de terceiros de boa - fé, por exemplo), a declaração de ilegalidade terá seu tratamento equiparado ao ato processual tocado pelo vício da nulidade absoluta, respeitando-se, evidentemente, a finalidade pública, a legalidade, os interesses de terceiros de boa-fé, a segurança jurídica, a confiança, como veremos em momento posterior na presente dissertação.

\subsubsection{Ato administrativo processual irregular}

No campo da validade do ato administrativo, como já ressaltado, é possível ao analista vir a se deparar com vícios de pequena monta, que acometem os atos administrativos em seus requisitos de validade, seja no que tange à forma, ao sujeito, ao motivo, objeto e finalidade; no entanto, devido ao reduzido grau de afetação da legalidade, essas pequenas irregularidades não chegam a tornar o ato ineficaz ou, até mesmo, poder-se-á dizer que não demandam declaração da ilegalidade.

Weida Zancaner ${ }^{382}$ atribui aos atos irregulares a alcunha de atos absolutamente sanáveis, asseverando que: "Os atos absolutamente sanáveis são os atos maculados por 
pequenas irregularidades". Ilustrando esta posição, a autora arrola como exemplos do ato administrativo irregular "[...] erros de grafia, referência inexata ao ano de publicação de uma lei, erro na capitulação de um parágrafo, quando da indicação do motivo legal que autoriza ou exige a prática do ato". Adverte, contudo, que "[...] as irregularidades que os gravam não podem comprometer a compreensão do ato ou implicar vício de causa, nem podem se constituir em erro de direito ou em erro de fato".

Transportando o conceito de irregularidade do ato administrativo para o bojo do processo administrativo, depreende-se que uma irregularidade processual tanto pode ser convalidada, quanto declarada ilegal e passível de refazimento o ato. Poderá, porém, permanecer intacto, caso seja despercebido pela Administração e/ou pelos sujeitos do processo administrativo.

Neste caso, permanecendo o ato com a sua irregularidade, não haverá qualquer indício de atuação ilegal da Administração, pois vícios de irregularidade processual não têm o condão de afetar o interesse público, os princípios da Administração Pública e do processo administrativo, prevalecendo, pois, válido, o ato processual administrativo.

Ainda que não se convalide o ato portador de pequeno vício de irregularidade, permanecerá este produzindo seus efeitos regulares, não cabendo ao interessado alegar ilegalidade do processo administrativo diante da presença deste vício de irregularidade.

Para fins de ilustrar a hipótese, veja-se o caso de uma citação equivocada do número de uma lei que fundamente a aplicação de pena ao servidor público, em sede de processo administrativo disciplinar. A referência, por exemplo, à Lei $n^{\circ} 8111 / 90$, ao invés de citar o número correto, i.é, Lei $\mathrm{n}^{\circ} 8112 / 90$, não será capaz de servir de fundamento apto para a aplicação do sistema de vícios, tornando ilegal a aplicação de penalidade disciplinar, ainda que esse pequeno vício não seja reparado pela Administração.

Desta forma, conclui-se que o vício de irregularidade do ato processual administrativo não gera a imposição de se proceder à declaração de sua ilegalidade. Neste sentido é viável até a invocação dos princípios da economia processual e da instrumentalidade das formas. Aconselhável, todavia, que se convalide o vício de irregularidade. 


\subsubsection{Ato administrativo processual anulável}

Há diferença entre o ato anulável, no âmbito do Direito Privado, e ato anulável no Direito Administrativo. Na primeira situação, a anulação se dá por vício que atinge esfera na qual não existe interesse público envolvido e será obrigação exclusiva da parte interessada, do particular, o seu apontamento, em determinado prazo, sob pena de não poder mais fazê-lo.

No Direito Administrativo, a possibilidade de se estar diante de interesse exclusivamente privado não existe e, em quaisquer hipóteses, presente se apresenta o interesse público. Nessas condições, a ocorrência de vício que conduza à anulabilidade ${ }^{383}$ é analisada à luz da sua gravidade e da viabilidade da respectiva recuperação.

Com efeito, as leis que tratam do processo administrativo, em âmbito federal (Lei $n^{\circ}$ 9784/99 - artigos 53 a 55), no Estado de São Paulo (Lei no 10177/98 - artigos 10 e 11), bem assim a Súmula STF $n^{\circ} 473$, disciplinam, como anotado anteriormente, a matéria referente à declaração de ilegalidade do ato administrativo.

E, no contexto deste quadro normativo, identifica-se uma alusão aos atos administrativos sanáveis, embora não se confunda nem se trate de institutos como o da convalidação do ato administrativo, ou do prazo estabelecido para a Administração poder proceder à declaração de ilegalidade do ato viciado, que será abordado, em particular, em momento posterior.

Pois bem, Edmir Netto de Araújo $^{384}$ conceitua o ato administrativo anulável, reportando-se a “Atos anuláveis (ou relativamente inválidos)”, e anota:

[...] a possibilidade de complementação da classificação em atos anuláveis depende de o autor admitir ou não admitir a possibilidade de não decretar a nulidade de atos administrativos eivados de vícios menos graves, que não acarretem a nulidade absoluta, ou conservar a validade desse tipo de atos (conversão, reforma, ratificação), embora permanecendo o dever de recompor a ordem jurídica ferida, pela anulação dos atos absolutamente nulos, ou pela convalidação, quando o prejuízo ao interesse público for relevante se optarmos pela anulação ou repetição do ato, nos casos de nulidade relativa.

\footnotetext{
383 Como adotamos a qualificação dos vícios do ato administrativo de Edmir Netto de Araújo, o referido autor admite atos administrativos anuláveis. Outros doutrinadores, já citados na presente dissertação, não admitem, como Hely Lopes Meirelles.
}

384 ARAÚJO, Edmir Netto de. Curso de Direito Administrativo. 5. ed. São Paulo: Saraiva, 2010. p. 495. 
Aduz, ainda, o administrativista ${ }^{385}$, no que tange ao poder ou dever de convalidar os atos anuláveis:

É mais simples constatar que, no caso da anulação, o "poder" da Súmula STF $n^{\circ} 473$ significa faculdade, escolha entre anular ou não anular o ato quando a nulidade é relativa, faculdade esta que inexiste quando a nulidade é absoluta, insanável, porque o dever da autoridade [como, aliás, afirmou Celso Antônio Bandeira de Mello, citado anteriormente], frente a uma nulidade, é restaurar a legalidade e também porque a Administração pode recompor essa legalidade tanto anulando como convalidando o ato relativamente nulo (quando a nulidade é relativa). Cabe ao administrador (e não a outro Poder) valorar internamente qual a alternativa (dentre mais de uma, todas legítimas perante o Direito) que melhor atende ao interesse público, no caso concreto. As exceções ao dever de anular constantes das leis examinadas conformam esse entendimento.

Por fim, complementa Edmir Netto de Araújo: “[...] não é proibido anular quando possível a convalidação, e não é obrigatório convalidar em qualquer caso de nulidade sanável”.

Merece destaque, ainda que de forma sintética, o estudo do instituto da convalidação do ato administrativo e suas espécies, uma vez que intimamente ligado aos atos administrativos anuláveis. Edmir Netto de Araújo ${ }^{386}$ elenca quatro tipos de convalidação: a ratificação, a conversão, a reforma e a conformação.

Das ponderações do mestre ${ }^{387}$, emerge a ratificação como a modalidade de convalidação do ato administrativo no que toca ao vício de nulidade relativa de competência, operando quando a autoridade competente para a edição do ato suprime o vício existente e o declara expressamente sanado. Na conversão, de outra parte, aproveitam-se os elementos válidos do ato relativamente nulo para se constituir novo ato. Por isso, a denominação “conversão", porquanto converte-se o primeiro ato, defeituoso, em outro ato administrativo, aproveitando-se seus elementos sem vício, sob o amparo dos princípios da conservação dos valores jurídicos, previstos no Direito Privado.

385 ARAÚJO, Edmir Netto de. A convalidação dos atos administrativos e as leis de processo administrativo. p. 64-65. In: NOHARA, Irene Patrícia; MORAES FILHO, Marco Antônio Praxedes de (Orgs.). Processo Administrativo. Temas Polêmicos da Lei 9.784/99. São Paulo: Atlas, 2011. p. 43-66.

386 ARAÚJO, Edmir Netto de. A convalidação dos atos administrativos e as leis de processo administrativo. p. 65. In: NOHARA, Irene Patrícia; MORAES FILHO, Marco Antônio Praxedes de (Orgs.). Processo Administrativo. Temas Polêmicos da Lei 9.784/99. São Paulo: Atlas, 2011. p. 43-66.

387 ARAÚJO, Edmir Netto de. A convalidação dos atos administrativos e as leis de processo administrativo. p. 56-57. In: NOHARA, Irene Patrícia; MORAES FILHO, Marco Antônio Praxedes de (Orgs.). Processo Administrativo. Temas Polêmicos da Lei 9.784/99. São Paulo: Atlas, 2011. p. 43-66. 
Prossegue o administrativista ${ }^{388}$, explicitando que a reforma se dá quando da supressão da parte viciada de determinado ato administrativo, mantendo-se a eficácia da parte não atacada pela ilegalidade. Por derradeiro, a confirmação, traz conceito do Direito Privado, oriundo dos artigos 172 a 177 do Novo Código Civil, concretizável mediante declaração das partes, em face de negócio jurídico anulável, manifestação a conter a substância do negócio e a vontade expressa de mantê-lo como está. Constitui, assim, ato jurídico bilateral de concordância, que somente os interessados podem concretizar. No Direito Administrativo, essa modalidade se diferencia das demais, tendo em vista que as outras podem ser pronunciadas de ofício ou a requerimento de interessado, pela autoridade competente ${ }^{389}$.

Weida Zancaner aponta os atos anuláveis como aqueles relativamente sanáveis ${ }^{390}$, nestes termos: “[...] são os que devem, em razão dos vícios que os eivam, ser reproduzidos validamente pela Administração Pública, isto é, devem ser convalidados”. Nesse contexto, os entendimentos de Weida Zancaner ${ }^{391}$ e de Celso Antônio Bandeira de Mello ${ }^{392}$ se distanciam, uma vez que apontam obrigação por parte do Poder público e não mera faculdade como é assinalado por Edmir Netto de Araújo. Este indica como uma possibilidade o caminho da convalidação do ato administrativo que contenha vício de nulidade relativa e que não tenha sido impugnado pelo interessado, excetuando-se o caso de vício de competência em ato de conteúdo discricionário.

Conforme já mencionado, parece-nos que a posição de Edmir Netto de Araújo ${ }^{393}$ melhor se ajusta a situações de anulabilidade e, nessa linha, oportuna a lição do administrativista: 'É mais simples constatar que, no caso da anulação, o 'poder' da Súmula STF $n^{\circ} 473$ significa uma faculdade, escolha entre anular e não anular o ato quando a nulidade é relativa, faculdade que inexiste quando a nulidade é absoluta, insanável, [...]". Conclui,

388 ARAÚJO, Edmir Netto de. A convalidação dos atos administrativos e as leis de processo administrativo. p. 56-57. In: NOHARA, Irene Patrícia; MORAES FILHO, Marco Antônio Praxedes de (Orgs.). Processo Administrativo. Temas Polêmicos da Lei 9.784/99. São Paulo: Atlas, 2011. p. 43-66.

389 Maria Sylvia Zanella Di Pietro elenca essa hipótese de confirmação em separado do instituto da convalidação e assim dispõe: "A confirmação difere da convalidação, porque ela não corrige o vício do ato; ela o mantem tal como foi praticado. Somente é possível quando não causar prejuízo a terceiros, uma vez que estes, desde que prejudicados pela decisão, poderão impugná-la pela via administrativa ou judicial” (DI PIETRO, Maria Sylvia Zanella, Direito Administrativo. 25. ed. São Paulo: Atlas, 2012. p.256).

390 ZANCANER, Weida. Da convalidação e da invalidação dos atos administrativos. São Paulo: RT, 1990. p . 88.

391 ZANCANER, Weida. Da convalidação e da invalidação dos atos administrativos. São Paulo: RT, 1990. p. 89.

392 BANDEIRA DE MELlo, Celso Antônio. Curso de Direito Administrativo. 29. ed. São Paulo: Malheiros, 2012. p. 483-485.

393 ARAÚJO, Edmir Netto de. A convalidação dos atos administrativos e as leis de processo administrativo. p. 65. In: NOHARA, Irene Patrícia; MORAES FILHO, Marco Antônio Praxedes de (Orgs.). Processo Administrativo. Temas Polêmicos da Lei 9.784/99. São Paulo: Atlas, 2011. p. 43-66. 
portanto, o autor ${ }^{394 . " A A s s i m, ~ h a ́ ~ c a s o s ~ e m ~ q u e ~ a ~ a n u l a c ̧ a ̃ o ~ e ́ ~ o b r i g a t o ́ r i a ~(n u l i d a d e ~ a b s o l u t a), ~}$ outros em que é facultativa (nulidade relativa) e outros ainda em que é vedada (prescrição, decadência). Já a convalidação é possível em certos casos, possível, mas desaconselhável em outros, e vedada em outros".

Transpondo as ponderações acima, relativas ao problema da nulidade relativa do ato, para o processo administrativo, depreende-se que o ato administrativo processual anulável será identificado quando admitir convalidação, embora possa, certamente, sofrer anulação, dependendo, como ressaltou Edmir Netto de Araújo, do interesse público envolvido no caso concreto, bem como dos limites legais para a aplicação da convalidação e para a declaração de ilegalidade, a exemplo da verificação da decadência, instituto que, a seu turno, será analisado na presente dissertação.

Interessantes, aliás, os apontamentos de Sergio Ferraz e Adilson Abreu Dallari ${ }^{395}$ quando do exercício de transposição da teoria dos vícios relativos ou sanáveis do ato administrativo para o processo. Ponderam que:

[...] O dever processual de anular os atos ilegais, de regra, preclui quando haja de incidir sobre etapas já percorridas. Enquanto aberta, i. e., enquanto em curso, a relação jurídica processual, a autotutela deverá sempre apontar para anulação do ato, consideradas e salvaguardadas as etapas do processo e, evidentemente, precedida do exercício amplo do contraditório e do direito de defesa por parte dos que possam ser atingidos.

E prosseguem os autores, “[...] Estando, contudo, o processo findo, o dever [...] de anular passa a ser metrificado à luz do princípio da segurança jurídica [...]”.

Depreende-se, pois, que o ato administrativo processual anulável segue as mesmas premissas conceituais do ato administrativo anulável, ou seja, decorre de um vício sanável no âmbito de um processo administrativo, o qual poderá, também, ser declarado ilegal, impondose sua repetição ou será passível de convalidação.

No entanto, como a dinâmica processual flui de ato em ato, até que se chegue ao ato administrativo final, ou seja, à decisão administrativa irrecorrível, a possibilidade de se anular ou convalidar um ato administrativo processual sanável irá depender da fase que se encontrar o processo: se ainda em curso ou se já terminado. Impor-se-á, ademais, a verificação do respeito aos princípios do devido processo legal, da ampla defesa e do contraditório. E mais, o exame de questões atinentes à segurança jurídica, à finalidade pública

394 ARAÚJO, Edmir Netto de. A convalidação dos atos administrativos e as leis de processo administrativo. p. 65. In: NOHARA, Irene Patrícia; MORAES FILHO, Marco Antônio Praxedes de (Orgs.). Processo Administrativo. Temas Polemicos da Lei 9.784/99. São Paulo: Atlas, 2011. p. 43-66. 
e à boa - fé, parâmetros que devem sempre ser metrificados quando nos depararmos com institutos de declaração de ilegalidade em um contexto processual administrativo. E, não há de ignorar a atenção de que se faz merecedor o instituo da decadência, a ser examinado ainda no decurso do trabalho.

Outra constatação necessária é a de que em um contexto processual, em curso, a Administração deve, preponderantemente, anular os atos atacados pela ilegalidade e refazêlos, atendo-se aos princípios do devido processo legal, da ampla defesa e do contraditório, aplicando o instituto da convalidação dentro dos limites admitidos na esfera da declaração de ilegalidade. Assim procedendo, certamente, o risco de manutenção da ilegalidade será menor, sobretudo diante de uma relação processual na modalidade restritiva (processo disciplinar) ou ampliativa de direitos (concessão de aposentadoria).

Mais uma vez, observe-se que a legislação não oferece um elenco de hipóteses de ato administrativo anulável, muito menos de casos de atos administrativos processuais anuláveis; todavia, existem parâmetros legais que definem quais as características de um vício a atingir o ato administrativo. E quando esse ataca seus requisitos de validade, seja no plano da competência, quanto da forma, ou do motivo, do objeto ou da finalidade, emergem lesões que podem se apresentar sanáveis ou não sanáveis.

Considerando, contudo, que os vícios sanáveis aceitam perfeitamente a declaração de ilegalidade do ato, a consequência desses, onde não se opera a convalidação, será igual àqueles atos acometidos por vícios insanáveis ou de inexistência, isto é, declaração de nulidade, com efeito ex tunc, resguardados os princípios da boa-fé e segurança jurídica, em quaisquer hipóteses.

\subsubsection{Ato administrativo processual nulo}

$\mathrm{O}$ ato administrativo nulo contém, na sua estrutura, vício insanável, ao qual o ordenamento jurídico em vigor reage com severa drasticidade, aplicando-lhe a declaração da ilegalidade e respectiva anulação ex-tunc, cujos efeitos retroagem, de regra, à data da edição. Edmir Netto de Araújo ${ }^{396}$ define o ato administrativo nulo: 
Atos nulos (ou absolutamente inválidos), com pelo menos um dos elementos essenciais atingido, mas de forma que os atos se tornam irrecuperáveis para o Direito, sem possibilidade de repetição convalidadora, geralmente não produzindo efeitos, a não ser em relação a terceiros de boa-fé, em certos casos, como nos contratos. A declaração de nulidade absoluta produz efeitos "ex tunc", desconstituindo "ab initio" a relação jurídica e seus efeitos, como determina a Súmula STF no 473: dos atos nulos " não se originam direitos" (embora possam decorrer certos "efeito").

Em verdade, a partir do conceito supra, surge o desafio em se diagnosticar quais os atos nulos e os atos anuláveis no âmbito do Direito Administrativo.

A doutrina analisa a incidência dos vícios de ilegalidade do ato administrativo, estudando os seus requisitos estruturais à luz das regras e dos princípios, que, como já ressaltado, sustentam-se nos elementos competência, forma, motivo, objeto e finalidade.

Celso Antônio Bandeira de Mello ${ }^{397}$, postura anotada anteriormente, classifica os atos nulos e os atos anuláveis nos seguintes moldes:

nulos: a) os atos que a lei assim o declare; b) os atos em que é racionalmente impossível a convalidação, pois, se o mesmo conteúdo (é dizer, o mesmo ato) fosse novamente produzido, seria reproduzida a invalidade anterior. [...] anuláveis: a) os atos que a lei assim os declare; b) os que podem ser repraticados sem vício. [...].

Do mesmo sentir, Edmir Netto de Araújo ${ }^{398}$, acolhendo a tese de Celso Antônio Bandeira de Melo, no que tange à diferenciação de atos nulos e anuláveis, delineia as principais diferenças no Direito Administrativo, assinalando:

Atos nulos e anuláveis coincidem, em seu regime, quanto à persistência dos atos em relação a terceiros de boa-fé, à resistência oposta pelos administrados e à retroação da eliminação dos efeitos, em relação à declaração; diferem quanto à possibilidade de convalidação (só os anuláveis), quanto à arguição do vício em juízo (os anuláveis, só se o interessado provocar) e à prescrição do direito do estado invalidar seus próprios atos ou impugná-los em juízo.

Pode-se, também, afirmar que, no âmbito do processo administrativo, os vícios de nulidade absoluta referentes ao sujeito, isto é, os pertinentes à competência e à capacidade, bem como à forma, terão um destaque maior, haja vista que são lesões que, por contarem com critérios, por vezes, mais objetivos na enunciação das regras, operarão de modo mais aparente

397 BANDEIRA DE MELlO, Celso Antônio. Curso de Direito Administrativo. 29. ed. São Paulo: Malheiros, 2012. p. 486.

398 ARAÚJO, Edmir Netto de. Convalidação do ato administrativo. São Paulo: Editora Ltr, 1999. p. 129. 
no processo administrativo, embora isso possa ocorrer desde a sua instauração até a decisão final irrecorrível.

Já os vícios referentes ao objeto, ao motivo e à finalidade, quando em curso o processo administrativo, encontrarão no polo da decisão administrativa e no do reexame (recursos), um momento propício para serem detectados. De toda forma, ainda que se dê preponderância para a eventual anulação do processo administrativo, após seu término, em razão dos vícios a aportar nulidade absoluta inquinando o motivo, a finalidade e o objeto, entendemos que o exercício de autotutela da Administração poderá ser exercido, tanto antes, quanto após a decisão administrativa irrecorrível. Isto porque não há, no ordenamento jurídico em vigor, qualquer regra ou princípio que assim proíba a Administração de fazê-lo.

\subsection{A NULIDADE NO PROCESSO ADMINISTRATIVO. O ATO ADMINISTRATIVO PROCESSUAL NULO E SUAS INCIDÊNCIAS}

Este tópico é dedicado a uma abordagem dos vícios irreparáveis, que geram a nulidade absoluta, insanável, defeitos que incidem sobre os requisitos do ato administrativo praticado no bojo de um processo administrativo geral, bem como percurso do processo administrativo disciplinar. Merece lembrar, contudo, que os atos processuais anuláveis e inexistentes - exceto em caso de convalidação, no que tange aos atos anuláveis - podem conduzir, a seu turno, à declaração da nulidade absoluta do ato administrativo processual, igualmente aos atos absolutamente nulos.

\subsubsection{Nulidade relativa ao sujeito}

Os vícios que tocam o sujeito do ato jurídico, invocando-se os conceitos da lei civil brasileira, redundarão em nulidade absoluta, quando praticado o ato por autoridade absolutamente incapaz, conforme disposto nos artigos $3^{\circ}$ e 166 , do Novo Código Civil; poderão, todavia, gerar nulidade relativa, quando praticados por autoridade relativamente incapaz, nos termos das disposições contidas nos artigos $4^{\circ}$ e 171 , do já referido novo diploma civil brasileiro. 
No Direito Administrativo, a ideia de sujeito vem contemplada com especial relevo, em razão do instituto conhecido como da competência do agente e do órgão ao qual pertence. E, cumpre lembrar, como aliás anota Edmir Netto de Araújo ${ }^{399}$, que a competência,

[...] não se presume (requer texto legal expresso), é improrrogável e intransferível, salvo previsão legal ou disposição hierárquica, é de exercício obrigatório (portanto, irrenunciável e intransigível, pelo princípio da indisponibilidade do interesse público) não podendo ser objeto de pactos que a reduzam ou impeçam seu exercício.

A partir de exame a que procede Edmir Netto de Araújo ${ }^{400}$, considerando a abrangência e a precisão de sua abordagem, oportuno o registro de casos de vícios que atingem o sujeito do ato administrativo.

Nesse diapasão, aponta o administrativista duas espécies de vícios que incidem sobre o sujeito do ato administrativo; a primeira refere-se ao vício do agente, por ausência de poder legal para agir em nome do Estado, sendo que, mesmo portador de plena capacidade civil, em um dado momento e circunstância, há afronta às regras de competência; o segundo tipo trazido à baila pelo administrativista abrange aqueles vícios decorrentes de defeito pessoal do agente, retirando, pois, a capacidade do agente para a realização do ato no momento da declaração de vontade.

Para ilustrar a primeira das hipóteses acima anotada, Edmir Netto de Araújo ${ }^{401}$ cita por exemplo, a usurpação de função pública, quando o agente atua sem estar legitimado no cargo ou função pública ${ }^{402}$; abuso, excesso ou desvio de poder, quando o agente investido na função pública age além do que a regra de competência lhe permite, sem penetrações na esfera de outro funcionário, uma vez que, quando há essa intercorrência, teremos a invasão de função, que pode ser relativa, quando a exorbitância se dá em relação a funcionário do mesmo Poder, ou até do mesmo órgão, ou absoluta, quando se pratica ato de competência de outro Poder; incompetência em razão da matéria, quando o agente é legitimamente investido e competente para exarar determinada classe de atos, no entanto, o órgão, serviço público ou

\footnotetext{
399 ARAÚJO, Edmir Netto de. Curso de Direito Administrativo. 5. ed. São Paulo: Saraiva, 2010. p. 496.

400 ARAÚJO, Edmir Netto de. Curso de Direito Administrativo. 5. ed. São Paulo: Saraiva, 2010. p. $495-$ 496; ARAÚJO, Edmir Netto de. Convalidação do ato administrativo. São Paulo: Editora Ltr, 1999. p. 78-82.

401 ARAÚJO, Edmir Netto de. Curso de Direito Administrativo. 5. ed. São Paulo: Saraiva, 2010. p. $495-$ 496; ARAÚJO, Edmir Netto de. Convalidação do ato administrativo. São Paulo: Editora Ltr, 1999. p. 78-82.

402 A usurpação de função pública acarreta o vício de inexistência do ato administrativo, quando terceiro atua como se servidor público fosse. Vide: ARAÚJO, Edmir Netto de. Convalidação do ato administrativo. São Paulo: Editora Ltr, 1999. p. 73.
} 
pessoa pública a qual o mesmo pertence não o é; incompetência em razão do grau hierárquico ${ }^{403404}$, quando se pratica ato o qual estaria reservado a seu superior.

O administrativista ${ }^{405}$ cita, outrossim, a incompetência em razão do lugar do ato $^{406}$, que se enquadra nos conceitos ${ }^{407}$ já mencionados de invasão de função relativa ou absoluta, abuso de função ou incompetência em razão da matéria; a incompetência em razão do tempo do ato ${ }^{408}$, quando o órgão ou agente administrativos não são, na oportunidade concreta, competentes para a realização do ato. Devem ser ainda observadas, no que toca à competência, noções de suplência, delegação e substituição, uma vez que, caso operadas em desconformidade com a lei, poderão gerar o vício da incompetência do agente. ${ }^{409}$

Já no que se refere à segunda noção de vício a inquinar o sujeito do ato administrativo, cingindo-se à capacidade do agente, Edmir Netto de Araújo ${ }^{410}$ conceitua como incompetência em razão de defeito pessoal do agente, e explicita que

[...]Estuda-se aqui a hipótese do agente competente, legitimado, em organismo igualmente competente para o ato, mas que, no momento da manifestação da vontade, teve esta desvirtuada por circunstâncias, definitivas ou temporárias, que determinarão ou poderão determinar a invalidação da declaração, a partir da constatação dos respectivos vícios.

Exemplifica o autor ${ }^{411}$, apontando, no tocante à pessoa do agente, os casos de loucura, embriaguez, prodigalidade, alienação dos sentidos, na ocasião do ato e

403 A expressão "incompetência de grau hierárquico" é alcunhada por Marcello Caetano. Vide: CAETANO, Marcello. Tratado elementar de Direito Administrativo. Vol. I. Coimbra: Ed. Coimbra, 1943. p. 260.

404 Edmir Netto de Araújo cita que a incompetência em razão do grau hierárquico é caso de invasão de poder na modalidade relativa. Vide: ARAÚJO, Edmir Netto de. Convalidação do ato administrativo. São Paulo: Editora Ltr, 1999. p. 80.

405 ARAÚJO, Edmir Netto de. Curso de Direito Administrativo. 5. ed. São Paulo: Saraiva, 2010. p. $495-$ 496; ARAÚJO, Edmir Netto de. Convalidação do ato administrativo. São Paulo: Editora Ltr, 1999. p. 78-82.

406 A expressão "incompetência em razão do lugar do ato" é alcunhada por Marcello Caetano. Vide: CAETANO, Marcello. Tratado elementar de Direito Administrativo. Vol. I. Coimbra: Editora Coimbra, 1943. p. 260.

407 Conforme complementação de Edmir Netto de Araújo: ARAÚJO, Edmir Netto de. Convalidação do ato administrativo. São Paulo: Editora Ltr, 1999. p. 80.

408 A expressão "incompetência em razão do tempo" é alcunhada por Marcello Caetano. Vide: CAETANO, Marcello. Tratado elementar de Direito Administrativo. Vol. I. Coimbra: Editora Coimbra, 1943. p. 260.

409 "Suplência é exercício da plena competência pelo suplente, no impedimento ou afastamento temporários ou definitivos do titular. A suplência é pessoal e incondicionada, pois o suplente é investido na função antes da vacância, por qualquer motivo, do cargo; geralmente decorre de eleição ou nomeação para cargos em colegiados. Delegação resulta de um ato específico de investidura em competências não privativas de um determinado cargo: refere-se às atribuições, e não à pessoa. [...] Substituição, também no Brasil, tem sentido diferente daquele enunciado por Velasco: o superior opera no lugar, na competência do inferior, o que significa para nós, avocação de competência" (ARAÚJO, Edmir Netto de. Convalidação do ato administrativo. São Paulo: Editora Ltr, 1999. p. 82). 
posteriormente comprovados. No que concerne à manifestação de vontade viciada do agente, tanto de forma dolosa ou culposa, pode-se citar o dolo, a simulação, a fraude e até mesmo o erro, quando grosseiro, incidentes sobre o objeto da declaração. É verdade que nesses casos se considera mais adequado enfrentar como vício o que ataca o elemento motivo do ato administrativo; mas dúvida parece não existir quanto à incidência do vício sobre a figura do agente.

Compete lembrar, ainda, que, nas hipóteses de vontade viciada do agente, podem existir circunstâncias externas, interferências de terceiros. Isto porque evidente a possibilidade de influência estranhas a atuar sobre o agente através de coação moral, física, fraude, simulação, indução a erro, desvirtuando a vontade normativa do Estado.

Com relação à participação dos terceiros ${ }^{412}$ administrados, depreende-se que podem ocorrer hipóteses de vício relativo ao sujeito, isto é, incapacidade civil do destinatário ou do contratado, falta de habilitação para manifestar a vontade em matéria específica ou, até mesmo, defeito de representação.

A teoria de vícios que aportam no plano do sujeito, desenvolvidas para o ato administrativo, pode ser transportada para o processo administrativo. A teoria, contudo, deve ser complementada para servir a um contexto diferenciado, de atividade processual da Administração, considerando-se a presença de comissões processantes disciplinares, o que, muitas vezes, importa em maior complexidade para o exame da competência, bem como da participação efetiva, tanto dos agentes, quanto de terceiros em cada ato processual administrativo realizado.

É sabido que não há consenso na doutrina quando se depara com a presença de vícios em relação ao sujeito e a consequente constatação de uma nulidade absoluta, ou de nulidade relativa ou, até mesmo, da inexistência do ato administrativo. A esse respeito, registra Edmir Netto de Araújo ${ }^{413}$, que são anuláveis os atos expedidos por agente incompetente, porque podem ser ratificados, bem como os atos portadores de vício de vontade, que podem ser elididos pela reforma ou pela confirmação; considera, porém, nulos os atos impregnados dos demais vícios que tocam o sujeito, excetuando-se o caso do usurpador de função, desde que não agente público.

No âmbito do processo administrativo, os vícios referentes à competência e à capacidade do agente público, no entanto, levarão à declaração de nulidade absoluta.

\footnotetext{
412 ARAÚJO, Edmir Netto de. Convalidação do ato administrativo. São Paulo: Editora Ltr, 1999. p. 81.

413 ARAÚJO, Edmir Netto de. Curso de Direito Administrativo. 5. ed. São Paulo: Saraiva, 2010. p. 507.
} 
Assim, conforme já analisado, pode-se detectar no panorama normativo preceitos que tratam da competência e da capacidade dos agentes públicos, protagonistas dos respectivos processos administrativos, isto é, daqueles que participarão do relação processual administrativa elaborando os respectivos atos introdutórios, integrantes de comissão disciplinar ou não, apreciando e realizando solenidades de produção de provas, elaborando pareceres, julgando o processo ou o recurso, enfim, atuando de várias formas no âmbito do processo administrativo.

Essa atuação deve seguir de forma expressa os ditames das respectivas legislações (editadas em esferas federal, estadual e municipal) no que tange às regras de competência e capacidade dos agentes.

Assim, uma vez constatado vício do agente, no âmbito do processo administrativo geral ou disciplinar, haverá nulidade absoluta no âmbito do processo administrativo. Isto, tanto em razão da ausência do poder legal para agir em nome do Estado, afrontando regras de competência no bojo do processo administrativo, quanto em face da verificação de defeito pessoal do agente, cingindo, pois, a sua capacidade no momento da declaração de vontade no âmbito do processo administrativo. Tudo em homenagem, sobretudo, ao princípio da legalidade, corolário do Estado de Direito, bem como aos princípios do devido processo legal, da ampla defesa e do contraditório, valores axiológicos que operam no processo administrativo no afã de afastar qualquer nível de ilegalidade presente.

Sergio Ferraz e Adilson Abreu Dallari ${ }^{414}$ se manifestam sobre o tema dos vícios que atingem os sujeitos em sede processual administrativa, adotando uma postura mais rígida no que concerne à repulsa do ordenamento jurídico em relação às ilegalidades constatadas. Afirmam, nesta esteira, que o ato processual praticado por agente incapaz e/ou incompetente há de ser tido como inexistente. Adotando os fundamentos dos referidos autores no tocante à impossibilidade de se convalidar atos processuais com vícios que decorram da afronta às regras de competência e capacidade dos agentes decisórios, parece mais adequado defender a teoria que, excetuando o caso de usurpador de função, conclui que estas lesões redundariam em ato processual inexistente, enquanto os demais vícios gerariam nulidade absoluta.

Há mais, a questão atinente aos outros sujeitos do processo administrativo, os denominados interessados. Sergio Ferraz e Adilson Abreu Dallari ${ }^{415}$, no campo dos terceiros interessados, ponderam em relação aos vícios relativos ao sujeito: "Quando a

\footnotetext{
414 FERRAZ, Sérgio; DALLARI, Adilson Abreu. Processo Administrativo. São Paulo: Malheiros, 2001. p. 196. 
incapacidade/incompetência disserem respeito aos interessados na relação processual o caso será de nulidade ou de anulabilidade, em cada caso identificáveis". Nesse contexto de terceiros interessados, pode-se adotar a teoria dos vícios do ato administrativo elaborada por Edmir Netto de Araújo, a qual seguimos e, dependendo das hipóteses fáticas, poderemos ter ato processual nulo, anulável, inexistente ou irregular.

A jurisprudência pátria, por intermédio do Superior Tribunal de Justiça, acompanha o entendimento analisado, reconhecendo a nulidade absoluta oriunda do vício de incompetência do agente público. Veja-se a ementa a seguir transcrita:

Procurador Autárquico. Processo Administrativo Disciplinar. Comissão. Constituição irregular (arts. 149 c.c. 150 da Lei n. 8112/90). Nulidade. 1 É nulo o processo administrativo disciplinar cuja comissão seja constituída por servidores que, apesar de estáveis, não sejam de grau hierárquico superior ou igual ao indiciado. Preserva-se, com isso, o princípio da hierarquia que rege a Administração Pública, bem como a independência e a imparcialidade do conselho processante, resguardando-se, ainda, a boa técnica processual. Inteligência dos arts. 149 e 150, ambos da Lei n. 8.112/90, com as alterações trazidas pela Lei n. 9.527/97. [...] (STJ. RESP 152.224/PB, 5 TURMA, rel. Min. Jorge Flaquer Scarterzini, DJ 07.08.2000).

Em outro julgado do STJ, vem abordada a questão do ato processual viciado pela incompetência da autoridade que instaurou o processo disciplinar e que gera a nulidade absoluta. Assim se manifestou a Corte:

EMENTA: Direito Administrativo. Ministério Público do estado do Amapá. Competência para autorizar a instauração de processo disciplinar. Compete ao Conselho Superior do Ministério Público [...] autorizar a abertura de processo disciplinar contra seus membros, estando nulo o ato com essa finalidade, praticado pelo Procurador Geral, [...] (STJ. ROMS 4475/AP, DJ. 11.03.1996, p. 6642, Rel. Min. Cid Flaquer Scartezzini).

Mais um exemplo de pronunciamento judicial, oriundo do STJ, aborda o problema do vício a atingir a delegação de competência, afigurando-se esta ilegal no âmbito do processo administrativo disciplinar. Manifesta-se referido Tribunal superior:

EMENTA: Administrativo. Processo Disciplinar. Delegação de Competência. Legislação Anterior. Possibilidade não prevista na Lei Vigente. 1 A Lei Complementar Estadual n. 39/90 que autorizava a delegação de competência para a instalação de processo administrativo não mais vigorava à época da instauração do procedimento, pelo contrário, estava em vigência a Lei Complementar n. 68/92, que atribui, especificamente, a determinados agentes, a competência para este mister [...] está assim eivada de nulidade a portaria de instauração do procedimento, pois subscrita por agente que atuava no exercício de função delegada [...] (STJ. ROMS 9584/RO, DJ 19.06.2000, p. 211, rel Min. Fernando Gonçalves). 
Por fim, parece razoável apontar vício muito comum no bojo dos processos administrativos disciplinares e que investe no plano da capacidade mental do agente público investigado. Trata-se do incidente de sanidade mental, que deve ocorrer quando surge dúvida sobre a sanidade mental do respectivo servidor, sob pena de nulidade absoluta. Aqui, colaciona-se julgado do STJ, que se refere ao artigo 160, da Lei $n^{\circ} 8112 / 90$, e que determina:

EMENTA: Administrativo. Servidor Público. Processo Administrativo Disciplinar. Demissão. Nulidade. Incidente de Sanidade mental. Surgindo no curso do processo disciplinar dúvida razoável acerca da sanidade mental do servidor, a comissão processante deve propor à autoridade competente que ele seja submetido a uma avaliação médica, na forma do artigo 160 da Lei n. 8112/90. Segurança concedida (STJ. MS 7.291/DF, DJ 23.04.2001, p. 117, rel. Min. Felix Fischer).

\subsubsection{Nulidade relativa à forma}

No Direito Brasileiro, a exigência de observância das formas e das formalidades, segundo doutrina de Edmir Netto de Araújo ${ }^{416}$, é garantia dos administrados contra eventuais arbitrariedades e, também, fator de credibilidade e de estabilidade das relações jurídicas. Complementando esta ideia, pondera o autor que, ao contrário do que ocorre em outros países $^{417}$, a nulidade absoluta é determinada pela inobservância de forma essencial, como tal descrita pela lei, conforme artigos 185 e 166, IV e V, do Código Civil.

Depreende-se desses registros que existe certa diferenciação entre os conceitos de forma e de formalidade. A forma se vincula à própria declaração de vontade, ou seja, corresponde à exteriorização da vontade do sujeito, enquanto a formalidade diz respeito às solenidades que se devem cumprir para a constituição da declaração.

Nesse sentido, afirma Edmir Netto de Araújo ${ }^{418}$, "Formas dizem respeito à própria declaração de vontade, e formalidades (também consideradas formas, para esse fim) podem referir-se a solenidades, procedimentos ou pressupostos intermediários indispensáveis para a formação da declaração".

\footnotetext{
416 ARAÚJO, Edmir Netto de. Curso de Direito Administrativo. 5. ed. São Paulo: Saraiva, 2010. p. 497.

417 No Brasil, ao contrário do que ocorre em outros países, a noção de essencialidade das formas está objetivada na lei, pouco sobrando à interpretação, como afirma Marcello Caetano em: CAETANO, Marcello. Tratado elementar de Direito Administrativo. Vol. I. Coimbra: Editora Coimbra, 1943. p. 260.

418 ARAÚJO, Edmir Netto de. Curso de Direito Administrativo. 5. ed. São Paulo: Saraiva, 2010. p. 497.
} 
Edmir Netto de Araújo ${ }^{419}$ assim exemplifica alguns casos envolvendo vícios de forma no Direito brasileiro:

[...] tanto é defeito de forma uma declaração de utilidade pública feita através de "Resolução" e não decreto, como uma contratação administrativa consumada sem a licitação precedente (exceto nos casos de dispensa, inexigibilidade ou vedação da mesma, legalmente determinados), como ainda uma demissão de funcionário público efetivada sem o devido processo legal (disciplinar ou judiciário), no qual the tenham sido assegurados $\mathrm{o}$ contraditório e a ampla defesa. Ou a nomeação de funcionário para o cargo efetivo (não em comissão) sem a precedente aprovação em concurso público.

No tocante ao processo administrativo, faz-se necessário recordar o princípio da obediência às formas e aos procedimentos que vige no seu âmbito. Referido cânone, como verificado em tópicos anteriores desta dissertação, também vem denominado de informalismo por alguns doutrinadores e, por outros, de formalismo moderado.

É que será por intermédio da aplicação do princípio da obediência às formas (formalismo moderado) que trilharemos o caminho para identificação do que deve ser passível de declaração de ilegalidade por vício de forma do ato administrativo processual; isto sem ignorar a relevância da noção de essencialidade da forma e a da formalidade no âmbito do processo administrativo.

O princípio da obediência às formas e aos procedimentos impõe à Administração o atendimento das formas e dos procedimentos especiais previstos pela legislação processual pertinente. Não significa, no entanto, que a forma e as formalidades constituam metas a serem perseguidas. O que se deve ter como norte é a finalidade que se deseja atingir. Na prática, pois, o princípio se volta preponderantemente para a Administração, uma vez que a flexibilidade do formalismo deve somente operar em prol do administrado, respeitando-se, em quaisquer perspectivas o interesse público objeto do processo administrativo.

Ressalta-se que, no âmbito do Direito Administrativo, adquire conotação de essencialidade a forma, porquanto se traduz dever da Administração a sua observância, o prescrito em lei. Demais disso, emerge a imposição de publicidade dos atos administrativos, hoje alçada a princípio fundamental da atividade administrativa, por força do preceito consagrado no caput, do artigo 37, da Constituição Federal de 1988, cuja finalidade é assegurar a divulgação e disponibilizar a informação de caráter público. Busca-se a garantia da transparência às ações da Administração, salvo eventuais exceções referendadas pelo dever de sigilo. 
A publicidade ${ }^{420}$ deve abranger a parte dispositiva do ato administrativo, bem como sua respectiva motivação, seja em relação a atos de natureza vinculada ou discricionária. Poderá se apresentar num plano extensivo ou, ainda, de molde restrito, a depender das previsões legais atinentes que regulam a edição do respectivo ato.

Motivação ${ }^{421}$ corresponde à explicitação dos pressupostos fáticos que levaram a Administração a editar o ato administrativo. A motivação é elemento obrigatório para os atos administrativos vinculados e nas hipóteses em que haja prévia predeterminação da lei ou ato normativo que assim o obrigue. Autoriza, contudo, dispensa em se tratando de atos discricionários. Merece ressalva, ainda, a lição de Edmir Netto de Araújo ${ }^{422}$ assinalando que “[...], se o agente motivar ato que, por ser discricionário, não estava obrigado a fazê-lo, aos motivos invocados para a prática desse ato se vinculará (Teoria dos motivos determinantes) ${ }^{423}$ $[\ldots] "$.

Convém registrar que, decorrência dos apontamentos acima, dessume-se que, na prática, a Administração não poderá alterar as fases de determinado processo, bem assim não lhe será permitido atuar em desacordo com as previsões procedimentais previstas para qualquer espécie de processo administrativo.

Outra observação que merece destaque diz respeito à necessidade de motivação da decisão proferida em sede de processo administrativo. Configura, esta, requisito essencial; uma formalidade cuja presença é exigida em todos os atos decisórios do processo administrativo, sob pena de se apresentarem atingidos pelo vício de forma, afrontando-se,

\footnotetext{
420 ARAÚJO, Edmir Netto de. Convalidação do ato administrativo. São Paulo: Editora Ltr, 1999. p. 85-87.

421 ARAÚJO, Edmir Netto de. Curso de Direito Administrativo. 5. ed. São Paulo: Saraiva, 2010. p. 498.

422 ARAÚJO, Edmir Netto de. Curso de Direito Administrativo. 5. ed. São Paulo: Saraiva, 2010. p. 498.

423 A teoria dos motivos determinantes, a qual se costuma atribuir a formulação a Jèze, segue a premissa pela qual os fatos e situações que serviram de suporte ao agente para determinar a sua decisão integram a validade do ato, e, nesse contexto, referida teoria também se torna de extrema utilidade na constatação dos vícios de motivo do ato administrativo. Na doutrina de Jèze, encampada por Edmir Netto de Araújo, adotam-se como regras principais da referida teoria dos motivos determinantes, sob pena de declaração de ilegalidade, as seguintes premissas: “a) A motivação do ato só é obrigatória por lei ou regulamento, e nestes casos sua ausência é motivo de nulidade; b) Os motivos invocados no ato, obrigatória ou espontaneamente, presumem-se (presunção "júris tantum”) determinantes, ou seja, que influíram decisivamente na formação da vontade; c) A obrigação de fundamentar o ato impõe exposição clara e precisa dos motivos, que devem ser materialmente exatos; d) O motivo determinante deve ser lícito (conforme a lei e o interesse público), integrado na competência do agente, e em harmonia com a finalidade a que se refere o ato; e) Cumulando-se vários motivos determinantes, a ilicitude de um deles não induz a invalidade do ato, se os demais foram suficientes para sua legitimação; f) $\mathrm{O}$ Poder Judiciário só investiga os motivos determinantes quando impugnados pela parte, que arcará com ônus da prova; nesse exame não se inclui o da valoração interna da conveniência ou oportunidade da providência que se impunha tomar". Vide: JÈZE, Gaston. Les príncipes géneraux Du Droit Administratif. 3.ed. Paris: Ed. Giard e Briére, 1925 a 1936; ARAÚJO, Edmir Netto de. Convalidação do ato administrativo. São Paulo: Editora Ltr, 1999. p. $90-91$.
} 
pois, as garantias do devido processo legal, da ampla defesa e do contraditório, já acima metrificados.

Ademais, deve a Administração garantir a obediência, sobretudo no processo administrativo, aos princípios do devido processo legal, ampla defesa e contraditório, cânones com o caráter de diretriz para a atuação da Administração pública.

Sensíveis ao assunto, Sergio Ferraz e Adilson Abreu Dallari ${ }^{424}$ assim se manifestam sobre a questão da forma e do processo administrativo:

A forma constitui, inequivocamente, um elemento de grande relevância no ato administrativo. Mas esse relevo adquire especial significação no processo, inclusive no administrativo, eis que aqui ela assume, inclusive, as finalidades de assegurar a celeridade, a razoabilidade, a igualdade e a eficiência na atuação processual.

No entanto, ponderam os autores ${ }^{425}$, invocando o axioma da instrumentalidade das formas, quando aduzem "Só que de braços dados com esse relevo vai também o conceito de instrumentalidade das formas. Isso é, se bem que a forma compareça aqui, segundo visto acima, como garantia de realização efetiva de supremos princípios, ela, por isso mesmo, não é um fim em si [...]”.

De outra parte, partindo de análise pontual da Lei $n^{\circ}$ 9784/99, José dos Santos Carvalho $\mathrm{Filho}^{426}{ }^{427}$, em relação ao cumprimento das formas e formalidades do processo administrativo, diante do princípio da observância das formas (formalismo moderado), anota que:

[...] Sem dúvida, se a formalidade é essencial à referida garantia, a forma do ato não pode dispensá-la; se o fizer, cumpre invalidar o ato por vício de forma. Quando é essencial, pretende-se que a formalidade se entrelace com o próprio fundo, de modo que sua observância agride a garantia do direito do administrado. Quando a lei, por exemplo, exige o contraditório antes do ato punitivo, é porque sua dispensa viola a garantia do direito de defesa, e por isso, torna-se essencial essa formalidade.

\footnotetext{
424 FERRAZ, Sérgio; DALLARI, Adilson Abreu. Processo Administrativo. São Paulo: Malheiros, 2001. p. 196.

425 FERRAZ, Sérgio; DALLARI, Adilson Abreu. Processo Administrativo. São Paulo: Malheiros, 2001. p. 196.

426 CARVALHO FILHO, José dos Santos. O formalismo moderado como dogma do processo administrativo. p. 109. In: NOHARA, Irene Patrícia; MORAES FILHO, Marco Antônio Praxedes de (Orgs.). Processo Administrativo. Temas Polêmicos da Lei 9.784/99. São Paulo: Atlas, 2011. p. 101-120.

427 José dos Santos Carvalho Filho elaborou o artigo: "O formalismo moderado como dogma do processo administrativo", no qual analisa a incidência desse axioma nas fases introdutória, de instrução e decisória do processo administrativo federal regido pela Lei 9.784/99. Vide: CARVALHO FILHO, José dos Santos. O formalismo moderado como dogma do processo administrativo. In: NOHARA, Irene Patrícia; MORAES FILHO, Marco Antônio Praxedes de (Orgs.). Processo Administrativo. Temas Polêmicos da Lei 9.784/99. São Paulo: Atlas, 2011. p. 101-120.
} 
Concluindo, o autor realça com propriedade ${ }^{428}$ :

Não se quer dizer que formas e formalidades sejam elementos absolutamente dispensáveis no processo de exteriorização das manifestações volitivas da Administração: não o são, nem podem sê-lo. Também não se pretende demarcar o processo administrativo com o princípio do informalismo radical, já que naquele há formalidades a serem fatalmente acolhidas. $\mathrm{Na}$ verdade, o informalismo retrata o sentido de que o processo não está sujeito a formas rígidas.

É dizer que o ato processual administrativo, cujos elementos forma e formalidade se caracterizem como essenciais, são aqueles que contam com previsão no ordenamento jurídico quanto às respectivas condições de forma e formalidades necessárias à regular edição. Isso inclui: o respeito expresso aos procedimentos previstos nas leis do processo administrativo, a harmonização aos valores que decorrem dos princípios de Direito Administrativo, com foco especial para o princípio da publicidade, o cumprimento dos princípios norteadores do processo administrativo, como a garantia do devido processo legal, a ampla defesa e o contraditório, dentre outros.

Destarte, uma vez eivados de vício quanto à forma e às formalidades, os atos processuais se apresentam merecedores da decretação de nulidade absoluta, aqui não se aplicando o princípio da moderação do formalismo.

Por outro lado, na hipótese de ato processual administrativo liberado do atendimento dos elementos forma e formalidades, esses fatores deixam de apresentar a conotação de essencialidade para a validade daquele. Atingida a finalidade e não resultando prejuízo para a defesa, o ato processual poderá ser aproveitado, ainda que se detecte eventual ilegalidade. Isso desde que o interesse público não tenha sido lesado, privilegiando-se a moderação da obediência à forma no bojo do processo administrativo e utilizando-se de parâmetros do processo judicial, em especial, do princípio da instrumentalidade das formas e do princípio da economia processual, já referidos.

Nesse diapasão, vejamos a jurisprudência que se revela importante abordar, haja vista que as noções de essencialidade dos atos processuais, bem como da aplicação do princípio da moderação do formalismo, na prática, podem levar a hipóteses diferenciadas, às vezes, não contempladas na legislação específica que cuida dos processos administrativos, esfera em que, eventualmente, se constatará a nulidade do ato processual administrativo pelo vício de forma e formalidade.

\footnotetext{
428 CARVALHO FILHO, José dos Santos. O formalismo moderado como dogma do processo administrativo. p. 118. In: NOHARA, Irene Patrícia; MORAES FILHO, Marco Antônio Praxedes de (Orgs.). Processo Administrativo. Temas Polêmicos da Lei 9.784/99. São Paulo: Atlas, 2011. p. 101-120.
} 
Assim, colacionamos exemplo oriundo do Supremo Tribunal Federal, no que diz respeito ao cerceamento da ampla defesa e do contraditório no bojo de processo administrativo disciplinar federal, com o foco na ausência dos procedimentos previstos pela respectiva legislação processual administrativa federal:

EMENTA: Servidor Público. Aplicação da pena de advertência sem a instauração de sindicância na qual se daria o exercício da ampla defesa dos que vieram a ser punidos. Nulidade. Do sistema da Lei 8112/90 resulta que, sendo a apuração de irregularidade no serviço público feita mediante sindicância ou processo administrativo, assegurada ao acusado ampla defesa (art. 143), um desses dois procedimentos terá de ser adotado para essa apuração, o que implica dizer que o processo administrativo não pressupõe necessariamente a existência de uma sindicância, mas, se o instaurado for a sindicância, é preciso distinguir: se dela resultar a instauração do processo administrativo disciplinar, é ela mero procedimento preparatório deste, e neste é que será imprescindível se dê a ampla defesa do servidor; se, porém, da sindicância decorrer a possibilidade de aplicação de penalidade de advertência ou de suspensão de até 30 dias, essa aplicação só poderá ser feita se assegurada ao servidor, nesse procedimento, sua ampla defesa. No caso, não se instaurou nem sindicância, nem processo administrativo, e sem se dar, por isso mesmo, qualquer oportunidade de defesa aos impetrantes, foi-lhes aplicada a pena de advertência, por decisão que foi tomada, como se vê da cópia a fls. 10, em processo administrativo contra terceiro e no qual os impetrantes constituíram a comissão de inquérito. Recurso Ordinário a que se dá provimento (RMS 22789/RJ, DJ 25.06.99, p. 45, Rel Min. Moreira Alves, dia 04.05.1999).

Nessa trilha, outro julgado do STF, em que o Pretório Excelso alude à Súmula 20 de sua autoria, in verbis:

É necessário processo administrativo, com ampla defesa, para demissão de funcionário admitido por concurso (Súmula 20, STF).

No inquérito administrativo, destinado a apurar a falta de funcionário e a aplicação da respectiva pena de demissão, deve ser-lhe assegurada ampla defesa (STF, RDA 47/108).

É nula a demissão de funcionário com base em processo administrativo, no qual não lhe foi assegurada ampla defesa (STF, RDA 73/136).

Podemos nos deparar, em certas circunstâncias do processo administrativo, com a aplicação do princípio do formalismo moderado, sincronizado, em certa medida, com o mencionado princípio que proclama "não há nulidade sem prejuízo". Nesta esteira, a seguinte decisão:

PROCESSO ADMINISTRATIVO DISCIPLINAR. DIREITO DE DEFESA. AUSÊNCIA DE PREJUÍZO. Mandado de segurança. Processo Administrativo. Direito de defesa. Nulidade. O funcionário público, como 
corolário do direito de defesa, tem o direito de acompanhar a inquirição de testemunhas. A inobservância dessa regra acarreta nulidade. Todavia, somente declarada, comprovado prejuízo para a parte a quem a solenidade aproveita. Não existe quando a conclusão não se apoiou nos esclarecimentos verbais, no caso, coincidentes com o depoimento do servidor. (STJ - RMS 178-SC - Rel Min. Vicente Cernicchiaro - j. 1.10.90).

Em outro julgado, mais recente, que encampa noção de nulidade vinculada a prejuízo para a defesa em processo administrativo, assinala-se:

EMENTA: Administrativo. Servidor público. Processo administrativo Disciplinar. Demissão. Nulidade. Direito não Demonstrado. Acusados. Depoimento em Conjunto. Testemunha. Oitiva Informal. 1 Não demonstrada, de plano, a alegada falta de citação do relatório final, não há como se reconhecer, nesse ponto, a violação ao direito do impetrante, por ausência de provas. $2 \mathrm{O}$ fato de a comissão processante ter ouvido informalmente determinada testemunha não acarreta nulidade, se na conclusão do processo disciplinar foram consideradas apenas provas contidas nos autos, sem qualquer referência àqueles contatos. $3 \mathrm{~A}$ tomada de depoimentos dos diversos acusados em conjunto - e não separadamente, como preconiza o art. $159, \S 1^{\circ}$, da Lei n. 8112/90 - não implica, por si só, em nulidade do processo, se não trouxe prejuízo à defesa. Segurança denegada (STJ. MS 7059/DF, DJ 02.05.2000, p. 86, Rel. Min. Felix Fischer).

De valor, ainda nesta seara, entendimento perfilhado pelo Tribunal de Justiça de São Paulo, em julgado que cuida da obrigatoriedade de citação no âmbito do processo administrativo, que tangencia tanto o princípio da ampla defesa, do contraditório e do devido processo legal, quanto o princípio da publicidade, todos incidindo sobre o processo administrativo:

O funcionário, sujeito a processo administrativo, deve ser citado para acompanhar os atos da instrução e produzir a defesa que tiver (TJSP, RDA $54 / 264)$.

Na espécie, o interessado não foi citado para o início do processo; e com isso impedido esteve não só de tomar conhecimento do inteiro teor da acusação como ainda não teve a possibilidade de assistir, impugnar e reinquirir as testemunhas ouvidas (TJSP, RDA 54/365).

Com relação à necessidade de motivação do ato administrativo processual, importante se revela a jurisprudência emanada do Superior Tribunal de Justiça:

A decisão que afasta previamente o magistrado de suas funções (art. 27 da Loman) é ato administrativo constitutivo, pois modifica a relação jurídica existente entre o destinatário e a Administração. Assim, essa decisão, por força do art. 93, X, da CF/1988, deve, obrigatoriamente, vir acompanhada de motivação sob pena de nulidade daquele ato, por falta de requisito obrigatório. Essa exigência constitucional deve ser entendida como critério de sua validade. Precedentes citados do STF: RTJ 163/1.059; do STJ: RMS 
12.856-PB, DJ 1\%/7/2004, e AgRg no REsp 258.949-DF, DJ 11/11/2002.RMS 18.832-RJ, Rel. Min. Hélio Quaglia Barbosa, julgado em 28/3/2006.

Ainda, com relação à motivação, outro aresto do Superior Tribunal de Justiça aponta:

AGRG no ARESP 153140 /SE - Agravo Regimental no Agravo em Recurso Especial - 2012/0045363-0 - Ministro Herman Benjamin (1132) 22/05/2012 - Ementa - Processual civil. Ato administrativo. Ausência de motivação. - Nulidade. 1. O ato administrativo que determina a remoção de servidor público deve ser motivado. Precedentes do STJ. 2. Agravo Regimental não provido.

\subsubsection{Nulidade relativa ao objeto, motivo e finalidade}

O objeto do ato administrativo é constituído pelo seu conteúdo e este deve ser lícito sob pena de nulidade absoluta. Edmir Netto de Araújo ${ }^{429}$ define o objeto do ato jurídico como "[...] a declaração de vontade de que sobre ele versa, exteriorizada em certa forma, [...]". Nesse sentido, cabe recordar o preceito do inciso II do artigo 166, do Novel Código Civil, tratando do negócio jurídico, preconizando que o seu objeto deve ser lícito, possível e determinável, sob pena de nulidade.

No âmbito do Direito Administrativo, a línea "c" do artigo 2º da Lei no 4717/65, citada na presente dissertação, estabelece que a ilegalidade do objeto é causa de nulidade, sendo que o seu parágrafo único prevê que a ilegalidade do objeto ocorre quando o resultado do ato traz como consequência a violação de lei, regulamento ou outro ato normativo.

Depreende-se, portanto, que a constatação de vício a lesar o objeto do ato administrativo gera, em regra, nulidade absoluta. Isto em decorrência do ato processual nulo. Há, contudo, exceções identificadas por objeto cujo conteúdo se defina em uma conduta criminosa, situação reveladora do vício de inexistência a atacar o ato administrativo processual; este, no entanto, também sofrerá declaração de nulidade absoluta.

Edmir Netto de Araújo ${ }^{430}$, com relação aos vícios referentes ao objeto do ato administrativo, complementa: "A ilicitude do objeto do ato administrativo se configura quando este está em desacordo com normas jurídicas pertinentes, ou então, quando não

\footnotetext{
429 ARAÚJO, Edmir Netto de. Convalidação do ato administrativo. São Paulo: Editora Ltr, 1999. p. 83.

430 ARAÚJO, Edmir Netto de. Curso de Direito Administrativo. 5. ed. São Paulo: Saraiva, 2010. p. 496.
} 
corresponde ao interesse público que motivou a declaração de vontade, motivo este que, se ilícito ou inexistente, comunicará o defeito à finalidade".

Importante destacar que, na maioria das vezes, a ilegalidade não afeta unicamente o objeto, ou seja, não opera de modo isolado. Na realidade, quando diante de objeto ilegal surge um indicativo de que em algum outro momento da formação do ato também ocorreram ilegalidades, mormente em pontos de intervenção do agente e na valoração dos motivos em relação ao interesse público e à própria simetria que se exige em relação à finalidade do ato administrativo.

Nesse diapasão, Edmir Netto de Araújo ${ }^{431}$ ensina:

Haverá, portanto, objeto viciado quando se faz a declaração sobre objeto ilícito (concessão para jogos proibidos, p. ex., ou para geração de energia atômica), impossível (nomeação de pessoa inexistente, p. ex.), ou indeterminado (como nomeação de alguém para cargo não especificado, ou decreto expropriatório sobre área sem contornos determinados).

Estará inquinado de ilicitude o objeto do ato administrativo quando este confrontar as normas jurídicas existentes, ou quando não houver correspondência entre o objeto e o interesse público que motivou a declaração de vontade do agente. E, quando este interesse público se revestir de ilegalidade, o defeito incidirá também sobre a finalidade do ato administrativo.

Assim se posiciona Edmir Netto de Araújo ${ }^{432}$, com relação ao objeto ilícito, tendo em vista a não correspondência com o interesse público que motivou a declaração de vontade do agente:

Quando se faz declaração de vontade sobre objeto ilícito (p. ex., concessão de serviço público de geração de energia atômica, ou para jogos proibidos, ou para serviços jurisdicionais) [...] o agente terá tido sua vontade desvirtuada já ao valorar o interesse público e transformá-lo em motivo, por dolo seu, ou então por erro seu quanto à matéria ou pessoa que integram o conteúdo do ato, e por simulação ou fraude suas (o que significa dolo também). Em qualquer caso, terá ocorrido, quer a intenção do agente em declarar objeto ilícito, diretamente ou através de simulação ou fraude, ou então negligência ou imprudência ao caracterizar o objeto em relação a motivo e finalidade.

Não há como ignorar, também, a possibilidade da declaração de vontade do agente público sofrer vício provocado por ato de terceiros, não correspondendo ao interesse

\footnotetext{
431 ARAÚJO, Edmir Netto de. Curso de Direito Administrativo. 5. ed. São Paulo: Saraiva, 2010. p. 496.

432 ARAÚJO, Edmir Netto de. Convalidação do ato administrativo. São Paulo: Editora Ltr, 1999. p. 83.
} 
público e ao motivo em que o agente se apoia após valorar o interesse público em concreto. Aduz Edmir Netto de Araújo ${ }^{433}$ que isso

[...] acontece em decorrência de simulação ou fraude (dolo) de terceiros, e outras hipóteses de indução a erro quanto ao objeto, mesmo aquelas referentes à coação moral ou física praticada por terceiros, ocasião em que o vício terá ocorrido no momento imediatamente anterior ao do objeto, que será ilícito embora tenha havido um interesse público e correspondente motivo, mas o objeto a eles não corresponderá (a declaração de vontade, singelamente e por si só considerada) pelas circunstâncias mencionadas.

A figura do objeto impossível refere-se a algo que se apresenta inviável, inalcansável, naquele determinado tempo e lugar, tanto de fato quanto de direito. Sobre a impossibilidade do objeto, afirma Edmir Netto de Araújo ${ }^{434}$ :

A declaração de objeto impossível pode ser fruto de dolo, erro ou coação. A nomeação de pessoa inexistente pode ser nulidade insanável ou mesmo sanável no caso de erro, conforme a gravidade. A nomeação de pessoa errada (nomeia-se José João pensando ser João José) pode não ser vício do objeto, mas do agente, por erro ou dolo, e também pode ser insanável ou sanável, conforme a gravidade do erro.

Em relação ao objeto indeterminado do ato administrativo, o vício se revela pela situação de incerteza que transmite ao conteúdo do ato. Edmir Netto de Aráujo ${ }^{435}$ traz como exemplos, “[...] a nomeação para cargo não especificado, ou o decreto expropriatório sobre área sem contornos estabelecidos [...]". E complementa, advertindo que "[...] em qualquer hipótese, o objeto incerto só pode ser fruto de dolo, erro, coação ou negligência/imprudência/imperícia (culpa), a situar o defeito em outro momento da formação do ato".

O motivo do ato administrativo é o pressuposto de fato causador da ação do agente público dentro dos limites do interesse público. O Novel Código Civil prevê no inciso III, do seu artigo 166, que é nulo o negócio jurídico quando o motivo determinante, comum a ambas as partes, for ilícito.

De sua parte, a alinha "d" do artigo $2^{\circ}$, da Lei no 4717/65, reza que são nulos os atos administrativos pela inexistência dos motivos. E o parágrafo único, do preceito citado, explicita que a inexistência dos motivos se verifica quando a matéria de fato ou de direito, em

\footnotetext{
433 ARAÚJO, Edmir Netto de. Convalidação do ato administrativo. São Paulo: Editora Ltr, 1999. p. 83.

434 ARAÚJO, Edmir Netto de. Convalidação do ato administrativo. São Paulo: Editora Ltr, 1999. p. 84.

435 ARAÚJO, Edmir Netto de. Convalidação do ato administrativo. São Paulo: Editora Ltr, 1999. p. 84.
} 
que se fundamenta o ato, é materialmente inexistente ou juridicamente inadequada ao resultado obtido. Pode-se afirmar que a constatação de ilegalidade a atingir o motivo do ato administrativo gera nulidade absoluta.

José Cretella $\mathrm{Jr}^{436}$ ensina que o motivo é o "[...] suporte fático do ato, sobre o motivo incide a vontade do agente administrativo, valorando-o, pesando-o, à luz do interesse público, balizado pelo texto legal [...]”.

Edmir Netto de Araújo ${ }^{437}$ realiza uma explanação clara do que vem a se constituir em motivo do ato administrativo, senão vejamos:

Isso significa o seguinte: diante da ocorrência de certo evento material ou fato jurídico, ou da constatação de determinada situação jurídica, o sujeito (Estado, por seus governantes, legisladores, dirigentes, agentes administrativos que podem ser a mesma pessoa que vai praticar o ato, ou outras) compara essas circunstâncias com um interesse público concretamente existente (prestação regular e contínua de um serviço público, p. ex.) e conclui que se impõe a tomada de certa providência (ato administrativo) para a realização prática e operante daquele interesse público concreto.

Intimamente vinculada ao conceito do motivo do ato administrativo emerge a ideia da motivação, ou móvel, bem como da teoria dos motivos determinantes, sendo que essas duas últimas já foram objeto de análise no que tange ao vício de forma do ato administrativo processual. Nas palavras de Edmir Netto de Araújo 438 , "Móvel não é o mesmo que motivo: é 'representação subjetiva, psicológica, interna, do agente, e corresponde àquilo que suscita a vontade do agente"'.

E o autor aduz ${ }^{439}$, no que tange à constatação do vício inerente ao motivo do ato administrativo, "Pode-se concluir que o vício ocorre pela não correspondência, por qualquer razão, entre o móvel e o motivo que o interesse público concreto determina”.

A finalidade do ato administrativo é o elemento teleológico, o fim, a pretensão administrativa para a qual o conteúdo do ato deve se dirigir e atingir. Do tema trata a alinha "e" do artigo $2^{\circ}$, da Lei $\mathrm{n}^{\circ} 4717 / 65$, que declara a nulidade do ato administrativo pelo vício designado de desvio de finalidade, sendo que o respectivo parágrafo único fixa o conceito de desvio de finalidade do ato administrativo, indigitando a situação em que o agente pratica o 
ato visando a fim diverso daquele nele previsto, explícita ou implicitamente. Assim, a constatação de ilegalidade na finalidade do ato administrativo gera nulidade absoluta.

$\mathrm{Na}$ doutrina de José Cretella Junior ${ }^{440}$, a finalidade se diferencia do motivo do ato administrativo, uma vez que a finalidade representa "[...] o resultado final que o objeto deve atingir, ou seja, o resultado que determina o efeito jurídico produzido pelo ato". Complementa Edmir Netto de Araújo ${ }^{441}$, com relação à finalidade do ato administrativo, "Além disso, a finalidade deve ser específica do serviço e do interesse público considerado, de acordo com a regra de competência, e não qualquer finalidade, embora igualmente de interesse público, sob pena de desvio de finalidade e, geralmente, vício de incompetência”.

Depreende-se dessas observações que o vício incidente no elemento finalidade do ato administrativo decorre da ação do agente público. Nesse contexto, na realidade, quando se constata um defeito de finalidade, o vício já ocorreu em momento anterior à formação do ato, sendo que somente existirá vício de finalidade, propriamente dito, nas palavras de Edmir Netto de Araújo ${ }^{442}$, “[...] por erro ou dolo quanto à valoração do interesse público de que se trata, ou quando, no lapso entre a formação do ato e a realização efetiva de sua finalidade, tal interesse público deixar de existir, ou deixar de ser válido".

Aqui, merece a transcrição de exemplo formulado por Edmir Netto de Araújo ${ }^{443}$, quando compara o processo de formação e concretização do ato administrativo, com foco na finalidade do ato, à dinâmica do "arco e flexa", senão vejamos:

[...] a finalidade é o alvo [...]. Se a flexa é dirigida pelo arqueiro ao alvo, com pontaria certa, sem desvios (na forma correta) e se o arqueiro agiu corretamente, e não há defeitos nem no arco, nem na flexa, esta, ao ser disparada, atingirá o alvo. Isto só não ocorrerá por defeito do arqueiro (pontaria, firmeza, desejo de atingir o alvo), do arco (pressupostos materiais), da flexa (torta, furada) ou do tempo (vento, chuva etc.) que desviará do alvo. Ou então se este for retirado antes de ser atingido.

Explana, outrossim, Edmir Netto de Araújo ${ }^{444}$, que o mesmo ocorre com o ato administrativo, ou seja,

[...] se há, em potencial, um interesse público concreto a ser cumprido, se o motivo, adequadamente considerado, está a ele voltado, se foram cumpridos

\footnotetext{
440 CRETELLA JUNIOR, José. Direito Administrativo Brasileiro. v. I Rio de Janeiro: Forense, 1983, p. 307-308.

441 ARAÚJO, Edmir Netto de. Curso de Direito Administrativo. 5. ed. São Paulo: Saraiva, 2010. p. 498.

442 ARAÚJO, Edmir Netto de. Curso de Direito Administrativo. 5. ed. São Paulo: Saraiva, 2010. p. 498.

443 ARAÚJO, Edmir Netto de. Convalidação do ato administrativo. São Paulo: Editora Ltr, 1999. p. 92.

444 ARAÚJO, Edmir Netto de. Convalidação do ato administrativo. São Paulo: Editora Ltr, 1999. p. 93.
} 
os pressupostos, se o agente competente declarou validamente a vontade do Estado sobre objeto voltado a atingir aquele resultado, na forma que o ordenamento prevê para esse resultado, se incidem os fatores de eficácia, não há como não se atingir, como resultado, a finalidade objetivada. A não ser por erro quanto à valoração desse interesse ou se o "alvo" for retirado: interesse público deixar de existir, ou de ser válido.

Em conclusão, aponta o administrativista ${ }^{445}$, “[...] o que se estuda a título de 'vícios de finalidade' é, na verdade, constatação de vícios do ato administrativo em geral, mas através do estudo da finalidade, pois não ocorre vício no resultado, o resultado é que será, por repercussão, viciado". Portanto, nesse sentido, a partir dessas constatações, vale ressaltar que o estudo da finalidade do ato pode se tornar um indicativo da ocorrência de vícios atinentes aos demais requisitos do ato administrativo (sujeito, forma, objeto, motivo), uma vez que, por ser o resultado do ato administrativo, aparece de forma mais nítida ao intérprete observador.

$\mathrm{O}$ estudo do vício da finalidade do ato administrativo foi desenvolvido no âmbito da teoria do desvio de poder. Essa expressão evoluiu a partir da doutrina francesa do detournement de pouvoir ${ }^{446}$, bem como da teoria produzida pelos italianos sob o nome de sviamento di potere como espécie de eccesso di potere ${ }^{447}$. No Brasil, encontrou campo fértil na obra de José Cretella Junior ${ }^{448}$, hoje referência no estudo deste tema.

Edmir Netto de Araújo ${ }^{449}$ afirma que "É mais fácil, ainda uma vez, a constatação do desvio de poder nos atos motivados, pela possibilidade de confronto com o motivo explicitado". Mas adverte ${ }^{450}$ que nos casos de atos motivados, com os respectivos motivos explicitados, pode se "esconder" um vício de finalidade por trás de uma atuação aparentemente legal do agente público, isto é, quando “[...] a verdadeira intenção do agente ímprobo se esconde sob uma capa de legalidade, sob a menção da existência de um interesse público forjado formalmente, sob condições aparentes de regularidade e legitimidade em não raro, buscando deixar em evidência um suposto altruísmo e ‘espírito público’ do agente”.

\footnotetext{
445 ARAÚJO, Edmir Netto de. Convalidação do ato administrativo. São Paulo: Editora Ltr, 1999. p. 93.

446 Vide: WALINE, Marcel. Dorit Administratif. Paris: Lib. Rec. Sirey, 1963.

447 Vide: FRAGOLA, Umberto. Gli atti amministrativ. Torino: UTET, 1952.

448 Vide: CRETELLA JUNIOR, José. Anulação do ato administrativo por desvio de poder. Rio de Janeiro: Forense, 1978; CRETELLA JUNIOR, José. Do desvio de poder. São Paulo: RT, 1964; CRETELLA JUNIOR, José. Sintomas denunciadores do desvio de poder. In: Revista da Procuradoria Geral do Estado. São Paulo. vol. 9, 1976.
}

449 ARAÚJO, Edmir Netto de. Convalidação do ato administrativo. São Paulo: Editora Ltr, 1999. p. 94.

ARAÚJO, Edmir Netto de. Convalidação do ato administrativo. São Paulo: Editora Ltr, 1999. p. 94. 
Para José Cretella Junior ${ }^{451}$, a configuração do desvio de poder exige a presença de quatro elementos: autoridade administrativa, competência, uso do respectivo poder e finalidade diversa da conferida pela lei. Segundo Jèze ${ }^{452}$, a violação da finalidade se constata quando o agente público persegue um fim: "1) proibido em lei; 2) de interesse geral, mas que não é de sua competência; 3) de interesse geral e lícito, e ainda dentro de sua competência, mas por meios jurídicos ineptos, segundo a lei, para obter tal resultado; 4) que não é (o fim) de interesse geral".

Cabe o registro aqui de que, mesmo em se tratando de atos imotivados, é possível verificar a ocorrência de vício de finalidade, sendo que há um agravamento no desafio em se constatar esse vício, considerando a falta dos chamados "rastros da ilegalidade", concretizados no ato motivado, por exemplo, pela presença dos motivos explicitados. Essa tarefa em se criar mecanismos de controle da finalidade dos atos administrativos, em relação ao interesse público, possibilitou o desenvolvimento de uma teoria em que se busca a investigação dos vícios de finalidade por intermédio da análise dos sintomas e indícios que denunciam a ocorrência do desvio do poder dos atos administrativos, de uma forma geral.

Nesse diapasão, invoca-se o magistério de José Cretella Júnior ${ }^{453}$ que, através de pesquisa doutrinária e jurisprudencial, nos remete ao estudo dos sintomas denunciadores do desvio de poder, reunindo em um rol enumerativo as situações nas quais se pode verificar referido vício. Dentre essas ocorrências, cabe citar:

a) Contradição do ato com atos posteriores ou anteriores da autoridade [...]; b) Motivação exagerada ou excessiva [...]; c) Alteração propositada dos fatos inspiradores da medida [...]; d) Ilogicidade manifesta dos motivos em relação ao objeto ou à própria finalidade declarada [...]; e) Manifesta injustiça da medida [...]; f) Derrogação de norma interna [...]; g) Urgência injustificada e precipitação na edição do ato, inexistência dos motivos alegados [...].

Por derradeiro, oportuno assinalar que se optou por reunir esses breves conceitos e noções sobre os vícios referentes ao objeto, ao motivo e à finalidade do ato administrativo no mesmo item, em face da inegável interdependência que decorre da análise desses elementos. Afirma, neste sentido, Edmir Netto de Araújo ${ }^{454}$, que “[...] motivo e finalidade nada mais são que faces diferentes da mesma moeda, que é o interesse público concretamente existente, e

\footnotetext{
451 CRETELlA JUNIOR, José. Controle Jurisdicional do Ato Administrativo. São Paulo : Forense, 1992. p. 273.

452 JÈZE, Gaston. Les príncipes géneraux du droit administratif. 3. ed. Paris: Giard e Briére, 1925 a 1936. p. 239.

453 CRETELLA JUNIOR, José. Sintomas denunciadores do desvio de poder. In: Revista da Procuradoria Geral do Estado. São Paulo. vol. 9, 1976. p. 27-44.

454

ARAÚJO, Edmir Netto de. Convalidação do ato administrativo. São Paulo: Editora Ltr, 1999. p. 89.
} 
por isso já dissemos algumas vezes que devem ser simétricos o interesse público, o motivo, o objeto da declaração e a finalidade, articulando-se".

Relevante, ainda, o magistério de Sergio Ferraz e Adilson Abreu Dallari ${ }^{455}$, no que tange à análise dos vícios referentes ao objeto, motivo e finalidade do ato processual, ponderando:

\begin{abstract}
A partir desse elenco legal, faremos desde já uma ponderação diretamente conectada à natureza e à finalidade do processo administrativo. Assim é que, aqui, os vícios referentes ao objeto, ao motivo e à finalidade, por isso que dizem com a própria atividade nuclear do processo - a decisão -, têm sedes próprias para reexame (recurso e revisão), descabendo à Administração-juiz desconstituir os atos assim viciados, em atuação de autotutela. Admiti-lo seria jogar por terra a própria ideia de processo, i. e., curso em frente. Findo, porém, o processo, a autoanulação poderá ocorrer, respeitados os marcos decadenciais da Lei 9.784/99.
\end{abstract}

Concordamos, em certa medida, com essa posição. Realmente, não caberia a realização da autotutela administrativa sob os elementos referentes ao objeto, motivo e finalidade do ato processual, considerando um processo ainda em tramitação perante a Administração, isto é, sem uma decisão administrativa definitiva para analisar a existência dos seus próprios vícios.

No entanto, não quer dizer que é juridicamente impossível essa possibilidade, até porque não há lei que proíba a atuação da Administração, em autotutela, com o fim de anular ato administrativo processual ou processo administrativo ainda em trâmite, em decorrência de vícios ligados ao objeto de algum ato processual de forma isolada, bem como motivo e finalidade, de certa forma, já aparentes antes da decisão final do processo.

Aconselhável, pois, a nosso ver, que se realize, se assim tiver de ser feito, a eventual anulação do processo administrativo, depois de terminado, isto é, com todo o seu percurso efetuado em definitivo, com o objeto declarado, o motivo explicitado e a finalidade atingida. Poder-se-á, pois, proceder à apuração da legalidade desses elementos processuais em destaque, quais sejam, objeto, motivo e finalidade, e verificar se estão alinhados ou não com o ordenamento jurídico em vigor.

Desta forma, realizando a transposição das noções dos vícios referentes ao objeto, motivo e finalidade do ato administrativo para o processo administrativo, pode-se afirmar que os vícios que tocam o objeto do ato administrativo, que redundam em objeto ilícito, impossível ou indeterminado, bem como os vícios que incidem sobre os motivos do ato 
administrativo, em que se constata a inexistência de motivo ou a inadequação jurídica deste para o resultado concreto da ação administrativa, ou os vícios que tangenciam a finalidade do ato administrativo, quando se opera o denominado desvio de poder, também podem ser identificados no ato administrativo processual, sendo que, em regra, redundarão em nulidade absoluta do processo administrativo.

Cabe, a esse passo, o registro atinente à legislação de regência do processo administrativo, tanto de caráter geral, como de cunho disciplinar (nas esferas da União, do Estado de São Paulo e do Município de São Paulo), enunciam algumas regras referentes ao objeto, ao motivo e à finalidade. Isto em relação aos atos administrativos considerados isoladamente, quanto em uma perspectiva processual.

Vale ressaltar, por mais desta vez, que a finalidade do processo administrativo, em clima de Estado de Direito, como o nosso, é garantir maior eficiência à atuação administrativa, bem como disponibilizar para o administrado meios mais seguros e consagradores dos direitos fundamentais previstos em nossa Constituição Federal de 1988.

Essa finalidade, em síntese, é aquela mais genérica, ligada a toda atuação estatal sob a forma processual, sem, contudo, levar em consideração a modalidade do processo administrativo, nosso enfoque, seja geral ou disciplinar. Nesse particular contexto a finalidade comparece de modo mais específico e compete à Administração persegui-la, o que terá influência sobre os elementos referentes ao objeto e ao motivo do ato administrativo.

Vejamos um exemplo que se mostra relevante, uma vez que reincidente nas alegações de nulidade, principalmente no tocante ao motivo do ato administrativo processual. Aborda a desproporcionalidade da pena disciplinar aplicada, matéria que se vincula, preponderantemente, ao vício de motivo do ato administrativo processual, e determina:

PROCESSO ADMINISTRATIVO DISCIPLINAR. DEMISSÃO. DESPROPORCIONALIDADE. A comissão do processo administrativo disciplinar concluiu que o impetrante praticou a infração prevista no art. 117, IX, da Lei n. 8.112/1990 c/c o art. 10, I, da Lei n. 8.429/1992. Recomendou sua demissão em razão de ele ter exercido influência na contratação de determinada sociedade empresarial com inexigibilidade de licitação, tendo sido alocados recursos públicos para o pagamento dos serviços por ela prestados. Porém não foi o impetrante quem celebrou o contrato, nem foi o responsável pela liberação dos recursos públicos. Servidores acusados da prática de infrações disciplinares menos graves não sofreram sanção devido ao reconhecimento da prescrição. Assim, vê-se que, ao prevalecer a pena de demissão, a conduta do impetrante é tida por mais relevante do que a daqueles outros servidores responsáveis pela contratação e liberação dos recursos. Diante disso, é necessário decretar a nulidade da pena de demissão aplicada com violação dos princípios da isonomia, da razoabilidade, da proporcionalidade, da individualização da pena, da necessidade de 
motivação dos atos administrativos, com o desiderato de que outra seja aplicada, ao considerar o grau de envolvimento do impetrante, o fato de não obter proveito para si ou para terceiro em detrimento de sua função pública, as atenuantes relativas ao tempo de serviço público, a ausência de anterior punição funcional, bem como a capitulação das condutas dos demais participantes. MS 11.124 - DF, Rel.Min. Nilson Naves, julgado em 26/9/2007.

Mais ainda, mister colacionar importante julgado que trata do vício de desvio de finalidade, no bojo de processo administrativo disciplinar:

PAD. PARCIALIDADE. AUTORIDADE JULGADORA. NULIDADE. Tratase de mandado de segurança contra ato de ministro de Estado que culminou na demissão do impetrante do cargo de técnico administrativo do Ibama com base nos arts. 136 e 137, parágrafo único, da Lei n. 8.112/1990, por valer-se do cargo para lograr proveito pessoal ou de outrem em detrimento da dignidade da função pública, receber propina, comissão, presente ou vantagem de qualquer espécie e por improbidade administrativa. Alega a impetração vícios formais no processo administrativo disciplinar (PAD), notadamente a parcialidade da autoridade julgadora ao concluir pela pena de demissão, uma vez que teria interesse na exclusão do servidor. In casu, o impetrante foi absolvido das acusações no primeiro processo administrativo, contudo todo o feito foi anulado. Ressalte-se que o referido PAD foi instaurado em decorrência de denúncias feitas pela mesma autoridade que depois veio a aplicar a pena de demissão ao impetrante, visto que, quando da realização do segundo PAD, já se encontrava como titular da pasta do meio ambiente. Diante disso, a Seção concedeu a segurança ao entendimento de que, a despeito das alegações de que a autoridade agiu com imparcialidade ao editar a portaria de demissão, os fatos demonstram, no mínimo, a existência de impedimento direto da autoridade julgadora no $P A D$, e suas manifestações evidenciaram seu interesse no resultado do julgamento. Assim, demonstrado o interesse da referida autoridade na condução do processo administrativo e no seu resultado, seja interesse direto seja indireto, o fato de o denunciante ter julgado os denunciados, entre os quais o impetrante, configura uma ofensa não somente ao princípio da imparcialidade, mas também da moralidade e da razoabilidade e configura, ainda, o desvio de finalidade do ato administrativo que, na hipótese, parece atender mais ao interesse pessoal que ao público, caracterizando vício insanável no ato administrativo objeto da impetração. Precedente citado: MS 14.958-DF, DJe 15/6/2010. MS 14.959-DF, Rel. Min. Haroldo Rodrigues (Desembargador convocado do TJ-CE), julgado em 23/2/2011. 


\subsection{EFEITOS DA DECLARAÇÃO DE NULIDADE NO PROCESSO ADMINISTRATIVO}

A Administração deve respaldar suas ações sempre em consonância à lei que, por sua vez, abrange o interesse público. Destarte, na medida em que a Administração se afasta dos ditames da legalidade, operando sem a força obrigatória do ato administrativo legal, fatalmente estar-se-á diante de uma nulidade a ser declarada em seu âmbito.

Ressalta-se que a operação pela qual se procede a declaração da ilegalidade no Direito Administrativo é denominada de invalidação, calcada no princípio da autotutela da Administração, cujos parâmetros estão sedimentados nas Súmulas STF 346 e 473.

Ainda que transcritas e comentadas na primeira parte da presente dissertação, merecem nova menção as célebres Súmulas 473 e 346 expedidas pelo nosso Excelso Pretório. Rezam tais textos normativos:

STF Súmula $n^{0} 473$ - A administração pode anular seus próprios atos, quando eivados de vícios que os tornam ilegais, porque deles não se originam direitos; ou revogá-los, por motivo de conveniência ou oportunidade, respeitados os direitos adquiridos, e ressalvada, em todos os casos, a apreciação judicial;

STF Súmula no 346 - A administração pública pode declarar a nulidade dos seus próprios atos.

Ressalta à evidência que a Administração detém o poder de revogar um ato administrativo, de acordo com critérios de oportunidade e conveniência. O instituto coloca o analista diante de um ato administrativo legal, existente e válido, o qual, no entanto, pela inoportunidade e inconveniência ao interesse público, deixa de surtir seus efeitos uma vez revogado. A essa operação denomina-se revogação do ato administrativo, atividade privativa da Administração.

Invalidação e revogação do ato administrativo são espécies do gênero desfazimento do ato administrativo. Segundo a doutrina encampada por Edmir Netto de Araújo ${ }^{456}$, "Essa atividade da Administração, quer nos casos de constatação de ilegalidade, 
quer nos de reavaliação do mérito, é designada por alguns autores brasileiros como 'retirada' ou 'extinção' ${ }^{457}$, por outros, como 'desfazimento" 458 do ato administrativo [...]".

Diferentemente da revogação do ato administrativo, que é atividade privativa da Administração ${ }^{459}$, a invalidação, em decorrência da nulidade pode ser realizada tanto por via do controle externo, através do Poder Judiciário e do Poder Legislativo, ou pelos Tribunais de Contas, quanto pelo controle interno, realizado pela própria Administração.

No que toca ao controle externo, a legislação se oferece clara, atribuindo esta competência ao Poder Judiciário e ao Poder Legislativo, atuando este com o auxílio dos Tribunais de Contas. Todos podem aferir a legalidade dos atos administrativos na medida de suas competências.

Com propriedade, explicita Edmir Netto de Araújo ${ }^{460}$ :

[...] o controle externo do Estado, uma vez que significa aquele exercido, nos termos constitucionais, por outro Poder, diverso daquele que é controlado, abrange também, além do controle parlamentar direto (pelo poder Legislativo) e do exercido pelos Tribunais de Contas (que são órgãos auxiliares do Poder Legislativo), também o controle jurisdicional, pelo Poder Judiciário.

O controle interno, fundamentado pelo princípio da autotutela da Administração, é exercido pela Administração e direcionado tanto para os entes da Administração Direta quanto Indireta, de acordo com doutrina de Edmir Netto de Araújo ${ }^{461}{ }^{462}$ : "Em resumo, o controle interno sobre qualquer entidade da Administração se exerce por hierarquia (dentro da própria pessoa jurídica), por tutela (do executivo sobre entidade da Administração Indireta ou

457 Conforme Celso Antônio Bandeira de Mello, vide: BANDEIRA DE MELLO, Celso Antônio. Curso de Direito Administrativo. 29. ed. São Paulo: Malheiros, 2012. p. 454; e Maria Sylvia Zanella Di Pietro, vide: DI PIETRO, Maria Sylvia Zanella. Direito Administrativo. 25. ed. São Paulo: Atlas, 2011. p.242.

458 Conforme José Cretella Junior, vide: CRETELLA JUNIOR, José. Controle Jurisdicional do Ato Administrativo. Rio de Janeiro: Forense, 1992. p. 304.

459 “[...] a competência para desfazer atos válidos por razões de oportunidade ou conveniência é exclusiva ou privativa da Administração, porque é desta a valoração interna que configura o mérito do ato administrativo. $\mathrm{O}$ princípio da separação dos poderes (art. $2^{\circ} \mathrm{CF}$ ) é que fundamenta essa exclusividade" (ARAÚJO, Edmir Netto de. Curso de Direito Administrativo. 5. ed. São Paulo: Saraiva, 2010. p. 500).

460 ARAÚJO, Edmir Netto de. Curso de Direito Administrativo. 5. ed. São Paulo: Saraiva, 2010. p. 1202.

461 ARAÚJO, Edmir Netto de. Curso de Direito Administrativo. 5. ed. São Paulo: Saraiva, 2010. p. 1184.

462 Complementa o administrativista, explicitando os mecanismos e meios de controle interno por hierarquia de que se utiliza a Administração para exercer a autotutela, citando: “a) Princípio da autotutela ...; b) Avocação. Revogação. Anulação [...] ; c) Recurso administrativo hierárquico. Pedido de reconsideração. Revisão [...] d) Recursos nas leis de procedimento administrativo, [...] e) Representação. Reclamação administrativa [...] f) Direito de Petição [...] ; g) Prescrição e decadência [..]; h) Abuso, desvio ou excesso de poder [...];" (ARAÚJO, Edmir Netto de. Curso de Direito Administrativo. 5. ed. São Paulo: Saraiva, 2010. p. 1184-1196. 
descentralizada), fundado na autotutela administrativa (poder de revisão de seus próprios atos)".

Destarte, mediante as operações e mecanismos de controle supraenunciados e diante de uma ilegalidade constatada, deve a Administração recompor a legalidade de sua atuação, conformando-se ao Estado de Direito. Dessa noção inicial, partimos para a questão central do presente item, isto é, quais os efeitos da declaração de nulidade absoluta do ato administrativo processual?

Ressalta-se que o ato administrativo existente e válido está apto a produzir os seus efeitos. Em sede processual, no âmbito da Administração pública, não é diferente. Tanto o ato processual quanto o processo administrativo, desde que existentes e válidos, produzem os resultados perseguidos; daí emanam efeitos tanto práticos quanto jurídicos.

Quando se depara com uma nulidade absoluta, no seio do processo administrativo, a preocupação será indigitar os efeitos de respectiva declaração de ilegalidade, quer realizada por via de controle externo, quer pelo controle interno? A essa resposta, como já assinalado, emerge a regra para a nulidade absoluta que conduz à anulação ou do ato processual, se em curso o processo, ou do processo administrativo, caso este já se encontre encerrado, retroagindo os efeitos à edição do ato declarado ilegal.

Por óbvio, toda regra comporta exceção e aqui não poderia ser diferente. Convém recordar que a declaração de ilegalidade do ato processual administrativo ou do processo administrativo inquinado de nulidade absoluta deve ter como norte, além da legalidade administrativa, os princípios gerais do Direito, tais como a boa-fé e a segurança jurídica.

Ora, a atuação da Administração, seja processual ou não, encontra-se eivada de atributos que se concretizam por intermédio da edição dos atos administrativos. Assim, não há que ignorar a qualidade de autoexecutoriedade, a imperatividade e a presunção de legitimidade, que, por exemplo, envolvem a atividade da Administração. Assim, no momento da edição do ato, sob a tutela dessas qualidades, a perspectiva é a de que ele seja "saudável", isto é, não possua vício que o torne imprestável, fazendo jus, pois, do ponto de vista dos destinatários do ato administrativo, à expectativa de legalidade da atuação da Administração.

É dizer que, até que se declare que um ato administrativo perfeito contenha vício, isto é, afigure-se defeituoso e ilegal, deve este ser considerado legal e, por isso, apto para produzir seus efeitos. Dotado de eficácia. Por isso é que Edmir Netto de Araújo ${ }^{463}$, na perspectiva dos efeitos dos atos administrativos, afirma: 
Eficácia, portanto, é a qualidade que adquire o ato existente e válido (perfeito), através da incidência de certos fatores, que transformam sua aptidão para produzir os efeitos jurídicos objetivados na efetiva produção desses efeitos: o ato perfeito, mas ineficaz pode, momentos após, tornar-se eficaz.

E quais seriam esses efeitos produzidos pelos atos até então considerados perfeitos? Duas as ordens quanto aos efeitos dos atos administrativos, consoante explica Antônio Carlos Cintra do Amaral ${ }^{464}$ : "Sob o título de eficácia do ato administrativo, há que se distinguir: a) eficácia jurídica; b) eficácia fática”.

Atribuindo relevância maior à eficácia jurídica, assim se manifesta o administrativista $^{465}$ :

$\mathrm{O}$ ato administrativo é uma norma jurídica. Como tal opera efeitos no mundo jurídico. Não nos parece, porém, que tais efeitos constituam algo dissociável logicamente do próprio ato (norma). Por ser norma jurídica, o ato administrativo já opera, com sua existência, uma modificação no mundo jurídico. Há, porém, um outro efeito jurídico, decorrente de ser ele uma norma concreta, qual seja, o de constituir, modificar ou extinguir uma relação jurídica entre Estado e particular. [...] Quanto aos efeitos fáticos, finalmente, são eles menos relevantes para o estudo do ato administrativo. Entendemos que o ato administrativo (norma jurídica) permanece válido mesmo quando (de fato) ineficaz.

Jacintho de Arruda Câmara ${ }^{466}$ abordando o assunto, passa a explanar os efeitos jurídicos e fáticos do ato administrativo, promovendo o seguinte registro:

$\mathrm{O}$ ato passa a ser detentor de eficácia jurídica a partir do momento em que emana uma ordem imediatamente vinculante: deve ser " $x$ " e com isso cria uma relação jurídica. Esta ordem pode outorgar um direito, pode extingui-lo; pode estipular uma proibição; para resumir tudo numa só palavra: constitui uma relação jurídica. Isso tudo, repita-se, no plano normativo. A eficácia fática diz respeito à repercussão que o mandamento provoca no ambiente social no qual está inserido (eficácia social). $\mathrm{O}$ ato ganha eficácia fática quando são produzidos fatos para dar cumprimento à ordem nele estabelecida (eficácia jurídica).

No bojo do processo administrativo não é diferente. Verificam-se, certamente, ambos os efeitos jurídicos e os fáticos oriundos de um ato processual e, principalmente, da própria decisão administrativa, de modo que somente a partir da declaração de ilegalidade do respectivo ato processual ou da decisão administrativa surge ao ente declarador da ilegalidade

\footnotetext{
464 AMARAL, Antônio Carlos Cintra do. Extinção do Ato administrativo. São Paulo: RT, 1978. p. 32-36.

465 AMARAL, Antônio Carlos Cintra do. Extinção do Ato administrativo. São Paulo: RT, 1978. p. 32-36.

466 CÂMARA, Jacinto de Arruda. A preservação dos efeitos dos atos administrativos viciados. In: Estudos de Direito Administrativo em homenagem ao Prof. Celso Antônio Bandeira de Mello. São Paulo: Max Limonad, 1996. p. 55.
} 
o desafio de optar pelo modo de operacionalizar a manifestação invalidadora do ato processual ilegal, bem como lidar com os seus respectivos efeitos.

Nessa perspectiva, a partir da declaração da nulidade absoluta de um ato administrativo processual, principalmente, da decisão administrativa definitiva, com a consequente retroatividade de seus efeitos para alcançar o momento da edição do ato/decisão eivado de nulidade absoluta (operando ex tunc), consideram-se desconstitutivos os efeitos jurídicos; poderão, no entanto, ocorrer efeitos fáticos, oriundos do ato declarado nulo, e serem mantidos esses efeitos em decorrência dos princípios gerais de direito consistentes na segurança jurídica e na boa-fé. A própria impossibilidade de se desconstituir alguns efeitos fáticos já consolidados e irreversíveis, importa sua conservação. A respeito, pronuncia-se José Cretella Neto ${ }^{467}$, "Os princípios gerais do Direito têm por objeto fornecer ao julgador meios para a solução jurídica dos litígios que lhe são submetidos, em caso de silêncio do direito costumeiro ou convencional”.

Nesta esteira, o princípio da segurança jurídica consiste em um valor presente em quaisquer ordens jurídicas e se traduz em valores como justiça, estabilidade, segurança, legalidade, entre outros. Jacintho de Arruda Câmara ${ }^{468}$ assim se manifesta sobre o axioma em destaque:

Não se afirma com isso que a segurança jurídica seja um princípio suprajurídico, um princípio de direito natural. Não é isso que se quer dizer. Acontece que a própria "razão de ser" do direito vincula-se à ideia de segurança. É por propiciar segurança - estabilizando as relações sociais qualificadas como juridicamente relevantes - que o Direito se faz imprescindível na vida do homem em sociedade.

Embora o princípio da segurança jurídica possa ser invocado em prol da manutenção dos efeitos fáticos dos atos processuais administrativos ou das decisões administrativas acometidas pela nulidade absoluta, e, portanto, declaradas nulas, referido axioma é invocado, em especial, com referência aos atos administrativos processuais anuláveis, onde procuram-se conservar os efeitos tanto jurídicos quanto fáticos. Essa é a posição de Sergio Ferraz e Adilson Abreu Dallari ${ }^{469}$, “O princípio da segurança jurídica ou da estabilidade das relações jurídicas impede a desconstituição injustificada de atos ou situações

\footnotetext{
467 NETO, José Cretella. Fundamentos principiológicos do processo civil. Rio de Janeiro: Forense, 2002. p. 18.

468 CÂMARA, Jacinto de Arruda. A preservação dos efeitos dos atos administrativos viciados. In: Estudos de Direito Administrativo em homenagem ao Prof. Celso Antônio Bandeira de Mello. São Paulo: Max Limonad, 1996. p. 65. 
jurídicas, mesmo que tenha ocorrido alguma inconformidade com o texto legal durante sua constituição".

Edmir Netto de Araújo $^{470}$ assim se posiciona com relação ao princípio da segurança jurídica, que pode traduzir princípio geral na conservação dos valores jurídicos, e a sua vinculação aos atos anuláveis no campo do Direito Administrativo:

A doutrina que admite a anulabilidade dos atos administrativos e, em consequência, a possibilidade de sua convalidação, sustenta-se no princípio geral da conservação dos valores jurídicos, de um lado, e de outro, no poderdever que a Administração tem de rever seus próprios atos, para assegurar sua conformação com a ordem jurídica, que é o princípio da autotutela.

De sua parte, o princípio da boa-fé merece destaque no que se refere à questão da manutenção dos efeitos fáticos de um ato processual ou decisão administrativa declarada nula. É que, em configurando atributo que se vincula à própria intenção do sujeito, a sua constatação ou não irá influenciar diretamente na manutenção dos efeitos dos atos processuais que já atingiram os sujeitos do processo administrativo, sobretudo nos processos ampliativos de direitos, como por exemplo, concessão de aposentadoria.

Trata-se de princípio geral do direito e, como asseveram Sergio Ferraz e Adilson Abreu Dallari $^{471}$,

A boa-fé não é elemento ou circunstância a ser considerada apenas no que diz respeito às relações de direito privado, entre particulares, ou de direito penal; a consideração da boa ou má-fé, tanto do particular que se relaciona com a administração Pública quanto do agente público que se relaciona com o administrado é também essencial, configurando, sim, um princípio também de direito administrativo.

Em suma, na esfera do processo administrativo, apontam os autores ${ }^{472}$ :

[...], no tocante à decisão de validar ou invalidar um ato, de manter ou desconstituir uma situação jurídica, de aplicar ou não uma penalidade, a boafé do particular envolvido deve ser levada em consideração, pois sua intenção é efetivamente relevante para o Direito. Essa relevância está expressamente ressaltada no art. ${ }^{\circ}$, IV, da Lei 9784/99, de 1999, e reiterada em seu artigo $4^{\circ}$, II.

Compete assinalar, também, que há situações em que, independente da aplicação dos princípios gerais de direito, os efeitos fáticos de um ato administrativo, devidamente

\footnotetext{
470 ARAÚJO, Edmir Netto de. Convalidação do ato administrativo. São Paulo: Editora Ltr, 1999. p. 69.

471 FERRAZ, Sérgio; DALLARI, Adilson Abreu. Processo Administrativo. São Paulo: Malheiros, 2001. p. 81.

472 FERRAZ, Sérgio. DALLARI, Adilson Abreu. Processo Administrativo. São Paulo: Malheiros, 2001. p. 83.
} 
consumado, se tornem irreversíveis, como por exemplo, a demolição de um prédio, cujo processo de demolição tenha sido atingido pela nulidade absoluta ou que tenha culminado com uma decisão denegatória. Como reconstituir esse prédio? Pode-se declarar nulo o ato, seu conteúdo normativo (efeito jurídico), mas os efeitos fáticos restam impossíveis de serem alterados, pois que imutáveis.

Destarte, quando nos deparamos com um ato processual administrativo que contenha nulidade absoluta no âmbito do processo administrativo, a regra é declaração da nulidade com efeitos ex tunc, extirpando-se quaisquer efeitos que tenham decorrido do ato viciado, tanto jurídicos, quanto fáticos. Pode ocorrer, contudo, mesmo com a declaração de nulidade absoluta do ato administrativo processual, a prevalência de alguns efeitos fáticos, considerando, além da impossibilidade de alteração dos efeitos fáticos, também, e, principalmente, os princípios gerais do direito consistentes pelo binômio da segurança jurídica e da boa-fé, que deverão ser analisados juntamente com os valores normativos decorrentes do interesse público e a da legalidade.

\subsection{LIMITES DA DECLARAÇÃO DE NULIDADE NO PROCESSO ADMINISTRATIVO}

A atuação da Administração, por intermédio do princípio da autotutela, consagrado na Súmula STF ${ }^{\circ}$ 473, com a finalidade de declarar a nulidade de um ato administrativo, quer em contexto processual, quer não, deve se conformar aos cânones de comando do Estado de Direito preconizado pela Constituição Federal de 1988.

Impõe-se, por via de consequência, a observância do princípio do devido processo legal e de suas garantias de direito material e processual, conforme apontamentos anteriores, competindo-lhe, outrossim, o respeito aos princípios da ampla defesa e do contraditório, sobretudo com relação àqueles sujeitos que serão atingidos pelo ato administrativo invalidador.

Essa linha vem acolhida pela lei de regência do processo administrativo no Estado de São Paulo, Lei n ${ }^{\circ}$ 10.177/98, diploma que, em seus artigos 57 a 61, prevê um procedimento específico para invalidação de atos e contratos administrativos. 
Mônica Martins Toscanos Simões ${ }^{473}$ assim se manifesta sobre o tema:

Em suma, quanto ao limite formal tem-se que o exercício da autotutela deve ocorrer através de procedimento administrativo que confira àqueles, que eventualmente venham a ser atingidos pela decisão invalidatória, oportunidade de manifestação prévia, observados os desdobramentos da ampla defesa. Essa providência é indispensável ao resguardo do standard do devido processo legal, sem o que não se pode falar em legítima recomposição da legalidade.

Em um contexto processual, encontrando-se ainda em tramitação o processo administrativo, deve-se buscar refazer o ato administrativo declarado nulo e todos os atos subsequentes ao referido ato acometido pela ilegalidade insanável, respeitando-se, por certo, os parâmetros do devido processo legal, ampla defesa e contraditório. Se findo o processo, porém, a anulação deve atingi-lo na sua íntegra, por completo, em razão de ter sido acometido pela nulidade absoluta, sendo recomendável e oportuno que se proceda à instauração de um novo processo administrativo, também respeitando-se os parâmetros do devido processo legal, ampla defesa e contraditório.

Ademais, acrescente-se que, além de resguardar o devido processo legal, de acordo com Mônica Martins Toscanos Simões ${ }^{474}$,

[...] deve a Administração observar todas as normas jurídicas pertinentes, zelando pela regularidade do procedimento em seu aspecto substancial. A rígida observância, ao longo do procedimento administrativo invalidador, da principiologia administrativa e das regras jurídicas pertinentes constitui o chamado limite material da autotutela administrativa.

Dessa forma, não basta, somente, a garantia formal do devido processo legal, da ampla defesa e do contraditório; impositivo se apresenta firmar a validade do novo ato processual, através da observação de todas as regras e princípios que regem o Direito Administrativo e o processo administrativo, garantindo-se que se realize uma atividade administrativa restauradora da legalidade, isenta de vícios, isto é, válida, realizada por agente capaz e competente, com observância das formas e formalidades essenciais, sem desvios ou ilicitudes que acometam o objeto, a finalidade e o motivo da atuação estatal reparadora.

\footnotetext{
473 SIMÕES, Mônica Martins Toscano. O Processo Administrativo e a Invalidação de Atos Viciados. São Paulo: Malheiros, 2004. p. 163.

474 SIMÕES, Mônica Martins Toscano. O Processo Administrativo e a Invalidação de Atos Viciados. São Paulo: Malheiros, 2004. p. 163.
} 
Cabe também mencionar aspectos referentes à limitação temporal para que se efetue a invalidação do ato administrativo processual. Edmir Netto de Araújo ${ }^{475}$ introduz o tema referente ao decurso do tempo, anotando que este

[...] influi de muitas maneiras nas relações jurídicas: em decorrência dele, adquirem-se direitos, extinguem-se direitos, cumprem-se punições e às vezes, sem perder o direito, perde-se a possibilidade de operacionalizá-lo através dos meios próprios: isto acontece, também, com a Administração em relação ao exercício do poder de rever os próprios atos, por ilegalidade ou inconveniência, e do dever de corrigir as ilegalidades de seus atos.

Na peculiar esfera do Direito Administrativo, conclui o mestre que ${ }^{476}$ :

As leis administrativas, por sua vez, estabelecem prazos que superados, impedem a Administração de rever seus próprios atos, ou seja anulá-los quando a nulidade é absoluta, ou optar entre anulação e convalidação no caso das nulidades relativas. É a prescrição interna, ou administrativa, que faz desaparecer o direito de correção de tais atos, seja por provocação, seja "ex officio" pela Administração, porque os seus efeitos já se estabilizaram.

Ademais, o fundamento da prescrição administrativa, como anotado por Edmir Netto de Araújo ${ }^{477}$,

[...] reside no princípio da conservação dos valores jurídicos já concretizados, desta feita para impedir, em razão do decurso do prazo legalmente fixado, o exercício da autotutela pela Administração; também aqui incide o objetivo da estabilidade das relações jurídicas, muito mais justificável até no caso dos atos administrativos, que são dotados de imperatividade, autoexecutoriedade e presunção de legitimidade.

Interessante verificar, nesta esteira, a posição legal, mormente os textos normativos que disciplinam os processos administrativos no âmbito da União e no âmbito do Estado de São Paulo. Assim, em área federal, inequívoca se afigura a prescrição contida no artigo 114, da Lei $\mathrm{n}^{\mathrm{o}}$ 8.112/90, ao prever o dever da Administração de, a qualquer tempo, rever seus atos eivados de ilegalidade. Para parte da doutrina, contudo, o preceito não pode ser interpretado de forma literal.

É que não há espaço em nosso ordenamento jurídico, onde vige o Estado Democrático de Direito, para inexistência de um prazo para limitar a atuação do Estado em rever seus próprios atos eivados ou não por ilegalidade. Caso assim fosse, não se estaria consagrando a segurança jurídica e próprio princípio da legalidade, de modo que qualquer

\footnotetext{
475 ARAÚJO, Edmir Netto de. Convalidação do ato administrativo. São Paulo: Editora Ltr, 1999. p. 148.

476 ARAÚJO, Edmir Netto de. Convalidação do ato administrativo. São Paulo: Editora Ltr, 1999. p. 149.

477 ARAÚJO, Edmir Netto de. Convalidação do ato administrativo. São Paulo: Editora Ltr, 1999. p. 149.
} 
regra que imponha prazos indefinidos no tempo para que se discuta um conflito, como o interesse da Administração em anular seus atos eivados de nulidade, não deve prevalecer.

Assim, merece registro o artigo 54, da Lei $n^{0}$ 9.784/99, que dispõe sobre o processo administrativo aplicável em esfera federal, em que se prevê que decai em 5 (cinco) anos, contados da data em que foram praticados, salvo comprovada má-fé, o direito da Administração de anular os atos administrativos de que decorram efeitos favoráveis para os destinatários. Já a Lei $\mathrm{n}^{0} 10.177 / 98$, reguladora do processo administrativo no âmbito do Estado de São Paulo, estabelece, no inciso I, do seu artigo 10, que a Administração anulará seus atos inválidos, de ofício ou por provocação de pessoa interessada, salvo quando ultrapassado o prazo de 10 (dez) anos contado de sua produção.

Depreende-se, pois, que o instituto que mais se conformiza à ideia da necessidade de fixar - oferecendo a dosagem - a passagem do tempo e, em razão deste transcurso do tempo, impedir a Administração de proceder à anulação atos atingidos pelo vício da nulidade é a decadência. Isso porque, além da própria Lei $n^{0}$ 9.784/99 assim preconizar, necessário reconhecer que a Administração não demanda de ação judicial para rever seus atos, haja vista o princípio da autotutela, sendo assim, o termo decadência, que alcança o próprio direito é mais apropriado, ao invés da prescrição, que, por sua vez, tem sua ligação mais íntima com a perda da ação que ampara o direito.

Desse sentir, Edmir Netto de Araújo ${ }^{478}$, quando afirma que o transcurso de tempo para Administração proceder à anulação de seus atos nulos, aproxima-se mais da noção de decadência, senão vejamos:

Doutrinariamente, entende-se que os sentidos em que a expressão prescrição administrativa são empregados compreendem a perda do prazo para recurso administrativo pelo interessado, ou o escoamento do prazo para que a administração reexamine e/ou modifique seus próprios atos (aqui sim, a noção aproxima-se da decadência) [...].

E Mônica Martins Toscanos Simões ${ }^{479}$, no que tange à consumação da decadência e prazo quinquenal previsto na Lei $\mathrm{n}^{\circ}$ 9784/99, assinala: “Assim, ultrapassado o lapso quinquenal opera-se a decadência - e nessa medida, falece à administração o 'direito' de invalidar seus atos viciados".

\footnotetext{
478 ARAÚJO, Edmir Netto de. Curso de Direito Administrativo. 5. ed. São Paulo: Saraiva, 2010. p. 1190.

479 SIMÕES, Mônica Martins Toscano. O Processo Administrativo e a Invalidação de Atos Viciados. São Paulo: Malheiros, 2004. p. 169.
} 
Importante ressaltar que, no tocante aos atos administrativos que produzam efeitos restritivos, bem como àqueles que decorram da má-fé do administrado, não se detecta previsão legal no âmbito da Lei $n^{0}$ 9.784/99; daí, interessante o entendimento de Mônica Martins Toscano Simões, no sentido de se utilizar, para a respectiva revisão via autotutela administrativa, a aplicação da hipótese prescricional de maior prazo (dez anos) prevista no Código Civil de 2002. A autora ${ }^{480}$ defende a aplicação do prazo de 10 (dez) anos, previsto pelo Novel Código Civil, aos casos não abarcadas pela mencionada Lei no 9.784/99, isto é, atos restritivos de direitos e atos eivados de má-fé do administrado. Ressalta a autora que o prazo maior, em ambas as ocasiões, viria a atender ao princípio da segurança jurídica, sendo, outrossim, em se tratando de má-fé, mais coerente e adequado.

Concordamos com a autora com relação ao caso da má-fé. Discordamos, todavia, no que tange aos atos restritivos de direitos, até porque, a nosso ver, há elementos de discrímen razoáveis para justificar a diferença de tratamento, com a aplicação de um prazo maior aos atos restritivos de direitos, eivados de nulidade, e menor com relação aos atos ampliativos de direito. Parece-nos que o prazo a ser aplicado, nesse casos, continuaria a ser aquele do artigo 54, da Lei $n^{\circ}$ 9.784/99, isto é, a prescrição quinquenal. Ademais, não há uma exclusão expressa imposta por este texto legal, a exemplo do que se verifica em relação aos atos eivados de má-fé.

Já quando não há previsão legal com relação aos prazos decadenciais para Administração anular seus atos nulos, há controvérsia considerável na doutrina de Direito Administrativo. Parte dos teóricos ${ }^{481}$ defende a negação de prazo para que se promova a invalidação do ato eivado de nulidade, isso com lastro no interesse público que a atuação administrativa deve perseguir. Também existem doutrinadores ${ }^{482}$ que, invocando a aplicação da analogia em relação à prescrição em esfera judicial, preconizada para a Administração (Decreto Federal n ${ }^{\circ}$ 20.910/32), advertem sobre um prazo de 5 (cinco) anos a ser considerado. Ainda, de se recordar doutrina ${ }^{483}$ que propõe, na ausência de uma previsão expressa para que a Administração promova a invalidação do ato eivado de nulidade, a prevalência das

\footnotetext{
480 SIMÕES, Mônica Martins Toscano. O Processo Administrativo e a Invalidação de Atos Viciados. São Paulo: Malheiros, 2004. p. 169-171.

481 OLIVEIRA, Regis Fernandes de. Ato administrativo. São Paulo: RT, 1978. p. 122.

482 MEIRELLES, Hely Lopes. Direito Administrativo Brasileiro. 33. ed. São Paulo: RT, 2007. p. 683; DI PIETRO, Maria Sylvia Zanella. Direito Administrativo. 25. ed. São Paulo: Atlas, 2012. p. 804.
}

483 BANDEIRA DE MELlo, Celso Antônio. Curso de Direito Administrativo. 29. ed. São Paulo: Malheiros, 2012. p. 1077. 
previsões do Direito privado, isto é, prazos mais curtos para atos anuláveis e mais longos para o nulos.

Por fim convém lembrar que, não havendo prazo previsto na legislação competente, no que tange à aplicação retroativa de anulação de atos eivados de nulidade, sobre estes não poderá produzir efeitos a lei nova. Esta atinge apenas atos e operações a partir da data de sua entrada em vigor. Essa é a posição de Edmir Netto de Araújo ${ }^{484}$, quanto ao entendimento da Lei n ${ }^{\circ}$ 10177/98, opinião a qual também defendemos:

[...] como a lei não se referiu expressamente a sua aplicação retroativa (o que seria até legítimo), o efeito imediato da lei nova é a partir de sua vigência, e não de fatos do passado, pois os atos e fatos pretéritos e seus efeitos realizados sob o império do preceito antigo não podem ser atingidos pelo preceito novo sem essa retroatividade expressa, a qual, salvo disposição legal em contrário, é sempre proibida, inclusive quanto a fatos pendentes.

Destarte, encampando a ideia de decadência a impedir a Administração de anular seus próprios atos, quando eivados de nulidade, nos parece que, salvo disposição expressa em contrário, por analogia, mereceria aplicação o preconizado no Decreto Federal no 20.910/32, preordenando um prazo de 5 (cinco) anos para anulação dos atos administrativos não eivados pela má-fé, e, nos casos de atos acometidos pela má-fé do administrado, adotando-se o critério de coerência e proporcionalidade, o prazo viria a se alongar para 10 (dez) anos, como o fixado pelo Novel Código Civil.

Relevante, neste particular segmento, recordar ementa de consagrada jurisprudência emanada do STF (RE 158.543 - RS), que trata da necessidade de imposição do devido processo legal, contraditório e ampla defesa, para o fim de proceder à anulação de ato eivado de vício:

EMENTA: ATO ADMINISTRATIVO - REPERCUSSÕES - PRESUNÇÃO DE LEGITIMIDADE - SITUAÇÃO CONSTITUIDA - INTERESSES CONTRAPOSTOS -ANULAÇÃO - CONTRADITÓRIO. Tratando-se da anulação de ato administrativo cuja formalização haja repercutido no campo de interesses individuais, a anulação não prescinde da observância do contraditório, ou seja, da instauração de processo administrativo que enseje a audição daqueles que terão modificada situação já alcançada. Presunção de legitimidade do ato administrativo praticado, que não pode ser afastada unilateralmente, porque e comum à Administração e ao particular. 


\section{CONCLUSÕES}

Da pesquisa efetuada, a partir de vasta literatura jurídica que albergou doutrina, jurisprudência e ensinamentos captados em aulas, palestras e conferências de ilustres mestres, ao longo do Curso de mestrado, resultou a presente dissertação com o objetivo de oferecer, de modo sistematizado, o estágio em que se encontra a teoria das nulidades em sede de processo administrativo. Reflexo da investigação, realizada em território jurídico de elevada complexidade e de acesas polêmicas, as conclusões espelham um quadro otimista, de aperfeiçoamento do Direito Administrativo, com um aporte especial incidente sobre o processo administrativo, sua vulnerabilidade perante a lesão produzida por vícios, as consequências quanto aos efeitos perversos e às técnicas de restauro, quando viáveis. Em suma, foi verificado que:

1 - A evolução do Direito Administrativo foi contemplada com influências de origem romanística e anglo-saxã, que contribuíram para o percurso evolutivo do Direito Administrativo brasileiro, inclusive sobre o instituto do processo.

2 - Entre nós, a Europa, em especial a França, a Itália e a Alemanha, países de origem romanística, com inequívoca prevalência das decisões do Conselho de Estado francês, serviu de inspiração para as linhas basilares do instituto do processo administrativo. Isto apesar de, no Brasil, em um contexto político-institucional federativo, sobretudo após a proclamação da república e com a extinção do Conselho de Estado, adotar-se a jurisdição una, típica do modelo norte-americano e inglês.

3 - Até a primeira metade do século XX, havia predominância de uma concepção privatista do processo, em que a jurisdição mantinha por objetivo principal direitos subjetivos, e a afirmação da doutrina do direito processual era marcada pela construção de grandes teorias, dificultando, pois, a idealização de uma teoria processual nos outros ramos do Direito.

4 - A partir do fim do século XIX e durante a primeira metade do século XX, começa a despontar a ideia de uma processualidade ligada às três funções do Estado, o que permeou as doutrinas e estudos das décadas subsequentes até que culminou, a partir da segunda metade do século XX, em uma convergência de processualistas e administrativistas, afirmando a existência de uma esfera processual relativa à atuação dos Poderes estatais. É o momento da emergência de uma teoria geral do processo, bem como do processo administrativo. 
5 - Entre nós, o processo administrativo, no contexto da Constituição de 1988 e diante da adoção do modelo de Estado de Direito, consiste no conjunto dos atos preparatórios, cujos participantes operam em sistema de contraditório, todos direcionados ao atingimento de um ato final a ser exarado pela Administração, sendo o procedimento a técnica e a singularidade desses atos que antecedem o ato final, ou seja, processo é o conjunto e procedimento seria cada uma das diversas partes desse conjunto.

6 - No âmbito do Estado de Direito, as leis e o direito direcionam e controlam a atuação do Estado. Assim, a luta pelo Estado de Direito operou sempre no sentido de confrontar e conformar o poder estabelecido através da vontade geral, também, limitada por um direito anterior ao próprio Estado e pré-existente na sociedade.

7 - Nesse sentido, as regras e os princípios de Direito, mais propriamente aqueles princípios informativos e gerais do Direito Administrativo, bem como os cânones setoriais, peculiares ao processo administrativo, somados às normas referentes aos processos administrativos, geral e disciplinar, compõem o elenco de parâmetros de legalidade que devem reger a atividade processual da Administração.

8 - Resta claro que à Administração cabe atuação pautada pelos ditames do ordenamento jurídico em vigor, sob pena de serem considerados os respectivos atos contrários e lesivos à ordem jurídica e, portanto, passíveis de invalidação. Há que se considerar, porém, a possibilidade de diferentes hipóteses de vícios ou defeitos atingirem o ato administrativo; exsurge, pois, para a Administração, o dever de recompor a legalidade, subtraindo o ato viciado ou promovendo o saneamento.

9 - A análise dos planos de existência, da validade e da eficácia dos atos administrativos, no âmbito do Direito Administrativo, revela-se de importância ímpar, visto que a teoria dos vícios no Direito Administrativo surge justamente em face do desatendimento dos elementos, dos requisitos e dos atributos do ato administrativo. E não há que se ignorar o dever da Administração de se compatibilizar com a legalidade.

10 - Pode-se afirmar que o Direito Privado influenciou o desenvolvimento da teoria dos vícios no âmbito do Direito Administrativo, embora diversos autores ou não confirmam ou negam referida transposição.

11 - A análise dos vícios, no que concerne ao ato administrativo em um contexto isolado, pode ser transposta, em certa medida, para o ato administrativo processual. Isso porque, certamente, a investigação que deve ser realizada sobre a legalidade dos trâmites de determinado processo administrativo engloba tanto a análise pontual de cada ato 
administrativo processual, como a observação incidente sobre a íntegra do processo administrativo, após o seu término, isto é, após a decisão administrativa irrecorrível.

12 - As regras e os princípios que tratam dos vícios dos atos administrativos não pretendem reunir um elenco completo e acabado do que seria um ato administrativo viciado e de todas as suas hipóteses, até porque algumas delas podem ser imprevisíveis.

13 - Os vícios irreparáveis, que geram a nulidade absoluta, insanável, incidem sobre os elementos estruturais dos atos administrativos praticados no bojo de um processo administrativo geral, bem como no âmbito do processo administrativo disciplinar, levando à declaração da nulidade absoluta do ato administrativo processual.

14 - Diferentemente do que ocorre com os atos administrativos, em um contexto isolado, no processo administrativo, os vícios que tocam o sujeito, ou seja, os elementos competência e capacidade, bem como a forma, qualificada pela sua essencialidade, conduzem à declaração de nulidade absoluta e assim devem ser declarados de plano.

15 - No que concerne aos vícios que inquinam o objeto, o motivo e a finalidade do ato administrativo processual - aqueles que redundam em objeto ilícito, impossível ou indeterminado, onde se constata a inexistência de motivo ou a inadequação jurídica deste para o resultado concreto da ação administrativa, ou, ainda, quando se opera o denominado desvio de poder - resultarão estes na nulidade absoluta do processo administrativo atingido. Entendemos recomendável, contudo, que - concluído o processo, - se proceda a sua eventual anulação podendo-se, nesta etapa proceder à apuração da legalidade de seus trâmites e à observância ou não dos requisitos processuais exigidos para a sua validade.

16 - A operação pela qual se procede à declaração da ilegalidade no Direito Administrativo é denominada de invalidação, calcada no princípio da autotutela da Administração, cujos parâmetros estão sedimentados nas memoráveis Súmulas STF 346 e 473.

17 - Quando nos deparamos com um ato processual administrativo que contenha nulidade absoluta, em sede de processo administrativo, a regra é a declaração da nulidade com efeitos ex tunc, extirpando-se quaisquer efeitos que tenham decorrido do respectivo ato viciado, tanto jurídicos, quanto fáticos.

É possível, contudo, mesmo ante a declaração de nulidade absoluta do ato administrativo processual, que permaneçam determinados efeitos fáticos, em razão não só da impossibilidade de alteração desses efeitos, como, também, em consideração aos princípios gerais do direito, insculpidos no binômio segurança jurídica e boa-fé, elementos que, a seu 
turno, deverão ser merecedores de análise juntamente com os valores normativos decorrentes do interesse público e da legalidade.

18 - A atuação da Administração, por intermédio do princípio da autotutela, consagrado na Súmula STF $\mathrm{n}^{\mathrm{o}} 473$, com o escopo de declarar a nulidade de um ato administrativo, quer em contexto processual, quer não, deve se amoldar aos cânones condutores do standard Estado de Direito, previsto pela Constituição Federal de 1988. Esbarra, portanto, em limites ou balizas.

19- Os limites formais e materiais da declaração da ilegalidade de um ato processual, acometido pela ilegalidade, são metrificados pela necessidade de observância da garantia formal do devido processo legal, da ampla defesa e do contraditório, bem como pela perseguição da validade do novo ato processual. Este deverá se curvar a todas as regras e princípios que disciplinam o panorama do Direito Administrativo e do processo administrativo, garantindo-se uma atividade administrativa restauradora da legalidade, isenta de vícios. Uma ação válida, emanada de agente capaz e competente para tanto, com atenção às formas e formalidades essenciais, sem desvios ou ilicitudes que acometam o objeto, a finalidade e o motivo da atuação estatal reparadora.

20 - O limite temporal é qualificado pelo decurso do tempo e pela inércia da Administração em rever o ato ilegal. É dizer que não há espaço, em nosso ordenamento jurídico, conformado pelo standard do Estado de Direito, para inexistência de um prazo limite para a atuação do Estado na revisão de seus atos eivados ou não por ilegalidade. Caso assim fosse, haveria lesão à máxima da segurança jurídica e ao próprio princípio da legalidade. Daí porque parece-nos que qualquer prescrição a preconizar um tempo infinito para que se discuta um conflito - como, no caso, o interesse da Administração em anular seus atos eivados de nulidade - não deve prevalecer no tocante ao processo administrativo.

21 - No que concerne ao instituto da decadência, preconizando-se um período de tempo máximo para a Administração exercer o direito de anular seus próprios atos eivados de nulidade, parece-nos que, salvo disposição normativa expressa em contrário, por aplicação da analogia, poder-se-ia recorrer à prescrição constante do Decreto Federal $n^{0}$ 20.910/32 (prescrição em esfera judicial, com tratamento especial para a Administração), acolhendo-se o prazo de 5 (cinco) anos para anulação dos atos administrativos não eivados pela má-fé, e, de 10 (dez) anos, para os casos de atos acometidos pela má-fé do administrado. Isso, ademais, por se adotar o critério de coerência e proporcionalidade, à semelhança da solução adotada pelo Novel Código Civil. 


\section{BIBLIOGRAFIA}

ALEXY, Robert. Teoria dos Direitos Fundamentais. Tradução Virgílio Afonso da Silva. São Paulo: Melhoramentos, 2008.

ALMEIDA, Fernando Dias Menezes de. Teoria do Contrato Administrativo. Uma Abordagem Histórico-Evolutiva com Foco no Direito Brasileiro.Tese (Livre-Docência em Direito) - Faculdade de Direito da Universidade de São Paulo.

AMARAL, Antônio Carlos Cintra do. Extinção do Ato Administrativo. São Paulo: Revista dos Tribunais, 1978.

AMARAL, Diogo Freitas do. Curso de Direito Administrativo, v. 1, com a colaboração de Luís Fábrica, Carla Amado Gomes e J. Pereira da Silva. Portugal: Almedina, 2009.

ARAÚJO, Edmir Netto de. Curso de Direito Administrativo. São Paulo: Saraiva, 2010.

. Curso de Direito Administrativo. São Paulo: Saraiva, 2009.

. Curso de Direito Administrativo. São Paulo: Saraiva, 2007.

- Os princípios administrativos na Constituição de 1988. In: Revista da Procuradoria Geral do Estado, São Paulo, no 34, 1990.

. Do Negócio Jurídico Administrativo. São Paulo: Revista dos Tribunais, 1992.

. O Ilícito Administrativo e seu Processo. São Paulo: Revista dos Tribunais, 1994.

. Curso de Direito Administrativo. São Paulo: Saraiva, 2005.

. A convalidação dos atos administrativos e as leis de processo administrativo. In: NOHARA, Irene Patrícia; MORAES FILHO, Marco Antônio Praxedes de (Orgs.). Processo Administrativo. Temas Polêmicos da Lei 9.784/99. São Paulo: Atlas, 2011. p. 43-66.

. Convalidação do ato administrativo. São Paulo: Editora Ltr, 1999.

AZEVEDO, Antônio Junqueira de. Negócio Jurídico. Existência, validade e eficácia. São Paulo: Saraiva, 1986

BANDEIRA DE MELLO, Celso Antônio. Ato Administrativo e Direito dos Administrados. São Paulo: RT, 1981.

. Elementos de Direito Administrativo. São Paulo: Revista dos Tribunais, 1980.

. Elementos de Direito Administrativo. São Paulo: Malheiros, 1992.

. Curso de Direito Administrativo. São Paulo: Malheiros, 1999. 
. Curso de Direito Administrativo. São Paulo: Malheiros, 2000.

. Curso de Direito Administrativo. 29. ed. São Paulo: Malheiros, 2012.

. Discricionariedade e Controle Jurisdicional. São Paulo: Malheiros, 2007

BANDEIRA DE MELlO, Oswaldo Aranha. Princípios Gerais de Direito Administrativo, Rio de Janeiro: Forense, 1979. (v. 1 e 2).

BARRos, Marco Antonio de. A Busca da Verdade no Processo Penal. São Paulo: Revista dos Tribunais, 2002.

BEDAQUE, José Roberto dos Santos. Poderes Instrutórios do Juiz. São Paulo: Revista dos Tribunais, 2001.

BENVENUTTI, Feliciano. Função Administrativa, Procedimento e Processo. In: Rivista Trimestrale di Diritto Pubblico, 1952.

BITTAR, Eduardo C. B. Metodologia da pesquisa jurídica. São Paulo: Saraiva, 2001.

BRANDÃO CAVALCANTI, Themístocles. A codificação do processo administrativo. Direito, Rio, v. I, n. 1, jan-fev. 1940.

. Código do processo administrativo. In: Revista do Serviço Público, n. 3, 1938.

1956.

. Tratado de Direito Administrativo. v. IV. 3. ed. Rio de Janeiro: Freitas Bastos, . Direito e Processo Disciplinar. Rio de Janeiro: Fundação Getúlio Vargas, 1966.

BUARQUE DE HOLANDA FERREIRA, Aurélio. Novo Dicionário Aurélio. Rio de Janeiro: Nova Fronteira, 2001.

BUENO, Vera Scarpinella. Devido Processo Legal e a Administração Pública no Direito Administrativo Norte-Americano. Uma breve comparação com o brasileiro. p. 18-19. In: FIGUEIREDO, Lucia Valle (Coord). Devido Processo Legal na Administração Pública. São Paulo: Max Limonad, 2001.

BURDEAU, Georges. Les Libertés Publiques. Paris: Librairie Généralle de Droit et Jurisprudence, 1972.

CAEtAnO, Marcello. Do Poder Disciplinar no Direito Administrativo Português. Coimbra: Imprensa da Universidade, 1932.

. Manual de Direito Administrativo. Coimbra: Livraria Almedina, 1983. (tomo II).

. Manual de Direito Administrativo. v. 1. Lisboa, Portugal: Almedina, 2008.

. Tratado elementar de Direito Administrativo. Vol. I. Coimbra: Ed. Coimbra, 1943 
CÂMARA, Jacinto de Arruda. A preservação dos efeitos dos atos administrativos viciados. In: Estudos de Direito Administrativo em homenagem ao Prof. Celso Antônio Bandeira de Mello. São Paulo: Max Limonad, 1996.

CANOtilho, J. J. Gomes. Direito Constitucional e Teoria da Constituição. 4. ed. Coimbra, Portugal: Almedina.

Direito Constitucional. Coimbra, Portugal: Almedina, 1989.

CARNElUTTI, Francesco. Sistema di Diritto Processuale Civile. Padova: Cedam, 1936. (vol. 1).

CARVALHO FILHO, José dos Santos. Direito Administrativo. Rio de Janeiro: Lumen Juris, 2000.

. O formalismo moderado como dogma do processo administrativo. p. 109. In: NOHARA, Irene Patrícia; MORAES FILHO, Marco Antônio Praxedes de (Orgs.). Processo Administrativo. Temas Polêmicos da Lei 9.784/99. São Paulo: Atlas, 2011. p. 101-120

CASTRO, Carlos Roberto de Siqueira. O Devido Processo Legal e a Razoabilidade das Leis na Nova Constituição do Brasil. Rio de Janeiro: Forense, 1989.

CHEVALLIER, Jacques. L'etat de droit. Paris: Montchrestien, 1992.

CINTRA, Antonio Carlos de Araújo; GRINOVER, Ada Pellegrini; DINAMARCO, Cândido R. Teoria Geral do Processo. São Paulo: Revista dos Tribunais, 2000.

. Teoria Geral do Processo. 27. ed. São Paulo: Malheiros, 2011.

COSTA, José Armando da. Teoria e Prática do Processo Administrativo Disciplinar. São Paulo: Saraiva, 1984.

CRETELLA JÚNIOR, José. Tratado de Direito Administrativo. Rio de Janeiro: Forense, 1969. (v. 6).

. Direito Administrativo Comparado. São Paulo: José Bushatsky Editor, 1972.

. Direito Administrativo Brasileiro. Rio de Janeiro: Forense, 1983. (v. 1).

. Curso de Direito Administrativo. 17. ed. Rio de Janeiro: Forense, 2000.

1978.

. Anulação do Ato Administrativo por desvio de poder. Rio de Janeiro: Forense,

. Manual de Direito Administrativo. Rio de Janeiro: Forense, 1989.

. Tratado de Direito Administrativo. vol II. São Paulo: Forense, 1966

. Controle Jurisdicional do Ato Administrativo. São Paulo: Forense, 1992. 
. Do desvio de poder. São Paulo: RT, 1964;

. Sintomas denunciadores do desvio de poder. In: Revista da Procuradoria Geral do Estado. São Paulo. vol. 9, 1976.

CRETELLA NETO, José. Fundamentos principiológicos do processo civil. Rio de Janeiro: Forense, 2002.

D’ALESSIO, Francesco. Diritto Amministrativo Italiano. Torino: Unione TipográficoEditrice Torinese, 1943. (v. 2).

DAVID, René. I Grandi Sistemi Giuridici Contemporanei. Padova: CEDAM, Casa Editrice Dott. Antonio Milani, 1973.

DINAMARCO, Cândido R. Fundamentos do Processo Civil Moderno. São Paulo: Revista dos Tribunais, 1985.

. A Instrumentalidade do Processo. São Paulo: Revista dos Tribunais, 1986.

DI PIETRO, Maria Sylvia Zanella. Do Direito Privado na Administração Pública. São Paulo: Atlas, 1989.

. Direito Administrativo. São Paulo: Atlas, 2012.

. Direito Administrativo. São Paulo: Atlas, 2006.

. Direito Administrativo. São Paulo: Atlas, 1994.

. Parcerias na Administração Pública. São Paulo: Atlas, 1996.

. Parcerias na Administração Pública. São Paulo: Atlas, 1999.

DI PIETRO, Maria Sylvia Zanella; RAMOS, Dora Maria de Oliveira; SANTOS, Márcia Walquíria Batista dos; D’AVILA, Vera Lúcia Machado. Temas Polêmicos sobre Licitações e Contratos. São Paulo: Malheiros, 2001.

DUVERGER, Maurice. Constitutions et Documents Politiques. Paris: Presses Universitaire de France, 1974.

EISENMANN, Charles. O Direito Administrativo e o Princípio da Legalidade. Revista de Direito Administrativo, abril - junho de 1959, vol. 56, p. 49-69 (Traduzido da revista "Études et Documents", Conseil d'Etat, fasc. 11, p. 25 e ss., por Ruth Barbosa Goulart, advogada no Rio de Janeiro).

FAGUNDES, Miguel Seabra. O controle dos atos administrativos pelo Poder Judiciário. Rio de Janeiro: Freitas Bastos, 1941.

FERRARI, Regina Maria Macedo Nery. A Constitucionalização do Direito Administrativo e as Políticas Públicas. In: RIBEIRO, Lauro Luiz Gomes; BERARDI, Luciana Andrea Accorsi 
(Orgs.). Estudos de Direito Constitucional, em homenagem à Profa. Maria Garcia. organizadores. 2. ed. São Paulo: IOB, 2008.

FERRAZ, Sérgio; DALLARI, Adilson Abreu. Processo Administrativo. São Paulo: Malheiros, 2001.

FERREIRA FILHO, Manoel Gonçalves. Curso de Direito Constitucional. 32. ed. São Paulo: Saraiva, 2006.

. Curso de Direito Constitucional. São Paulo: Saraiva, 2008.

2009.

. Princípios Fundamentais do Direito Constitucional. 2. ed. São Paulo: Saraiva, . Do processo Legislativo, São Paulo: Saraiva, 1968.

FIGUEIREDO; Lucia Valle. Curso de Direito Administrativo. São Paulo: Malheiros, 2001. . Curso de Direito Administrativo. 8. ed. São Paulo: Malheiros, 2006.

FORSTHOFF, Ernst. Stato di Diritto in Trasformazione. Milano: Giuffré Editore, 1973.

FRAGOLA, Umberto. Gli atti amministrativ. Torino: UTET, 1952.

FRANCO, Fernão Borba. Processo Administrativo. São Paulo: Atlas, 2008.

FRANCO SOBRINHO, Manoel de Oliveira. A Prova Administrativa. São Paulo: Saraiva, 1973.

GASPARINI, Diógenes. Direito Administrativo. São Paulo: Saraiva, 2002.

. Direito Administrativo. São Paulo: Saraiva, 2008.

GRINOVER, Ada Pellegrini. O Processo em Evolução. Rio de Janeiro: Forense Universitária, 1998.

- A Marcha do Processo. Rio de Janeiro: Forense Universitária, 2000.

. As Garantias Constitucionais do Direito de Ação. São Paulo: RT, 1973.

. Garantias do contraditório e ampla defesa. In: Jornal do Advogado, Seção de São Paulo, n. 175, p. 9, nov.1990 .

. Novas Tendências do Direito Processual. Rio de Janeiro: Forense Universitária, 1990.

GUALAZZI, Eduardo Lobo Botelho. Ato Administrativo Inexistente. São Paulo: RT, 1980.

GUSMÃO, Paulo Dourado de. Introdução à Ciência do Direito. Rio de Janeiro: Forense, 1960. 
HAURIOU, Maurice. Précis de Droit Administratif et de Droit publique. 12. ed. (reimpressão da edição de 1933). 2002.

HORBACH, Carlos Bastide. Teoria das nulidades do ato administrativo. 2. ed. São Paulo: RT, 2010.

HORTA, Raul Machado. Direito Constitucional. 5. ed. Belo Horizonte: Del Rey, 2010.

JÈZE, Gaston. Les principes géneraux Du Droit Administratif. 3.ed. Paris: Ed. Giard e Briére, 1925 a 1936.

KELSEN, Hans. Teoria Pura do Direito. 2. ed. São Paulo: Martins Fontes, 1987.

LAUBADÈRE, André de. Traité Élémentaire de droit administratif. Paris, 1953.

LIEBMAN, Enrico Tullio. Manuale di Diritto Processuale Civile. Milano: Dott. A. Giuffrè Editore, 1973. (v. 1).

LIMA, Ruy Cirne. Princípios de direito administrativo. 6. ed. São Paulo: RT, 1987.

LOMBARD, Martine ; DUMONT, Gilles. Droit Administratif. 8. ed. Paris: Dalloz.

LOSANO, Mário G. Os Grandes Sistemas Jurídicos. Tradução Marcela Varejão. São Paulo: Martins Fontes, 2007.

MALBERG, R. Carré de. Teoría General Del Estado. México: Fondo de Cultura Economica, 1998.

MASAGÃO, Mário. Curso de Direito Administrativo. São Paulo: Revista dos Tribunais, 1977.

MAZZA, Alexandre. Manual de Direito Administrativo. 2. ed. São Paulo: RT: 2012.

MEDAUAR, Odete. A Processualidade no Direito Administrativo. São Paulo: Revista dos Tribunais, 2008.

. Direito Administrativo Moderno. São Paulo: RT, 2011.

. Direito Administrativo Moderno. São Paulo: RT, 2007.

. Controle da Administração Pública. São Paulo: RT, 1993.

O princípio da razoável duração do processo. In: MEDAUAR, Odete; SCHIRATO, Vitor Rhein (Orgs.). Atuais rumos do processo administrativo. São Paulo: Revista dos Tribunais, 2010.

MEIRELLES, Hely Lopes. Direito Administrativo Brasileiro. São Paulo: RT, 1978.

. Direito Administrativo Brasileiro. 33. ed. São Paulo: RT, 2007. 
. Direito Administrativo Brasileiro. São Paulo: Malheiros, 2004.

MENDES, Gilmar Ferreira; COELHO, Inocêncio Mártires; BRANCO, Paulo Gustavo Gonet. Curso de Direito Constitucional. 2. ed. São Paulo: Saraiva, 2008.

MERKL, Adolf. Teoria General del Derecho Administrativo. México: Nacional, 1975.

MONTESQUIEU, Charles-Louis de Secondat, Barão de la Brède et de. Do Espírito das Leis. Tradução de Fernando Henrique Cardoso e Leôncio Martins Rodrigues. São Paulo: Difusão Europeia do Livro.

MOREIRA, Egon Bockmann. Processo Administrativo - Princípios Constitucionais e a Lei 9.784/1999. São Paulo: Malheiros, 2003.

MOREIRA NETO, Diogo de Figueiredo. Curso de Direito Administrativo. Rio de Janeiro: Forense, 1989.

. Curso de Direito Administrativo. Rio de Janeiro: Forense, 2005. Capítulo VIII,

NERY JUNIOR, Nelson. Princípios do Processo na Constituição Federal, Processo civil, penal e administrativo. São Paulo: RT, 2009.

NEVADO-BATAlLA MORENO, Pedro T. Notas sobre Derecho Administrativo II, Salamanca, Espanha: Ratio Legis Librería Jurídica, 2002.

OLIVEIRA, Regis Fernandes de. Ato Administrativo. São Paulo: RT, 2001. . Ato administrativo. São Paulo: RT, 1978.

PASTOR, Juan Alfonso Santamaría. Princípios de Derecho Administrativo. 3. ed. Madri: Coleccion Ceura, Editorial Centro de Estudios Ramón Areces, S/A.

PONTES DE MIRANDA. F. C. Os fundamentos Atuais do Direito Constitucional. Rio de Janeiro: Empresa de Publicações Técnicas 1932.

. Tratado de Direito Privado. t. IV. Rio de Janeiro: Borsói, 1954.

REALE, Miguel. Filosofia do Direito. São Paulo: Saraiva, 1975. (v. 1 e 2). 285/194-197.

Teoria do Conhecimento e Teoria da Cultura. In: Revista Brasileira de Filosofia

RIBAS, Antônio Joaquim. Direito Administrativo Brasileiro. S.1. Brasília: Ministério da Justiça, 1968.

RIVERO, Jean. Curso de Direito Administrativo Comparado. Tradução J. Cretella Jr.. São Paulo: Revista dos Tribunais, 1995.

ROJO, Margarita Beladiez. Validez Y Eficacia de los Actos Administrativos. Madrid: Marcial Pons Ediciones Juridicas S.A, 1994. 
ROUSSEAU, Jean-Jacques. O Contrato Social e outros escritos. São Paulo: Cultrix, 1975.

SAMPAIO DÓRIA, Antônio Roberto. Princípios Constitucionais Tributários e a Cláusula "Due Process of Law. São Paulo: RT, 1964.

SANTIAGO DANTAS, F. C. de. Igualdade perante a lei e due process of law. Problemas de Direito Positivo. Rio de Janeiro: Forense, 1986. SCHIESARI, Nelson. Direito Administrativo. São Paulo: Saraiva, 1982.

SCHMITT, Carl. Teoria de la Constitución. México: Editora Nacional.

SEIXAS, Therezinha da Silva. Metodologia do Trabalho Jurídico-Científico. São Bernardo do Campo, São Paulo: Assahi, 2008.

SILVA, José Afonso da. Curso de Direito Constitucional Positivo. São Paulo: Malheiros, 2004. . Curso de Direito Constitucional Positivo. São Paulo: RT, 1989

SIMÕES, Mônica Martins Toscano. O Processo Administrativo e a Invalidação de Atos Viciados. São Paulo: Malheiros, 2004.

SOARES, Guido Fernando Silva. Common Law: Introdução ao Direito dos EUA. São Paulo: Revista dos Tribunais, 1999.

SUNDFELD, Carlos Ari; MUÑOZ, Guillermo Andrés (coord.). As Leis do Processo Administrativo. São Paulo: Malheiros, 2000.

. Ato Administrativo Inválido. São Paulo: Revista dos Tribunais, 1990.

TÁCITO, Caio. Previdência Privada - Desvio de poder e ato legislativo. In: $R D P$, n. 100, outdez/1991, ano 25, ISSN 0034-8015.

TOURINHO FILHO, Fernando da Costa. Processo Penal. São Paulo: Saraiva, 2003. (v.1).

TRUJILLO, Elcio. Responsabilidade do Estado por Ato Lícito. São Paulo: Editora de Direito, 1996.

TUCCI, Rogério Lauria. Lineamentos do Processo Penal Romano. São Paulo: Bushatsky, 1976.

URUGUAI, Paulino José Soares de Souza, Visconde do. Ensaio sobre o Direito Administrativo. Brasília: Ministério da Justiça, 1997.

VILLAR Y ROMERO, José María. Derecho Procesal Administrativo. Madri: Editorial Revista de Derecho Privado, 1944.

WALINE, Marcel. Droit Administratif. Paris: Lib. Rec. Sirey, 1963. 
ZAGO, Lívia Maria Armentano Koenigstein. O Princípio da Impessoalidade. Rio de Janeiro: Renovar, 2001.

ZANCANER, Weida. Da Convalidação e da Invalidação dos Atos Administrativos. São Paulo: Revista dos Tribunais, 1990.

ZANOBINI, Guido. L'ATTIVITÀ AMMINISTRATIVA E LA LEGGE. In: Revista de Direito Público. Milão, Itália: Editora Dott A. Giuffrè, 1955. p. 204-208.

ZIPPELIUS, Reinhold. Teoria Geral do Estado. Tradução Antônio Cabral de Moncada. 2.ed. Lisboa: Fundação Calouste Gulbenkian, 1971. 